\title{
AVALIAÇÃO DAS CONSEQÜÊNCIAS DA "LEÍ DOS AGROTÓXICOS" NAS INTOXICAÇÕES E NAS CLASSIFICAÇÕES TOXICOLÓGICA E DE POTENCIAL DE PERICULOSIDADE AMBIENTAL NO PERÍODO DE 1990 A 2000
}

EDUARDO GARCIA GARCIA

Tese de Doutorado apresentada ao Departamento de Saúde Ambiental da Faculdade de Saúde Pública da Universidade de São Paulo para obtenção do Grau de Doutor.

Área de concentração:

Saúde Ambiental

ORIENTADOR:

PROF. TITULAR FRIDA MARINA FISCHER

São Paulo 
Dedico às minhas pequenas, Nina e Lara, grande motivação da minha vida. 


\section{AGRADECIMENTOS}

À Prof. Titular Frida Marina Fischer, pela orientação segura e pelo estímulo para a realização deste trabalho.

Aos Drs. Alberto José Centeno, Angelo Zanaga Trapé, Clayton Campanhola e Helena Ribeiro, pelas valiosas sugestões para o aprimoramento deste estudo.

Ao Estatístico Marco Antonio Bussacos, pelas sugestões, orientação e colaboração nas análises estatísticas.

Aos Engenheiros Agrônomos José Prado Alves Filho e Rosa Yasuko Yamashita, por possibilitarem maior dedicação a este trabalho.

Ao Comitê de Pós-graduação da FUNDACENTRO, pela compreensão quanto à necessidade de estender o prazo para a conclusão deste estudo.

À FUNDACENTRO, por proporcionar a oportunidade e o apoio institucional para cursar a pós-graduação.

À minha família, pelo apoio, paciência, compreensão e colaboração durante os meus períodos de dedicação a este trabalho.

A todos que de alguma forma contribuíram para a realização deste projeto. 


\section{RESUMO}

Garcia EG. Avaliação das conseqüências da "Lei dos Agrotóxicos" nas intoxicações e nas classificações toxicológica e de potencial de periculosidade ambiental no período de 1990 a 2000. São Paulo; 2001. [Tese de Doutorado Faculdade de Saúde Pública da Universidade de São Paulo].

Objetivo. A Lei 7802/89 (Lei dos Agrotóxicos) foi considerada importante avanço para enfrentar problemas ambientais e de saúde provocados por agrotóxicos. Este estudo buscou avaliar o impacto da Lei e respectiva regulamentação na classificação toxicológica, na classificação de potencial de periculosidade ambiental dos agrotóxicos e nas intoxicações registradas. Métodos. Analisou-se a correlação entre vendas de agrotóxicos e registros de intoxicações no Brasil, de 1985 a 1999, utilizando Coeficiente de Correlação Linear de Pearson e Análise de Regressão. Os testes Qui-Quadrado de Tendência em Dados Ordenáveis e Coeficiente de Kappa foram utilizados para comparar o conjunto de substâncias que estava registrado em 1990 com o que estava registrado em 2000, segundo a classificação de periculosidade da Organização Mundial da Saúde. Analisaram-se as culturas/produtos de destinação permitidas, a classificação toxicológica e a de periculosidade ambiental dos produtos registrados após a Lei. Resultados. A correlação entre vendas e intoxicações foi positiva $(r=0,82 ; \mathrm{p}<0,0001)$. Obteve-se equação intox $=0,00236 \times$ vendas (US\$ 1,000.00) que permite estimar intoxicações registradas segundo vendas de agrotóxicos $\left(R^{2}=0,95 ; F=253,48\right.$; $\mathrm{p}<0,0001)$. Não houve diferenças significativas na classificação toxicológica e ambiental dos conjuntos de substâncias registradas antes-depois da Lei. Os registros posteriores à Lei continuaram privilegiando culturas de maior expressão econômica e agrotóxicos derivados de substâncias registradas antes da Lei. Produtos mais tóxicos foram registrados para finalidade que contava com outros menos tóxicos. Conclusões. Após dez anos não se consolidaram avanços esperados com a Lei. Recomendou-se: aplicar legislação com maior eficácia, priorizar registros de menor impacto, restringir produtos de maior periculosidade.

Descritores: Agrotóxicos. Intoxicações. Toxicologia. Ambiente. Legislação. Segurança Química. 


\section{SUMMARY}

Garcia EG. Avaliação das conseqüências da “Lei dos Agrotóxicos" nas intoxicações e nas classificações toxicológica e de potencial de periculosidade ambiental no período de 1990 a 2000. [Evaluation of the "Pesticide Law" consequences on intoxications and on toxicological and environmental potential hazard classifications from 1990 to 2000]. São Paulo; 2001. [Tese de Doutorado Faculdade de Saúde Pública da Universidade de São Paulo].

Objective. The 1989 Brazilian's pesticide legislation (Law $\mathrm{n}^{\circ}$ 7802/89) was considered an important improvement to control environmental and health problems. This study aimed to evaluate the impact of the law and it's regulations to the toxicological and environmental classifications of pesticides by hazard and to the notified poisonings. Methods. Pearson Correlation and Regression Analysis were used to evaluate the correlation between pesticide sales and notified intoxications in Brazil, from 1985 to 1999. Kappa Coefficient and Ridit Analysis (Relative Identified Distribution Analysis) were used to compare the WHO (World Health Organization) classification of pesticides by hazard of the group of chemicals that was registered in 1990 and the group registered in 2000. The toxicological and environmental classifications and the allowed destinations of the pesticides that were registered after the law were also analyzed. Results. The correlation among sales of pesticides and poisonings was positive $(r=0,82 ; p<0,0001)$. The equation obtained make possible to estimate poisonings notifications using values of pesticides sales $\left(R^{2}=0,95\right.$; $F=253,48 ; p<0,0001):$ intox $=0,00236 \times$ sales (US\$ 1,000.00) . No significant toxicological and environmental classifications differences were identified between the groups of pesticides that were registered in 1990 and 2000. The most economical expressive crops received the majority of the registers. More toxic pesticides were registered to destinations that had less toxic ones. Conclusions. After ten years of Law it was not possible to consolidate the expected improvements. Recommendations included: enforcement of the law, priority to less risky pesticides, restriction to more toxic ones.

Descriptors: Pesticides. Poisonings. Toxicology. Environment. Legislation. Chemical Safety. 


\section{ÍNDICE}

1. INTRODUÇÃO

1.1. A motivação, as limitações e a relevância do trabalho .................................. 1

1.2. Agrotóxicos: uso e impactos ..................................................................... 4

1.3. A proposição da "Lei dos Agrotóxicos" .......................................................... 6

1.4. Os avanços da "Lei dos Agrotóxicos" ......................................................... 8

1.5. A regulamentação da "Lei dos Agrotóxicos".................................................. 9

1.5.1. A regulamentação básica........................................................................ 9

1.5.2. A regulamentação relacionada à área da agricultura.............................. 12

1.5.3. A regulamentação relacionada à área ambiental .................................... 13

1.5.4. A regulamentação relacionada à área da saúde..................................... 14

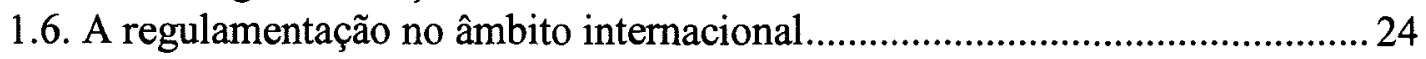

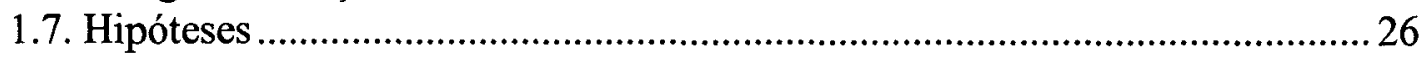

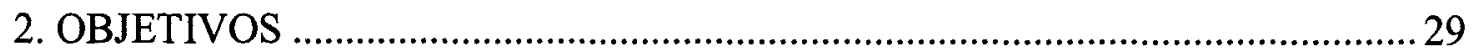

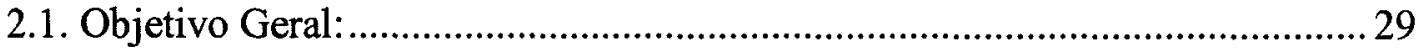

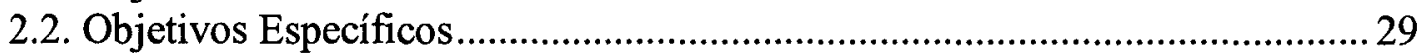

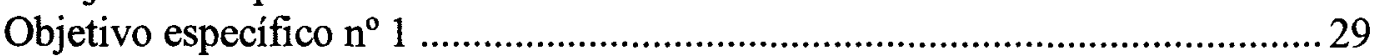

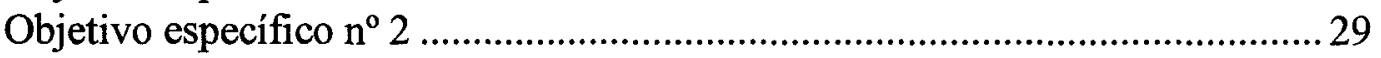

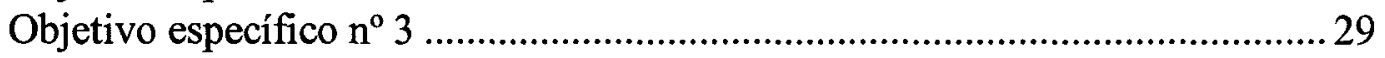

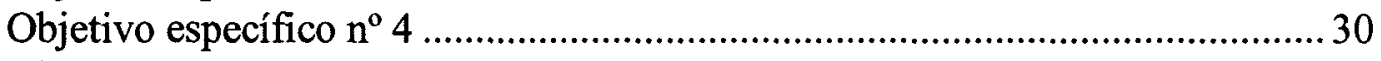

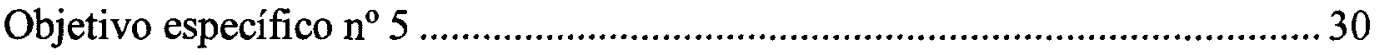

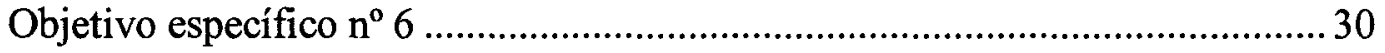

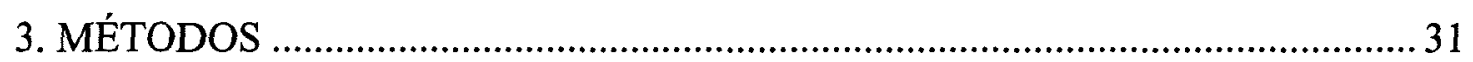

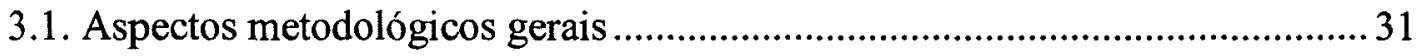

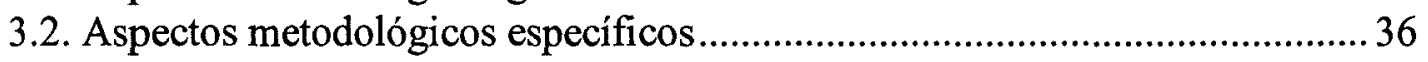

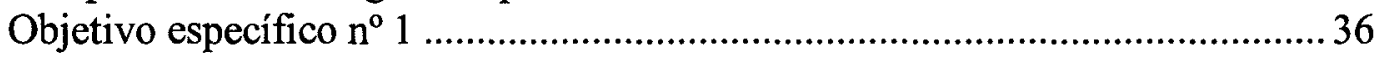

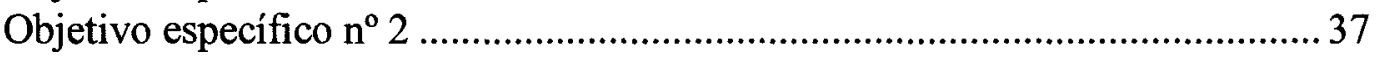

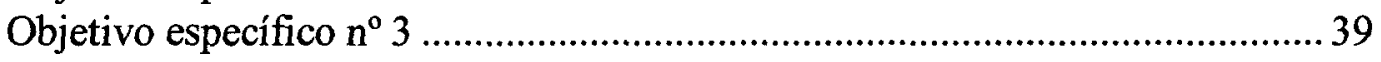

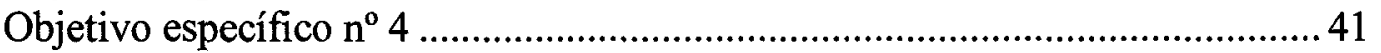

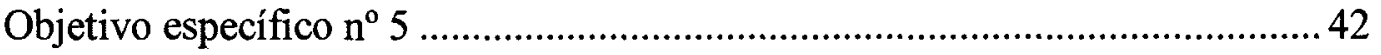

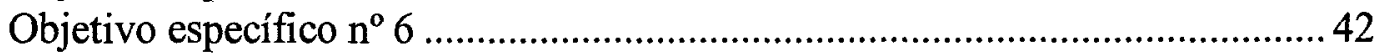

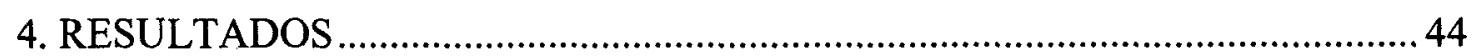

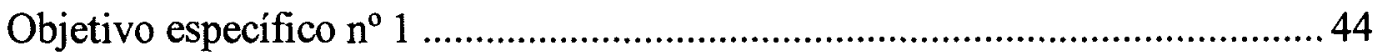

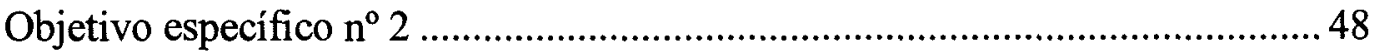

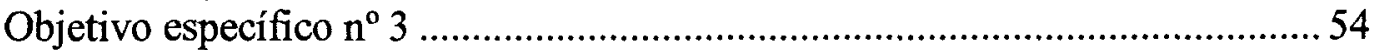

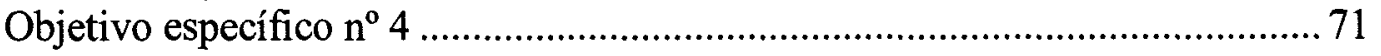

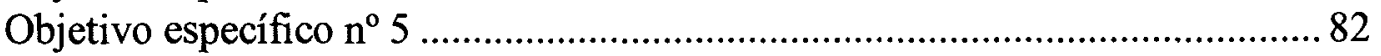

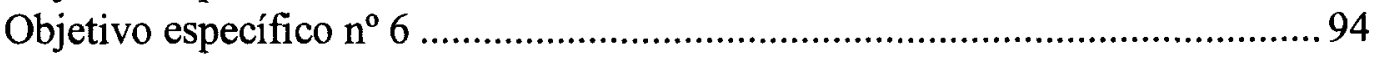

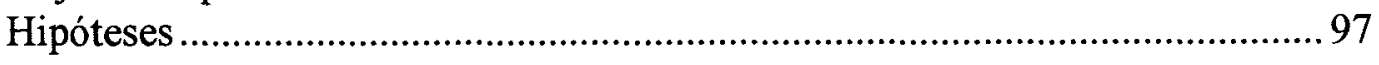


5. DISCUSSÃO

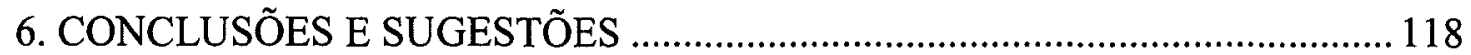

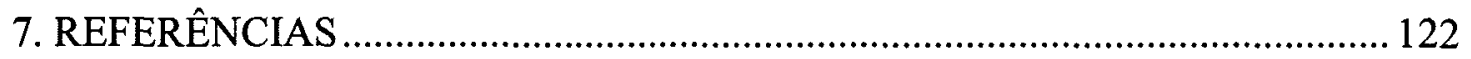

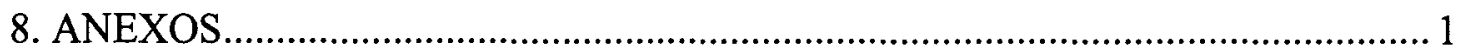

ANEXO 1 - banco de dados $\mathrm{n}^{\mathrm{o}} 1$ - Ingrediente Ativo ..............................................

ANEXO 2 - banco de dados $n^{\circ} 2$ - Produtos Comerciais...................................... 12

ANEXO 3 - banco de dados $\mathrm{n}^{\circ} 4$ - Classificação Toxicológica .................................. 39

ANEXO 4 - banco de dados n 5 - produtos registrados para controle do "pulgão do algodoeiro" (Aphis gossypii) ......................................................................... 54

\section{ÍNDICE DE FIGURAS}

Figura 1 - Comparação entre as faixas de classificação toxicológica das Portarias DISAD n $n^{\circ} 4 / 80\left(^{*}\right)$ e SNVS $n^{\circ} 3 / 92(* *)$, para formulações líquidas.

Figura 2 - Comparação entre as faixas de classificação toxicológica das Portarias $\operatorname{DISAD~n}^{\circ} 4 / 80\left(^{*}\right)$ e SNVS n ${ }^{\circ}$ 3/92 (**), para formulações sólidas.

Figura 3 - Vendas de agrotóxicos e casos de intoxicações por pesticidas agropecuários registrados pelo SINITOX*, no Brasil, no período de 1985 a 1999.

Figura 4 - Diagrama de dispersão das vendas de agrotóxicos e casos de intoxicações por pesticidas agropecuários, no Brasil, no período de 1985 a 1999................... 46

Figura 5 - Reta de regressão e respectivos intervalos de confiança definidos a partir das vendas de agrotóxicos e casos de intoxicações por pesticidas agropecuários, no Brasil, no período de 1985 a 1999.

Figura 6 - Proporções de Produtos Comerciais registrados após a "Lei dos Agrotóxicos" (Lei 7802/89) nas Classes Toxicológicas I e II, segundo a Classe de Uso e a época de registro do Ingrediente Ativo. 


\section{ÍNDICE DE TABELAS}

Tabela 1 - Classes de Potencial de Periculosidade Ambiental

Tabela 2 - Classificação de agrotóxicos segundo a periculosidade*, recomendada pela Organização Mundial da Saúde - OMS

Tabela 3 - Parâmetros referentes à $\mathrm{DL}_{50}$ estabelecidos para a classificação toxicológica de agrotóxicos pela Portaria DISAD n 4, de 30 de abril de 1980.

Tabela 4 - Parâmetros referentes à $\mathrm{DL}_{50}$ estabelecidos para a classificação toxicológica de agrotóxicos pela Portaria SNVS n ${ }^{\circ} 3$, de 16 de janeiro de 1992, regulamentando a "Lei dos Agrotóxicos" (Lei 7802/89).

Tabela 5 - Critérios referentes à $\mathrm{CL}_{50}{ }^{*}$, lesões oculares e lesões dérmicas estabelecidos para a classificação toxicológica de agrotóxicos pela Portaria SNVS n ${ }^{\circ} 3$, de 16 de janeiro de 1992, regulamentando a "Lei dos Agrotóxicos" (Lei 7802/89).

Tabela 6 - Denominação das Classes Toxicológicas.

Tabela 7 - Distribuição comparada da classificação toxicológica* dos Produtos Comerciais que estavam registrados em 1990, segundo as Classes Toxicológicas definidas pela Portaria 4/80 e pela Portaria 3/92.

Tabela 8 - Distribuição da classificação toxicológica* dos Produtos Comerciais que estavam registrados em 1990, segundo a concordância entre as Classes Toxicológicas definidas pela Portaria 4/80 e pela Portaria 3/92.

Tabela 9 - Distribuição comparada da classificação toxicológica* dos Produtos Comerciais com formulações líquidas que estavam registrados em 1990, segundo as Classes Toxicológicas definidas pela Portaria 4/80 e pela Portaria $3 / 92$.

Tabela 10 - Distribuição da classificação toxicológica* dos Produtos Comerciais com formulações líquidas que estavam registrados em 1990, segundo a concordância entre as Classes Toxicológicas definidas pela Portaria 4/80 e pela Portaria 3/92.

Tabela 11 - Distribuição comparada da classificação toxicológica* dos Produtos Comerciais com formulações sólidas que estavam registrados em 1990, segundo as Classes Toxicológicas definidas pela Portaria 4/80 e pela Portaria 3/92. .....52 
Tabela 12 - Distribuição da classificação toxicológica* dos Produtos Comerciais com formulações sólidas que estavam registrados em 1990, segundo a concordância entre as Classes Toxicológicas definidas pela Portaria 4/80 e pela Portaria 3/92.

Tabela 13 - Distribuição dos Ingredientes Ativos que estavam registrados em 1990, dos que foram registrados após a "Lei dos Agrotóxicos" (Lei 7802/89) e dos que estavam registrados em 2000, segundo a Classe de Uso e o aumento relativo de registros ocorrido no período.

Tabela 14 - Ingredientes Ativos que estavam registrados em 1990 e 2000, segundo a classe de periculosidade da OMS e a eliminação, reclassificação ou entrada de novos registros no período.

Tabela 15 - Distribuição dos Ingredientes Ativos classificados pela OMS que estavam registrados em 1990, dos que foram registrados após a "Lei dos Agrotóxicos" (Lei 7802/89) e dos que estavam registrados em 2000, segundo a Classe de Periculosidade definida pela Organização Mundial da Saúde - OMS.

Tabela 16 - Ingredientes Ativos de inseticidas* que estavam registrados em 1990 e 2000, segundo a classe de periculosidade da Organização Mundial da Saúde OMS e a eliminação, reclassificação ou entrada de novos registros no período.

Tabela 17 - Distribuição dos Ingredientes Ativos de inseticidas* que foram registrados antes da "Lei dos Agrotóxicos" (Lei 7802/89) e estavam registrados em 1990, dos que foram registrados após a Lei e dos que estavam registrados em 2000, segundo a Classe de Periculosidade definida pela Organização Mundial da Saúde - OMS.

Tabela 18 - Ingredientes Ativos de fungicidas* que estavam registrados em 1990 e 2000, segundo a classe de periculosidade da OMS e a eliminação, reclassificação ou entrada de novos registros no período.

Tabela 19 - Distribuição dos Ingredientes Ativos de fungicidas* que foram registrados antes da "Lei dos Agrotóxicos" (Lei 7802/89) e estavam registrados em 1990, dos que foram registrados após a Lei e dos que estavam registrados em 2000, segundo a Classe de Periculosidade definida pela Organização Mundial da Saúde - OMS.

Tabela 20 - Ingredientes Ativos de herbicidas* que estavam registrados em $1990 \mathrm{e}$ 2000, segundo a classe de periculosidade da OMS e a eliminação, reclassificação ou entrada de novos registros no período. 
Tabela 21 - Distribuição dos Ingredientes Ativos de herbicidas* que foram registrados antes da "Lei dos Agrotóxicos" (Lei 7802/89) e estavam registrados em 1990, dos que foram registrados após a Lei e dos que estavam registrados em 2000, segundo a Classe de Periculosidade definida pela Organização Mundial da Saúde - OMS.

Tabela 22 - Ingredientes Ativos da Classe de Uso "outros"* que estavam registrados em 1990 e 2000, segundo a classe de periculosidade da OMS e a eliminação, reclassificação ou entrada de novos registros no período.

Tabela 23 - Distribuição de Ingredientes Ativos que estavam registrados em 2000*, segundo a Classe Toxicológica informada pelo Ministério da Saúde (MS) e a correspondente Classe de Periculosidade informada pela Organização Mundial da Saúde (OMS).

Tabela 24 - Distribuição comparativa dos Ingredientes Ativos que estavam registrados em 2000*, segundo a Classe Toxicológica informada pelo Ministério da Saúde (MS) e a correspondente Classe de Periculosidade informada pela Organização Mundial da Saúde (OMS).

Tabela 25 - Distribuição dos Ingredientes Ativos registrados posteriormente à "Lei dos Agrotóxicos" (Lei 7802/89), segundo a Classe de Uso e a Classe de Periculosidade definida pela Organização Mundial da Saúde - OMS.

Tabela 26 - Distribuição dos Ingredientes Ativos registrados posteriormente à "Lei dos Agrotóxicos" (Lei 7802/89), segundo a Classe de Uso e a Classe Toxicológica definida pelo Ministério da Saúde.

Tabela 27 - Distribuição dos Ingredientes Ativos* que foram registrados após a "Lei dos Agrotóxicos" (Lei 7802/89), segundo a Classe Toxicológica informada pelo Ministério da Saúde (MS) e a correspondente Classe de Periculosidade informada pela Organização Mundial da Saúde (OMS).

Tabela 28 - Distribuição comparativa dos Ingredientes Ativos* registrados posteriormente à "Lei dos Agrotóxicos" (Lei 7802/89), segundo a Classe Toxicológica informada pelo Ministério da Saúde (MS) e a correspondente Classe de Periculosidade informada pela Organização Mundial da Saúde (OMS).

Tabela 29 - Distribuição dos Produtos Comerciais que estavam registrados em 1990, dos que foram registrados após a "Lei dos Agrotóxicos" (Lei 7802/89) e dos que estavam registrados em 2000, segundo a Classe de Uso e o aumento relativo no número de produtos registrados no período.

Tabela 30 - Distribuição dos Produtos Comerciais que se encontravam registrados em 2000, segundo a Classe de Uso e a época de registro dos seus Ingredientes Ativos. 
Tabela 31 - Distribuição dos Produtos Comerciais registrados posteriormente à "Lei dos Agrotóxicos" (Lei 7802/89), segundo Classe de Uso e a Classe Toxicológica definida pelo Ministério da Saúde.

Tabela 32 - Distribuição dos Produtos Comerciais registrados posteriormente à "Lei dos Agrotóxicos" (Lei 7802/89), segundo a Classe de Uso e a Classe de Potencial de Periculosidade Ambiental definida pelo IBAMA

Tabela 33 - Distribuição dos Produtos Comerciais registrados após a "Lei dos Agrotóxicos" (Lei 7802/89), segundo as Classe de Uso e a época de registro dos seus Ingredientes Ativos.

Tabela 34 - Distribuição dos Produtos Comerciais registrados após a "Lei dos Agrotóxicos" (Lei 7802/89), segundo a Classe Toxicológica e a época de registro dos seus Ingredientes Ativos.

Tabela 35 - Distribuição dos Produtos Comerciais registrados posteriormente à "Lei dos Agrotóxicos" (Lei 7802/89), derivados dos Ingredientes Ativos que já estavam registrados em 1990, segundo a Classe de Uso e a Classe Toxicológica definida pelo Ministério da Saúde.

Tabela 36 - Distribuição dos Produtos Comerciais registrados posteriormente à "Lei dos Agrotóxicos" (Lei 7802/89), derivados dos Ingredientes Ativos que já estavam registrados em 1990, segundo a Classe de Uso e a Classe de Potencial de Periculosidade Ambiental definida pelo IBAMA. .78

Tabela 37 - Distribuição dos Produtos Comerciais registrados posteriormente à "Lei dos Agrotóxicos" (Lei 7802/89), derivados dos novos" Ingredientes Ativos, segundo a Classe de Uso e a Classe Toxicológica definida pelo Ministério da Saúde.

Tabela 38 - Distribuição dos Produtos Comerciais registrados posteriormente à "Lei dos Agrotóxicos" (Lei 7802/89), derivados dos novos" Ingredientes Ativos, segundo a Classe de Uso e a Classe de Potencial de Periculosidade Ambiental definida pelo IBAMA.

Tabela 39 - Distribuição do número de Produtos Comerciais que estavam registrados em 1990 e 2000, segundo a cultura/produto de destinação, a eliminação, a entrada e o crescimento de registros identificados no período.

Tabela 40 - Distribuição dos Produtos Comerciais registrados posteriormente à "Lei dos Agrotóxicos" (Lei 7802/89), segundo a cultura/produto de destinação e a Classe de Uso.

Tabela 41 - Distribuição dos Produtos Comerciais registrados posteriormente à "Lei dos Agrotóxicos" (Lei 7802/89), segundo a cultura/produto de destinação e a Classe Toxicológica. 
Tabela 42 - Distribuição dos Produtos Comerciais registrados posteriormente à "Lei dos Agrotóxicos" (Lei 7802/89), segundo a cultura/produto de destinação e a Classe de Potencial de Periculosidade Ambiental.

Tabela 43 - Distribuição dos Produtos Comerciais que estavam registrados para o controle do "pulgão do algodoeiro" (Aphis gossypii) em 1990 e dos produtos que deixaram de ser registrados para essa finalidade após essa data e até 2000 , segundo a Classe Toxicológica.

Tabela 44 - Distribuição dos Produtos Comerciais que permaneceram registrados após a "Lei dos Agrotóxicos" (Lei 7802/89) para o controle do "pulgão do algodoeiro" (Aphis gossypii), dos novos* produtos e do total que estava registrado em 2000, segundo a Classe Toxicológica.

Tabela 45 - Distribuição dos Produtos Comerciais registrados após a "Lei dos Agrotóxicos" (Lei 7802/89), para o controle do "pulgão do algodoeiro" (Aphis gossypii), segundo a Classe Toxicológica e a época de registro do Ingrediente Ativo. 


\section{SIGLAS EMPREGADAS NO TEXTO}

AENDA

ANDEF

ANVISA

CNNPA

DISAD

EPA

FAO

FUNDACENTRO

IBAMA

OIT

OMS

SDA

SDSV

SEMA

SINDAG

SNDA

SNVS
Associação das Empreses Nacionais de Defensivos Agrícolas

Associação Nacional de Defesa Vegetal.

Agência Nacional de Vigilância Sanitária

Comissão Nacional de Normas e Padrões para Alimentos, do Ministério da Saúde.

Divisão Nacional de Vigilância Sanitária de Produtos Saneantes Domissanitários, do Ministério da Saúde.

Environmental Protection Agency (Agência de Proteção Ambiental dos EUA).

Food and Agriculture Organization of United Nations.

Fundação Jorge Duprat Figueiredo de Segurança e Medicina do Trabalho, Ministério do Trabalho.

Instituto Brasileiro do Meio Ambiente e dos Recursos Naturais Renováveis, Ministério do Interior, atualmente, Ministério do Meio Ambiente, dos Recursos Hídricos e da Amazônia Legal.

Organização Internacional do Trabalho.

Organização Mundial da Saúde.

Secretaria de Defesa Agropecuária (antiga SNDA), do Ministério da Agricultura.

Secretaria de Defesa Sanitária Vegetal, do Ministério da Agricultura e Abastecimento.

Secretaria Especial do Meio Ambiente, do Ministério do Interior.

Sindicato Nacional da Indústria de Produtos para Defesa Agropecuária

Secretaria Nacional de Defesa Agropecuária (hoje SDA), do Ministério da Agricultura.

Secretaria Nacional de Vigilância Sanitária, do Ministério da Saúde. 


\section{INTRODUÇÃo}

\subsection{A motivação, as limitações e a relevância do trabalho}

É comum alegar que os problemas provocados pelos agrotóxicos seriam decorrentes do uso inadequado desses produtos, pois a legislação e o sistema de registro seriam tão rígidos e evoluídos que garantiriam que os produtos colocados à disposição do usuário seriam seguros se fossem bem utilizados. Como foi discutido detalhadamente por este autor na sua dissertação de mestrado ${ }^{26}$ a inconsistência desses argumentos que responsabilizam apenas o uso e o usuário dos agrotóxicos pelos problemas, optou-se neste trabalho por realizar um estudo que permitisse conhecer melhor o papel da legislação e, em particular, das classificações toxicológica e de potencial de periculosidade ambiental realizadas para o registro desses produtos, como instrumentos de controle dos impactos indesejáveis desses insumos.

Avaliar impactos de políticas públicas não é tarefa simples, especialmente no caso das políticas que se colocam na interface entre a produção, ambiente e saúde pública, como é o caso de uma legislação que se propõe a controlar o uso de agrotóxicos. Nesse sentido, a proposição e principalmente a execução desta proposta foi um desafio, mas muito mais pela dificuldade na obtenção de informações essenciais do que por complexidade, o que foi determinante na definição e detalhamento do desenho proposto.

Uma das principais dificuldades foi a de identificar indicadores propícios e, principalmente, disponíveis. Numa proposição mais abrangente certamente um trabalho de avaliação de impactos deveria incluir a análise de indicadores como, por exemplo, a comparação de dados de contaminação ambiental em águas, solos, fauna e flora, ou de contaminação de alimentos, identificando a variação ocorrida entre o período anterior e o posterior à Lei. Mas a disponibilidade de dados e informações 
consistentes é tão limitada nessas áreas que, embora eventualmente possam permitir algumas inferências, não possibilitam uma análise comparativa confiável. O mesmo ocorre com informações sobre agravos crônicos provocados por exposição a agrotóxicos. Já com relação à ocorrência de intoxicações agudas, apesar da grande subnotificação presente, alguns dados originários de fontes de sistemas de registro mais consolidados foram empregados como indicadores possibilitando, com as devidas ressalvas, análise relevante.

Outra dificuldade está na limitada disponibilidade de informações oficiais sobre os registros e os produtos registrados. A começar pela própria aprovação do registro, que não é publicada no Diário Oficial da União. Publica-se a solicitação do registro, por ser obrigatório, mas não se dá publicidade à aprovação do registro, por que não foi prevista na legislação. Assim é dificil saber, por exemplo, quando exatamente um produto foi registrado.

Também os dados sobre as características dos agrotóxicos registrados são limitados. As informações disponíveis são as mínimas necessárias para o uso dos produtos e geralmente são as que estão disponíveis nos rótulos e bulas (marca, ingrediente ativo, usos autorizados, indicações de uso, recomendações e precauções, primeiros socorros, informações médicas, Classe Toxicológica, Classe de Potencial de Periculosidade Ambiental etc.). Mas não é dada publicidade aos dados que geraram essas informações como, por exemplo, os resultados dos testes agronômicos, toxicológicos e ambientais apresentados para o registro. Como conhecer os resultados dos testes de toxicidade crônica dos produtos registrados, como os de carcinogenicidade, por exemplo, se não forem publicados?

Outros dados de fundamental importância seriam os referentes às quantidades utilizadas de agrotóxicos: saber o que, quanto e onde está sendo utilizado. Essas informações permitiriam identificar áreas de risco, possibilitando definir e priorizar ações específicas de prevenção e controle dos impactos decorrentes do uso dos agrotóxicos $^{28}$. No entanto, esses dados atualmente também não estão disponíveis. 
A grande dificuldade de acesso a esses tipos de dados por pesquisadores restringe as possibilidades de realização de estudos para o aprimoramento do sistema e das exigências de registro e de estudos como, por exemplo, os que têm finalidade de comparar os impactos à saúde e ao ambiente provocados por diferentes produtos químicos ou outras técnicas de controle fitossanitário visando a proposição e adoção de práticas agrícolas menos danosas; estudos esses que são hoje de importância reconhecida para promover a redução de riscos nessas atividades ${ }^{\mathbf{4 2}}$.

Mas é preciso considerar que, de certa forma, essas dificuldades também fazem parte da avaliação das implicações da "Lei dos Agrotóxicos" e, se por um lado limitam a capacidade de análise, por outro, tornam ainda mais evidente a necessidade de aprofundar o conhecimento sobre as questões relacionadas ao registro de agrotóxicos, as classificações toxicológica e ambiental e suas implicações no controle desses produtos.

A importância de instrumentos legais para o controle de substâncias perigosas é indiscutível. No caso das substâncias químicas empregadas para o controle de pragas e doenças da agricultura, a chamada "Lei dos Agrotóxicos", promulgada em

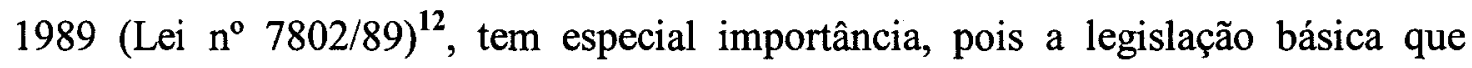
estava em vigor antes dela' era de 1934, época em que os produtos organossintéticos, hoje largamente empregados, sequer eram empregados como agrotóxicos.

Entre os vários assuntos que a "Lei dos Agrotóxicos" regulamentou, sem dúvida, o registro de agrotóxicos tem grande peso: é o elo inicial de toda a corrente. É no processo de registro que as substâncias são avaliadas em seus aspectos de eficiência agronômica e de impactos potenciais à saúde pública e ao ambiente. É ele que define se determinada substância ou produto comercial pode ser empregado e sob que condições. É a partir do registro que são definidos praticamente todos os demais aspectos relacionados ao controle e uso dos agrotóxicos.

O registro de agrotóxicos já era praticado antes", mas a "Lei dos Agrotóxicos" foi considerada um avanço do ponto de vista da preservação da saúde pública e do ambiente, principalmente por introduzir novos instrumentos de controle, 
explicitando, por exemplo, os aspectos toxicológicos e ambientais que podem impedir o registro ou, ainda, permitindo que a sociedade civil organizada possa propor o cancelamento ou a impugnação de registros.

Mas determinados aspectos da regulamentação da "Lei dos Agrotóxicos" também trouxeram algumas preocupações, como por exemplo os que se referem à classificação toxicológica dos produtos registrados. A mudança nos critérios de classificação fez com que produtos antes classificados nas classes consideradas de maior periculosidade à saúde passassem para classes de menor periculosidade. As implicações dessas mudanças na comunicação de riscos utilizada nos rótulos pode ter agravado os impactos de ocorrências de intoxicações agudas provocadas pelo uso dos agrotóxicos.

Assim algumas questões se colocam: Os instrumentos da Legislação que se mostravam como um avanço na evolução das exigências toxicológicas e ambientais para o registro têm se mostrado efetivos? A nova legislação está favorecendo de fato o registro de produtos de menor impacto à saúde e ao ambiente?

Passados mais de dez anos da promulgação da "Lei dos Agrotóxicos" uma análise mais profunda das conseqüências da sua aplicação é oportuna e poderá oferecer elementos importantes para melhor conhecer o papel da legislação como instrumento de controle dos impactos decorrentes do uso de agrotóxicos.

\subsection{Agrotóxicos: uso e impactos}

Com o objetivo de aumentar a produtividade, a partir da década de 1960 várias tecnologias foram associadas ao processo de modernização da agricultura, entre elas os agrotóxicos ${ }^{13}$. O uso generalizado e intensivo dessas substâncias tem gerado diversos problemas relacionados à saúde pública e ao desequilíbrio ambiental, incluindo: intoxicações de agricultores; contaminações de alimentos, de águas e de solos; resistência de espécies combatidas às substâncias empregadas e danos em espécies não visadas ${ }^{13,26}$. O desequilíbrio ecológico ocasionado acarreta problemas à 
própria agricultura, agravando o surgimento e proliferação de pragas e doenças e, conseqüentemente, aumentando a necessidade de usar agrotóxicos, conforme já alertava PASCHOAL $^{59}$ no final da década de 1970 , quando observou que, entre 1958 e 1976, quatrocentas novas espécies de pragas foram referidas no Brasil.

Embora de difícil avaliação, os custos sociais e ambientais decorrentes do uso de agrotóxicos são altos ${ }^{26}$. A Organização Mundial da Saúde (OMS) ${ }^{80}$ estima que, no mundo, mais de 500 milhões de pessoas se exponham aos agrotóxicos pelo trabalho agrícola e que ocorram 3 milhões de intoxicações severas, incluindo 1 milhão de casos de intoxicações agudas não intencionais com 20.000 mortes, anualmente, sendo $70 \%$ desses casos por exposição ocupacional. Estima ainda que os efeitos crônicos, que são mais dificeis de serem avaliados, incluam 25.000 casos de seqüelas neuro-comportamentais, 37.000 casos de câncer, principalmente em países em desenvolvimento, e 700.000 casos de dermatoses, por ano.

No Brasil estima-se que em torno de 15 milhões de pessoas que trabalham na agricultura estejam potencialmente expostas aos agrotóxicos, a quantidades bastante significativas, e que, entre elas, ocorram de 150.000 a 200.000 intoxicações agudas anualmente, com 3.000 a 4.000 óbitos ${ }^{26,27,28}$.

Dados e estimativas sobre outros impactos à saúde ou ao ambiente são dificeis de se obter, mas, segundo pesquisadores da EMBRAPA (CAMPANHOLA ${ }^{13}$ e col.), o balanço custo-benefício do uso de agrotóxicos no Brasil está deixando a desejar:

A evolução do consumo (de agrotóxicos) apresentou um aumento de 16,0 mil ton. em 1964 para 60,2 mil ton. em 1991, enquanto a área ocupada com lavouras agricolas expandiu-se de 28,4 para 50,0 milhões de ha no mesmo periodo. Isso significa um aumento de $276,2 \%$ no consumo de agrotóxicos para um aumento comparado de $76 \%$ em área. Como nesse periodo foram lançados novos produtos em que a quantidade de ingrediente ativo recomendada por hectare é menor, conclui-se que mesmo com produtos mais efetivos ocorreu aumento expressivo de uso. A despeito desse aumento no 
emprego desses produtos, as perdas atribuidas a pragas e doenças não sofreram reduções drásticas, enquanto os ganhos de produtividade foram relativamente restritos. Por outro lado, problemas de contaminação de alimentos, do ambiente e casos de intoxicação de agricultores aumentaram significativamente.

Em 2000 foram vendidas 140 mil toneladas de ingredientes ativos ${ }^{69}$, contrariando previsões econômicas de que o aprimoramento da legislação deveria levar a uma redução de consumo ${ }^{21}$. As vendas de agrotóxicos no Brasil não só continuaram crescentes como tiveram um aumento bastante expressivo: entre $1991 \mathrm{e}$ 2000 o aumento, em termos de valores de vendas, foi da ordem de $150 \%$, passando de aproximadamente US\$ 1 bilhão ${ }^{47}$ para US\$ 2,5 bilhões $^{69}$. A maior parte desse mercado é de algumas culturas que são grandes consumidoras de agrotóxicos, como a soja, o milho e o algodão que, em 2000 , consumiram quase $60 \%$ do total de vendas. Onze culturas responderam por quase $90 \%$ das vendas, são elas, além das três já citadas: cana-de-açúcar, café, citros, arroz, feijão, batata, trigo e tomate ${ }^{69}$, que também estão entre as principais lavouras em termos de área colhida no pais ${ }^{24}$. Os herbicidas são os agrotóxicos mais consumidos, detendo mais da metade do mercado, em termos de valores de vendas.

\subsection{A proposição da "Lei dos Agrotóxicos"}

A Lei $\mathrm{n}^{0} 7.802^{12}$, também chamada por "Lei dos Agrotóxicos", foi promulgada em 11 de julho de 1989. Anteriormente a ela a legislação que regulamentava o setor tinha como base um decreto promulgado 55 anos antes: 0 Decreto ${ }^{\circ} 24.114^{9}$, de 14 de abril de 1934.

O Decreto $\mathrm{n}^{\circ} 24.114 / 34^{9}$ instituiu o Regulamento de Defesa Sanitária Vegetal quando nem mesmo o poder inseticida do DDT era conhecido. Os produtos organossintéticos começaram a ser dirigidos para o uso agrícola mais de uma década depois. No entanto a legislação federal não acompanhou a evolução no setor até que, a partir da década de 1970, com o aumento da utilização dos agrotóxicos 
organossintéticos no país, procurou-se tentar suprir as deficiências legislativas usando principalmente do recurso da emissão portarias ${ }^{25,60}$.

Mas, com a crescente conscientização da opinião pública internacional quanto à necessidade de controlar os impactos decorrentes do uso dos agrotóxicos e, no Brasil, especialmente pela ação de alguns setores relacionados às áreas de agricultura, saúde e meio ambiente preocupados com o que vinha ocorrendo no país em termos do número de intoxicações de trabalhadores rurais e da contaminação de rios por agrotóxicos, deu-se início, no final dos anos 70, a um processo de discussão e de pressão pela reformulação dessa legislação ${ }^{25,43,60}$.

Nos anos 80 um grande fator de pressão, sem dúvida, foi a iniciativa do Rio Grande do Sul, seguida por outros Estados, com o propósito de regulamentar o controle dos agrotóxicos em âmbito estadual. As ações movidas pela então Associação Nacional de Defensivos Agrícolas - ANDEF, que representa os interesses das empresas multinacionais fabricantes de agrotóxicos, e pelo Sindicato da Indústria de Defensivos do Estado de São Paulo, argüindo a inconstitucionalidade dessas leis, vieram a evidenciar ainda mais a necessidade de uma legislação mais atualizada e intensificou os debates a respeito do assunto ${ }^{7,43,60}$.

Em outubro de 1984 foi encaminhado em regime de urgência ao Congresso o anteprojeto de uma nova lei federal, elaborado por representantes de diversos ministérios. Por ser considerado excessivamente centralizador e por severas restrições à forma como tratava as questões toxicológicas, um conjunto de entidades da sociedade civil apresentou um projeto de lei substitutivo baseado em proposta da Federação das Associações dos Engenheiros Agrônomos do Brasil - FAEAB ${ }^{\mathbf{6 0}}$.

A pressão fez com que o governo federal retirasse do Congresso o seu projeto e o substitutivo e propiciasse a elaboração de nova proposta, a partir de uma comissão heterogênea, com representantes dos diversos setores envolvidos, desde a indústria, até entidades ambientalistas ${ }^{43}$. Finalmente, 4 anos depois, em 1989, a "Lei dos Agrotóxicos" foi promulgada. 
Logo após a sua promulgação a Lei era vista sob diferentes pontos de vista. A indústria, que alegava que a legislação anterior já era das mais exigentes do mundo ${ }^{62}$, considerou que a nova legislação tornou "....extremamente rígidos os controles dos defensivos agrícolas...."22 e mesmo após a regulamentação da Lei ainda procurava alterá-la, movimentando principalmente alguns setores de produção agropecuária ${ }^{34}$. Já os segmentos que lutaram pela nova legislação a consideraram um grande $\operatorname{avanço~}^{29,34,41}$.

\subsection{Os avanços da "Lei dos Agrotóxicos"}

Considerando-se a importância e a necessidade de atualização da legislação referente aos agrotóxicos, o advento da Lei $n^{\circ} 7802 / 89$ por si já significou um grande avanço. Alguns itens do projeto substitutivo que eram considerados importantes não permaneceram na Lei aprovada, como, por exemplo, a não concessão de registro a produtos proibidos nos países de origem dos fabricantes ${ }^{\mathbf{3 4}, \mathbf{6 0}}$. Mas vários outros aspectos são de reconhecida importância.

O primeiro ponto considerado positivo por LAZZARINI ${ }^{41}$, um dos grandes batalhadores pela legislação, foi o uso do termo "agrotóxico", por deixar claro ao agricultor e à população que o produto é tóxico. Ele também considerou importante a obrigatoriedade da propaganda de agrotóxicos conter uma advertência explicita sobre os riscos do produto ao homem, animais e meio ambiente.

Outro ponto considerado fundamental e que contava com grande resistência por parte da Indústria foi a delegação de competência aos Estados e Municípios para legislar sobre o uso dos agrotóxicos ${ }^{25,34,41}$. A obrigatoriedade do Receituário Agronômico na venda e uso de agrotóxicos, prescrito por profissional habilitado, também era considerado ponto relevante da Lei, principalmente por disciplinar as vendas desses produtos ${ }^{25,41}$.

A definição de responsabilidades administrativas, civis e penais por danos causados à saúde e ao meio ambiente de todos os envolvidos, desde o fabricante ao 
usuário contou com o apoio da Indústria ${ }^{32}$ e também foi considerado importante devido a definição das penalidades e multas, cujos valores encontravam-se defasados $^{25}$.

Outros pontos são ainda de fundamental importância e, sem dúvida, podem ser apontados como de grande relevância no que se refere ao avanço da Lei nas questões ambientais e, principalmente, toxicológicas:

a) estabelece a necessidade imediata de providências das autoridades competentes quando houver alertas de organizações internacionais responsáveis pela saúde, alimentação ou meio ambiente;

b) só permite o registro de novo agrotóxico se for comprovadamente igual ou de menor toxicidade aos já registrados para o mesmo fim;

c) proíbe o registro de agrotóxicos para os quais o país não disponha de métodos de desativação, não haja antídoto ou tratamento eficaz, sejam carcinogênicos, teratogênicos ou mutagênicos, provoquem distúrbios hormonais ou danos ao aparelho reprodutor e que se mostrem ser mais perigosos ao homem do que o revelado por testes laboratoriais com animais ou, ainda, que sejam danosos ao ambiente.

d) legitima a solicitação de cancelamento ou impugnação do registro de agrotóxicos, por prejuízos à saúde e ao ambiente, aos partidos políticos, entidades de classe e entidades civis.

\subsection{A regulamentação da "Lei dos Agrotóxicos"}

\subsubsection{A regulamentação básica}

A regulamentação da Lei $n^{\circ} 7.802 / 89$ está baseada no Decreto $n^{\circ} 98.816^{\mathbf{1 0}}$, de 11 de janeiro de 1990. De modo geral, o decreto regulamentador cumpriu o seu 
papel, mas o processo de regulamentação não foi tão democrático quanto o da elaboração da Lei, ou seja, não foi amplamente discutido e negociado como a Lei o fora e em alguns aspectos descaracterizou o propósito da mesma, como mostra o comentário deste autor, em sua dissertação ${ }^{26}$, a respeito do artigo que trata da proibição de registro de agrotóxicos com características danosas:

....Por exemplo: no caso da proibição do registro de agrotóxicos para os quais não haja antídoto ou tratamento eficaz, a regulamentação abriu uma exceção para produtos "usados em concentrações comprovadamente não letais para os homens e animais". Se normalmente o que leva à necessidade de um tratamento é uma exposição excessiva, portanto fora dos padrões de uso recomendados, como interpretar a regulamentação? Seriam excluidos da análise qualquer possibilidade de eventos acidentais? Um produto que provoque alta mortalidade por uso indiscriminado não poderia ser proibido? O que significa "usados": a recomendação técnica ou a quantidade efetivamente empregada na aplicação? Deveriam ser permitidos usos em concentrações letais para o homem, se houvessem antidotos?

Sob outros aspectos a regulamentação é limitada ou pouco esclarecedora. Por exemplo:

- o decreto exige a publicação da solicitação do registro no Diário Oficial da União, mas a divulgação do resultado do processo de registro e dos dados que foram aprovados não é de publicação obrigatória e, de fato, não são publicados pelo órgão registrante (Ministério da Agricultura);

- na regulamentação do artigo que determina que somente poderão ser registrados produtos de toxicidade igual ou menor aos já registrados não há clareza quanto aos critérios para a comparação, pois os critérios estabelecidos foram por demais genéricos, como pode ser observado no texto do decreto: "Para avaliação comparada da toxicidade, na área da saúde e do meio ambiente, devem ser observados os seguintes parâmetros: a)toxicidade da 
formulação, b)presença de problemas toxicológicos especiais, c)persistência no ambiente, d)bioacumulação, e)formulação e f)método de aplicação". O Ministério da Saúde procurou definir alguns desses aspectos na Portaria SNVS $\mathrm{n}^{\mathrm{o}} 3 / 92^{54}$, que regulamentou as suas diretrizes para fins de registros dos agrotóxicos, mas não aborda todos os parâmetros acima mencionados.

O Decreto $\mathrm{n}^{\circ}$ 98.816/90 passou por uma reformulação de grande impacto através das alterações propostas pelo Decreto $\mathrm{n}^{\circ}$ 991 ${ }^{11}$, de 24 de novembro de 1993. O primeiro estabelecia a validade de 5 anos para o registro, podendo ser renovado através dos mesmos procedimentos do registro. Isto não foi nenhuma novidade, afinal a validade de 5 anos era adotada desde 1934. ${ }^{9}$. Mas o Decreto $\mathrm{n}^{\circ}$ 991/93, sem qualquer justificativa e aproveitando a omissão da Lei $\mathrm{n}^{0} 7.802 / 89$ com relação à renovação de registro, modificou todos os artigos que tratavam do tema, eliminando a necessidade de renovação, mantendo apenas a possibilidade de reavaliação do registro a qualquer tempo caso os agrotóxicos apresentem redução da sua eficiência agronômica ou riscos à saúde ou ao meio ambiente. Na prática isto pode implicar em, pelo menos, dois aspectos importantes do ponto de vista do controle dos agrotóxicos:

- considerando-se que ao haver a renovação de registro poderia ser aplicado o artigo da Lei que só permite o registro de produtos de menor toxicidade para a mesma finalidade, perde-se a oportunidade de eliminar produtos antigos, de maior toxicidade.

- um produto registrado só perderá seu registro se houver uma proposição explicita de reavaliação ou por iniciativa da própria empresa registrante, caso contrário, mesmo que o produto deixe de ser comercializado, seu registro poderá ser mantido indefinidamente, podendo até, por questões comerciais, sua titularidade ser repassada para outra empresa que possa vir a se interessar em, por exemplo, recolocar um produto antigo no mercado.

FUTINO e SILVEIRA ${ }^{25}$ fazem a seguinte colocação: 
A nova legislação, semelhante aos (sic) dos paises mais desenvolvidos, apresenta agora questões que afetam diretamente as empresas no seu processo concorrencial, tais como: a) do ponto de vista da produção de defensivos, no tocante à exigência de dados toxicológicos e ambientais para o registro de produtos. Esse fato poderá inviabilizar os produtos muito difundidos, com patentes vencidas, pois os altos custos de atualizações toxicológicas e ambientais poderão ser incompatíveis às magnitudes dos respectivos mercados, em função dos seus comportamentos como "commodities" (produtos genéricos). Esta questão poderá ser problemática às empresas de pequeno e médio porte, especialmente as nacionais. Acrescenta-se que a permanência de um mercado forte de produtos genéricos, porém eficientes, permite o uso de agroquímicos aos agricultores menos capitalizados.

Considerando-se essas colocações, poderia se dizer que, de certa forma, o Decreto 991/93 pode ter amenizado essa situação para algumas empresas registrantes, e talvez ajudado economicamente alguns agricultores menos capitalizados, mas do ponto de vista da segurança no trabalho, da saúde pública e do ambiente, o interesse maior deve ser pela restrição aos produtos de maior periculosidade. Portanto, a ausência da renovação de registro pode ser considerada um retrocesso, na medida em que não possibilita que produtos já registrados venham necessariamente a ser periodicamente reavaliados à luz de novos conhecimentos e testes mais modernos e precisos.

\subsubsection{A regulamentação relacionada à área da agricultura}

Pelo Decreto $\mathrm{n}^{\circ}$ 98.816/90 compete ao Ministério da Agricultura conceder o registro de agrotóxicos com finalidade fitossanitária, atendidas as diretrizes e exigências dos Ministérios da Saúde e do Meio Ambiente. A Portaria SNDA $n^{\circ}$ $45 / 90^{45}$ define a regulamentação básica da área de agricultura referente aos procedimentos e informações necessárias para o registro. Nela são definidos os parâmetros para os testes de eficiência e praticabilidade agronômica exigidos. 
Mas a regulamentação que levantou mais polêmica, até entre os próprios órgãos registrantes, foi a Portaria SDA $\mathrm{n}^{0} 67 / 95^{46}$, que regulamentou a mistura em tanque de agrotóxicos, ou seja, “.... a prática de associar, imediatamente antes da aplicação, agrotóxicos ou afins necessários ao controle de alvos biológicos que ocorrem simultaneamente, para os quais não se obtenha eficácia desejada com um único produto."

As considerações iniciais dessa portaria ${ }^{46}$ dizem que "a prática de mistura de agrotóxicos ou afins em tanque constitui técnica agronômica utilizada mundialmente com êxito". Já, segundo artigo na Revista Proteção ${ }^{15}$, essa prática é “altamente perigosa e proibida em qualquer país desenvolvido....". O que acontece é que a portaria busca regulamentar o que na realidade é uma prática comum, mas a polêmica se dá pelo fato de que as avaliações para fins de registro são feitas para cada produto isoladamente e, de modo geral, não se conhecem os possíveis efeitos à saúde e ao ambiente da mistura de produtos.

\subsubsection{A regulamentação relacionada à área ambiental}

A regulamentação ambiental parece estar sendo continuamente aprimorada. As exigências de informações relacionadas aos efeitos sobre o ambiente estão previstas pelo menos desde 1980, quando ainda eram solicitadas pela área da Saúde através da Portaria DISAD $n^{\circ} 4 / 80^{53}$. Os dados exigidos eram: toxicidade para peixes, organismos aquáticos inferiores, aves, abelhas e fauna silvestre; acumulação na cadeia alimentar, deslocamento no ambiente, persistência e degradação no ambiente; toxicidade do produto degradado. Em 1985 a responsabilidade pela solicitação e análise dos dados sobre os efeitos no meio ambiente foi passada à Secretaria Especial do Meio Ambiente - SEMA, do Ministério do Interior, através da Portaria SDSV n ${ }^{\circ} 06 / 85^{44}$.

Após a "Lei dos Agrotóxicos" foi a Portaria Normativa IBAMA n $349 / 90^{\mathbf{3 5}}$, que definiu os dados ambientais necessários ao registro. As informações exigidas sobre os produtos já eram bem mais abrangentes e consistiam basicamente em: propriedades fisico-químicas; toxicidade para microorganismos, microcrustáceos, 
peixes, algas e organismos do solo; processos de degradação e transporte; toxicidade para animais superiores (mamíferos) e efeitos neurotóxicos; potencial mutagênico, embrio-fetotóxico e carcinogênico.

Essa portaria foi revogada pela Portaria Normativa IBAMA n ${ }^{\circ} 139 / 94^{36}$ que estabeleceu os procedimentos e testes ecotoxicológicos necessários para a avaliação do Potencial de Periculosidade Ambiental dos agrotóxicos. Por sua vez, essa portaria foi substituída pela Portaria IBAMA $\mathrm{n}^{\mathrm{o}} 84 / 96^{37}$, que estabelece novamente os procedimentos para registro e institui o Sistema Permanente da Avaliação e Controle dos Agrotóxicos. Esse Sistema inclui a classificação do Potencial de Periculosidade Ambiental (Tabela 1), o estudo de conformidade (aferição de informações apresentadas para fins de registro), a avaliação do risco ambiental, a divulgação de informações, o monitoramento ambiental e a fiscalização.

\begin{tabular}{cl}
\hline \multicolumn{2}{c}{ Tabela 1 - Classes de Potencial de Periculosidade Ambiental } \\
\hline Classe & Graduação \\
\hline I & Produto Altamente Perigoso \\
II & Produto Muito Perigoso \\
III & Produto Perigoso \\
IV & Produto Pouco Perigoso \\
\hline
\end{tabular}

Fontes: Portaria IBAMA n ${ }^{\circ} 84 / 96^{37}$

Sem dúvida, ao instituir um sistema para lidar com as questões dos agrotóxicos e estabelecer a avaliação de risco, a área ambiental está dando um grande passo, que vai além do aprimoramento das exigências, e se coloca na perspectiva de tratar a questão dos agrotóxicos como o fazem os países desenvolvidos.

\subsubsection{A regulamentação relacionada à área da saúde}

Entre as principais competências da área da saúde está a de avaliar e classificar toxicologicamente os agrotóxicos. A regulamentação da classificação 
toxicológica dos agrotóxicos é um exemplo claro das dificuldades relacionadas ao gerenciamento de riscos relacionados à saúde. A Portaria SNVS $n^{\circ} 3 / 92^{54}$ que ratificou os termos das "Diretrizes e orientações referentes à autorização de registros, renovação de registro e extensão de uso de produtos agrotóxicos e afins $n^{\circ} 1$, de 09/12/91", modificou bastante alguns critérios anteriores que eram definidos pela Portaria DISAD n $\mathrm{n}^{\mathbf{0}} 4 / 80^{53}$, acarretando que produtos anteriormente enquadrados nas classes de maior periculosidade à saúde viessem a ser classificados nas de menor periculosidade, podendo implicar em agravamento dos impactos indesejáveis, como discutiremos em maior detalhe mais adiante.

COPPLESTONE ${ }^{16}$ comenta que a idéia de se fazer uma classificação de periculosidade para os agrotóxicos surgiu a partir das preocupações suscitadas durante os anos 60 quanto aos efeitos secundários dessas substâncias. Isso provocou um grande desenvolvimento de pesquisas toxicológicas e ambientais, gerando tantos dados que a interpretação dessas informações tornou-se difícil, implicando em regulamentações bastante distintas em diferentes países.

Ainda segundo COPPLESTONE ${ }^{16}$ essa diversidade na classificação de agrotóxicos não era surpreendente porque geralmente ela se dava com base no valor $\mathrm{DL}_{50}{ }^{*}$. Como esses valores são contínuos, há um grande número de opções para a escolha das faixas das classes. Além disso, como a $\mathrm{DL}_{50}$ é um valor estimado, os limites e intervalos de confiança para uma dada substância podem alargar a faixa de uma classe, deixando sua classificação inconsistente sob diferentes esquemas.

No início dos anos 70 a Organização Mundial da Saúde - OMS, sentindo a necessidade do estabelecimento de critérios para a interpretação dos dados e proposição de medidas de controle, resolveu propor uma classificação de periculosidade á saúde para agrotóxicos que pudesse servir de guia, principalmente para os países em desenvolvimento, o que foi feito em 1975 com a adoção do

\footnotetext{
$\mathrm{O}$ valor $\mathrm{DL}_{50}$ é uma estimativa estatística do número de miligramas de tóxico por quilogramas de peso vivo requerido para matar $50 \%$ de uma grande população de animais ${ }^{81}$.
} 
documento The WHO Recommended Classification of Pesticides by Hazard pela $28^{\mathrm{a}}$ Assembléia Mundial de Saúde ${ }^{\mathbf{8 1}}$.

O primeiro texto da Classificação da OMS trazia um anexo no qual exemplos de enquadramentos de alguns ingredientes ativos e de suas formulações eram apresentados. Depois, em 1978, atendendo a sugestões de Estados Membros e de autoridades responsáveis por registros de pesticidas sobre a necessidade de informação adicional, um guia contendo informações específicas dos pesticidas, para fins de classificação, foi produzido e passou a ser apresentado como anexo do documento original. ${ }^{81}$

O guia tem sido atualizado a cada dois anos e apresenta uma tabela para cada classe, contendo uma lista em ordem alfabética dos produtos técnicos cuja continuidade da comercialização seja de conhecimento ou que tenham sido comercializados nos 5 ou 6 anos anteriores e ainda possam estar disponíveis em algumas partes do mundo. As revisões periódicas do guia permitem mudanças na classificação de produtos, baseadas em novas informações, e a inclusão de substâncias que ainda não constavam da relação ${ }^{16}$. O número de pesticidas classificados vem crescendo: em 1988-89 constavam 905 ingredientes ativos ${ }^{16}$, na edição de 1998-99 eram 976 substâncias $^{82}$.

A classificação da OMS propõe diferentes classes de periculosidade baseadas principalmente na toxicidade aguda oral e dermal do ingrediente ativo (grau técnico) e das suas formulações, pois suas determinações são realizadas por procedimentos padronizados pela toxicologia ${ }^{16,81}$ : A periculosidade referida na Recomendação é o risco agudo à saúde, ou seja, aquele resultante de uma exposição simples ou múltipla em um relativo curto periodo de tempo, o que pode ocorrer de forma acidental ou durante a manipulação do produto de acordo com as instruções do fabricante ou normas baixadas pelas organizações internacionais competentes de armazenamento e transporte ${ }^{\mathbf{8 1}}$.

COPPLESTONE ${ }^{16}$ comenta: O conceito de periculosidade é introduzido pela classificação de acordo com o estado fisico (sólido ou líquido) de cada produto técnico ou formulação. Os limites das classes são baseados em escala logarítma de 
valores da $D L_{50}$. Valores de $D L_{50}$ (oral) para ratos são usados, mas se o valor da $D L_{50}$ dermal para ratos colocar um dado produto em uma classe de maior periculosidade, esse valor é o utilizado como referência para a classificação. $\mathrm{O}$ autor comenta, ainda, que é a formulação que deve ser classificada e que, se não houver dados de testes específicos, a $\mathrm{DL}_{50}$ da formulação pode ser estimada a partir dos dados de seus produtos técnicos constituintes.

A Tabela 2 mostra as classes de periculosidade definidas pela OMS.

Tabela 2 - Classificação de agrotóxicos segundo a periculosidade*, recomendada pela Organização Mundial da Saúde - OMS.

\begin{tabular}{|c|c|c|c|c|c|c|}
\hline $\begin{array}{c}\mathbf{D L}_{50} \\
(\mathbf{m g} / \\
\mathbf{k g})\end{array}$ & $\begin{array}{l}\text { Estado } \\
\text { físico }\end{array}$ & $\begin{array}{c}\text { Classe Ia } \\
\text { Extremamente } \\
\text { Perigoso }\end{array}$ & $\begin{array}{l}\text { Classe Ib } \\
\text { Altamente } \\
\text { Perigoso }\end{array}$ & $\begin{array}{c}\text { Classe II } \\
\text { Moderadamente } \\
\text { Perigoso }\end{array}$ & $\begin{array}{c}\text { Classe III } \\
\text { Levemente } \\
\text { Perigoso }\end{array}$ & $\begin{array}{l}\text { Classe III+ } \\
\text { Improvável de } \\
\text { apresentar } \\
\text { perigo sob uso } \\
\text { normal } \\
\end{array}$ \\
\hline \multirow[t]{2}{*}{ oral } & Sólido & $\leq 5$ & $5-50$ & $50-1500$ & $>500$ & $>2000$ \\
\hline & Líquido & $\leq 20$ & $20-1200$ & $200-12000$ & $>2000$ & $>3000$ \\
\hline \multirow[t]{2}{*}{ dermal } & Sólido & $\leq 10$ & $10-\mid 100$ & $100-1000$ & $>1000$ & - \\
\hline & Líquido & $\leq 40$ & $40-1400$ & $400-14000$ & $>4000$ & - \\
\hline
\end{tabular}

* periculosidade: definida pela OMS como "risco agudo à saúde".

** se refere ao estado físico do produto ou formulação classificada.

*** Esta subdivisão corresponde à Tabela 5 no Guia para classificação dos agrotóxicos segundo a periculosidade ${ }^{82}$.

Fonte: modificado de Copplestone, $1988^{16} ; \mathrm{WHO}^{82}$

No Brasil a classificação de agrotóxicos de acordo com a toxicidade existe, pelo menos, desde $1977^{3}$, mas foi a Portaria DISAD $n^{\circ} 4^{53}$, em 1980, que definiu a classificação toxicológica vigente até a regulamentação específica da "Lei dos Agrotóxicos", feita pelo Ministério da Saúde através da Portaria SNVS $\mathrm{n}^{\circ} 3^{54}$, em 1992. Ambas classificam os agrotóxicos em quatro Classes Toxicológicas definidas principalmente pela $\mathrm{DL}_{50}$ dos produtos classificados, embora outros indicadores relacionados a danos na córnea, lesões na pele e Concentração Letal Inalatória $\left(\mathrm{CL}_{50}\right)$ para ratos (Tabela 5) também possam determinar a classificação de um produto: “ $A$ classificação de uma substância ou formulação em uma das Classes Toxicológicas previstas não depende de todos os dados toxicológicos estarem na mesma classe. $O$ dado mais agravante será utilizado para classificar o produto" ${ }^{\mathbf{5 4}}$. 
A Tabela 3 mostra os critérios de classificação toxicológica relacionados à $\mathrm{DL}_{50}$ vigentes antes da "Lei dos Agrotóxicos".

Tabela 3 - Parâmetros referentes à $\mathrm{DL}_{50}$ estabelecidos para a classificação toxicológica de agrotóxicos pela Portaria DISAD n ${ }^{\circ}$ 4, de 30 de abril de 1980.

\begin{tabular}{c|c|c|c|c|c}
\hline $\begin{array}{c}\mathbf{D L}_{\mathbf{5 0}} \\
(\mathbf{m g} / \mathbf{k g})\end{array}$ & $\begin{array}{c}\text { Estado } \\
\text { físico }\end{array}$ & $\begin{array}{c}\text { Classe I } \\
\text { Altamente } \\
\text { tóxico }\end{array}$ & $\begin{array}{c}\text { Classe II } \\
\text { Medianamente } \\
\text { tóxico }\end{array}$ & $\begin{array}{c}\text { Classe III } \\
\text { Pouco } \\
\text { tóxico }\end{array}$ & $\begin{array}{c}\text { Classe IV } \\
\text { Praticamente } \\
\text { não tóxico }\end{array}$ \\
\hline oral & Sólido & $\leq 100$ & $100-\mid 500$ & $500-\mid 2000$ & $>2000$ \\
& Líquido & $\leq 200$ & $200-\mid 2000$ & $2000-\mid 6000$ & $>6000$ \\
\hline dermal & Sólido & $\leq 200$ & $200-\mid 1000$ & $1000-\mid 4000$ & $>4000$ \\
& Líquido & $\leq 400$ & $400-\mid 4000$ & $4000-\mid 12000$ & $>12000$ \\
\hline
\end{tabular}

Fonte: Portaria DISAD n ${ }^{\circ} 4 / 80^{53}$

A Tabela 4 apresenta os parâmetros de classificação relacionados à $\mathrm{DL}_{50}$ após a regulamentação da "Lei dos Agrotóxicos".

Tabela 4 - Parâmetros referentes à $\mathrm{DL}_{50}$ estabelecidos para a classificação toxicológica de agrotóxicos pela Portaria SNVS $n^{\circ} 3$, de 16 de janeiro de 1992, regulamentando a "Lei dos Agrotóxicos" (Lei 7802/89).

\begin{tabular}{c|c|c|c|c|c}
\hline $\begin{array}{c}\mathbf{D L}_{\mathbf{5 0}} \\
(\mathbf{m g} / \mathbf{k g})\end{array}$ & $\begin{array}{c}\text { Estado } \\
\text { físico }\end{array}$ & $\begin{array}{c}\text { Classe I } \\
\text { Extremamente } \\
\text { tóxico }\end{array}$ & $\begin{array}{c}\text { Classe II } \\
\text { Altamente } \\
\text { tóxico }\end{array}$ & $\begin{array}{c}\text { Classe III } \\
\text { Medianamente } \\
\text { tóxico }\end{array}$ & $\begin{array}{c}\text { Classe IV } \\
\text { Pouco } \\
\text { tóxico }\end{array}$ \\
\hline \multirow{2}{*}{ oral } & Sólido & $\leq 5$ & $5-\mid 50$ & $50-\mid 500$ & $>500$ \\
& Líquido & $\leq 20$ & $20-\mid 200$ & $200-\mid 2000$ & $>2000$ \\
\hline \multirow{2}{*}{ dermal } & Sólido & $\leq 10$ & $10-\mid 100$ & $100-\mid 1000$ & $>1000$ \\
\cline { 2 - 7 } & Líquido & $\leq 40$ & $40-\mid 400$ & $400-\mid 4000$ & $>4000$ \\
\hline
\end{tabular}

Fonte: Portaria SNVS n ${ }^{0} 3 / 92^{54}$ 
Na Tabela 5 são apresentados os demais parâmetros estabelecidos para a classificação toxicológica de formulações de agrotóxicos.

Tabela 5 - Critérios referentes à $\mathrm{CL}_{50}{ }^{*}$, lesões oculares e lesões dérmicas estabelecidos para a classificação toxicológica de agrotóxicos pela Portaria SNVS $n^{\circ} 3$, de 16 de janeiro de 1992, regulamentando a "Lei dos Agrotóxicos" (Lei 7802/89).

\begin{tabular}{|c|c|c|c|}
\hline $\begin{array}{c}\text { Classe } \\
\text { Toxicológica }\end{array}$ & $\begin{array}{c}\text { CL50 } \\
\text { inalatória } \\
\mathbf{m g} / \mathbf{l} / \mathbf{h} *\end{array}$ & Lesões Oculares & Lesões Dérmicas \\
\hline $\begin{array}{c}\text { Classe I } \\
\text { Extremamente } \\
\text { Tóxico }\end{array}$ & $\leq 0,2$ & $\begin{array}{l}\text { Formulações que provocam } \\
\text { opacidade na córnea reversível ou } \\
\text { não dentro de } 7 \text { dias ou irritação } \\
\text { persistente nas mucosas oculares } \\
\text { dos animais testados. }\end{array}$ & $\begin{array}{l}\text { Formulações que provocam } \\
\text { ulceração ou corrosão na pele } \\
\text { dos animais testados. }\end{array}$ \\
\hline $\begin{array}{l}\text { Classe II } \\
\text { Altamente } \\
\text { Tóxico }\end{array}$ & $>0,2 \mathrm{a} \leq 2$ & $\begin{array}{l}\text { Formulaçōes que não provocam de } \\
\text { modo algum opacidade na córnea, } \\
\text { bem como aquelas que provocam } \\
\text { irritação reversivel dentro de } 7 \text { dias } \\
\text { nas mucosas oculares dos animais } \\
\text { testados. }\end{array}$ & $\begin{array}{l}\text { Formulações que provocam } \\
\text { irritação severa, ou seja, } \\
\text { obtenham um escore igual ou } \\
\text { superior a } 5 \text {, segundo o método } \\
\text { de Draize e Cols, na pele dos } \\
\text { animais testados. }\end{array}$ \\
\hline $\begin{array}{c}\text { Classe III } \\
\text { Medianamente } \\
\text { Tóxico }\end{array}$ & $>2 a \leq 20$ & $\begin{array}{l}\text { Formulações que não provocam, de } \\
\text { modo algum, opacidade na córnea } \\
\text { e aquelas que provocam irritação } \\
\text { reversivel dentro de } 72 \text { horas nas } \\
\text { mucosas oculares dos animais } \\
\text { testados. }\end{array}$ & $\begin{array}{l}\text { Formulações que provocam } \\
\text { irritação moderada ou um escore } \\
\text { igual ou superior a } 3 \text { e até } 5 \text {, } \\
\text { segundo o método de Draize e } \\
\text { Cols, na pele dos animais } \\
\text { testados. }\end{array}$ \\
\hline $\begin{array}{l}\text { Classe IV } \\
\text { Pouco } \\
\text { Tóxico }\end{array}$ & $>20$ & $\begin{array}{l}\text { Formulações que não provocam, de } \\
\text { modo algum, opacidade na córnea, } \\
\text { e aquelas que provocam irritação } \\
\text { leve reversivel dentro de } 24 \text { horas, } \\
\text { nas mucosas oculares dos animais } \\
\text { testados. }\end{array}$ & $\begin{array}{l}\text { Formulações que provocam } \\
\text { irritação leve ou um escore } \\
\text { inferior a 3, segundo o método de } \\
\text { Draize e Cols, na pele dos } \\
\text { animais testados. }\end{array}$ \\
\hline
\end{tabular}

Comparando-se a Tabela 4 com a Tabela 2, tudo indica que a regulamentação da "Lei dos Agrotóxicos" reajustou as faixas dos valores da $\mathrm{DL}_{50}$, que definem as Classes Toxicológicas, para que ficassem idênticas à classificação da OMS. No entanto, a classificação toxicológica anterior (Tabela 3) apresentava uma maior amplitude para as faixas das classes I e II, de maior periculosidade. Por exemplo, no caso das formulações líquidas, ela praticamente ignorava a divisão da Classe I em Classe Ia e Ib proposta pela OMS, juntando-as em uma classe única, (Classe I - altamente tóxico). Na prática, ao adotar as faixas da OMS, produtos já registrados que eram enquadrados em classes de maior periculosidade ou que 
poderiam vir a receber classificação nessas classes no processo de registro passaram a ser classificados nas classes de menor periculosidade. Essas modificações podem ter significado um agravamento nos impactos provocados pelo uso dos agrotóxicos, provocando, por exemplo, um aumento nas ocorrências de intoxicações ${ }^{15,61}$.

Com relação aos demais parâmetros que podem definir a classificação toxicológica (Tabela 5), porém, ao contrário do ocorrido com a $\mathrm{DL}_{50}$, nos aspectos em que houve modificações, estas foram mais restritivas. Para a $\mathrm{CL}_{50}$ inalatória e as lesões dérmicas, os critérios que definem as quatro classes foram mantidos. Já no caso das lesões oculares, os parâmetros que definiam o enquadramento nas Classe III e II passaram, respectivamente, a determinar as Classes II e I, de maior periculosidade. Já os parâmetros que anteriormente implicavam no enquadramento do produto na Classe I (formulações que provocam corrosão, ulceração ou opacidade na córnea, irreversível dentro de sete dias após a aplicação nas conjuntivas dos animais testados) passaram a determinar a necessidade de realização de estudo especial pelo Ministério da Saúde para concessão ou não da classificação toxicológica $^{54}$. Da mesma forma, efeitos carcinogênicos, mutagênicos, teratogênicos ou sobre o processo reprodutivo, que pela regulamentação anterior implicavam enquadramento na Classe I, de maior periculosidade, atualmente não permitem a classificação toxicológica nem o registro do produto $^{10,54}$.

O propósito básico de classificar os agrotóxicos é distinguir entre os de maior e os de menor periculosidade ${ }^{81}$. Isto se aplica para os aspectos toxicológicos e ambientais. Essas diferenças podem, por exemplo, influenciar na distribuição dos agrotóxicos, fazendo com que os produtos de maior periculosidade sofram restrições de uso e só possam ser utilizados sob determinadas circunstâncias ou por aplicadores especialmente capacitados ${ }^{16,26,55}$. De modo geral a classificação tem servido para harmonizar as informações nos rótulos sobre os perigos que aquele produto pode implicar ${ }^{81}$.

No caso do Brasil a classificação toxicológica tem servido basicamente para definir a comunicação de riscos na rotulagem. Pelo menos desde 1979, quando foi publicada a Portaria $n^{\circ} 220^{49}$, conjuntamente pelos Ministérios da Saúde e da 
Agricultura, a classificação serve para definir dizeres e símbolos que devem constar do rótulo para fácil identificação do grau de periculosidade e descrição das precauções necessárias para o manuseio do produto.

A Classe Toxicológica é simbolizada por faixas coloridas que devem compor o rótulo e que são de fácil identificação: vermelho vivo para os produtos de Classe I (os mais tóxicos), amarelo intenso para os de Classe II, azul intenso para os de Classe III e verde intenso para os de Classe IV (os menos tóxicos). Esta simbologia foi mantida apesar da mudança nos critérios de classificação, o que pode estar confundindo os usuários. Além disso, a relação entre a cor e a denominação das Classes Toxicológicas também foi modificada: as denominações anteriores passaram a ser utilizadas para classes inferiores, conforme mostra a Tabela 6, o que pode aumentar ainda mais o desentendimento dos usuários.

\begin{tabular}{cccc}
\hline \multicolumn{2}{l}{ Tabela 6 } & Denominação das Classes Toxicológicas. & \\
\hline Classe & $\begin{array}{c}\text { Cor da } \\
\text { faixa }\end{array}$ & Portaria DISAD & Portaria SNVS \\
& $\mathbf{n}^{\circ} \mathbf{4 / 8 0}$ & $\mathbf{n}^{\circ} \mathbf{3 / 9 2}$ \\
\hline I & & Altamente tóxico & Extremamente tóxico \\
II & & Medianamente tóxico & Altamente tóxico \\
III & & Pouco tóxico & Medianamente tóxico \\
IV & & Praticamente não tóxico & Pouco tóxico \\
\hline
\end{tabular}

Fontes: Portaria DISAD n ${ }^{\circ} 4 / 80^{53}$ e Portaria SNVS n $3 / 92^{54}$

O impacto das mudanças dos critérios na reclassificação dos agrotóxicos pode ser melhor visualizado na Figura 1 e Figura 2 apresentadas a seguir. 
Figura 1 - Comparação entre as faixas de classificação toxicológica das Portarias DISAD $n^{0} 4 / 80\left(^{*}\right)$ e SNVS $n^{0} 3 / 92(* *)$, para formulações líquidas.

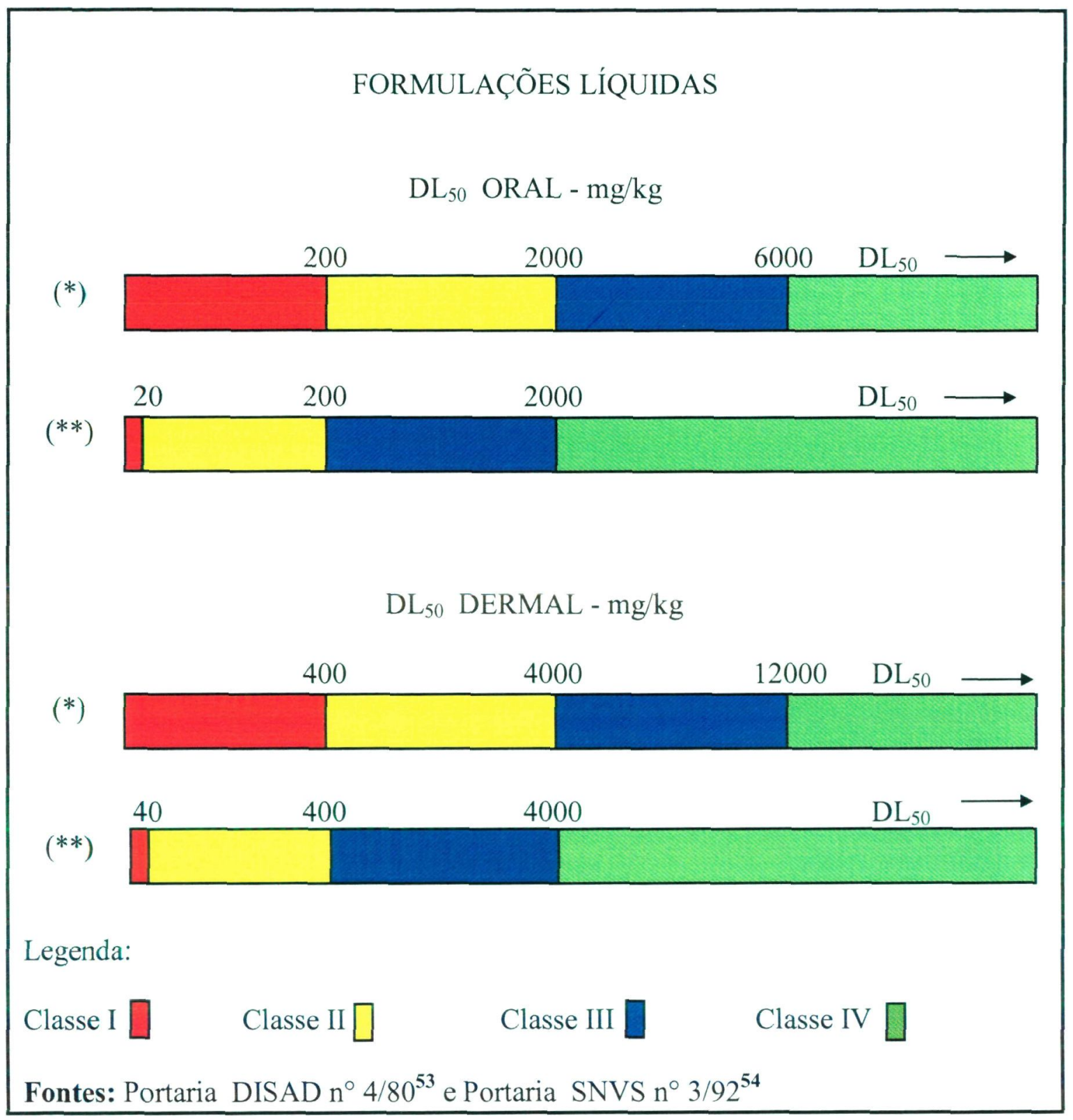

No caso das formulações líquidas (Figura 1) a reclassificação foi bastante expressiva, pois apenas uma pequena parcela da faixa da Classe I se manteve como tal, mudando a maior parte da faixa para a Classe II e as faixas das Classes II e III mudaram, respectivamente para III e IV. 
Figura 2 - Comparação entre as faixas de classificação toxicológica das Portarias DISAD $n^{0} 4 / 80\left({ }^{*}\right)$ e SNVS $n^{0} 3 / 92\left({ }^{* *}\right)$, para formulações sólidas.

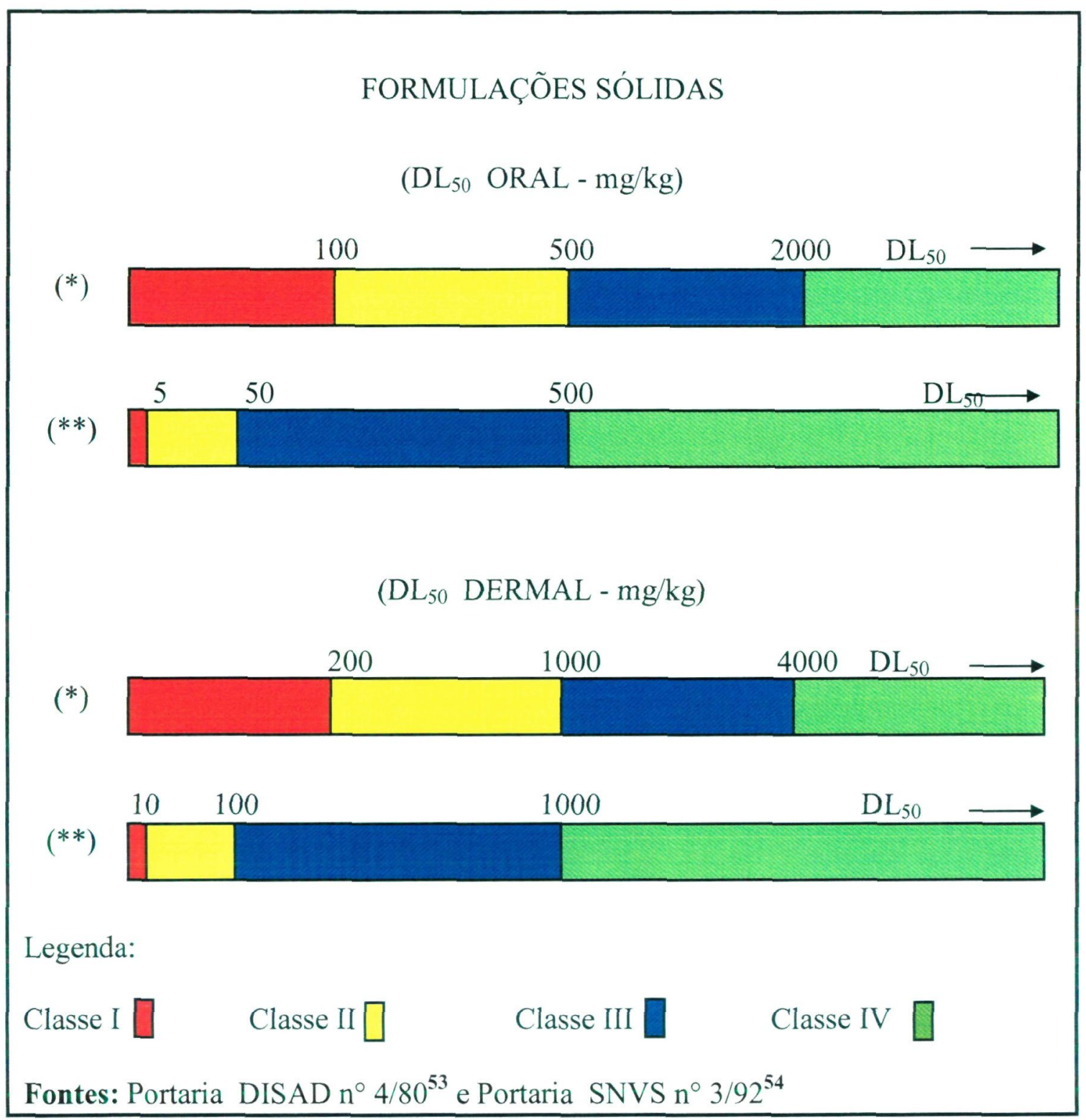

No caso das formulações sólidas (Figura 2) as mudanças foram ainda maiores. A faixa da Classe I foi dividida em três classes, ficando parte na mesma Classe I, outra parte passou a ser Classe II e ainda uma terceira parte se transformou em Classe III. Assim como ocorreu com as faixas das formulações líquidas, também nas sólidas as faixas das Classes II e III se transformaram em III e IV, respectivamente. 
Como se pode observar, as mudanças nos critérios de classificação toxicológica implicaram em grandes alterações no que se refere à comunicação de riscos na rotulagem dos agrotóxicos (faixas coloridas), o que pode ter ocasionado sérias conseqüências aos usuários dos agrotóxicos.

\subsection{A regulamentação no âmbito internacional}

A FAO, em seu Código Internacional de Conduta para a Distribuição $e$ Utilização de Agrotóxicos ${ }^{55}$, manifesta que: Vários países e organizações têm discutido a questão sobre se é justo disponibilizar agrotóxicos aos países que não têm infra-estrutura para registrá-los e garantir o seu uso seguro e eficaz. É preciso ressaltar que a elaboração de programas nacionais de regulamentação é a máxima prioridade das atividades da FAO neste setor.

Também a Organização Internacional do Trabalho - OIT - aborda a importância da legislação, de modo geral, e do registro, em particular, para que o trabalho com agrotóxicos seja mais seguro ${ }^{33}$ e salienta iniciativas recentes de vários países nesse sentido ${ }^{\mathbf{5 6}}$.

A Organização Mundial da Saúde ${ }^{80}$ - OMS - faz referência que nos paises desenvolvidos poucos compostos novos chegam anualmente ao mercado devido ao alto custo envolvido no desenvolvimento dessas substâncias para satisfazer as rígidas exigências sobre efeitos toxicológicos e ambientais. Em um estudo sobre o uso de agrotóxicos e seus impactos à saúde e ao ambiente no continente americano, a Organização Panamericana da Saúde ${ }^{58}$ recomenda a atualização e o fortalecimento da legislação existente na região.

Entre os países desenvolvidos, a preocupação com a necessidade de regulamentar as substâncias empregadas no controle de pragas e doenças na produção agrícola já ocorre há bastante tempo. Nos $\mathrm{EUA}^{39}$ a primeira regulamentaçã̃o específica sobre agrotóxicos data de 1910, estabelecendo padrões sobre a qualidade dos inseticidas e fungicidas. Mas foi em 1947 que a necessidade de registro para a comercialização dos agrotóxicos foi estabelecida pelo instrumento 
legal conhecido por FIFRA (Federal Insecticide, Fungicide and Rodenticide Act). Em 1970, com a crescente pressão da opinião pública sobre a necessidade da preservação ambiental, é criada a Agência de Proteção Ambiental (Environmental Protection Agency - EPA), que assume, entre outras, a responsabilidade pela regulamentação, avaliação e registro dos agrotóxicos.

A EPA desenvolveu procedimentos padrões para a realização dos testes e para a análise dos dados requeridos visando garantir a qualidade e a consistência dos estudos científicos solicitados. Um produto leva, no mínimo, de dois a três anos ${ }^{\mathbf{3 9}}$ para obter um registro nos EUA. A EPA trabalha com o conceito de beneficio-risco, ou seja, procura avaliar os riscos à saúde e ao ambiente da exposição ao produto contra os benefícios do seu uso para a sociedade e a economia. Mas, segundo Osteen $^{57}$, a idéia de que os riscos no uso de alguns agrotóxicos podem sobrepujar os seus benefícios mudou a política de regulamentação: reconhece-se o papel dos agrotóxicos na produção agrícola mas enfatiza-se a necessidade de proteção contra os riscos. O foco é retirar os agrotóxicos "inseguros" do mercado e agilizar a entrada de outros mais seguros. Dos 28 novos ingredientes ativos registrados em 1997 pela EPA, 19 foram considerados safer pesticides (biológicos e outros tipos de menor periculosidade à saúde e ao ambiente) ${ }^{5}$. Naquele ano havia aproximadamente 890 ingredientes ativos e 20.700 produtos formulados registrados nos EUA, que consumiu cerca de $1 / 3$ do valor de vendas mundiais ${ }^{5}$.

Nos países europeus ${ }^{78}$ os sistemas para avaliar a segurança e a eficácia dos agrotóxicos tem sido bastante aprimorados nas últimas 2 ou 3 décadas para atender as crescentes pressões políticas e da opinião pública e também em função do desenvolvimento científico das técnicas de avaliação de risco. Apesar disso, o grau das exigências para a avaliação e o registro varia entre os países, com a maioria das diferenças se dando principalmente nos aspectos relativos às questões ambientais, mas apresentando uma certa uniformidade quanto aos aspectos toxicológicos.

$\mathrm{Na}$ perspectiva de harmonizar exigências e procedimentos relacionados ao registro, a Comunidade Européia tem discutido diretrizes para a questão. A base do sistema de registro é uma lista onde constam os ingredientes ativos permitidos para 
registro pelos países membros, obtida pela implementação gradual dos procedimentos padrões da Comunidade, como por exemplo, a revisão sistemática dos cerca de 850 ingredientes ativos comercializados na União Européia ${ }^{23}$.

\subsection{Hipóteses}

Considerando os aspectos colocados nesta introdução, são apresentadas as seguintes hipóteses:

\section{Hipótese $\mathbf{n}^{0} 1$}

A legislação tem se tornado mais exigente quanto aos aspectos toxicológicos e ambientais avaliados no registro de agrotóxicos, mas o aumento no rigor das exigências não tem sido acompanhado da efetivação de mecanismos de controle dos impactos provocados por essas substâncias.

\section{Hipótese $\mathbf{n}^{0} 2$}

As alterações nos critérios de classificação toxicológica proporcionaram mudanças de Classes Toxicológicas de maior risco para classes de menor risco na maioria dos produtos registrados, implicando mudanças na comunicação de riscos utilizada nos rótulos que possibilitam o agravamento dos impactos provocados pelo uso dos agrotóxicos.

\section{Hipótese $\mathbf{n}^{0} 3$}

Considerando os argumentos de que os novos agrotóxicos sintetizados tendem a ser menos impactantes à saúde e ao ambiente e de que a "Lei dos Agrotóxicos" introduziu instrumentos que dificultariam o registro de substâncias de maior periculosidade, espera-se que haja diferenças entre a distribuição segundo a Classe Toxicológica dos ingredientes ativos registrados sob a antiga legislação e a dos que se encontram registrados sob a nova legislação, apontando para um aumento relativo de registro de substâncias nas classes de menor toxicidade. 


\section{Hipótese $n^{0} 4$}

As diferenças na distribuição, segundo a Classe Toxicológica, dos ingredientes ativos registrados sob a antiga legislação e a dos que se encontram registrados sob a nova legislação variam em função da Classe de Uso (inseticidas, fungicidas, herbicidas).

\section{Hipótese $\mathbf{n}^{\circ} 5$}

Como o interesse de substituição das substâncias de maior toxicidade pesa menos do que o interesse de mercado das empresas registrantes, o maior aumento relativo de registros de ingredientes ativos de menor toxicidade aguda, no período após a Lei dos Agrotóxicos, não se dá entre os inseticidas, classe que apresentava a maior proporção de produtos mais tóxicos antes da Lei.

\section{Hipótese no 6}

Considerando que o tempo de desenvolvimento e entrada de novas substâncias no mercado é relativamente longo, o registro de produtos comerciais derivados dos ingredientes ativos que já estavam registrados antes da "Lei dos Agrotóxicos" sobrepujam o registro de produtos derivados de "novos" ingredientes ativos, registrados após a Lei, apesar destes últimos serem, provavelmente, de menor impacto à saúde.

\section{Hipótese $\mathbf{n}^{\circ} 7$}

Devido aos interesses de mercado, as culturas que são maiores consumidoras de agrotóxicos recebem maior número de registros.

\section{Hipótese $\mathbf{n}^{\circ} 8$}

Embora a legislação em vigor só permita o registro de um agrotóxico se a sua toxicidade para o ser humano e o ambiente for comprovadamente igual ou menor do que aqueles já registrados para a mesma finalidade, há registros de produtos 
comerciais de maior toxicidade aguda que outros já registrados para a mesma finalidade. 


\section{OBJETIVOS}

\subsection{Objetivo Geral:}

Avaliar as conseqüências da aplicação da "Lei dos Agrotóxicos" e respectiva regulamentação na classificação toxicológica e de potencial de periculosidade ambiental dos agrotóxicos registrados e no número de casos notificados de intoxicações agudas, no Brasil, visando analisar o registro de agrotóxicos como instrumento de controle dos impactos provocados por essas substâncias à saúde $\mathrm{e}$ ao ambiente e contribuir com sugestões para o aperfeiçoamento da política de controle dos agrotóxicos no Brasil.

\subsection{Objetivos Específicos}

\section{Objetivo específico $\mathbf{n}^{\circ} 1$}

Avaliar a série histórica do total de casos anuais de intoxicações agudas ocasionadas por agrotóxicos, registradas pelo Sistema Nacional de Informações Tóxico-Farmacológicas, e sua relação com as vendas anuais de agrotóxicos, no Brasil, no período de 1985 a 1999, visando observar possível influência da "Lei dos Agrotóxicos" nessa evolução.

\section{Objetivo específico $n^{0} 2$}

Estimar as conseqüências da mudança dos critérios de classificação toxicológica promovida pela regulamentação da "Lei dos Agrotóxicos" (Portaria SNVS n 3/92) na reclassificação toxicológica dos produtos comerciais que se encontravam registrados na época da alteração, verificando as prováveis modificações na distribuição dos mesmos segundo a Classe Toxicológica e discutindo os possíveis impactos dessas mudanças na saúde pública, em especial na saúde do trabalhador.

\section{Objetivo específico $n^{\circ} 3$}

Comparar a distribuição, segundo a Classe Toxicológica, dos ingredientes ativos que foram registrados sob a vigência do Decreto $n^{\circ} 24.114 / 34$ e estavam 
registrados em 1990, com os que estavam registrados sob a vigência da Lei 7.802/89 ("Lei dos Agrotóxicos") em 2000, a fim de verificar se existem diferenças nas classes de inseticida, fungicida e herbicida e no total dos produtos registrados.

\section{Objetivo específico $n^{\circ} 4$}

Analisar a distribuição dos produtos comerciais registrados sob a vigência da "Lei dos Agrotóxicos", considerando o período 1990-2000, em termos de época de registro do ingrediente ativo e segundo a Classe de Uso (inseticidas, fungicidas, herbicidas e "outros"), a Classe Toxicológica e a Classe de Potencial de Periculosidade Ambiental, a fim de verificar se existem diferenças entre os produtos originários de ingredientes ativos "antigos", registrados antes da Lei, e os derivados dos ingredientes ativos "novos", registrados após a Lei.

\section{Objetivo específico $n^{\circ} 5$}

Analisar a distribuição dos produtos comerciais que foram registrados sob a vigência da "Lei dos Agrotóxicos" e estavam registrados no ano 2000 quanto às culturas/produtos de destinação para os quais foram permitidos, segundo a Classe de Uso (inseticidas, fungicidas, herbicidas e "outros"), a Classe Toxicológica e a Classe de Potencial de Periculosidade Ambiental, a fim de verificar a proporção de produtos registrados em cada classe e as diferenças entre as culturas/produtos de destinação.

\section{Objetivo específico $n^{0} 6$}

Analisar a distribuição dos produtos comerciais registrados sob a vigência da "Lei dos Agrotóxicos", considerando o período 1990-2000, para a finalidade de controle do Aphis gossypii (pulgão do algodoeiro), em termos de época de registro do ingrediente ativo e segundo a Classe Toxicológica, como estudo de caso do comportamento dos registros efetuados para uma mesma finalidade. 


\section{MÉTODOS}

\subsection{Aspectos metodológicos gerais}

Para a consecução dos objetivos se fez necessário o uso de dados referentes aos agrotóxicos registrados. Foram formados cinco bancos de dados: três deles relacionados entre si e dois outros independentes.

Para a geração dos bancos de dados foi utilizado o software EPI INFO ${ }^{19}$ (versão 6.04b). A estruturação dos bancos e a alimentação dos dados foram feitas por apenas uma pessoa (o autor), evitando duplicidade de interpretações. Foram preenchidos mais de 30.000 campos. Mecanismos de checagem de entrada de dados disponíveis no software foram empregados para controlar eventuais erros de digitação.

Os três bancos relacionados foram elaborados e alimentados com as seguintes informações:

\section{Banco 1 - Ingrediente Ativo - 367 registros, cada um contendo (anexo 1):}

- nome técnico ou comum;

- confirmação de registro em 1990 e 2000;

- Classe de Uso

- inseticida $\Rightarrow$ inclui: inseticidas, acaricidas, formicidas, fumigantes, moluscicidas, nematicidas;

- fungicida $\Rightarrow$ inclui: fungicidas, antibióticos, bactericidas;

- herbicida $\Rightarrow$ inclui: herbicidas, dessecantes;

- "outros" $\Rightarrow$ inclui: adjuvantes, antibrotantes, espalhantes adesivos, estimulantes, feromônios, reguladores de crescimento, surfactantes agrícolas.

- Classe de Periculosidade, de acordo com a classificação da OMS constante na publicação The WHO recommended classification of pesticides by hazard and guidelines to classification, edição 1990-1991 ${ }^{81}$ (para os produtos que 
estavam registrados em 1990) e edição 1998-199982 (para os produtos que estavam registrados em 2000);

- Classe Toxicológica, de acordo com a classificação do Ministério da Saúde ${ }^{\mathbf{5 0}}$;

\section{Banco 2 - Produto Comercial - 1.045 registros, cada um contendo (anexo 2):}

- marca comercial;

- confirmação de registro em 1990 e 2000;

- Classe de Uso

- inseticida $\Rightarrow$ inclui: inseticidas, acaricidas, formicidas, fumigantes, moluscicidas, nematicidas;

- fungicida $\Rightarrow$ inclui: fungicidas, antibióticos, bactericidas;

- herbicida $\Rightarrow$ inclui: herbicidas, dessecantes;

- "outros" $\Rightarrow$ inclui: adjuvantes, antibrotantes, espalhantes adesivos, estimulantes, feromônios, reguladores de crescimento, surfactantes agrícolas.

- Classe Toxicológica, de acordo com o Compêndio de Defensivos Agrícolas ${ }^{4}$, $3^{a}$ edição, 1990, para os produtos que estavam registrados em 1990, e o programa $A G R O F I T / 98^{48}$, do Ministério da Agricultura, complementado com informações do programa $A$ GROTIS ${ }^{1}$ (atualização de Fevereiro/2000), para os produtos que estavam registrados em 2000;

- Classe de Potencial de Periculosidade Ambiental, de acordo com o programa $A G R O F I T / 98^{48}$, do Ministério da Agricultura, complementado com informações do IBAMA *

\section{Banco 3 - Culturas/produtos de destinação - 6.864 registros, cada um contendo:}

- uma cultura ou produto de destinação para o qual o produto comercial teve uso permitido (cada destinação equivale a um registro);

\footnotetext{
$O$ arquivo contendo as informações de classificação de potencial periculosidade ambiental dos produtos registrados pelo Ministério da Agricultura e avaliados ambientalmente pelo IBAMA nos foi disponibilizado por correio eletrônico procedente deste órgão, em 18/09/2000.
} 
A seguir, apresentamos a relação de informações constantes nos bancos independentes.

Banco 4 - Dados para avaliar mudanças na classificação toxicológica - 584 registros, cada um contendo (os dados sublinhados constam do anexo 3):

- marca comercial;

- confirmação de registro em 1990 e 2000;

- Classe de Uso

- inseticida $\Rightarrow$ inclui: inseticidas, acaricidas, formicidas, fumigantes, moluscicidas, nematicidas;

- fungicida $\Rightarrow$ inclui: fungicidas, antibióticos, bactericidas;

- herbicida $\Rightarrow$ inclui: herbicidas, dessecantes;

- "outros" $\Rightarrow$ inclui: adjuvantes, antibrotantes, espalhantes adesivos, estimulantes, feromônios, reguladores de crescimento, surfactantes agrícolas.

- identificação de misturas de ingredientes ativos;

- formulação do produto;

- rota de exposição dos ensaios toxicológicos de $\mathrm{DL}_{50}$ (oral, dermal)

- Classe Toxicológica anterior à Portaria 3/92, de acordo com o Compêndio de Defensivos Agrícolas ${ }^{4}, 3^{\text {a }}$ edição, 1990;

- Classe Toxicológica posterior à Portaria 3/92, de acordo com o programa AGROFIT/9 $8^{48}$, do Ministério da Agricultura, complementado com informações do programa AGROTIS ${ }^{1}$ (atualização de Fevereiro/2000);

- Classe Toxicológica anterior e posterior à Portaria 3/92, determinadas de acordo com metodologia da Organização Mundial da Saúde ${ }^{81,82}$;

- Classe Toxicológica posterior à Portaria 3/92, de acordo com informações do Ministério da Saúde.

$\mathrm{O}$ arquivo contendo as informações de classificação toxicológica dos produtos registrados pelo Ministério da Agricultura e avaliados toxicológicamente pelo Ministério da Saúde nos foi disponibilizado por correio eletrônico procedente deste órgão, em 18/09/2000. 
- $\mathrm{DL}_{50}$ dos produtos comerciais registrados, de acordo com o programa $A G R O T I S^{1}$ e estimada de acordo com metodologia da Organização Mundial da Saúde ${ }^{81,82}$;

- ingrediente(s) ativo(s) que compõe(m) o produto comercial;

- concentração do(s) ingrediente(s) ativo(s) que compõe(m) o produto comercial;

\section{Banco 5 - Dados sobre produtos registrados para controle do "pulgão do} algodoeiro" - 117 registros, cada um contendo (anexo 4):

- marca comercial;

- confirmação de registro do produto comercial em 1990 e 2000;

- confirmação de registro do ingrediente ativo em 1990 e 2000;

- Classe Toxicológica, de acordo com o Compêndio de Defensivos Agrícolas ${ }^{4}$, $3^{a}$ edição, 1990, para os produtos que estavam registrados em 1990, e o programa $A G R O F I T / 98^{48}$, do Ministério da Agricultura, complementado com informações do programa $A G R O T S^{1}$ (atualização de Fevereiro/2000), para os produtos que estavam registrados em 2000;

As informações básicas necessárias para a formação dos bancos de dados foram provenientes das seguintes fontes:

- Compêndio de Defensivos Agrícolas ${ }^{4}$ - Publicação da Organização Andrei Editora Ltda., periodicamente atualizada, que reúne as informações contidas nos rótulos de todos os agrotóxicos comerciais registrados. Até o aparecimento dos sistemas informatizados era uma das únicas fontes que congregava informações técnicas básicas sobre as características e recomendações relativas aos agrotóxicos registrados. A edição de 1990 ( $3^{\text {a }}$ edição) foi utilizada para identificar os produtos que se encontravam registrados antes da regulamentação da "Lei dos Agrotóxicos" e como fonte de algumas das informações técnicas necessárias a este estudo. 
- The WHO recommended classification of pesticides by hazard and guidelines to classification $1990-1991^{81}$ e $1998-1999^{82}$ - Aprovada pela OMS desde 1975, recomendada pela FAO e adotada pelo Conselho da Europa e diversos países. A classificação se baseia na toxicidade aguda oral e dermal para ratos $\left(\mathrm{DL}_{50}\right)$ do ingrediente ativo (grau técnico) e suas formulações e classifica cada substância em uma das 3 classes (e duas sub-classes) de periculosidade à saúde propostas. Permite estimar a classe do produto comercial a partir da concentração do ingrediente ativo na formulação. Passa por revisões periódicas.

- AGROFIT/98 ${ }^{48}$ - Base de dados oficial, produzida pelo Ministério da Agricultura e Abastecimento. A base de dados tem por finalidade auxiliar na indicação de agrotóxicos para fins fitossanitários e permite consultas a partir do produto comercial, do ingrediente ativo, da cultura ou das pragas e doenças. Contém informações sobre o número do registro, o nome comum, o grupo químico, o nome químico, a fórmula bruta, a concentração do ingrediente ativo, a Classe Toxicológica, a Classe de Potencial de Periculosidade Ambiental, a Classe de Uso, o tipo de formulação, as culturas e finalidades (pragas e doenças), as doses recomendadas, os métodos de aplicação recomendados, o intervalo de segurança (tempo a ser respeitado entre a última aplicação do agrotóxico e a colheita ou comercialização do produto agrícola) entre outras informações. A base de dados não permite a elaboração de listagens ou análises quantitativas sobre as informações que contém, como saber quantos produtos de cada Classe Toxicológica estão registrados, por exemplo.

- AGROTIS - Sistema de Receituário Agronômico ${ }^{1}$ - Banco de dados desenvolvido por uma empresa privada de consultoria agronômica com a finalidade de facilitar o acesso aos dados necessários para o uso de agrotóxicos e para a elaboração do receituário agronômico. Mensalmente atualizado, contém informações sobre os agrotóxicos comerciais que se encontram disponiveis no mercado, incluindo, a $\mathrm{DL}_{50}$, a Classe Toxicológica, as culturas e finalidades (pragas e doenças) e as doses recomendadas, entre outras. Permite a 
obtenção de algumas listagens organizadas segundo determinadas informações, como por ordem de classificação toxicológica, por exemplo.

- Órgãos registrantes - Informações sobre a classificação toxicológica das substâncias registradas foram obtidas diretamente no site da Agência Nacional de Vigilância Sanitária - ANVISA ${ }^{50}$. Os dados de classificação toxicológica e de classificação de potencial de periculosidade ambiental dos produtos comerciais registrados foram solicitados e obtidos diretamente junto aos órgãos responsáveis pelas mesmas, respectivamente, ANVISA e IBAMA.

A consulta a várias fontes se deu, especialmente, pela dificuldade em obter as informações necessárias ao estudo. Desatualização, falta de dados, inconsistências, discrepâncias entre fontes, ausência de padronizações, entre outros aspectos, impossibilitaram o uso de apenas uma fonte e determinaram a necessidade de formar os bancos.

\subsection{Aspectos metodológicos específicos}

\section{Objetivo específico $\mathbf{n}^{0} \mathbf{1}$}

Para avaliar a evolução das ocorrências de casos registrados de intoxicações agudas ocasionadas por agrotóxicos no Brasil e a possível influência da aplicação da "Lei dos Agrotóxicos" nessa evolução optou-se por analisar a correlação entre as vendas de agrotóxicos e o registro de casos de intoxicação no país nos períodos imediatamente anterior e posterior à Legislação. Em função da disponibilidade dessas informações, originárias respectivamente da ANDEF/SINDAG e do SINITOX, foi analisado o período de 1985 a 1999.

Para essa finalidade utilizou-se o Coeficiente de correlação linear de Pearson $^{17}$, que varia entre $-1 \mathrm{e}+1$, sendo $\mathrm{r}=-1$ equivalente à correlação linear negativa perfeita e $\mathrm{r}=+1$ à correlação linear positiva perfeita, facilitando também a interpretação de valores intermediários. A partir do resultado obtido, buscou-se um 
modelo de Regressão Linear Simples ${ }^{17}$, definindo como variável dependente (y) o número de casos anuais de intoxicações por agrotóxicos registrados pelo Sistema Nacional de Informações Tóxico-Farmacológicas - SINITOX - do Ministério da Saúde, e como variável independente (x) o valor de vendas anuais de agrotóxicos divulgado pela Associação Nacional de Defesa Vegetal - ANDEF e SINDAG, com o seguinte modelo:

Casos de intoxicação registrados $=\mathrm{b} \times$ valor de vendas (US\$ 1,000.00)

Foi realizado o cálculo estimativo do valor de "b" (coeficiente de regressão linear), permitindo com esta equação estimar o número de intoxicações que seriam registradas dado um determinado valor de vendas.

\section{Objetivo específico $\mathrm{n}^{0} 2$}

A mudança nos parâmetros de classificação toxicológica se deu pela edição da Portaria SNVS $n^{\circ} 3 / 92^{54}$, que estabeleceu os novos critérios e revogou a Portaria DISAD $\mathrm{n}^{\circ} 4 / 80^{53}$, que anteriormente regulamentava a questão. A avaliação estimativa do impacto dessa mudança na reclassificação toxicológica dos produtos comerciais registrados foi obtida como segue:

a) devido às dificuldades para obtenção de informações referentes aos produtos que se encontravam registrados no momento das alterações dos critérios da classificação toxicológica, para fins deste estudo, foram considerados produtos comerciais que sofreram alteração de Classe Toxicológica aqueles que constavam do Compêndio de Defensivos Agricolas ${ }^{4}, 3^{a}$ edição, 1990 e cuja $\mathrm{DL}_{50}$ do ingrediente ativo constava do documento The WHO recommended classification of pesticides by hazard and guidelines to classification 1990$1991^{81}$.

b) devido à desatualização e diferenças entre as fontes de informação que deveriam conter a Classe Toxicológica dos produtos comerciais, optou-se por determinar a Classe Toxicológica de cada produto calculando a correspondente 
classe de periculosidade da OMS; para isso utilizou-se a metodologia proposta pela própria $\mathrm{OMS}^{81}$, que estabelece a classe de periculosidade com base na $\mathrm{DL}_{50} \mathrm{do}(\mathrm{s})$ ingredientes ativos(s) e sua(s) concentração(ões) na formulação, estimando o valor da $\mathrm{DL}_{50}$ do produto comercial por meio da seguinte fórmula:

\section{DL50 do ingrediente ativo $\times 100$}

Porcentagem do ingrediente ativo na formulação

c) embora na legislação brasileira a classificação toxicológica possa ser definida por outros dados além da $\mathrm{DL}_{50}$, para fins deste estudo, onde a idéia foi procurar mostrar o impacto potencial de uma mudança como a ocorrida nos critérios relacionados à $\mathrm{DL}_{50}$ para a classificação toxicológica, os dados de $\mathrm{DL}_{50}$ calculados pelo método da OMS foram utilizados para determinar as Classes Toxicológicas anteriores (Portaria DISAD $n^{\circ} 4 / 80^{53}$ ) e posteriores às mudanças de critérios (Portaria SNVS $n^{\circ} 3 / 92^{54}$ ).

d) Para verificar se houve diferença estatística entre as distribuições da classificação toxicológica dos produtos comerciais que se encontravam registrados antes e após à mudança de critérios, foi empregado o teste de QuiQuadrado de Tendência em Dados Ordenáveis ${ }^{66}$, utilizando o programa SAS ${ }^{65}$ (versão 8), apresentando as seguintes hipóteses para cada Classe de Uso (inseticida, fungicida, herbicida, "outros" e total dos produtos registrados) e considerando um nível de significância $\mathrm{p} \leq 0,05$ :

$\mathrm{h}_{\mathrm{o}}$ : as duas distribuições são semelhantes.

$h_{\mathrm{a}}:$ as duas distribuições são diferentes.

e) para testar a concordância entre a classificação toxicológica anterior e a posterior à mudança de critérios foi utilizado o Coeficiente de Kappa (COHEN, $1960)^{14}$, que pode variar de $-1,00$ a $+1,00$. Para interpretar a relação de concordância dos resultados foi empregada a escala proposta por LANDIS \& KOCH (1977) ${ }^{\mathbf{4 0}}$ : 


$$
\begin{aligned}
<0,00 & =\text { ruim } \\
0,00 \text { a } 0,20 & =\text { baixa; } \\
0,21 \text { a } 0,40 & =\text { regular; } \\
0,41 \text { a } 0,60 & =\text { moderada } \\
0,61 \text { a } 0,80 & =\text { substancial } \\
0,81 \text { a } 1,00 & =\text { quase perfeita }
\end{aligned}
$$

\section{Objetivo específico $\mathrm{n}^{\circ} 3$}

A comparação da distribuição, segundo a Classe Toxicológica, dos ingredientes ativos que foram registrados sob a vigência do Decreto $n^{\circ} 24.114 / 34$ e estavam registrados em 1990, com os que estavam registrados sob a vigência da Lei 7.802/89 ("Lei dos Agrotóxicos") em 2000, nas classes de inseticida, fungicida e herbicida e no total dos produtos registrados foi obtida como segue:

a) a identificação dos ingredientes ativos que estavam registrados em 1990 foi feita utilizando-se como base o Compêndio de Defensivos Agricolas $^{4}, 3^{\text {a }}$ edição, 1990; algumas correções tiveram que ser realizadas, devido à duplicidade de nomes para uma mesma substância (ex.: fenbutatin oxide = óxido de fenibutatina), e também algumas adequações, especialmente na formação de agrupamentos de substâncias sob um mesmo nome geral de ingredientes ativos (ex.: 2,4-D);

b) a identificação dos ingredientes ativos que estavam registrados em 2000 foi feita utilizando-se como base o programa $A G R O F I T / 98^{48}$, do Ministério da Agricultura, complementada com informações do programa AGROTIS ${ }^{1}$ (atualização de Fevereiro/2000) e das Monografias de Produtos Agrotóxicos ${ }^{50}$ disponibilizadas pelo Ministério da Saúde.

c) foram considerados novos ingredientes ativos registrados sob a vigência da Lei 7802/89, "Lei dos Agrotóxicos", aqueles que constavam do programa AGROFIT $/ 98^{48}$, do Ministério da Agricultura (complementados com informações do programa AGROTIS ${ }^{1}$ - atualização de Fevereiro/2000 - e das Monografias de 
Produtos Agrotóxicos ${ }^{50}$ disponibilizadas pelo Ministério da Saúde) e não constavam do Compêndio de Defensivos Agricolas ${ }^{4}, 3^{\text {a }}$ edição, 1990.

d) Para a comparação entre os ingredientes ativos que estavam registrados em 1990 com os que estavam registrados em 2000, em cada Classe de Uso (inseticida, fungicida, herbicida, "outros") e no total dos produtos registrados, para fins de padronização, foi empregada a classificação de periculosidade (risco agudo à saúde) da OMS (The WHO recommended classification of pesticides by hazard and guidelines to classification 1990-1991 ${ }^{81}$ e 1998-199982);

e) os dados referentes aos novos ingredientes ativos, classificados sob a vigência da Lei 7802/89, foram estudados e apresentados segundo a Classe de Periculosidade obtida junto à classificação da OMS (The WHO recommended classification of pesticides by hazard and guidelines to classification 1996-1997 $7^{81}$ ) e a Classe Toxicológica foi obtida junto aos programas AGROFIT, AGROTIS e ao Ministério da Saúde;

f) Para verificar se houve diferença estatística entre as distribuições foi empregado o teste de Qui-Quadrado de Tendência em Dados Ordenáveis ${ }^{66}$, utilizando o programa $S A S^{65}$ (versão 8 ), apresentando as seguintes hipóteses e considerando um nível de significância $\mathrm{p} \leq 0,05$ :

$$
\begin{aligned}
& \mathrm{h}_{\mathrm{o}} \text { : as duas distribuições são semelhantes. } \\
& \mathrm{h}_{\mathrm{a}}: \text { as duas distribuições são diferentes. }
\end{aligned}
$$

g) o teste de Qui-Quadrado de Tendência em Dados Ordenáveis ${ }^{\mathbf{6 6}}$ foi aplicado considerando somente os dados referentes às substâncias que constavam das classificações da OMS (The WHO recommended classification of pesticides by hazard and guidelines to classification $1990-1991^{81}$ e $1998-1999^{82}$ ).

h) a análise estatística comparativa da classificação toxicológica (Ministério da Saúde) e de periculosidade (Organização Mundial da Saúde) dos ingredientes ativos foi realizada aplicando-se o teste do coeficiente de Kappa (COHEN, 
$1960)^{14}$, que pode variar de $-1,00$ a $+1,00$. Para interpretar a relação de concordância dos resultados foi empregada a escala proposta por LANDIS \& KOCH (1977) ${ }^{\mathbf{4 0}}$ :

$$
\begin{aligned}
<0,00 & =\text { ruim } ; \\
0,00 \text { a } 0,20 & =\text { baixa } \\
0,21 \text { a } 0,40 & =\text { regular; } \\
0,41 \text { a } 0,60 & =\text { moderada } \\
0,61 \text { a } 0,80 & =\text { substancial } \\
0,81 \text { a } 1,00 & =\text { quase perfeita }
\end{aligned}
$$

\section{Objetivo específico $n^{\circ} 4$}

A identificação dos produtos comerciais registrados sob a vigência da "Lei dos Agrotóxicos", e a análise da distribuição desses novos registros em termos de época de registro do ingrediente ativo e segundo a Classe de Uso (inseticidas, fungicidas, herbicidas e outros), Classificação Toxicológica e Classificação de Periculosidade Ambiental foram realizadas como segue:

a) foram considerados produtos comerciais registrados sob a "Lei dos Agrotóxicos" aqueles que constavam do programa AGROFIT $/ 98^{48}$, do Ministério da Agricultura, complementando com informações do programa AGROTIS $^{1}$ (atualização de Fevereiro/2000), e não constavam do Compêndio de Defensivos Agricolas ${ }^{4}, 3^{a}$ edição, 1990.

b) os dados referentes às características dos novos agrotóxicos foram estudados e apresentados separadamente para os produtos comerciais derivados dos novos ingredientes ativos, para os novos produtos comerciais derivados dos ingredientes ativos que já estavam registrados em 1990 e para o total dos dados desses novos produtos comerciais;

c) Para verificar se houve diferença estatística entre as distribuições foi empregado o teste de Qui-Quadrado de Tendência em Dados Ordenáveis ${ }^{66}$, 
utilizando o programa $\mathrm{SAS}^{65}$ (versão 8), apresentando as seguintes hipóteses e considerando um nível de significância $p \leq 0,05$ :

$$
\begin{aligned}
& h_{0}: \text { as duas distribuições são semelhantes. } \\
& h_{a}: \text { as duas distribuições são diferentes. }
\end{aligned}
$$

\section{Objetivo específico $n^{\circ} 5$}

A identificação dos produtos comerciais registrados sob a vigência da "Lei dos Agrotóxicos" e a análise da distribuição desses novos registros em termos de culturas/produtos de destinação e respectivas Classe de Uso (inseticidas, fungicidas, herbicidas e outros), Classe Toxicológica e Classe de Potencial de Periculosidade Ambiental foram realizadas como segue:

a) foram considerados produtos comerciais registrados sob a "Lei dos Agrotóxicos" aqueles que constavam do programa AGROFIT/9 $8^{48}$, do Ministério da Agricultura, complementando com informações do programa AGROTIS ${ }^{1}$ (atualização de Fevereiro/2000), e não constavam do Compêndio de Defensivos Agrícolas ${ }^{4}, 3^{\text {a }}$ edição, 1990.

b) os dados referentes à destinação dos agrotóxicos registrados sob a vigência da "Lei dos Agrotóxicos" foram estudados segundo a distribuição dos produtos pelas diferentes culturas/produtos de destinação e suas proporções nas respectivas Classes de Uso, Classes Toxicológicas e Classes de Periculosidade Ambiental.

\section{Objetivo específico $n^{\circ} 6$}

Considerando a importância da cultura do algodão como uma das maiores consumidoras de agrotóxicos e também por ser identificada como uma das principais culturas associadas a casos de intoxicações de trabalhadores rurais, e tendo em vista que o "pulgão do algodoeiro" (Aphis gossypii) é uma das principais pragas da 
cultura e possui um relativo grande número de produtos comerciais registrados para o seu controle, foram trabalhados dados referentes aos produtos comerciais registrados para esse fim como estudo de caso do comportamento da classificação toxicológica dos registros efetuados para uma mesma finalidade sob a vigência da "Lei dos Agrotóxicos", como segue:

a) foram considerados produtos comerciais que estavam registrados imediatamente antes da "Lei dos Agrotóxicos" para o controle do "pulgão do algodoeiro" aqueles que constavam do Compêndio de Defensivos Agricolas ${ }^{4}, 3^{\mathrm{a}}$ edição, 1990;

b) foram considerados produtos comerciais registrados sob a "Lei dos Agrotóxicos" aqueles que constavam do programa AGROFIT/ $98^{48}$, do Ministério da Agricultura, complementando com informações do programa AGROTIS $^{1}$ (atualização de Fevereiro/2000), e não constavam do Compêndio de Defensivos Agrícolas ${ }^{4}, 3^{\text {a }}$ edição, 1990.

d) os dados foram analisados comparando-se a classificação toxicológica dos produtos comerciais derivados dos "novos" ingredientes ativos, registrados no período após a Lei, com a dos produtos comerciais derivados dos ingredientes ativos "antigos", que já estavam registrados antes da Lei, e com o total dos dados desses produtos comerciais;

e) Para verificar se houve diferença estatística entre as distribuições foi empregado o teste de Qui-Quadrado de Tendência em Dados Ordenáveis ${ }^{\mathbf{6 6}}$, utilizando o programa SAS ${ }^{65}$ (versão 8), apresentando as seguintes hipóteses e considerando um nível de significância $\mathrm{p} \leq 0,05$ :

$\mathrm{h}_{\mathrm{o}}$ : as duas distribuições são semelhantes.

$h_{\mathrm{a}}$ : as duas distribuições são diferentes. 


\section{RESULTADOS}

\section{Objetivo específico $\mathrm{n}^{0} 1$}

Uma das formas de avaliar o impacto da "Lei dos Agrotóxicos" seria pela análise de dados epidemiológicos de ocorrências de agravos à saúde humana ocasionados por exposição aos agrotóxicos. No entanto, há uma enorme carência de informações nessa área, provocada por incapacidade técnica e deficiências institucionais que dificultam a geração e o controle dessa informação. Mas alguma inferência pode ser feita, principalmente no que se refere aos casos de intoxicações agudas, pois alguns dados são disponíveis.

Uma das únicas fontes onde poderia ser obtida uma série histórica que contivesse dados nacionais de ocorrência de intoxicações por agrotóxicos, anteriores e posteriores à Lei, é o Sistema Nacional de Informações Tóxico-Farmacológicas SINITOX - do Ministério da Saúde. Como os casos registrados pelo SINITOX eram ano a ano crescentes e os dados de vendas de agrotóxicos também indicavam crescimento contínuo, optou-se por verificar a correlação entre eles. Assim, comparamos o comportamento do registro de casos de intoxicação ao comportamento das vendas de agrotóxicos no país, como mostra a Figura 3. 
Figura 3 - Vendas de agrotóxicos e casos de intoxicações por pesticidas agropecuários registrados pelo SINITOX*, no Brasil, no período de 1985 a 1999.

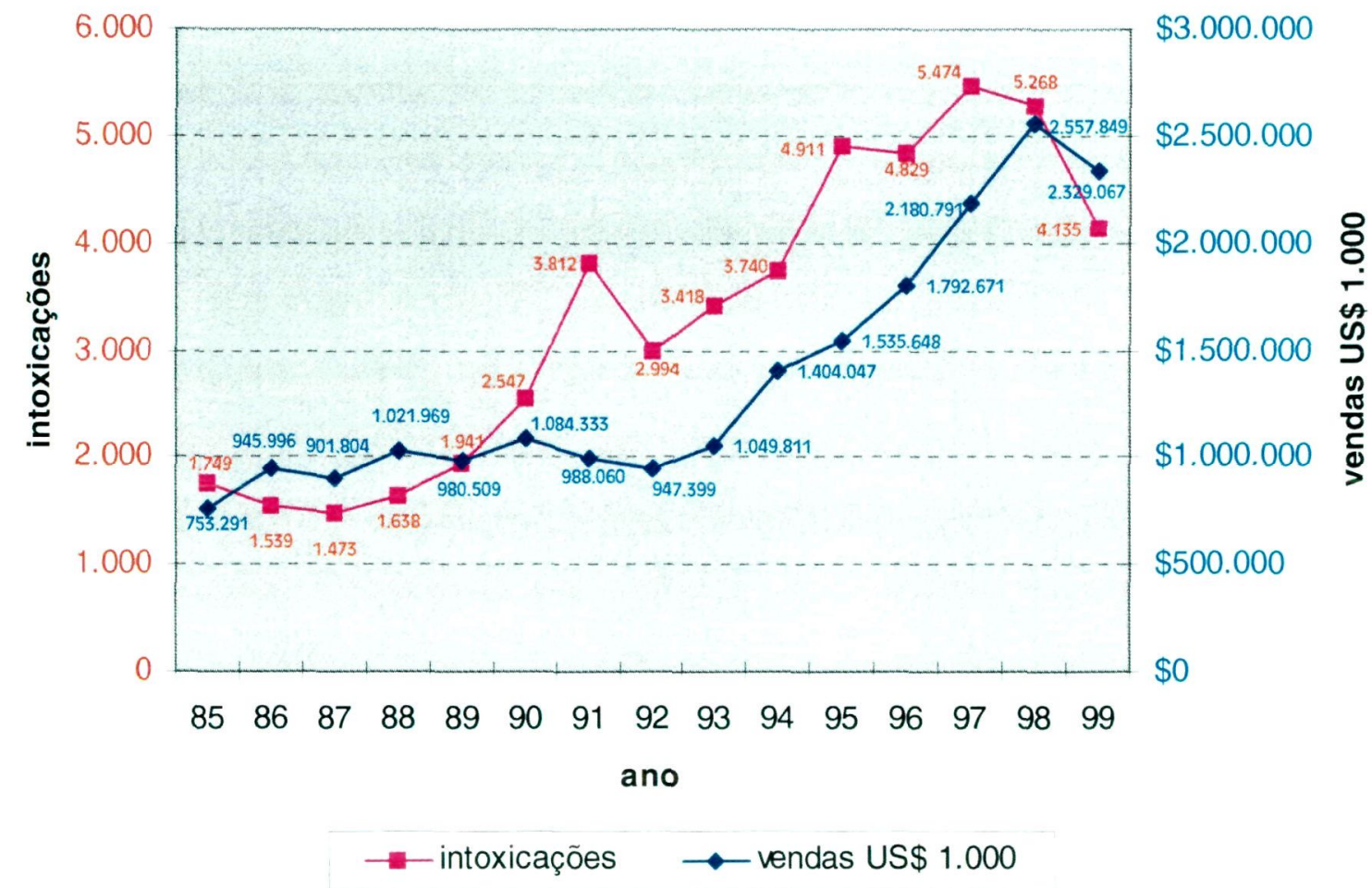

Fontes: Vendas - Futino e Silveira ${ }^{25}$; ANDEF $^{6}$; SINDAG $^{69}$.

Intoxicações - Bortoleto e col. ${ }^{8}$; SINITOX ${ }^{70,71,72,73,74,75,76}$

A análise da correlação entre as vendas de agrotóxicos e a ocorrência de intoxicações pelo Coeficiente de correlação linear de Pearson ${ }^{17,65}$ mostrou uma alta correlação positiva $(r=0,82065)$, estatisticamente significativa $(p<0,0001)$.

Buscou-se, então, por meio de Regressão Linear Simples ${ }^{17}{ }^{65}$, obter um modelo estatístico que descrevesse essa relação. 
A Figura 4 mostra o diagrama de dispersão dos dados trabalhados.

Figura 4 - Diagrama de dispersão das vendas de agrotóxicos e casos de intoxicações por pesticidas agropecuários, no Brasil, no período de 1985 a 1999.

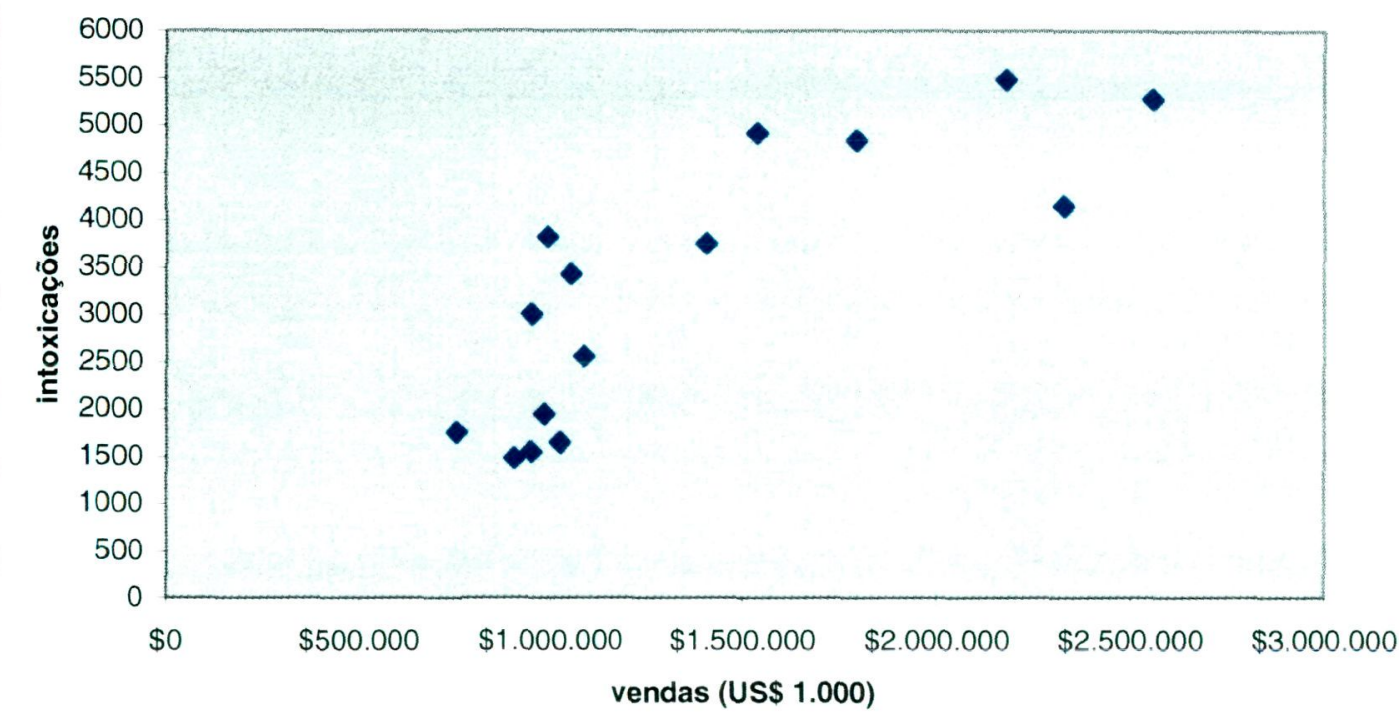

Fontes: Vendas - Futino e Silveira ${ }^{25} ; \mathrm{ANDEF}^{6} ; \mathrm{SINDAG}^{69}$. Intoxicações - Bortoleto e col. ${ }^{8}$; SINITOX ${ }^{70,71,72,73,74,75,76}$

A Figura 5 mostra o modelo ajustado. Obteve-se a seguinte equação (coeficiente de determinação $\mathrm{R}^{2}=0,9477$; estimador $\beta 1=0,00236$; $\mathrm{S}=0,00014814$ )

casos de intoxicação registrados $=0,00236 \times$ valor de vendas (US\$ $1,000.00$ )

e respectivo Intervalo de Confiança :

$$
\text { IC }(95 \%)=\text { estimador } \pm \mathrm{t}(\mathrm{n}-1,1-\alpha) \times S \quad \Rightarrow
$$

IC $(95 \%) \Rightarrow$ intox $=[0,00236 \pm 2,145 \times 0,00014814] \times$ valor de vendas (US\$ $1,000.00)$

A análise de variância (anova) indicou que o modelo proposto tem ajuste linear e é estatisticamente significativo $(F=253,48$ e $p<0,0001)$, 


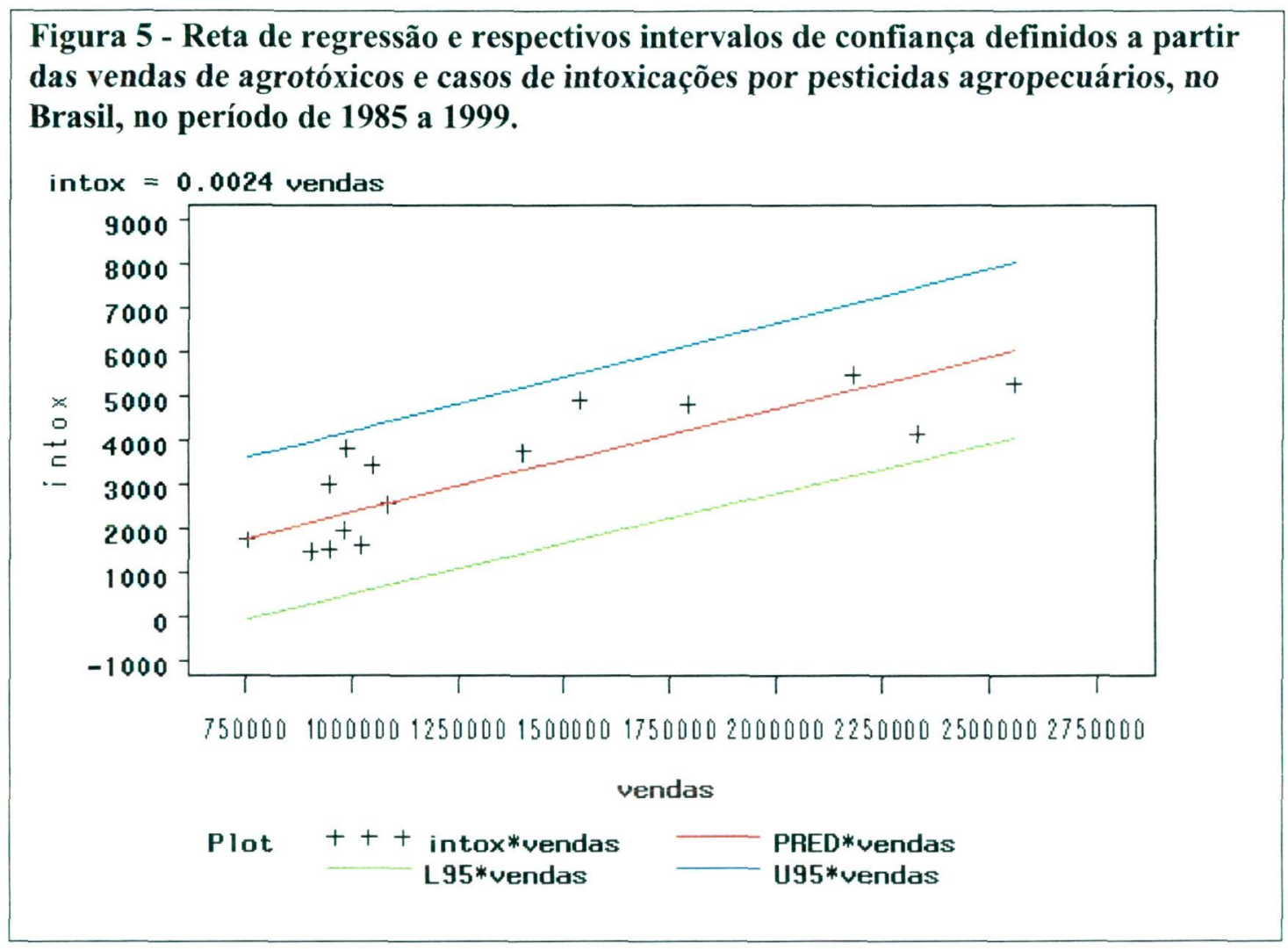

Fontes: Vendas - Futino e Silveira ${ }^{25}$; ANDEF $^{6}$; SINDAG $^{69}$.

Intoxicações - Bortoleto e col. ${ }^{8}$; SINITOX ${ }^{70,71,72,73,74,75,76}$

Esta equação permite estimar que a cada um bilhão de dólares vendido poderiam ser registrados pelo SINITOX cerca de 2360 casos de intoxicação, variando de 2042 a 2678 (IC 95\%). Por exemplo: o valor de vendas de agrotóxicos no Brasil em 2000 foi, segundo o SINDAG ${ }^{*}$, de US\$2,502,131,000.00 ; espera-se, então, que tenham sido registrados pelo SINITOX cerca de 5.905 casos de intoxicação, podendo variar de 5110 a 6700 casos, com 95\% de confiança. line]. Disponível em <URL: http://www.sindag.com.br/html/estat_dezembro.html>. [2001 jul 17]. 


\section{Objetivo específico $\mathbf{n}^{\circ} 2$}

As Tabelas 7 a 12 apresentam os resultados obtidos na avaliação estimativa do impacto da reclassificação toxicológica dos produtos comerciais que estavam registrados em 1990, pela modificação nas faixas de classificação determinada pela regulamentação da "Lei dos Agrotóxicos".

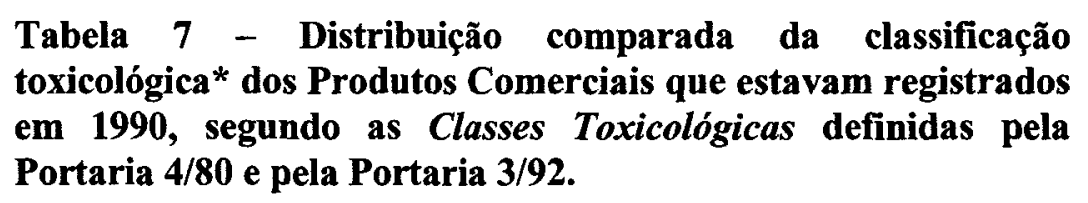

\begin{tabular}{ccccc}
\multirow{2}{*}{$\begin{array}{c}\text { CLASSE } \\
\text { TOXICOLÓGICA }\end{array}$} & \multicolumn{2}{c}{ Portaria } & $\mathbf{4 / 8 0} * *$ & \multicolumn{2}{c}{ Portaria $3 / \mathbf{9 2} * * *$} \\
\cline { 2 - 5 } & $\mathbf{N}^{\mathbf{0}}$ & $\%$ & $\mathbf{N}^{\mathbf{0}}$ & $\%$ \\
\hline I & 41 & 8,3 & 3 & 0,6 \\
II & 111 & 22,4 & 36 & 7,3 \\
III & 141 & 28,5 & 113 & 22,8 \\
IV & 202 & 40,8 & 343 & 69,3 \\
\hline TOTAL & 495 & 100,0 & 495 & 100,0
\end{tabular}

\footnotetext{
* As Classes Toxicológicas dos Produtos Comerciais foram determinadas a partir da $\mathrm{DL}_{50}$ dos mesmos, calculada por metodologia da $\mathrm{OMS}^{\mathbf{8 1}}$.

** Classes Toxicológicas P.4/80: I - altamente tóxico; II - medianamente tóxico; III - pouco tóxico; IV - praticamente não tóxico

*** Classes Toxicológicas P. 3/92: I - extremamente tóxico;

II - altamente tóxico; III - medianamente tóxico; IV - pouco tóxico

Fontes: Portaria DISAD $n^{\circ} 4 / 80^{53}$ e Portaria SNVS $n^{\circ} 3 / 92^{54}$
}

A comparação das distribuições da classificação toxicológica dos produtos comerciais (Tabela 7), para os quais foi possível determinar a Classe Toxicológica anterior e posterior à lei, mostrou, pelo teste de Qui-Quadrado de Tendência em Dados Ordenáveis $^{66}$, que elas são significativamente diferentes $(Z=-10,5166$ e $\mathrm{p}<0,0001)$. 
Tabela 8 - Distribuição da classificação toxicológica* dos Produtos Comerciais que estavam registrados em 1990, segundo a concordância entre as Classes Toxicológicas definidas pela Portaria 4/80 e pela Portaria 3/92.

\begin{tabular}{cccccc}
\hline & \multicolumn{5}{c}{ Portaria 4/80** } \\
\cline { 2 - 6 } $\begin{array}{c}\text { Portaria } \\
\mathbf{3 / 9 2 * * *}\end{array}$ & I & II & III & IV & Total \\
\hline I & 3 & 0 & 0 & 0 & 3 \\
II & 36 & 0 & 0 & 0 & 36 \\
III & 2 & 111 & 0 & 0 & 113 \\
IV & 0 & 0 & 141 & 202 & 343 \\
\hline Total & 41 & 111 & 141 & 202 & 495 \\
\hline
\end{tabular}

* As Classes Toxicológicas dos Produtos Comerciais foram determinadas a partir da $\mathrm{DL}_{50}$ dos mesmos, calculada por metodologia da $\mathrm{OMS}^{81}$.

** Classes Toxicológicas P. 4/80: I - altamente tóxico; II - medianamente tóxico; III - pouco tóxico;

IV - praticamente não tóxico

*** Classes Toxicológicas P. 3/92: I - extremamente tóxico; II - altamente tóxico;

III - medianamente tóxico; IV - pouco tóxico

Fontes: Portaria DISAD n ${ }^{\circ} 4 / 80^{53}$ e Portaria SNVS n ${ }^{\circ} 3 / 92^{54}$

Como pode ser observado na Tabela 8 , dos 41 produtos que poderiam estar classificados antes da lei na Classe Toxicológica I, apenas 3 se manteriam na mesma classe, 36 passariam para a Classe II e 2 passariam para a Classe III. No caso dos produtos que anteriormente poderiam estar classificados na Classe II e Classe III, todos seriam reclassificados, passando respectivamente para a Classe III (111 produtos) e Classe IV (141 produtos). Ou seja, dos 495 produtos comerciais para os quais foi possível determinar a Classe Toxicológica anterior e posterior à lei, 58,6\% poderiam ter sofrido reclassificação para Classes Toxicológicas consideradas de menor periculosidade.

Ainda pelos dados da Tabela 8, foi identificada uma baixa concordância estatística entre a classificação anterior e a posterior à lei pelo Coeficiente de $K_{\text {Kappa }}{ }^{14,40}(\mathrm{Kappa}=0,0780$; I.C. $95 \%$ [0,0427 a 0,1132]; p=0,0042).

Dos 495 produtos comerciais analisados, 311 são formulações líquidas e 184 sólidas. Como os intervalos que definem as faixas das Classes Toxicológicas são diferentes entre formulações líquidas e sólidas, o impacto da reclassificação também foi estimado considerando separadamente os dados desses tipos de formulações. 
A Tabela 9 e a Tabela 10 apresentam os dados parciais referentes às formulações líquidas.

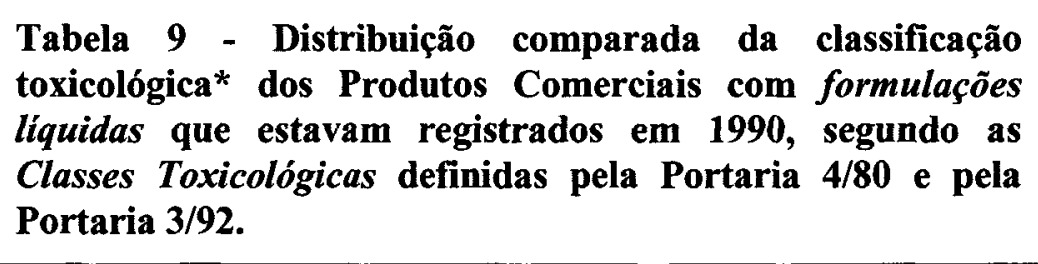

\begin{tabular}{ccccc}
\hline \multirow{2}{*}{$\begin{array}{c}\text { CLASSE } \\
\text { TOXICOLÓGICA }\end{array}$} & \multicolumn{2}{c}{ Portaria } & $\mathbf{4} / \mathbf{8 0 * *}$ & \multicolumn{2}{c}{ Portaria } & $\mathbf{3} / \mathbf{9 2}$ \\
\cline { 2 - 5 } & $\mathbf{N}^{\mathbf{0}}$ & $\mathbf{\%}$ & $\mathbf{N}^{\mathbf{0}}$ & $\mathbf{\%}$ \\
\hline I & 33 & 10,6 & 2 & 0,6 \\
II & 98 & 31,5 & 31 & 10,0 \\
III & 104 & 33,4 & 98 & 31,5 \\
IV & 76 & 24,4 & 180 & 57,9 \\
\hline TOTAL & 311 & 100,0 & 311 & 100,0
\end{tabular}

\footnotetext{
* As Classes Toxicológicas dos Produtos Comerciais foram determinadas a partir da $\mathrm{DL}_{50}$ dos mesmos, calculada por metodologia da $\mathrm{OMS}^{81}$.

* Classes Toxicológicas P. 4/80: I - altamente tóxico;

II - medianamente tóxico; III - pouco tóxico; IV - praticamente não tóxico

*** Classes Toxicológicas P. 3/92: I - extremamente tóxico;

II - altamente tóxico; III - medianamente tóxico; IV - pouco tóxico

Fontes: Portaria DISAD $n^{\circ} 4 / 80^{53}$ e Portaria SNVS n $3 / 92^{54}$
}

Pelo teste de Qui-Quadrado de Tendência em Dados Ordenáveis ${ }^{66}$, a comparação das distribuições da classificação toxicológica dos produtos comerciais com formulações líquidas, para os quais foi possível determinar a Classe Toxicológica anterior e posterior à lei (Tabela 9), mostrou que elas são significativamente diferentes $(Z=-10,2199$ e $p<0,0001)$. 
Tabela 10 - Distribuição da classificação toxicológica* dos Produtos Comerciais com formulações líquidas que estavam registrados em 1990, segundo a concordância entre as Classes Toxicológicas definidas pela Portaria 4/80 e pela Portaria 3/92.

\begin{tabular}{cccccc} 
Portaria & \multicolumn{5}{c}{ Portaria 4/80** } \\
\cline { 2 - 6 } $\mathbf{3 / 9 2 * * *}^{*}$ & I & II & III & IV & Total \\
\hline I & 2 & 0 & 0 & 0 & 2 \\
II & 31 & 0 & 0 & 0 & 31 \\
III & 0 & 98 & 0 & 0 & 98 \\
IV & 0 & 0 & 104 & 76 & 180 \\
\hline Total & 33 & 98 & 104 & 76 & 311 \\
\hline
\end{tabular}

* As Classes Toxicológicas dos Produtos Comerciais foram determinadas a partir da $\mathrm{DL}_{50}$ dos mesmos, calculada por metodologia da $\mathrm{OMS}^{81}$.

** Classes Toxicológicas P. 4/80: I - altamente tóxico; II - medianamente tóxico; III - pouco tóxico; IV - praticamente não tóxico

*** Classes Toxicológicas P. 3/92: I - extremamente tóxico; II - altamente tóxico;

III - medianamente tóxico;
Fontes: Portaria DISAD n ${ }^{\circ} 4 / 80^{53}$ e Portaria SNVS $n^{\circ} 3 / 92^{54}$

Como pode ser observado na Tabela 10, dos 33 produtos que poderiam estar classificados antes da lei na Classe I, apenas 2 se manteriam na mesma classe e 31 passariam para a Classe II. No caso dos produtos que anteriormente poderiam estar classificados na Classe II e Classe III, todos seriam reclassificados, passando respectivamente para a Classe III (98 produtos) e Classe IV (104 produtos). Ou seja, dos 311 produtos comerciais com formulações líquidas para os quais foi possível determinar a Classe Toxicológica anterior e posterior à lei, 74,9\% poderiam ter sofrido reclassificação para Classes Toxicológicas consideradas de menor periculosidade.

Ainda pelos dados da Tabela 10, foi identificado que não há concordância estatística entre a classificação anterior e a posterior à lei pelo Coeficiente de $\operatorname{Kappa}^{14}$ (Kappa=-0,0390; I.C. 95\% [-0,0853 a 0,0073]; p=0,2135). 
A Tabela 11 e a Tabela 12 apresentam os dados parciais referentes às formulações sólidas.

Tabela 11 - Distribuição comparada da classificação toxicológica* dos Produtos Comerciais com formulaçôes sólidas que estavam registrados em 1990, segundo as Classes Toxicológicas definidas pela Portaria $4 / 80$ e pela Portaria $3 / 92$.

\begin{tabular}{|c|c|c|c|c|}
\hline \multirow{2}{*}{$\begin{array}{c}\text { CLASSE } \\
\text { TOXICOLÓGICA }\end{array}$} & \multicolumn{2}{|c|}{ Portaria $4 / 80^{* * *}$} & \multicolumn{2}{|c|}{ Portaria $3 / 92^{* * *}$} \\
\hline & $\mathbf{N}^{0}$ & $\%$ & $\mathbf{N}^{\mathbf{0}}$ & $\%$ \\
\hline $\mathbf{I}$ & 8 & 4,3 & 1 & 0,5 \\
\hline II & 13 & 7,1 & 5 & 2,7 \\
\hline III & 37 & 20,1 & 15 & 8,2 \\
\hline IV & 126 & 68,5 & 163 & 88,6 \\
\hline TOTAL & 184 & 100,0 & 184 & 100,0 \\
\hline \multicolumn{5}{|c|}{$\begin{array}{l}\text { * As Classes Toxicológicas dos Produtos Comerciais foram } \\
\text { determinadas a partir da } \mathrm{DL}_{50} \text { dos mesmos, calculada por metodologia } \\
\text { da OMS }{ }^{81} \text {. } \\
\text { ** Classes Toxicológicas } \mathrm{P} .4 / 80: \mathrm{I} \text { - altamente tóxico; } \\
\text { II - medianamente tóxico; III - pouco tóxico; IV - praticamente não } \\
\text { tóxico } \\
* * * \text { Classes Toxicológicas P. } 3 / 92: \text { I - extremamente tóxico; } \\
\text { II - altamente tóxico; III - medianamente tóxico; IV - pouco tóxico } \\
\text { Fontes: Portaria DISAD n }{ }^{\circ} 4 / 80^{53} \text { e Portaria SNVS } n^{\circ} 3 / 92^{54}\end{array}$} \\
\hline
\end{tabular}

Pelo teste de Qui-Quadrado de Tendência em Dados Ordenáveis ${ }^{66}$, a comparação das distribuições da classificação toxicológica dos produtos comerciais com formulações sólidas, para os quais foi possível determinar a Classe Toxicológica anterior e posterior à lei (Tabela 11), mostrou que elas são significativamente diferentes $(Z=-4,5376$ e $\mathrm{p}<0,0001)$. 
Tabela 12 - Distribuição da classificação toxicológica* dos Produtos Comerciais com formulações sólidas que estavam registrados em 1990, segundo a concordância entre as Classes Toxicológicas definidas pela Portaria 4/80 e pela Portaria 3/92.

\begin{tabular}{|c|c|c|c|c|c|}
\hline \multirow{2}{*}{$\begin{array}{l}\text { Portaria } \\
3 / 92 * * *\end{array}$} & \multicolumn{5}{|c|}{ Portaria $4 / 80 * *$} \\
\hline & I & II & III & IV & Total \\
\hline I & 1 & 0 & 0 & 0 & 1 \\
\hline II & 5 & 0 & 0 & 0 & 5 \\
\hline III & 2 & 13 & 0 & 0 & 15 \\
\hline IV & 0 & 0 & 37 & 126 & 163 \\
\hline Total & 8 & 13 & 37 & 126 & 184 \\
\hline $\begin{array}{l}\text { * As Classes } 1 \\
\text { mesmos, calcu } \\
{ }^{* *} \text { Classes To } \\
\text { *** Classes T } \\
\text { Fontes: Port }\end{array}$ & $\begin{array}{l}\text { metc } \\
\text { as } \mathrm{P} \text {. } \\
\text { cas } 1 \\
\mathrm{AD} \text {. }\end{array}$ & $\begin{array}{l}\text { s Co } \\
\text { oMS } \\
\text { amer } \\
\text { atica } \\
\text { extre } \\
\text { med } \\
\text { ortari }\end{array}$ & $\begin{array}{l}\text { Im de } \\
\text { I-me } \\
\text { Sxico } \\
\text { xico; } \\
\text { xico; } \\
3 / 92^{5}\end{array}$ & $\begin{array}{l}\text { a part } \\
\text { e tóxic } \\
\text { nte tó } \\
\text { o tóxi }\end{array}$ & $\begin{array}{l}\text { dos } \\
\text { uco tóxicc }\end{array}$ \\
\hline
\end{tabular}

Como pode ser observado na Tabela 12, dos 8 produtos que poderiam estar classificados antes da lei na Classe I, apenas 1 se manteria na mesma classe, 5 passariam para a Classe II e 2 passariam para a Classe III. No caso dos produtos que anteriormente poderiam estar classificados na Classe II e Classe III, todos seriam reclassificados, passando respectivamente para a Classe III (13 produtos) e Classe IV (37 produtos). Ou seja, dos 184 produtos comerciais com formulações sólidas para os quais foi possível determinar a Classe Toxicológica anterior e posterior à lei, $31,0 \%$ poderiam ter sofrido reclassificação para Classes Toxicológicas consideradas de menor periculosidade.

Ainda pelos dados da Tabela 12, foi identificada uma baixa concordância estatística entre a classificação anterior e a posterior à lei pelo Coeficiente de $K_{\text {Kappa }}{ }^{14,40}$ (Kappa=0,1735; I.C. 95\% [0,1049 a 0,2421]; p=0,0003). 


\section{Objetivo específico $n^{0} 3$}

\section{Total dos ingredientes ativos}

A Tabela 13 apresenta a distribuição geral, segundo a Classe de Uso, dos ingredientes ativos que foram identificados como estando registrados nos anos de 1990 e 2000 e das novas substâncias registradas após a "Lei dos Agrotóxicos".

Tabela 13 - Distribuição dos Ingredientes Ativos que estavam registrados em 1990, dos que foram registrados após a "Lei dos Agrotóxicos" (Lei 7802/89) e dos que estavam registrados em 2000, segundo a Classe de Uso e o aumento relativo de registros ocorrido no período.

\begin{tabular}{|c|c|c|c|c|c|c|c|}
\hline \multirow{2}{*}{$\begin{array}{c}\text { CLASSE } \\
\text { DE USO * }\end{array}$} & \multicolumn{2}{|c|}{1990} & \multicolumn{2}{|c|}{ Novos ** } & \multicolumn{2}{|c|}{2000} & \multirow{2}{*}{$\begin{array}{c}\text { Aumento } \\
\text { relativo } \\
\text { no período } \\
\%\end{array}$} \\
\hline & $\mathbf{N}^{0}$ & $\%$ & $\mathbf{N}^{0}$ & $\%$ & $\mathbf{N}^{\mathbf{o}}$ & $\%$ & \\
\hline Inseticidas & 87 & 37,5 & 44 & 32,6 & 128 & 35,4 & 47,1 \\
\hline Fungicidas & 54 & 23,3 & 34 & 25,2 & 87 & 24,0 & 61,1 \\
\hline Herbicidas & 66 & 28,4 & 39 & 28,9 & 105 & 29,0 & 59,1 \\
\hline Outros & 25 & 10,8 & 18 & 13,3 & 42 & 11,6 & 68,0 \\
\hline TOTAL & 232 & 100,0 & 135 & 100,0 & 362 & 100,0 & 56,0 \\
\hline \multicolumn{8}{|c|}{$\begin{array}{l}\text { * Classe de Uso - Inseticidas: inseticidas, acaricidas, formicidas, fumigantes, moluscicidas, nematicidas } \\
\text { - Fungicidas: fungicidas, antibióticos, bactericidas; } \\
\text { - Herbicidas: herbicidas, dessecantes; } \\
\text { - Outros: adjuvantes, antibrotantes, espalhantes adesivos, estimulantes, feromônios, } \\
\text { reguladores de crescimento, surfactantes agrícolas. } \\
\text { ** Novos: Ingredientes Ativos registrados após a "Lei dos Agrotóxicos"; }\end{array}$} \\
\hline
\end{tabular}

Os dados indicam que houve um aumento relativo de $56,0 \%$ no número de ingredientes ativos registrados no período. $O$ maior número de registros de ingredientes ativos no período se deu na classe dos inseticidas, seguida, em ordem decrescente, pelas classes dos herbicidas, fungicidas e "outros". Em termos de 
crescimento relativo, porém, se deu exatamente o inverso: o maior crescimento foi na classe "outros", seguida, em ordem decrescente, pela de fungicidas, herbicidas e inseticidas. No entanto, todas as variações são pequenas, pois aplicando o teste do Qui-Quadrado de Tendência em Dados Ordenáveis ${ }^{66}$, não foi constatada diferença estatisticamente significativa nas distribuições dos ingredientes ativos segundo a Classe de Uso, entre os anos de 1990 e 2000 ( $\mathrm{Z}=-0,4983$ e $\mathrm{p}<0,6183$ ). Tampouco há diferença estatisticamente significativa quando comparadas as distribuições das Classes de Uso entre as substâncias que estavam registradas antes e as que foram registradas depois da "Lei dos Agrotóxicos" $(\mathrm{Z}=-0,9279$ e $\mathrm{p}<0,3534)$.

A Tabela 14 mostra o movimento de entrada, saída e alterações nas classificações de ingredientes ativos, entre os anos de 1990 e 2000.

Tabela 14 - Ingredientes Ativos que estavam registrados em 1990 e 2000, segundo a classe de periculosidade da OMS e a eliminação, reclassificação ou entrada de novos registros no período.

\begin{tabular}{|c|c|c|c|c|c|c|c|}
\hline \multirow{2}{*}{$\begin{array}{c}\text { CLASSE DE } \\
\text { PERICULOSIDADE } \\
\left(^{*}\right)\end{array}$} & \multirow[t]{2}{*}{1990} & \multirow{2}{*}{$\begin{array}{l}\text { Não mais } \\
\text { registrados }\end{array}$} & \multicolumn{2}{|c|}{$\begin{array}{c}\text { Reclassificação } \\
\text { pela OMS }\end{array}$} & \multirow{2}{*}{$\begin{array}{c}\text { Permaneceram } \\
\text { registrados } \\
\text { após } 1990 \\
\text { (classificação } \\
\text { atualizada) }\end{array}$} & \multirow[t]{2}{*}{ Novos } & \multirow[t]{2}{*}{2000} \\
\hline & & & Saídas & Entradas & & & \\
\hline Ia & 12 & - & 3 & 1 & 10 & 1 & 11 \\
\hline Ib & 21 & 1 & 3 & 1 & 18 & 2 & 20 \\
\hline II & 47 & - & 2 & 5 & 50 & 17 & 67 \\
\hline III & 37 & 1 & 3 & 5 & 38 & 21 & 59 \\
\hline $\mathbf{U}$ & 68 & 1 & 4 & 4 & 67 & 37 & 104 \\
\hline $\bar{F}$ & 3 & - & - & - & 3 & - & 3 \\
\hline $\mathbf{0}$ & 1 & 1 & - & 9 & 9 & 1 & 10 \\
\hline $\mathbf{S} / \mathbf{I}$ & 43 & 1 & 10 & - & 32 & 56 & 88 \\
\hline TOTAL & 232 & 5 & 25 & 25 & 227 & 135 & 362 \\
\hline Fontes: $\mathrm{OMS}^{81,82}, \mathrm{Mi}$ & $\begin{array}{l}\text { ade: Ia } \\
\text { II } \\
\text { U- } \\
\text { F- } \\
\text { stério d. }\end{array}$ & $\begin{array}{l}\text { extremamente } \\
\text { moderadame } \\
\text { improvável d } \\
\text { fumigante; } \\
\text { Saúde }^{\mathbf{5}} \text {, Agrc }\end{array}$ & $\begin{array}{l}\text { erigoso; } \\
\text { te perigos } \\
\text { apresentas } \\
\text { - obsolett } \\
\text { t/98 }\end{array}$ & $\begin{array}{r}\mathrm{Ib}-\text { alta } \\
\mathrm{III}-\mathrm{le} \\
\text { rigo agudd } \\
\mathrm{S} / \mathrm{I}-\mathrm{s}\end{array}$ & $\begin{array}{l}\text { nente perigoso; } \\
\text { emente perigoso; } \\
\text { sob uso normal; } \\
\text { m informação }\end{array}$ & & \\
\hline
\end{tabular}

Fontes: $\mathrm{OMS}^{81,82}$, Ministério da Saúde ${ }^{50}$, Agrofit $/ 98^{48}$, Agrotis ${ }^{1}$ 
As alterações entre os anos de referência, em cada classe de periculosidade, ocorreram por entrada de novas substâncias, por reclassificação de substâncias pela OMS e por substâncias que deixaram de ser registradas. No total, 5 substâncias deixaram de ser registradas, 25 foram reclassificadas pela OMS e 135 novos ingredientes ativos foram registrados no período.

Do total das substâncias que se encontravam registradas em 1990 e em 2000 , 18,5\% e 24,3\%, respectivamente, não constavam da classificação de periculosidade da OMS. A Tabela 15 apresenta a distribuição dos ingredientes ativos que estavam classificados pela OMS, segundo a classe de periculosidade, para os anos de $1990 \mathrm{e}$ 2000 e das novas substâncias registradas após a Lei.

Tabela 15 - Distribuição dos Ingredientes Ativos classificados pela OMS que estavam registrados em 1990, dos que foram registrados após a "Lei dos Agrotóxicos" (Lei 7802/89) e dos que estavam registrados em 2000, segundo a Classe de Periculosidade definida pela Organização Mundial da Saúde - OMS.

\begin{tabular}{|c|c|c|c|c|c|c|}
\hline \multirow{2}{*}{$\begin{array}{c}\text { CLASSE DE } \\
\text { PERICULOSIDADE* }\end{array}$} & \multicolumn{2}{|c|}{$1990 * *$} & \multicolumn{2}{|c|}{ NOVOS*** } & \multicolumn{2}{|c|}{2000} \\
\hline & $\mathbf{N}^{\circ}$ & $\%$ & $\mathbf{N}^{\mathbf{0}}$ & $\%$ & $\mathbf{N}^{0}$ & $\%$ \\
\hline Ia & 10 & 5,5 & 1 & 1,3 & 11 & 4,2 \\
\hline Ib & 18 & 9,8 & 2 & 2,6 & 20 & 7,7 \\
\hline II & 50 & 27,3 & 17 & 21,8 & 67 & 25,7 \\
\hline $\mathbf{I I I}+\mathbf{U}$ & 105 & 57,4 & 58 & 74,3 & 163 & 62,4 \\
\hline TOTAL & 183 & 100,0 & 78 & 100,0 & 261 & 100,0 \\
\hline \multicolumn{7}{|c|}{$\begin{array}{l}\text { * Classes de periculosidade: Ia - extremamente perigoso; Ib - altamente perigoso; } \\
\text { II - moderadamente perigoso; III - levemente perigoso; } \\
\text { U - improvável de apresentar perigo agudo sob uso normal; } \\
\text { ** Substâncias registradas antes da "Lei dos Agrotóxicos", com classificação atualizada pelo } \\
\text { guia de classificação da OMS } 1988 / 1999^{82} \\
*_{* * *} \text { Novos: Ingredientes Ativos registrados após a "Lei dos Agrotóxicos" }\end{array}$} \\
\hline
\end{tabular}

Fontes: OMS ${ }^{81,82}$, Ministério da Saúde ${ }^{50},{\text { Agrofit } / 98^{48}}$ Agrotis $^{1}$ 
Aplicando o teste do Qui-Quadrado de Tendência em Dados Ordenáveis ${ }^{66}$, foi constatada diferença estatisticamente significativa nas distribuições dos ingredientes ativos, segundo a classe de periculosidade, entre o conjunto de substâncias que estavam registradas antes da Lei, em 1990 e as novas substâncias registradas no período em estudo $(Z=-2,9810$ e $p<0,0029)$, mas não foi constatada diferença quando comparados os totais de substâncias que estavam registradas nos anos de 1990 e $2000(Z=-1,2092$ e $p<0,2266)$.

A seguir são apresentados os resultados por Classe de Uso: inseticidas, fungicidas, herbicidas e "outros".

\section{Inseticidas}

Os inseticidas apresentaram o menor crescimento relativo no período $(47,1 \%)$, em termos de número de ingredientes ativos registrados, entre as diferentes Classes de Uso (Tabela 13).

Como mostra a Tabela 16, as alterações entre os anos de referência, em cada classe de periculosidade, ocorreram por entrada de novas substâncias, por reclassificação de substâncias pela OMS e por substâncias que deixaram de ser registradas. 
Tabela 16 - Ingredientes Ativos de inseticidas* que estavam registrados em 1990 e 2000, segundo a classe de periculosidade da Organização Mundial da Saúde - OMS e a eliminação, reclassificação ou entrada de novos registros no período.

\begin{tabular}{|c|c|c|c|c|c|c|c|}
\hline \multirow{2}{*}{$\begin{array}{c}\text { CLASSE DE } \\
\text { PERICULOSIDADE** }\end{array}$} & \multirow[t]{2}{*}{1990} & \multirow{2}{*}{$\begin{array}{l}\text { Não mais } \\
\text { registrados }\end{array}$} & \multicolumn{2}{|c|}{$\begin{array}{c}\text { Reclassificação } \\
\text { pela OMS }\end{array}$} & \multirow{2}{*}{$\begin{array}{l}\text { Permaneceram } \\
\text { registrados } \\
\text { após } 1990 \\
\text { (classificação } \\
\text { atualizada) }\end{array}$} & \multirow[t]{2}{*}{ Novos } & \multirow[t]{2}{*}{2000} \\
\hline & & & Saídas & Entradas & & & \\
\hline Ia & 11 & - & 2 & - & 9 & 1 & 10 \\
\hline Ib & 20 & 1 & 3 & 1 & 17 & 2 & 19 \\
\hline II & 28 & - & 2 & 3 & 29 & 12 & 41 \\
\hline III & 10 & 1 & 2 & - & 7 & 5 & 12 \\
\hline $\mathbf{U}$ & 9 & - & - & - & 9 & 10 & 19 \\
\hline $\mathbf{F}$ & 3 & - & - & - & 3 & - & 3 \\
\hline $\mathbf{O}$ & 1 & 1 & - & 6 & 6 & - & 6 \\
\hline S/I & 5 & - & 1 & - & 4 & 14 & 18 \\
\hline TOTAL & 87 & 3 & 10 & 10 & 84 & 44 & 128 \\
\hline
\end{tabular}

* Inseticidas: inseticidas, acaricidas, formicidas, fumigantes, moluscicidas, nematicidas;

** Classes de periculosidade: Ia - extremamente perigoso; Ib - altamente perigoso; II - moderadamente perigoso; III - levemente perigoso; $\mathrm{U}$ - improvável de apresentar perigo agudo sob uso normal; $\mathrm{F}$ - fumigante; $\mathrm{O}$ - obsoleto; $\mathrm{S} / \mathrm{I}$ - sem informação Fontes: $\mathrm{OMS}^{81,82}$, Ministério da Saúde ${ }^{50}$, Agrofit $/ 98^{48}$, Agrotis ${ }^{1}$

Do total dos ingredientes ativos de inseticidas que estavam registrados nos anos de 1990 e $2000,5,7 \%$ e $14,1 \%$, respectivamente, não constavam da classificação da OMS. Para aqueles que constavam (Tabela 17), aplicando o teste do Qui-Quadrado de Tendência em Dados Ordenáveis ${ }^{66}$, foi constatada diferença estatisticamente significativa nas distribuições dos ingredientes ativos, segundo a classe de periculosidade, entre o conjunto de substâncias que estavam registradas em 1990 e as novas substâncias registradas no período em estudo $(Z=-3,0966$ e $\mathrm{p}<0,0020$ ), mas não foi constatada diferença quando comparados os totais de substâncias que estavam registradas nos anos de 1990 e $2000 \quad(Z=-1,2824$ e $\mathrm{p}<0,1997)$. 
Tabela 17 - Distribuição dos Ingredientes Ativos de inseticidas* que foram registrados antes da "Lei dos Agrotóxicos" (Lei 7802/89) e estavam registrados em 1990, dos que foram registrados após a Lei e dos que estavam registrados em 2000, segundo a Classe de Periculosidade definida pela Organização Mundial da Saúde - OMS.

\begin{tabular}{|c|c|c|c|c|c|c|}
\hline \multirow{2}{*}{$\begin{array}{c}\text { CLASSE DE } \\
\text { PERICULOSIDADE** }\end{array}$} & \multicolumn{2}{|c|}{$1990 * * *$} & \multicolumn{2}{|c|}{ NOVOS**** } & \multicolumn{2}{|c|}{2000} \\
\hline & $\mathbf{N}^{\mathbf{0}}$ & $\%$ & $\mathbf{N}^{0}$ & $\%$ & $\mathbf{N}^{0}$ & $\%$ \\
\hline Ia & 9 & 12,7 & 1 & 3,3 & 10 & 9,9 \\
\hline Ib & 17 & 23,9 & 2 & 6,7 & 19 & 18,8 \\
\hline II & 29 & 40,8 & 12 & 40,0 & 41 & 40,6 \\
\hline $\mathbf{I I I}+\mathbf{U}$ & 16 & 22,6 & 15 & 50,0 & 31 & 30,7 \\
\hline TOTAL & 71 & 100,0 & 30 & 100,0 & 101 & 100,0 \\
\hline
\end{tabular}

* Inseticidas: inseticidas, acaricidas, formicidas, fumigantes, moluscicidas, nematicidas

** Classes de periculosidade: Ia - extremamente perigoso; Ib - altamente perigoso;

II - moderadamente perigoso; III - levemente perigoso; U - improvável de apresentar perigo agudo sob uso normal;

*** substâncias com classificação atualizada pelo guia de classificação da OMS $1988 / 1999^{82}$

**** Novos: Ingredientes Ativos registrados após a "Lei dos Agrotóxicos"

Fontes: $\mathrm{OMS}^{81,82}$, Ministério da Saúde ${ }^{50},{\text { Agrofit } / 98^{48}}^{4}$, Agrotis ${ }^{1}$

Podemos destacar que somente entre os inseticidas foi possível identificar registros de novas substâncias classificadas pela OMS nas Classes Ia e Ib, de maior periculosidade.

\section{Fungicidas}

Os fungicidas apresentaram um crescimento relativo no período de $61,1 \%$, em termos de número de ingredientes ativos registrados, entre as diferentes Classes de Uso (Tabela 13).

Como mostra a Tabela 18, as alterações entre os anos de referência, em cada classe de periculosidade, ocorreram por entrada de novas substâncias, por 
reclassificação de substâncias pela OMS e por substâncias que deixaram de ser registradas.

Tabela 18 - Ingredientes Ativos de fungicidas* que estavam registrados em 1990 e 2000 , segundo a classe de periculosidade da OMS e a eliminação, reclassificação ou entrada de novos registros no período.

\begin{tabular}{|c|c|c|c|c|c|c|c|}
\hline \multirow{2}{*}{$\begin{array}{c}\text { CLASSE DE } \\
\text { PERICULOSIDADE** }\end{array}$} & \multirow[t]{2}{*}{1990} & \multirow{2}{*}{$\begin{array}{l}\text { Não mais } \\
\text { registrados }\end{array}$} & \multicolumn{2}{|c|}{$\begin{array}{c}\text { Reclassificação } \\
\text { pela OMS }\end{array}$} & \multirow{2}{*}{$\begin{array}{c}\text { Permaneceram } \\
\text { registrados } \\
\text { após } 1990 \\
\text { (classificação } \\
\text { atualizada) }\end{array}$} & \multirow[t]{2}{*}{ Novos } & \multirow[t]{2}{*}{2000} \\
\hline & & & Saídas & Entradas & & & \\
\hline $\mathbf{I a}$ & - & - & - & - & - & - & - \\
\hline Ib & 1 & - & - & - & 1 & - & 1 \\
\hline II & 7 & - & - & 1 & 8 & 4 & 12 \\
\hline III & 11 & - & - & 2 & 13 & 9 & 22 \\
\hline $\mathbf{U}$ & 24 & 1 & 2 & 2 & 23 & 11 & 34 \\
\hline $\mathbf{F}$ & - & - & - & - & - & - & - \\
\hline $\mathbf{O}$ & - & - & - & 2 & 2 & - & 2 \\
\hline $\mathbf{S} / \mathbf{I}$ & 11 & - & 5 & - & 6 & 10 & 16 \\
\hline TOTAL & 54 & 1 & 7 & 7 & 53 & 34 & 87 \\
\hline
\end{tabular}

* Fungicidas: fungicidas, antibióticos, bactericidas;

** Classes de periculosidade: Ia - extremamente perigoso; $\quad \mathrm{Ib}$ - altamente perigoso;

II - moderadamente perigoso; III - levemente perigoso;

U - improvável de apresentar perigo agudo sob uso normal;

Fontes: $\mathrm{OMS}^{81,82}$, Ministério da Saúde ${ }^{50}$, Agrofit $/ 98^{48}$, Agrotis $^{1}$

S/I - sem informação

Do total dos ingredientes ativos de fungicidas que estavam registrados nos anos de 1990 e $2000,20,4 \%$ e $18,4 \%$, respectivamente, não constavam da classificação da OMS. Para aqueles que constavam (Tabela 19), a aplicação do QuiQuadrado de Tendência em Dados Ordenáveis ${ }^{66}$ não indicou diferença significativa na distribuição dos mesmos segundo as classes de periculosidade definidas pela OMS , seja na comparação entre o conjunto de substâncias que estava registrado em 1990 e o conjunto de novas substâncias $(Z=-0,5033$ e $p<0,6148)$, seja na comparação entre os conjuntos de substâncias que estavam registrados em $1990 \mathrm{e}$ $2000(\mathrm{Z}=-0,2248$ e $\mathrm{p}<0,8222)$. 
Tabela 19 - Distribuição dos Ingredientes Ativos de fungicidas* que foram registrados antes da "Lei dos Agrotóxicos" (Lei 7802/89) e estavam registrados em 1990, dos que foram registrados após a Lei e dos que estavam registrados em 2000, segundo a Classe de Periculosidade definida pela Organização Mundial da Saúde - OMS.

\begin{tabular}{|c|c|c|c|c|c|c|}
\hline \multirow{2}{*}{$\begin{array}{c}\text { CLASSE DE } \\
\text { PERICULOSIDADE** }\end{array}$} & \multicolumn{2}{|c|}{$1990 * * *$} & \multicolumn{2}{|c|}{ NOVOS $* * * *$} & \multicolumn{2}{|c|}{2000} \\
\hline & $\mathbf{N}^{0}$ & $\%$ & $\mathbf{N}^{\mathbf{0}}$ & $\%$ & $\mathbf{N}^{0}$ & $\%$ \\
\hline$\overline{I a}$ & - & - & - & - & - & - \\
\hline Ib & 1 & 2,2 & - & - & 1 & 1,4 \\
\hline II & 8 & 17,8 & 4 & 16,7 & 12 & 17,4 \\
\hline $\mathbf{I I I}+\mathbf{U}$ & 36 & 80,0 & 20 & 83,3 & 56 & 81,2 \\
\hline TOTAL & 45 & 100,0 & 24 & 100,0 & 69 & 100,0 \\
\hline
\end{tabular}

\footnotetext{
* Fungicidas: fungicidas, antibióticos, bactericidas

** Classes de periculosidade: Ia - extremamente perigoso; Ib - altamente perigoso;

II - moderadamente perigoso; III - levemente perigoso;

U - improvável de apresentar perigo agudo sob uso normal;

*** substâncias com classificação atualizada pelo guia de classificação da OMS $1988 / 1999^{82}$

**** Novos: Ingredientes Ativos registrados após a "Lei dos Agrotóxicos"
}

Fontes: $\mathrm{OMS}^{81,82}$, Ministério da Saúde ${ }^{50}$, Agrofit $/ 98^{48}{ }^{\text {, Agrotis }}{ }^{1}$

\section{$\underline{\text { Herbicidas }}$}

Os herbicidas apresentaram um crescimento relativo de $59,1 \%$ no período, em termos de número de ingredientes ativos registrados (Tabela 13).

Como mostra a Tabela 20, as alterações entre os anos de referência, em cada classe de periculosidade, ocorreram por entrada de novas substâncias e por reclassificação de substâncias registradas. 
Tabela 20 - Ingredientes Ativos de herbicidas* que estavam registrados em 1990 e 2000 , segundo a classe de periculosidade da OMS e a eliminação, reclassificação ou entrada de novos registros no período.

\begin{tabular}{|c|c|c|c|c|c|c|c|}
\hline \multirow{2}{*}{$\begin{array}{c}\text { CLASSE DE } \\
\text { PERICULOSIDADE** }\end{array}$} & \multirow[t]{2}{*}{1990} & \multirow{2}{*}{$\begin{array}{l}\text { Não mais } \\
\text { registrados }\end{array}$} & \multicolumn{2}{|c|}{$\begin{array}{c}\text { Reclassificação } \\
\text { pela OMS }\end{array}$} & \multirow{2}{*}{\begin{tabular}{|c|} 
Permaneceram \\
registrados \\
após 1990 \\
(classificação \\
atualizada)
\end{tabular}} & \multirow[t]{2}{*}{ Novos } & \multirow[t]{2}{*}{2000} \\
\hline & & & Saídas & Entradas & & & \\
\hline Ia & 1 & - & 1 & 1 & 1 & - & 1 \\
\hline Ib & - & - & - & - & - & - & - \\
\hline II & 12 & - & - & 1 & 13 & 1 & 14 \\
\hline III & 15 & - & 1 & 3 & 17 & 6 & 23 \\
\hline $\mathbf{U}$ & 32 & - & 2 & 2 & 32 & 14 & 46 \\
\hline $\mathbf{F}$ & - & - & - & - & - & - & - \\
\hline $\mathbf{0}$ & - & - & - & 1 & 1 & - & 1 \\
\hline $\mathbf{S} / \mathbf{I}$ & 6 & - & 4 & - & 2 & 18 & 20 \\
\hline TOTAL & 66 & - & 8 & 8 & 66 & 39 & 105 \\
\hline
\end{tabular}

* Herbicidas: herbicidas, dessecantes;

** Classes de periculosidade: Ia - extremamente perigoso; $\quad \mathrm{Ib}$ - altamente perigoso; II - moderadamente perigoso; III - levemente perigoso; U - improvável de apresentar perigo agudo sob uso normal; $\mathrm{F}$ - fumigante; $\mathrm{O}$ - obsoleto; $\mathrm{S} / \mathrm{I}$ - sem informação

Fontes: $\mathrm{OMS}^{81,82}$, Ministério da Saúde ${ }^{50}$, Agrofit $/ 98^{48}$, Agrotis ${ }^{1}$

Do total dos ingredientes ativos de herbicidas que estavam registrados nos anos de 1990 e 2000, 9,1\% e 19,0\%, respectivamente, não constavam da classificação da OMS. Para aqueles que constavam (Tabela 21), a aplicação do QuiQuadrado de Tendência em Dados Ordenáveis ${ }^{66}$ não indicou diferença significativa na distribuição dos mesmos segundo as classes de periculosidade definidas pela OMS, seja na comparação entre o conjunto de substâncias que estava registrado em 1990 e o conjunto de novas substâncias $(Z=-1,6971$ e $p<0,0897)$, seja na comparação entre os conjuntos de substâncias que estavam registrados em 1990 e $2000(Z=-0,6121$ e $p<0,5405)$. 
Tabela 21 - Distribuição dos Ingredientes Ativos de herbicidas* que foram registrados antes da "Lei dos Agrotóxicos" (Lei 7802/89) e estavam registrados em 1990, dos que foram registrados após a Lei e dos que estavam registrados em 2000, segundo a Classe de Periculosidade definida pela Organização Mundial da Saúde - OMS.

\begin{tabular}{c|cc|cc|cc}
\hline \multirow{2}{*}{$\begin{array}{c}\text { CLASSE DE } \\
\text { PERICULOSIDADE* }\end{array}$} & \multicolumn{2}{|c|}{$\mathbf{1 9 9 0 * *}^{*}$} & \multicolumn{2}{|c|}{ NOVOS*** } & \multicolumn{2}{|c}{$\mathbf{2 0 0 0}$} \\
\cline { 2 - 8 } & $\mathbf{N}^{\mathbf{o}}$ & $\mathbf{\%}$ & \multicolumn{2}{|c}{$\mathbf{N}^{\mathbf{0}}$} & $\mathbf{\%}$ & \multicolumn{2}{|c}{$\mathbf{N}^{\mathbf{0}}$} & $\%$ \\
\hline Ia & 1 & 1,6 & - & - & 1 & 1,2 \\
Ib & - & - & - & - & - & - \\
II & 13 & 20,6 & 1 & 4,8 & 14 & 16,7 \\
III + U & 49 & 77,8 & 20 & 95,2 & 69 & 82,1 \\
\hline TOTAL & 63 & 100,0 & 21 & 100,0 & 84 & 100,0 \\
\hline
\end{tabular}

* Herbicidas: herbicidas, dessecantes

** Classes de periculosidade: Ia - extremamente perigoso; Ib - altamente perigoso; II - moderadamente perigoso; III - levemente perigoso; U - improvável de apresentar perigo agudo sob uso normal; *** substâncias com classificação atualizada pelo guia de classificação da OMS 1988/1999 **** Novos: Ingredientes Ativos registrados após a "Lei dos Agrotóxicos"

Fontes: $\mathrm{OMS}^{81,82}$, Ministério da Saúde ${ }^{50}$, Agrofit $/ 8^{48}{ }^{4}$ Agrotis $^{1}$

\section{"Outros"}

A categoria "outros" apresentou um crescimento relativo no período de $68,0 \%$, em termos de número de ingredientes ativos registrados, entre as diferentes Classes de Uso (Tabela 13).

Como mostra a Tabela 22, as alterações entre os anos de referência, em cada classe de periculosidade, ocorreram por entrada de novas substâncias e por substâncias que deixaram de ser registradas. 
Tabela 22 - Ingredientes Ativos da Classe de Uso "outros"* que estavam registrados em 1990 e 2000, segundo a classe de periculosidade da OMS e a eliminação, reclassificação ou entrada de novos registros no período.

\begin{tabular}{|c|c|c|c|c|c|c|c|}
\hline \multirow{2}{*}{$\begin{array}{c}\text { CLASSE DE } \\
\text { PERICULOSIDADE** }\end{array}$} & \multirow[t]{2}{*}{1990} & \multirow{2}{*}{$\begin{array}{l}\text { Não mais } \\
\text { registrados }\end{array}$} & \multicolumn{2}{|c|}{$\begin{array}{c}\text { Reclassificação } \\
\text { pela OMS }\end{array}$} & \multirow{2}{*}{$\begin{array}{l}\text { Permaneceram } \\
\text { registrados } \\
\text { após } 1990 \\
\text { (classificação } \\
\text { atualizada) }\end{array}$} & \multirow[t]{2}{*}{ Novos } & \multirow[t]{2}{*}{2000} \\
\hline & & & Saídas & Entradas & & & \\
\hline $\mathbf{I a}$ & - & - & - & - & - & - & - \\
\hline Ib & - & - & - & - & - & - & - \\
\hline II & - & - & - & - & - & - & - \\
\hline III & 1 & - & - & - & 1 & 1 & 2 \\
\hline $\mathbf{U}$ & 3 & - & - & - & 3 & 2 & 5 \\
\hline $\mathbf{F}$ & - & - & - & - & - & - & - \\
\hline $\mathbf{0}$ & - & - & - & - & - & 1 & 1 \\
\hline $\mathbf{S} / \mathbf{I}$ & 21 & 1 & - & - & 20 & 14 & 34 \\
\hline TOTAL & 25 & 1 & - & - & 24 & 18 & 42 \\
\hline
\end{tabular}

* Outros: adjuvantes, antibrotantes, espalhantes adesivos, estimulantes, feromônios, reguladores de crescimento, surfactantes agrícolas;

** Classes de periculosidade: Ia - extremamente perigoso; $\quad \mathrm{Ib}$ - altamente perigoso; II - moderadamente perigoso; III - levemente perigoso; U - improvável de apresentar perigo agudo sob uso normal; $\mathrm{F}$ - fumigante; $\mathrm{O}$ - obsoleto; $\mathrm{S} / \mathrm{I}$ - sem informação

Fontes: $\mathrm{OMS}^{81,82}$, Ministério da Saúde ${ }^{50}$, Agrofit $/ 98^{48}$, Agrotis $^{1}$

Do total de ingredientes ativos que estavam registrados nos anos 1990 e 2000 , $84,0 \%$ e $81,0 \%$, respectivamente, não constavam da classificação da OMS. Como as poucas substâncias da classe "outros" classificadas pela OMS estavam todas nas classes de periculosidade III e U, não foi possível realizar a aplicação do QuiQuadrado de Tendência em Dados Ordenáveis ${ }^{66}$. 


\section{Organizacão Mundial da Saúde x Ministério da Saúde}

A Tabela 23 e a Tabela 24 mostram comparações entre as classificações informadas pelo Ministério da Saúde e pela Organização Mundial da Saúde, considerando os ingredientes ativos que estavam registrados em 2000 e para os quais ambas as classificações foi possivel obter.

Tabela 23 - Distribuição de Ingredientes Ativos que estavam registrados em 2000*, segundo a Classe Toxicológica informada pelo Ministério da Saúde (MS) e a correspondente Classe de Periculosidade informada pela Organização Mundial da Saúde (OMS).

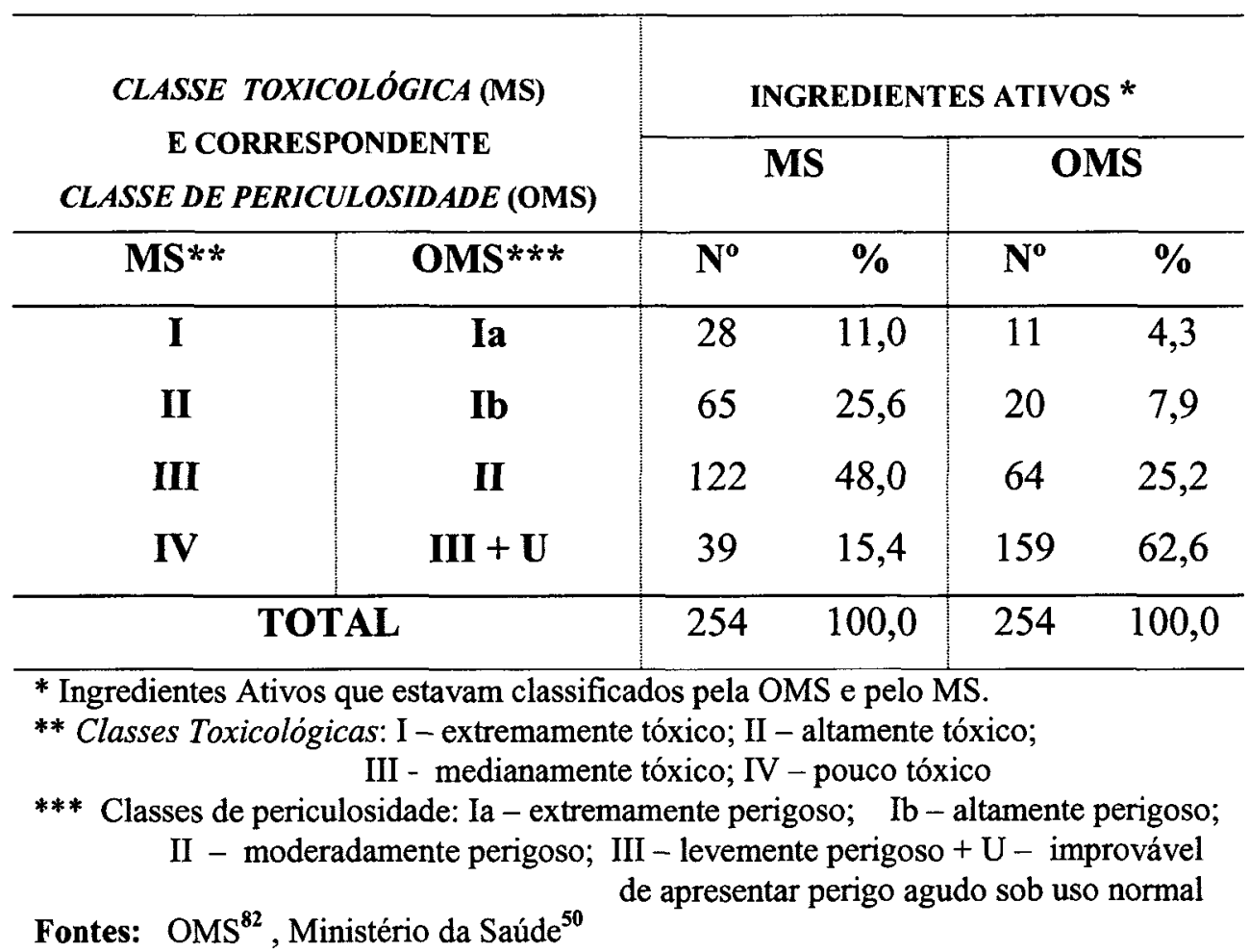

Embora os intervalos de classe de $\mathrm{DL}_{50}$ adotados pelas classificações das duas entidades sejam iguais desde $1992^{54,81}$, a classificação dos mesmos ingredientes ativos pelas duas entidades não é equivalente, conforme resultado da comparação das distribuições pelo teste de Qui-Quadrado de Tendência em Dados Ordenáveis ${ }^{66}$ (Tabela 23), que mostrou que elas são significativamente diferentes $(Z=-9,5239$ e $\mathrm{p}<0,0001)$. 
Também a avaliação da concordância entre as classificações (Tabela 24) pelo Coeficiente de Kappa ${ }^{14,40}$ mostrou baixa concordância entre as classificações dos ingredientes ativos informadas pelo Ministério da Saúde e OMS (Kappa = 0,0702; I.C. $95 \%[0,0060$ a 0,1344$] ; p=0,0185)$.

Tabela 24 - Distribuição comparativa dos Ingredientes Ativos que estavam registrados em 2000*, segundo a Classe Toxicológica informada pelo Ministério da Saúde (MS) e a correspondente Classe de Periculosidade informada pela Organização Mundial da Saúde (OMS).

\begin{tabular}{c|c|c|c|c|c}
\hline & \multicolumn{5}{|c}{ Ministério da Saúde } \\
\cline { 2 - 6 } OMS & I & II & III & IV & Total \\
\hline Ia & 10 & - & 1 & - & 11 \\
Ib & 11 & 9 & - & - & 20 \\
II & 3 & 42 & 18 & 1 & 64 \\
III + U & 4 & 14 & 103 & 38 & 159 \\
\hline Total & 28 & 65 & 122 & 39 & 254 \\
\hline
\end{tabular}

* Ingredientes Ativos que estavam classificados pela OMS e pelo MS.

Fontes: $\mathrm{OMS}^{82}$, Ministério da Saúde ${ }^{50}$ 
A Tabela 25 mostra a classificação de periculosidade, segundo a OMS, dos ingredientes ativos registrados no período após a Lei: $41,5 \%$ não constavam da classificação. Dos que constavam, a maior parte $(73,4 \%)$ estava classificado na Classe III - levemente perigoso e Classe U-improvável de apresentar perigo agudo sob uso normal.

Tabela 25 - Distribuição dos Ingredientes Ativos registrados posteriormente à "Lei dos Agrotóxicos" (Lei 7802/89), segundo a Classe de Uso e a Classe de Periculosidade definida pela Organização Mundial da Saúde - OMS.

\begin{tabular}{|c|c|c|c|c|c|c|c|c|c|c|c|c|c|c|}
\hline \multirow{3}{*}{$\begin{array}{c}\text { CLASSE } \\
\text { DE } \\
\text { USO* }\end{array}$} & \multicolumn{14}{|c|}{ CLASSE DE } \\
\hline & \multicolumn{2}{|c|}{ Ia } & \multicolumn{2}{|c|}{ Ib } & \multicolumn{2}{|c|}{ II } & \multicolumn{2}{|c|}{$\mathbf{I I I}+\mathbf{U}$} & \multicolumn{2}{|c|}{$\mathbf{0}$} & \multicolumn{2}{|c|}{$\begin{array}{c}\text { Sem } \\
\text { informação }\end{array}$} & \multicolumn{2}{|c|}{ TOTAL } \\
\hline & $\mathbf{N}^{0}$ & $\%$ & $\mathbf{N}^{o}$ & $\%$ & $\mathbf{N}^{0}$ & $\%$ & $\mathbf{N}^{\circ}$ & $\%$ & $\mathbf{N}^{\circ}$ & $\%$ & $\mathbf{N}^{\circ}$ & $\%$ & $\mathbf{N}^{\circ}$ & $\%$ \\
\hline Inseticidas & 1 & 2,3 & 2 & 4,5 & 12 & 27,3 & 15 & 34,1 & - & - & 14 & 31,8 & 44 & 100,0 \\
\hline Fungicidas & - & - & - & - & 4 & 11,8 & 20 & 58,8 & - & - & 10 & 29,4 & 34 & 100,0 \\
\hline Herbicidas & - & - & - & - & 1 & 2,6 & 20 & 51,3 & - & - & 18 & 46,2 & 39 & 100,0 \\
\hline Outros & - & - & - & - & - & - & 3 & 16,7 & 1 & 5,5 & 14 & 77,8 & 18 & 100,0 \\
\hline TOTAL & 1 & 0,7 & 2 & 1,5 & 17 & 12,6 & 58 & 43,0 & 1 & 0,7 & 56 & 41,5 & 135 & $\overline{100,0}$ \\
\hline \multicolumn{15}{|c|}{$\begin{array}{l}\text { * Classe de Uso - Inseticidas: inseticidas, acaricidas, formicidas, fumigantes, moluscicidas, nematicidas; } \\
\text { - Fungicidas: fungicidas, antibióticos, bactericidas; } \\
\text { - Herbicidas: herbicidas, dessecantes; } \\
\text { - Outros: adjuvantes, antibrotantes, espalhantes adesivos, estimulantes, feromônios, } \\
\text { reguladores de crescimento, surfactantes agrícolas. }\end{array}$} \\
\hline \multicolumn{15}{|c|}{$\begin{array}{l}\text { ** Classe de Periculosidade: Ia - extremamente perigoso; Ib - altamente perigoso; } \\
\text { II - moderadamente perigoso; III - levemente perigoso; } \\
\text { U - improvável de apresentar perigo agudo sob uso normal; } \\
\text { O - obsoleto }\end{array}$} \\
\hline
\end{tabular}


A Tabela 26 mostra a classificação toxicológica, segundo o Ministério da Saúde, dos ingredientes ativos registrados no período após a Lei. Para $12,6 \%$ das substâncias não foi possível obter a classificação. Do total das substâncias para as quais foi possível obter a classificação, 27,9\% foram classificadas na Classe I extremamente tóxico $(7,6 \%)$ e Classe II - altamente tóxico (20,3\%). Mas entre os inseticidas, $47,6 \%$ foram classificados nas Classes I (7,1\%) e II (40,5\%), de maior periculosidade.

Tabela 26 - Distribuição dos Ingredientes Ativos registrados posteriormente à "Lei dos Agrotóxicos" (Lei 7802/89), segundo a Classe de Uso e a Classe Toxicológica definida pelo Ministério da Saúde.

\begin{tabular}{|c|c|c|c|c|c|c|c|c|c|c|c|c|}
\hline \multirow{3}{*}{$\begin{array}{l}\text { CLASSE } \\
\text { DE } \\
\text { USO * }\end{array}$} & \multicolumn{12}{|c|}{ CLASSE } \\
\hline & \multicolumn{2}{|r|}{ I } & \multicolumn{2}{|c|}{ II } & \multicolumn{2}{|c|}{ III } & \multicolumn{2}{|c|}{ IV } & \multicolumn{2}{|c|}{$\begin{array}{c}\text { Sem } \\
\text { informação }\end{array}$} & \multicolumn{2}{|c|}{ TOTAL } \\
\hline & $\mathbf{N}^{0}$ & $\%$ & $\mathrm{~N}^{\circ}$ & $\%$ & $\mathbf{N}^{0}$ & $\%$ & $\mathbf{N}^{\circ}$ & $\%$ & $\mathbf{N}^{\mathbf{0}}$ & $\%$ & $\mathbf{N}^{\circ}$ & $\%$ \\
\hline Inseticidas & 3 & 6,8 & 17 & 38,6 & 10 & 22,7 & 12 & 27,3 & 2 & 4,5 & 44 & 100,0 \\
\hline Fungicidas & 4 & 11,8 & 4 & 11,8 & 17 & 50,0 & 6 & 17,6 & 3 & 8,8 & 34 & 100,0 \\
\hline Herbicidas & - & - & 3 & 7,7 & 24 & 61,5 & 9 & 23,1 & 3 & 7,7 & 39 & 100,0 \\
\hline Outros & 2 & 11,1 & - & - & 3 & 16,7 & 4 & 22,2 & 9 & 50,0 & 18 & 100,0 \\
\hline TOTAL & 9 & 6,6 & 24 & 17,8 & 54 & 40,0 & 31 & 23,0 & 17 & 12,6 & 135 & 100,0 \\
\hline \multicolumn{13}{|c|}{$\begin{array}{l}\text { * Classe de Uso - Inseticidas: inseticidas, acaricidas, formicidas, fumigantes, moluscicidas, nematicidas; } \\
\text { - Fungicidas: fungicidas, antibióticos, bactericidas; } \\
\text { - Herbicidas: herbicidas, dessecantes; } \\
\text { - Outros: adjuvantes, antibrotantes, espalhantes adesivos, estimulantes, feromônios, } \\
\text { reguladores de crescimento, surfactantes agrícolas. }\end{array}$} \\
\hline
\end{tabular}


A Tabela 27 e a Tabela 28 mostram comparações entre as classificações informadas pelo Ministério da Saúde e pela Organização Mundial da Saúde, considerando os ingredientes ativos registrados após a Lei e para os quais ambas as classificações foi possível obter.

Também neste caso, embora os intervalos de classe de $\mathrm{DL}_{50}$ adotados pelas classificações das duas entidades sejam iguais desde $1992^{54,81}$, a classificação dos mesmos ingredientes ativos pelas duas entidades não é equivalente, conforme resultado da comparação das distribuições pelo teste de Qui-Quadrado de Tendência em Dados Ordenáveis ${ }^{66}$ (Tabela 27), que mostrou que elas são significativamente diferentes $(Z=-5,8528$ e $\mathrm{p}<0,0001)$.

Tabela 27 - Distribuição dos Ingredientes Ativos* que foram registrados após a "Lei dos Agrotóxicos" (Lei 7802/89), segundo a Classe Toxicológica informada pelo Ministério da Saúde (MS) e a correspondente Classe de Periculosidade informada pela Organização Mundial da Saúde (OMS).

\begin{tabular}{|c|c|c|c|c|c|}
\hline \multirow{2}{*}{\multicolumn{2}{|c|}{$\begin{array}{c}\text { CLASSE TOXICOLÓGICA (MS) } \\
\text { E CORRESPONDENTE } \\
\text { CLASSE DE PERICULOSIDADE (OMS) }\end{array}$}} & \multicolumn{4}{|c|}{ INGREDIENTES ATIVOS * } \\
\hline & & \multicolumn{2}{|c|}{ MS } & \multicolumn{2}{|c|}{ OMS } \\
\hline MS** & OMS*** & $\mathbf{N}^{\mathbf{0}}$ & $\%$ & $\mathbf{N}^{0}$ & $\%$ \\
\hline $\mathbf{I}$ & Ia & 5 & 6,7 & 1 & 1,3 \\
\hline II & Ib & 17 & 22,7 & 2 & 2,7 \\
\hline III & II & 34 & 45,3 & 16 & 21,3 \\
\hline IV & $\mathbf{I I I}+\mathbf{U}$ & 19 & 25,3 & 56 & 74,7 \\
\hline \multicolumn{2}{|c|}{ TOTAL } & 75 & 100,0 & 75 & 100,0 \\
\hline \multicolumn{6}{|c|}{$\begin{array}{l}\text { * Ingredientes Ativos que estavam classificados pela OMS e pelo MS. } \\
\text { ** Classes Toxicológicas: I - extremamente tóxico; II - altamente tóxico; } \\
\text { III - medianamente tóxico; IV - pouco tóxico } \\
\text { *** Classes de periculosidade: Ia - extremamente perigoso; Ib - altamente perigoso; } \\
\text { II - moderadamente perigoso; III - levemente perigoso + U - improvável } \\
\text { de apresentar perigo agudo sob uso normal } \\
\text { Fontes: } \mathrm{OMS}^{81,82}, \text { Ministério da Saúde }^{50}, \text { Agrofit } / 98^{48}, \text { Agrotis }\end{array}$} \\
\hline
\end{tabular}


A avaliação da concordância pelo Coeficiente de Kappa ${ }^{14}$ entre as classificações dos ingredientes ativos registrados no período após a Lei, informadas pelo Ministério da Saúde e OMS (Tabela 28), mostrou que não há concordância estatística entre as classificações (Kappa $=0,0950$; I.C. 95\% [-0,0132 a 0,2032]; $p=0,0974)$.

Tabela 28 - Distribuição comparativa dos Ingredientes Ativos* registrados posteriormente à "Lei dos Agrotóxicos" (Lei 7802/89), segundo a Classe Toxicológica informada pelo Ministério da Saúde (MS) e a correspondente Classe de Periculosidade informada pela Organização Mundial da Saúde (OMS).

\begin{tabular}{c|c|c|c|c|c}
\hline \multirow{2}{*}{ OMS } & \multicolumn{6}{|c}{ Ministério da Saúde } \\
\cline { 2 - 7 } & I & II & III & IV & Total \\
\hline Ia & 1 & - & - & - & 1 \\
Ib & - & 2 & - & - & 2 \\
II & 1 & 10 & 5 & - & 16 \\
III + U & 3 & 5 & 29 & 19 & 56 \\
\hline Total & 5 & 17 & 34 & 19 & 75 \\
\hline
\end{tabular}

* Ingredientes Ativos que estavam classificados pela OMS e pelo MS.

Fontes: $\mathrm{OMS}^{81,82}$, Ministério da Saúde ${ }^{50}$, Agrofit $/ 98^{48}$, Agrotis ${ }^{1}$ 


\section{Objetivo específico $n^{0} 4$}

A Tabela 29 apresenta a distribuição geral, segundo a Classe de Uso, dos produtos comerciais que foram identificados como estando registrados no ano de 1990, dos que foram registrados após a "Lei dos Agrotóxicos" e do total que estava registrado em 2000.

\begin{tabular}{|c|c|c|c|c|c|c|c|}
\hline \multirow{2}{*}{$\begin{array}{c}\text { CLASSE DE } \\
\text { USO * }\end{array}$} & \multicolumn{2}{|c|}{1990} & \multicolumn{2}{|c|}{ NOVOS ${ }^{* \star}$} & \multicolumn{2}{|c|}{2000} & \multirow{2}{*}{$\begin{array}{c}\begin{array}{c}\text { Aumento } \\
\text { relativo } \\
\text { no período }\end{array} \\
\% \\
\end{array}$} \\
\hline & $\mathbf{N}^{0}$ & $\%$ & $\mathbf{N}^{o}$ & $\%$ & $\mathbf{N}^{o}$ & $\%$ & \\
\hline Inseticidas & 237 & 40,6 & 194 & 42,1 & 350 & 40,6 & 47,7 \\
\hline Fungicidas & 132 & 22,6 & 90 & 19,5 & 186 & 21,6 & 40,9 \\
\hline Herbicidas & 179 & 30,7 & 149 & 32,3 & 278 & 32,2 & 55,3 \\
\hline Outros & 36 & 6,2 & 28 & 6,1 & 49 & 5,7 & 36,1 \\
\hline TOTAL & 584 & 100,0 & 461 & 100,0 & 863 & 100,0 & 47,8 \\
\hline \multicolumn{8}{|c|}{ 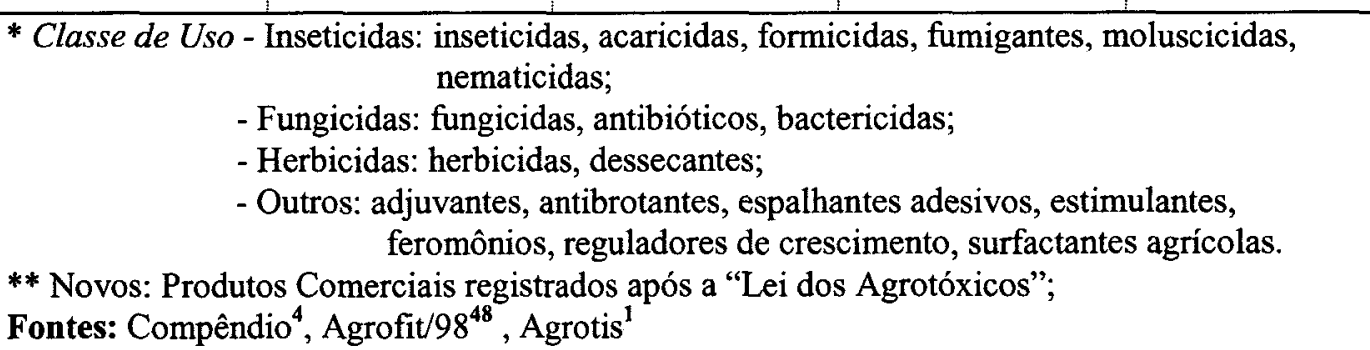 } \\
\hline
\end{tabular}

Dos 584 produtos que estavam registrados em 1990, 182 não se encontravam mais registrados em 2000. Portanto, dos 863 produtos que foram identificados como registrados em 2000, $402(46,6 \%)$ haviam sido registrados antes da "Lei dos Agrotóxicos". Pela Tabela 29, o aumento no número de registros de produtos comerciais no período analisado foi de $47,8 \%$. Os inseticidas foram a classe com maior número de produtos comerciais registrados no período após a Lei, seguidos, 
em ordem decrescente, pelos herbicidas, fungicidas e "outros". Porém, os herbicidas tiveram um maior aumento proporcional no período $(55,3 \%)$. As diferenças de crescimento entre as Classes de Uso, no entanto, não foram suficientes para alterar significativamente a distribuição proporcional de registros entre as mesmas, Aplicando o teste do Qui-Quadrado de Tendência em Dados Ordenáveis ${ }^{65,66}$, não foi constatada diferença estatisticamente significativa entre a distribuição dos produtos, segundo a Classe de Uso, que estavam registrados antes da "Lei dos Agrotóxicos" e os "novos", que foram registrados após a mesma $(Z=0,0018$ e p $<0,9986)$. Tampouco foi encontrada diferença nas distribuições dos produtos comerciais, segundo a Classe de Uso, entre os anos de 1990 e $2000(Z=-0,1175$ e $\mathrm{p}<0,9065)$.

A Tabela 30 apresenta a época de registro dos ingredientes ativos dos produtos comerciais que estavam registrados em 2000.

Tabela 30 - Distribuição dos Produtos Comerciais que se encontravam registrados em 2000, segundo a Classe de Uso e a época de registro dos seus Ingredientes Ativos.

\begin{tabular}{ccccccc}
\hline CLASSE & $\begin{array}{c}\text { Derivados de } \\
\text { Ingredientes }\end{array}$ & $\begin{array}{c}\text { Derivados de } \\
\text { Ingredientes }\end{array}$ & TOTAL \\
& \multicolumn{2}{c}{$\begin{array}{c}\text { Ativos } \\
\text { “antigos" ** }\end{array}$} & \multicolumn{2}{c}{$\begin{array}{c}\text { Ativos } \\
\text { “novos" *** }\end{array}$} & & \\
\cline { 2 - 7 } & $\mathbf{N}^{\mathbf{0}}$ & $\%$ & $\mathbf{N}^{\mathbf{0}}$ & $\%$ & $\mathbf{N}^{\mathbf{0}}$ & $\%$ \\
\hline Inseticidas & 267 & 76,3 & 83 & 23,7 & 350 & 100,0 \\
Fungicidas & 147 & 79,0 & 39 & 21,0 & 186 & 100,0 \\
Herbicidas & 227 & 81,7 & 51 & 18,3 & 278 & 100,0 \\
Outros & 34 & 69,4 & 15 & 30,6 & 49 & 100,0 \\
\hline TOTAL & 675 & 78,2 & 188 & 21,8 & 863 & 100,0 \\
\hline
\end{tabular}

* Classe de Uso - Inseticidas: inseticidas, acaricidas, formicidas, fumigantes, moluscicidas, nematicidas;

- Fungicidas: fungicidas, antibióticos, bactericidas;

- Herbicidas: herbicidas, dessecantes;

- Outros: adjuvantes, antibrotantes, espalhantes adesivos, estimulantes, feromônios, reguladores de crescimento, surfactantes agrícolas.

** "antigos" - registro anterior à Lei;

** "novos" - registro posterior à Lei.

Fontes: Compêndio ${ }^{4}$, Agrofit $/ 98^{48}$, Agrotis ${ }^{1}$ 
Considerando o conjunto dos produtos comerciais que estavam registrados em 2000, é possível observar, pela Tabela 30, que apenas uma minoria $(21,8 \%)$ era derivada de ingredientes ativos que foram registrados após a "Lei dos Agrotóxicos".

Considerando apenas os produtos comerciais registrados no periodo após a Lei, a Tabela 31 mostra que 41,4\% deles ainda estão nas Classes Toxicológicas I e II, de maior periculosidade. Considerada separadamente, na classe dos inseticidas essa proporção chega a $49,5 \%$.

Tabela 31 - Distribuição dos Produtos Comerciais registrados posteriormente à "Lei dos Agrotóxicos" (Lei 7802/89), segundo Classe de Uso e a Classe Toxicológica definida pelo Ministério da Saúde.

\begin{tabular}{|c|c|c|c|c|c|c|c|c|c|c|}
\hline \multirow{3}{*}{$\begin{array}{c}\text { CLASSE } \\
\text { DE } \\
\text { USO * }\end{array}$} & \multicolumn{10}{|c|}{ CLASSE } \\
\hline & \multicolumn{2}{|r|}{ I } & \multicolumn{2}{|c|}{ II } & \multicolumn{2}{|c|}{ III } & \multicolumn{2}{|c|}{ IV } & \multicolumn{2}{|c|}{ TOTAL } \\
\hline & $\mathrm{N}^{0}$ & $\%$ & $\mathbf{N}^{0}$ & $\%$ & $N^{0}$ & $\%$ & $\mathbf{N}^{\mathbf{0}}$ & $\%$ & $\mathbf{N}^{0}$ & $\%$ \\
\hline Inseticidas & 49 & 25,3 & 47 & 24,2 & 41 & 21,1 & 57 & 29,4 & 194 & 100,0 \\
\hline Fungicidas & 11 & 12,2 & 14 & 15,6 & 33 & 36,7 & 32 & 35,6 & 90 & 100,0 \\
\hline Herbicidas & 20 & 13,4 & 39 & 22,6 & 57 & 38,3 & 33 & 22,1 & 149 & 100,0 \\
\hline Outros & 4 & 14,3 & 7 & 25,0 & 5 & 17,9 & 12 & 42,9 & 28 & 100,0 \\
\hline TOTAL & 84 & 18,2 & 107 & 23,2 & 136 & 29,5 & 134 & 29,1 & 461 & 100,0 \\
\hline \multicolumn{11}{|c|}{$\begin{array}{l}\text { * Classe de Uso - Inseticidas: inseticidas, acaricidas, formicidas, fumigantes, moluscicidas, } \\
\text { nematicidas; } \\
\text { - Fungicidas: fungicidas, antibióticos, bactericidas; } \\
\text { - Herbicidas: herbicidas, dessecantes; } \\
\text { - Outros: adjuvantes, antibrotantes, espalhantes adesivos, estimulantes, feromônios, } \\
\text { reguladores de crescimento, surfactantes agrícolas. } \\
\text { ** Classes Toxicológicas: I - extremamente tóxico; II - altamente tóxico; } \\
\text { III - medianamente tóxico; IV - pouco tóxico } \\
\text { Fontes: Ministério da Saúde Agrofit } / 98^{88} \text { Agrotis }{ }^{1} \text {. }\end{array}$} \\
\hline
\end{tabular}


Como pode ser observado na Tabela 33, 59,2\% dos produtos comerciais registrados após a "Lei dos Agrotóxicos" eram derivados de ingredientes ativos “antigos”, ou seja, que já estavam registrados anteriormente. Entre os herbicidas essa proporção chega a $65,8 \%$. Apenas na categoria "outros" a proporção de produtos derivados dos "novos" ingredientes ativos é maior que a dos "antigos".

Tabela 33 - Distribuição dos Produtos Comerciais registrados após a "Lei dos Agrotóxicos" (Lei 7802/89), segundo as Classe de Uso e a época de registro dos seus Ingredientes Ativos.

\begin{tabular}{|c|c|c|c|c|c|c|}
\hline \multirow[t]{2}{*}{$\begin{array}{l}\text { CLASSE } \\
\text { DE USO * }\end{array}$} & \multicolumn{2}{|c|}{$\begin{array}{l}\text { Derivados de } \\
\text { Ingredientes } \\
\text { Ativos } \\
\text { "antigos" ** }\end{array}$} & \multicolumn{2}{|c|}{$\begin{array}{l}\text { Derivados de } \\
\text { Ingredientes } \\
\text { Ativos } \\
\text { "novos" *** }\end{array}$} & \multicolumn{2}{|c|}{ TOTAL } \\
\hline & $\mathbf{N}^{0}$ & $\%$ & $\mathbf{N}^{0}$ & $\%$ & $\mathbf{N}^{0}$ & $\%$ \\
\hline Inseticidas & 111 & 57,2 & 83 & 42,8 & 194 & 100,0 \\
\hline Fungicidas & 51 & 56,7 & 39 & 43,3 & 90 & 100,0 \\
\hline Herbicidas & 98 & 65,8 & 51 & 34,2 & 149 & 100,0 \\
\hline Outros & 13 & 46,4 & 15 & 53,6 & 28 & 100,0 \\
\hline TOTAL & 273 & 59,2 & 188 & 40,8 & 461 & 100,0 \\
\hline $\begin{array}{r}-\mathrm{Fu} \\
-\mathrm{He} \\
-\mathrm{Ou} \\
* * \text { "antigo" - regist } \\
* * * \text { "novos" - regi } \\
\text { Fontes: Compêndi }\end{array}$ & $\begin{array}{l}\text { idas: ins } \\
\text { mo } \\
\text { das: fur } \\
\text { das: her } \\
\text { adjuva } \\
\text { estim } \\
\text { surfac } \\
\text { terior à } \\
\text { osterio } \\
\text { grofit/9 }\end{array}$ & $\begin{array}{l}\text { das, a } \\
\text { icidas } \\
\text { das, ar } \\
\text { das, de } \\
\text { antibr } \\
\text { es, fer } \\
\text { s agri }\end{array}$ & $\begin{array}{l}\text { icidas, } \mathrm{f} \\
\text { ematicic } \\
\text { ióticos, } \\
\text { cantes; } \\
\text { ntes, es } \\
\text { ônios, r } \\
\text { as. }\end{array}$ & $\begin{array}{l}\text { icidas, } \\
\text { tericida } \\
\text { antes a } \\
\text { ladores }\end{array}$ & $\begin{array}{l}\text { nigant } \\
\text { sivos, } \\
\text { cresci }\end{array}$ & \\
\hline
\end{tabular}


A Tabela 34 compara a classificação toxicológica dos produtos comerciais derivados dos ingredientes ativos "antigos" com a dos "novos", registrados no período após a Lei.

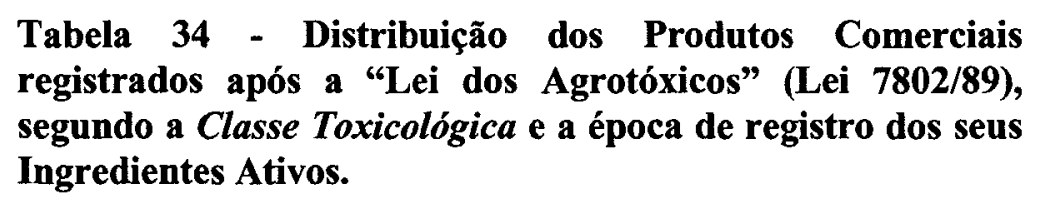

Tabela 34 - Distribuição dos Produtos Comerciais registrados após a "Lei dos Agrotóxicos" (Lei 7802/89), segundo a Classe Toxicológica e a época de registro dos seus Ingredientes Ativos.

\begin{tabular}{|c|c|c|c|c|}
\hline \multirow[t]{2}{*}{$\begin{array}{c}\text { CLASSE } \\
\text { TOXICOLÓGICA* }\end{array}$} & \multicolumn{2}{|c|}{$\begin{array}{c}\text { Derivados de } \\
\text { Ingredientes } \\
\text { Ativos } \\
\text { "antigos"** }\end{array}$} & \multicolumn{2}{|c|}{$\begin{array}{c}\text { Derivados de } \\
\text { Ingredientes } \\
\text { Ativos } \\
\text { "novos"*** }\end{array}$} \\
\hline & $\mathbf{N}^{0}$ & $\%$ & $\mathbf{N}^{0}$ & $\%$ \\
\hline I & 53 & 19,4 & 31 & 16,5 \\
\hline II & 69 & 25,3 & 38 & 20,2 \\
\hline III & 79 & 28,9 & 57 & 30,3 \\
\hline IV & 72 & 26,4 & 62 & 33,0 \\
\hline TOTAL & 273 & 100,0 & 188 & 100,0 \\
\hline $\begin{array}{l}\text { *Classes Toxicológicas: } \\
\text { tóxico; III - medianamen } \\
\text { ** "antigo"- - registro ant } \\
\text { *** "novos"- registro po } \\
\text { Fontes: Ministério da Saú }\end{array}$ & $\begin{array}{l}\text { xico; } \\
\text { à Le } \\
\text { or à } 1 \\
\text { Agrof }\end{array}$ & $\begin{array}{l}\text { ente tóxic } \\
\text { - pouco t } \\
8^{48}, \text { Agro }\end{array}$ & $\begin{array}{l}\text { II - } \\
\text { co; }\end{array}$ & \\
\hline
\end{tabular}

Embora entre os derivados de ingredientes ativos "novos" haja proporcionalmente um número um pouco maior de produtos classificados nas classes de menor periculosidade, aplicando o teste do Qui-Quadrado de Tendência em Dados Ordenáveis ${ }^{65,}{ }^{66}$, não foi constatada diferença estatisticamente significativa entre a distribuição, segundo a Classe Toxicológica, dos produtos derivados dos ingredientes ativos "antigos", que estavam registrados antes da "Lei dos Agrotóxicos" e a dos "novos", que foram registrados após a mesma $(Z=-1,7174$ e $\mathrm{p}<0,0859$ ). 
Dos 461 produtos comerciais identificados como registrados no período após a Lei, 59,2\% eram derivados de ingredientes ativos "antigos". Pela Tabela 35, observa-se que $44,7 \%$ desses produtos comerciais registrados no período após a Lei mas derivados de ingredientes ativos "antigos" foram classificados nas Classes Toxicológicas I e II, de maior periculosidade. $\mathrm{Na}$ classe dos inseticidas essa proporção chega a $59,4 \%$.

Tabela 35 - Distribuição dos Produtos Comerciais registrados posteriormente à "Lei dos Agrotóxicos" (Lei 7802/89), derivados dos Ingredientes Ativos que já estavam registrados em 1990, segundo a Classe de Uso e a Classe Toxicológica definida pelo Ministério da Saúde.

\begin{tabular}{|c|c|c|c|c|c|c|c|c|c|c|}
\hline \multirow{3}{*}{$\begin{array}{c}\text { CLASSE } \\
\text { DE } \\
\text { USO * }\end{array}$} & \multicolumn{10}{|c|}{ CLASSE } \\
\hline & \multicolumn{2}{|c|}{ I } & \multicolumn{2}{|c|}{ II } & \multicolumn{2}{|c|}{ III } & \multicolumn{2}{|c|}{ IV } & \multicolumn{2}{|c|}{ TOTAL } \\
\hline & $\mathbf{N}^{\circ}$ & $\%$ & $\mathbf{N}^{0}$ & $\%$ & $\mathbf{N}^{0}$ & $\%$ & $\mathbf{N}^{0}$ & $\%$ & $\mathbf{N}^{0}$ & $\%$ \\
\hline Inseticidas & 32 & 28,8 & 34 & 30,6 & 23 & 20,7 & 22 & 19,8 & 111 & 100,0 \\
\hline Fungicidas & 7 & 13,7 & 3 & 5,9 & 19 & 37,3 & 22 & 43,1 & 51 & 100,0 \\
\hline Herbicidas & 11 & 11,2 & 28 & 28,6 & 37 & 37,8 & 22 & 22,4 & 98 & 100,0 \\
\hline Outros & 3 & 23,1 & 4 & 30,8 & - & - & 6 & 46,2 & 13 & 100,0 \\
\hline TOTAL & 53 & 19,4 & 69 & 25,3 & 79 & 28,9 & 72 & 26,4 & 273 & 100,0 \\
\hline \multicolumn{11}{|c|}{$\begin{array}{l}\text { * Classe de Uso - Inseticidas: inseticidas, acaricidas, formicidas, fumigantes, moluscicidas, } \\
\text { nematicidas; } \\
\text { - Fungicidas: fungicidas, antibióticos, bactericidas; } \\
\text { - Herbicidas: herbicidas, dessecantes; } \\
\text { - Outros: adjuvantes, antibrotantes, espalhantes adesivos, estimulantes, feromônios, } \\
\text { reguladores de crescimento, surfactantes agricolas. }\end{array}$} \\
\hline
\end{tabular}


Com relação à Classe de Potencial de Periculosidade Ambiental, a Tabela 36 nos mostra que, entre os produtos comerciais derivados dos "antigos" ingredientes ativos não foi possível obter a informação da classificação ambiental para 30,4\% deles. Entre os que dispunham desta informação, a maior proporção $(50,0 \%)$ foi classificada na Classe II - Produto Muito Perigoso.

Tabela 36 - Distribuição dos Produtos Comerciais registrados posteriormente à "Lei dos Agrotóxicos" (Lei 7802/89), derivados dos Ingredientes Ativos que já estavam registrados em 1990, segundo a Classe de Uso e a Classe de Potencial de Periculosidade Ambiental definida pelo IBAMA.

\begin{tabular}{|c|c|c|c|c|c|c|c|c|c|c|c|c|}
\hline \multirow{3}{*}{$\begin{array}{c}\text { CLASSE } \\
\text { DE } \\
\text { USO * }\end{array}$} & \multicolumn{12}{|c|}{ CLASSE DE POTENCLAL DE PERICULOSIDADE AMBIENTAL ** } \\
\hline & \multicolumn{2}{|c|}{ I } & \multicolumn{2}{|c|}{ II } & \multicolumn{2}{|c|}{ III } & \multicolumn{2}{|c|}{ IV } & \multicolumn{2}{|c|}{ S / INF } & \multicolumn{2}{|c|}{ TOTAL } \\
\hline & $\mathbf{N}^{\circ}$ & $\%$ & $\mathrm{~N}^{0}$ & $\%$ & $\mathbf{N}^{\mathbf{0}}$ & $\%$ & $\mathrm{~N}^{0}$ & $\%$ & $\mathbf{N}^{\circ}$ & $\%$ & $\mathbf{N}^{\mathbf{0}}$ & $\%$ \\
\hline Inse & 13 & 11,7 & 35 & 31,5 & 8 & 7,2 & 14 & 12 & 1 & 9 & 11 & 100,0 \\
\hline Fung & 5 & 9,8 & 17 & 3. & 14 & 27 & & & & & & 100,0 \\
\hline Her & 8 & 8,2 & 42 & 42 & 20 & & & & & & 3 & 100,0 \\
\hline Outros & - & - & 1 & 7,7 & 8 & 61, & 1 & 7,7 & 3 & 3,1 & 13 & 100,0 \\
\hline TOTAL & 26 & 9,5 & 95 & 34,8 & 50 & 18,3 & 19 & 7,0 & 83 & 30,4 & 273 & 100,0 \\
\hline \multicolumn{13}{|c|}{$\begin{array}{l}\text { * Classe de Uso - Inseticidas: inseticidas, acaricidas, formicidas, fumigantes, moluscicidas, nematicidas; } \\
\text { - Fungicidas: fungicidas, antibióticos, bactericidas; } \\
\text { - Herbicidas: herbicidas, dessecantes; } \\
\text { - Outros: adjuvantes, antibrotantes, espalhantes adesivos, estimulantes, feromônios, } \\
\text { reguladores de crescimento, surfactantes agrícolas. } \\
\text { (II - Produto Perigoso; IV - Produto Pouco Perigoso; S/INF - sem informação }\end{array}$} \\
\hline
\end{tabular}


Dos produtos comerciais identificados como registrados após a "Lei dos Agrotóxicos", 188 (40,8\%) eram derivados de "novos" ingredientes ativos, ou seja, substâncias que foram registradas posteriormente à Lei. Quando analisados separadamente, observa-se que, na classificação toxicológica (Tabela 37), 36,7\% foram classificados nas classes I e II, de maior periculosidade. Entre as Classes de Uso, os herbicidas são os que apresentam maior freqüência nas classes I e II $(39,2 \%)$, seguidos pelos fungicidas $(38,5 \%)$ e pelos inseticidas $(36,2 \%)$.

Tabela 37 - Distribuição dos Produtos Comerciais registrados posteriormente à "Lei dos Agrotóxicos" (Lei 7802/89), derivados dos novos* Ingredientes Ativos, segundo a Classe de Uso e a Classe Toxicológica definida pelo Ministério da Saúde.

\begin{tabular}{|c|c|c|c|c|c|c|c|c|c|c|}
\hline \multirow{3}{*}{$\begin{array}{c}\text { CLASSE } \\
\text { DE } \\
\text { USO } * *\end{array}$} & \multicolumn{10}{|c|}{ CLASSE } \\
\hline & \multicolumn{2}{|c|}{ I } & \multicolumn{2}{|c|}{ II } & \multicolumn{2}{|c|}{ III } & \multicolumn{2}{|c|}{ IV } & \multicolumn{2}{|c|}{ TOTAL } \\
\hline & $\mathbf{N}^{\mathbf{0}}$ & $\%$ & $\mathbf{N}^{0}$ & $\%$ & $\mathbf{N}^{\mathbf{0}}$ & $\%$ & $\mathbf{N}^{\mathbf{0}}$ & $\%$ & $\mathbf{N}^{\mathbf{0}}$ & $\%$ \\
\hline Inseticidas & 17 & 20,5 & 13 & 15,7 & 18 & 21,7 & 35 & 42,2 & 83 & 100,0 \\
\hline Fungicidas & 4 & 10,3 & 11 & 28,2 & 14 & 35,9 & 10 & 25,6 & 39 & 100,0 \\
\hline Herbicidas & 9 & 17,6 & 11 & 21,6 & 20 & 39,2 & 11 & 21,6 & 51 & 100,0 \\
\hline Outros & 1 & 6,7 & 3 & 20,0 & 5 & 33,3 & 6 & 40,0 & 15 & 100,0 \\
\hline TOTAL & 31 & 16,5 & 38 & 20,2 & 57 & 30,3 & 62 & 33,0 & 188 & 100,0 \\
\hline \multicolumn{11}{|c|}{$\begin{array}{l}\text { * novos: Ingredientes Ativos registrados posteriormente à "Lei dos Agrotóxicos" (Lei 7802/89), } \\
\text { ** Classe de Uso - Inseticidas: inseticidas, acaricidas, formicidas, fumigantes, moluscicidas, } \\
\quad \text { nematicidas; } \\
\text { - Fungicidas: fungicidas, antibióticos, bactericidas; } \\
\text { - Herbicidas: herbicida, dessecantes; } \\
\text { - Outros: adjuvantes, antibrotantes, espalhantes adesivos, estimulantes, feromônios, } \\
\text { reguladores de crescimento, surfactantes agrícolas. }\end{array}$} \\
\hline *** Classes & & icas: & & A & & $\begin{array}{l}\text { II - } \\
\text { IV - }\end{array}$ & & xico; & & \\
\hline
\end{tabular}


Com relação à Classe de Potencial de Periculosidade Ambiental, a Tabela 38 nos mostra que não foi possível obter a informação da classificação ambiental para $7,4 \%$ dos produtos comerciais derivados dos "novos" ingredientes ativos. Entre os que dispunham desta informação, a maior proporção $(47,7 \%)$ foi classificada na Classe II - Produto Muito Perigoso.

Tabela 38 - Distribuição dos Produtos Comerciais registrados posteriormente à "Lei dos Agrotóxicos" (Lei 7802/89), derivados dos novos" Ingredientes Ativos, segundo a Classe de Uso e a Classe de Potencial de Periculosidade Ambiental definida pelo IBAMA.

\begin{tabular}{|c|c|c|c|c|c|c|c|c|c|c|c|c|}
\hline \multirow{3}{*}{$\begin{array}{c}\text { CLASSE } \\
\text { DE } \\
\text { USO ** }\end{array}$} & \multicolumn{12}{|c|}{ CLASSE DE POTENCIAL DE PERICULOSIDADE AMBIENTAL *** } \\
\hline & \multicolumn{2}{|c|}{ I } & \multicolumn{2}{|c|}{ II } & \multicolumn{2}{|c|}{ III } & \multicolumn{2}{|c|}{ IV } & \multicolumn{2}{|c|}{ S / INF } & \multicolumn{2}{|c|}{ TOTAL } \\
\hline & $\mathbf{N}^{0}$ & $\%$ & $\mathbf{N}^{0}$ & $\%$ & $\mathbf{N}^{0}$ & $\%$ & $\mathbf{N}^{\circ}$ & $\%$ & $\mathrm{~N}^{0}$ & $\%$ & $\mathbf{N}^{\circ}$ & $\%$ \\
\hline Inseticidas & 11 & 13, & 33 & 39,8 & 21 & 25,3 & 12 & 14,5 & 6 & 7,2 & 83 & 100,0 \\
\hline Fungicidas & 1 & 2,6 & 27 & 69,2 & 8 & 20,5 & 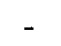 & 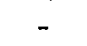 & 3 & 7,7 & 39 & 100,0 \\
\hline Herbicidas & 3 & 5,9 & 20 & 39,2 & 24 & 47,1 & - & 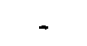 & 4 & 7,8 & 51 & 00,0 \\
\hline Outros & - & 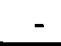 & 3 & 20,0 & 4 & 26,7 & 7 & 46,7 & 1 & 6,7 & 15 & 100,0 \\
\hline TOTAL & 15 & 8,0 & 83 & 44,1 & 57 & 30,3 & 19 & 10,1 & 14 & 7,4 & 188 & 100,0 \\
\hline \multicolumn{13}{|c|}{$\begin{array}{l}\text { * novos: Ingredientes Ativos registrados posteriormente à "Lei dos Agrotóxicos" (Lei 7802/89). } \\
\text { (** Classe de Uso - Inseticidas: inseticidas, acaricidas, formicidas, fumigantes, moluscicidas, } \\
\text { nematicidas; } \\
\text { - Fungicidas: fungicidas, antibióticos, bactericidas; } \\
\text { - Herbicidas: herbicidas, dessecantes; } \\
\text { - Outros: adjuvantes, antibrotantes, espalhantes adesivos, estimulantes, feromônios, } \\
\text { reguladores de crescimento, surfactantes agrícolas. } \\
\text { (II - Produto Perigoso; IV - Produto Pouco Perigoso; S/INF - sem informação } \\
\text { ** Classes Ambientais: I - Produto Altamente Perigoso; II - Produto Muito Perigoso; }\end{array}$} \\
\hline
\end{tabular}


A Figura 6 apresenta as proporções de produtos comerciais registrados no período após a Lei nas Classes Toxicológicas I e II segundo a anterioridade ou posterioridade à Lei do registro do ingrediente ativo do mesmo. Nas Classes de Uso de inseticidas, "outros" e no total, os derivados dos "novos" ingredientes ativos têm proporcionalmente menos registros nas Classes Toxicológicas I $e$ II. Entre os herbicidas, praticamente não há diferença entre "novos" e "antigos". Já na classe dos fungicidas, a maior proporção de registros de produtos nas Classes $\mathrm{I} e \mathrm{II}$, de maior periculosidade, ocorre com aqueles derivados de "novos" ingredientes ativos.

Figura 6 - Proporções de Produtos Comerciais registrados após a "Lei dos Agrotóxicos" (Lei 7802/89) nas Classes Toxicológicas I e II, segundo a Classe de Uso e a época de registro do Ingrediente Ativo.

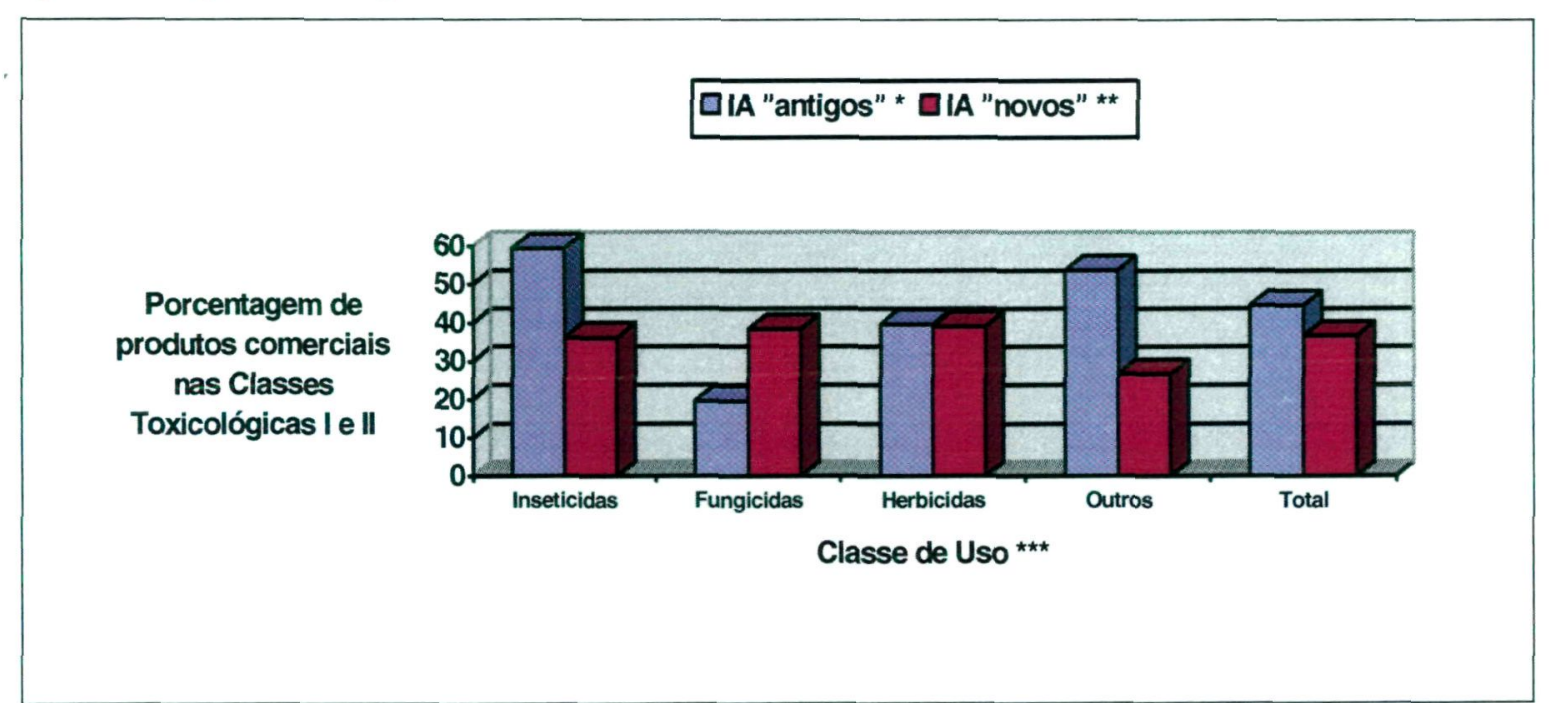

* IA "antigos": Ingredientes Ativos com registro anterior à Lei;

** IA "novos" : Ingredientes Ativos com registro posterior à Lei;

*** Classes de Uso

- Inseticidas: inseticidas, acaricidas, formicidas, fumigantes, moluscicidas, nematicidas;

- Fungicidas: fungicidas, antibióticos, bactericidas;

- Herbicidas: herbicidas, dessecantes;

- Outros: adjuvantes, antibrotantes, espalhantes adesivos, estimulantes, feromônios, reguladores de crescimento, surfactantes agrícolas.

Fontes: Ministério da Saúde, Compêndio ${ }^{4}$, Agrofit $/ 98^{48}$, Agrotis ${ }^{1}$ 


\section{Objetivo específico $\mathbf{n}^{\circ} 5$}

A Tabela 39 mostra o comportamento do número de registros de produtos comerciais segundo as culturas/produtos de destinação, no período em estudo. Foram identificadas 86 culturas/produtos de destinação que receberam registros no periodo de referência. As culturas/produtos de destinação que receberam maìs de 40 registros no período foram, em ordem decrescente: ornamentais (145 registros), soja (143), algodão (134), tomate (116), citros (112), milho (107), feijão (99), café (98), arroz (83), batata (83), trigo (79), cana-de-açúcar (62), maçã (61), amendoim (49), uva (46), cebola (46) e fumo (42). Estas culturas já eram basicamente as que contavam com o maior número de registros antes da Lei e, apesar de também se encontrarem entre as que perderam mais registros, devido ao alto número de registros efetuados no período em estudo, ainda encontravam-se em 2000 com 100 ou mais produtos registrados: algodão (274 registros), soja (262), café (246), citros (245), tomate (235), ornamentais (224), feijão (210), milho (198), trigo (197), arroz (167), batata (164), cana-de-açúcar (145), amendoim (144), maçã (135), uva (108), fumo (103), cebola (100). Foram identificadas 38 culturas/produtos de destinação que receberam 10 ou menos registros no período. Identificaram-se, também, 45 culturas/produtos de destinação para as quais não foi localizado nenhum registro e 57 culturas/produtos de destinação que tiveram decréscimo do número de registros no período. 
Tabela 39 - Distribuição do número de Produtos Comerciais que estavam registrados em 1990 e 2000, segundo a cultura/produto de destinação, a eliminação, a entrada e o crescimento de registros identificados no período.

\begin{tabular}{|c|c|c|c|c|c|}
\hline $\begin{array}{l}\text { CULTURAPRODUTO } \\
\text { DE DESTINAÇÃO }\end{array}$ & 1990 & SAÍDA & NOVOS & 2000 & $\begin{array}{c}\text { CRESC. } \\
\%\end{array}$ \\
\hline ORNAMENTAIS & 114 & 35 & 145 & 224 & 96,5 \\
\hline SOJA & 166 & 47 & 143 & 262 & 57.8 \\
\hline ALGODÃO & 196 & 56 & 134 & 274 & 39,8 \\
\hline TOMATE & 164 & 45 & 116 & 235 & 43,3 \\
\hline CITROS & 195 & 62 & 112 & 245 & 25,6 \\
\hline MILHO & 125 & 34 & 107 & 198 & 58,4 \\
\hline FEIJĀO & 153 & 42 & 99 & 210 & 37,3 \\
\hline $\overrightarrow{C A F E}$ & 187 & 39 & 98 & 246 & 31,6 \\
\hline ARROZ & 126 & 42 & 83 & 167 & 32,5 \\
\hline BATATA & 112 & 31 & 83 & 164 & 46,4 \\
\hline TRIGO & 163 & 45 & 79 & 197 & 20,9 \\
\hline CANA-DE-ACCÚCAR & 111 & 28 & 62 & 145 & 30,6 \\
\hline MAÇÄ & 111 & 37 & 61 & 135 & 21,6 \\
\hline AMENDOIM & 136 & 41 & 49 & 144 & 5,9 \\
\hline CEBOLA & 81 & 27 & 46 & 100 & 23,5 \\
\hline UVA & 91 & 29 & 46 & 108 & 18,7 \\
\hline FUMO & 92 & 31 & 42 & 103 & 12,0 \\
\hline PEPINO & 80 & 28 & 31 & 83 & 3,8 \\
\hline ALHO & 65 & 18 & 30 & 77 & 18,5 \\
\hline BANANA & 67 & 20 & 30 & 77 & 14,9 \\
\hline REPOLHO & 68 & 22 & 30 & 76 & 11,8 \\
\hline MELÁO & 79 & 28 & 28 & 79 & 0,0 \\
\hline PIMENTÃO & 79 & 24 & 27 & 82 & 3,8 \\
\hline CENOURA & 65 & 17 & 26 & 74 & 13,8 \\
\hline COUVE & 76 & 22 & 26 & 80 & 5,3 \\
\hline PESSEGO & 84 & 37 & 26 & 73 & $-13,1$ \\
\hline BERINJELA & 83 & 30 & 24 & 77 & $-7,2$ \\
\hline CACAU & 61 & 22 & 24 & 63 & 3,3 \\
\hline MELANCIA & 87 & 32 & 24 & 79 & $-9,2$ \\
\hline ABOBBORA & 59 & 24 & 18 & 53 & $-10,2$ \\
\hline MORANGO & 47 & 16 & 18 & 49 & 4,3 \\
\hline ALFACE & 32 & 13 & 17 & 36 & 12,5 \\
\hline OUTRAS & 6 & 2 & 17 & 21 & 250,0 \\
\hline PASTAGEM & 45 & 14 & 17 & 48 & 6,7 \\
\hline ABACAXI & 58 & 20 & 16 & 54 & $-6,9$ \\
\hline BROCOLIS & 49 & 20 & 16 & 45 & $-8,2$ \\
\hline CEVADA & 28 & 10 & 16 & 34 & 21,4 \\
\hline FIGO & 34 & 13 & 16 & 37 & 8,8 \\
\hline MANGA & 30 & 11 & 16 & 35 & 16,7 \\
\hline SORGO & 29 & 6 & 16 & 39 & 34,5 \\
\hline COUVE-FLOR & 51 & 17 & 15 & 49 & $-3,9$ \\
\hline EUCALIPTO & 14 & 1 & 13 & 26 & 85,7 \\
\hline GOIABA & 31 & 11 & 13 & 33 & 6,5 \\
\hline
\end{tabular}


continuação da Tabela 39

\begin{tabular}{|c|c|c|c|c|c|}
\hline $\begin{array}{l}\text { CULTURAPRODUTO DE } \\
\text { DESTINAÇÃO }\end{array}$ & 1990 & SAÍDA & NOVOS & 2000 & $\begin{array}{c}\text { CRESC. } \\
\%\end{array}$ \\
\hline PERA & 65 & 24 & 13 & 54 & $-16,9$ \\
\hline SERINGUEIRA & 52 & 13 & 13 & 52 & 0,0 \\
\hline ABACATE & 32 & 13 & 12 & 31 & $-3,1$ \\
\hline ÁREAS NÃO CULTIVADAS & 25 & 11 & 11 & 25 & 0,0 \\
\hline MARMELO & 25 & 12 & 11 & 24 & $-4,0$ \\
\hline ERVILHA & 38 & 16 & 10 & 32 & $-15,8$ \\
\hline ABOBRINHA & 12 & 5 & 9 & 16 & 33,3 \\
\hline FEIJÄO-VAGEM & 37 & 12 & 9 & 34 & $-8,1$ \\
\hline MAMÄO & 24 & 11 & 9 & 22 & $-8,3$ \\
\hline BETERRABA & 12 & 8 & 8 & 12 & 0,0 \\
\hline PINUS & 9 & 2 & 8 & 15 & 66,7 \\
\hline AMEIXA & 24 & 14 & 6 & 16 & $-33,3$ \\
\hline CAQUI & 19 & 11 & 6 & 14 & $-26,3$ \\
\hline FARINHAS & 0 & 0 & 6 & 6 & - \\
\hline JILO & 22 & 9 & 6 & 19 & $-13,6$ \\
\hline NÉSPERA & 13 & 6 & 6 & 13 & 0,0 \\
\hline CAJU & 11 & 6 & 5 & 10 & $-9,1$ \\
\hline NECTARINA & 7 & 3 & 5 & 9 & 28,6 \\
\hline QUIABO & 26 & 7 & 5 & 24 & $-7,7$ \\
\hline ALFAFA & 25 & 9 & 4 & 20 & $-20,0$ \\
\hline ALMEIRĀO & 9 & 5 & 4 & 8 & $-11,1$ \\
\hline AVEIA & 16 & 6 & 4 & 14 & $-12,5$ \\
\hline CHICÓRIA & 12 & 7 & 4 & 9 & $-25,0$ \\
\hline CÓcO & 9 & 4 & 4 & 9 & 0,0 \\
\hline PIMENTA & 8 & 3 & 4 & 9 & 12,5 \\
\hline AIPO & 8 & 3 & 2 & 7 & $-12,5$ \\
\hline GIRASSOL & 13 & 2 & 2 & 13 & 0,0 \\
\hline MARACUJÁ & 10 & 1 & 2 & 11 & 10,0 \\
\hline MENTA & 2 & 1 & 2 & 3 & 50,0 \\
\hline NABO & 9 & 4 & 2 & 7 & $-22,2$ \\
\hline OLIVEIRA & 4 & 2 & 2 & 4 & 0,0 \\
\hline PECAN & 6 & 2 & 2 & 6 & 0,0 \\
\hline ALGODÁO-ARBÓREO & 1 & 0 & 1 & 2 & 100,0 \\
\hline ALHO-PORRO & 8 & 3 & 1 & 6 & $-25,0$ \\
\hline CEBOLINHA & 3 & 1 & 1 & 3 & 0,0 \\
\hline $\mathrm{CHA}$ & 12 & 4 & 1 & 9 & $-25,0$ \\
\hline ESTUFAS & 2 & 1 & 1 & 2 & 0,0 \\
\hline GRAMADOS & 16 & 5 & 1 & 12 & $-25,0$ \\
\hline GRÃO-DE-BICO & 1 & 0 & 1 & 2 & 100,0 \\
\hline HORTALIÇAS_FOLHOSAS & 2 & 1 & 1 & 2 & 0,0 \\
\hline HORTALIÇAS_NAO_FOLHO & 2 & 1 & 1 & 2 & 0,0 \\
\hline PIMENTA-DO-REINO & 13 & 4 & 1 & 10 & $-23,1$ \\
\hline SISAL & 6 & 0 & 1 & 7 & 16,7 \\
\hline ACELGA & 3 & 0 & 0 & 3 & 0,0 \\
\hline ACCUDES - REPRESAS & 2 & 2 & 0 & 0 & $-100,0$ \\
\hline ALCACHOFRA & 3 & 0 & 0 & 3 & 0,0 \\
\hline ALGODÃO-SEMENTE & 2 & 0 & 0 & 2 & 0,0 \\
\hline AMBIENTES AQUÁTICOS & 1 & 0 & 0 & 1 & 0,0 \\
\hline ANONA & 2 & 1 & 0 & 1 & $-50,0$ \\
\hline ARMAZÉNS - SILOS & 9 & 3 & 0 & 6 & $-33,3$ \\
\hline
\end{tabular}


continuação da Tabela 39

\begin{tabular}{lcccc}
\hline $\begin{array}{l}\text { CULTURAPRODUTO DE } \\
\text { DESTINAÇÃO }\end{array}$ & 1990 & SAÍDA NOVOS & 2000 & $\begin{array}{c}\text { CRESC. } \\
\%\end{array}$ \\
\hline
\end{tabular}

\begin{tabular}{lccccc}
\hline ARROZ-DE-SEQUEIRO & 5 & 1 & 0 & 4 & $-20,0$ \\
\hline ARROZ-IRRIGADO & 12 & 1 & 0 & 11 & $-8,3$ \\
\hline ASPARGO & 6 & 1 & 0 & 5 & $-16,7$ \\
\hline BABAÇU & 1 & 0 & 0 & 1 & 0,0 \\
\hline BATATA-DOCE & 1 & 1 & 0 & 0 & $-100,0$ \\
\hline BATATINHA & 16 & 7 & 0 & 9 & $-43,8$ \\
\hline CENTEIO & 10 & 4 & 0 & 6 & $-40,0$ \\
\hline CEREAIS & 1 & 0 & 0 & 1 & 0,0 \\
\hline CHUCHÚ & 5 & 2 & 0 & 3 & $-40,0$ \\
\hline CRUCIFERAS & 3 & 1 & 0 & 2 & $-33,3$ \\
\hline CUCURBITACEAS & 4 & 2 & 0 & 2 & $-50,0$ \\
\hline CUPINS & 2 & 1 & 0 & 1 & $-50,0$ \\
\hline DAMASCO & 1 & 1 & 0 & 0 & $-100,0$ \\
\hline ESPALHANTE & 21 & 4 & 0 & 17 & $-19,0$ \\
\hline ESPINAFRE & 4 & 1 & 0 & 3 & $-25,0$ \\
\hline ESSEENCIAS-FLORESTAIS & 4 & 2 & 0 & 2 & $-50,0$ \\
\hline FORMIGAS & 19 & 14 & 0 & 5 & $-73,7$ \\
\hline FORRAGEM & 7 & 4 & 0 & 3 & $-57,1$ \\
\hline FRUTA-DO-CONDE & 2 & 1 & 0 & 1 & $-50,0$ \\
\hline FUNGOS-DE-SOLO & 4 & 0 & 0 & 4 & 0,0 \\
\hline GRÁOS-ARMAZENADOS & 11 & 2 & 0 & 9 & $-18,2$ \\
\hline HORTALIÇAS & 3 & 0 & 0 & 3 & 0,0 \\
\hline INSETOS-DE-SOLO & 3 & 0 & 0 & 3 & 0,0 \\
\hline JABOTICABA & 1 & 0 & 0 & 1 & 0,0 \\
\hline LEGUMINOSA & 1 & 0 & 0 & 1 & 0,0 \\
\hline LESMAS_CARAMUJOS_CAR & 1 & 1 & 0 & 0 & $-100,0$ \\
\hline LINHO & 1 & 0 & 0 & 1 & 0,0 \\
\hline MAMONA & 5 & 1 & 0 & 4 & $-20,0$ \\
\hline MANDIOCA & 16 & 3 & 0 & 13 & $-18,8$ \\
\hline MORANGA & 4 & 2 & 0 & 2 & $-50,0$ \\
\hline MOSTARDA & 2 & 1 & 0 & 1 & $-50,0$ \\
\hline NÄO-GRAMINEAS & 1 & 0 & 0 & 1 & 0,0 \\
\hline NEMATOIDES & 4 & 0 & 0 & 4 & 0,0 \\
\hline PRODUTO_CONCENTRADO & 1 & 0 & 0 & 1 & 0,0 \\
\hline RABANETE & 4 & 3 & 0 & 1 & $-75,0$ \\
\hline SALSÄO & 1 & 1 & 0 & 0 & $-100,0$ \\
\hline SERRALHA & 3 & 0 & 0 & 3 & 0,0 \\
\hline VAGEM & 10 & 3 & 0 & 7 & $-30,0$ \\
\hline & & & & & \\
\hline & 1 & 0 & 0 & 0 \\
\hline
\end{tabular}

Fontes: Compêndio ${ }^{4}$, Agrofit $/ 98^{48}$, Agrotis ${ }^{1}$ 
As Tabelas 40, 41 e 42 apresentam os dados referentes aos produtos comerciais registrados após a "Lei dos Agrotóxicos", segundo as culturas/produtos de destinação, mostrando, respectivamente, as suas distribuições segundo a Classe de Uso, a Classe Toxicológica e a Classe de Potencial de Periculosidade Ambiental.

A análise das Classes de Uso dos novos registros (Tabela 40) mostra que são basicamente as mesmas culturas/produtos de destinação que respondem pelo maior número de registros nas diferentes classes. Com relação aos inseticidas, as culturas/produtos de destinação com maior número de registros (ordem decrescente) foram o algodão, as ornamentais, o tomate, os citros, o milho, a soja, o feijão e o café (todas com mais de 40 produtos registrados). Para os fungicidas foram as ornamentais, o tomate, a batata, o feijão, o trigo, a uva, o café, a maçã, os citros e a cebola (todas com mais de 20 produtos registrados). No caso dos herbicidas, a soja, a cana-de-açúcar, o milho, o arroz, o café, os citros e o algodão (todas com mais de 20 produtos registrados). 
Tabela 40 - Distribuição dos Produtos Comerciais registrados posteriormente à "Lei dos Agrotóxicos" (Lei 7802/89), segundo a cultura/produto de destinação e a Classe de Uso.

\begin{tabular}{|c|c|c|c|c|c|}
\hline \multirow{2}{*}{$\begin{array}{l}\text { CULTURAPRODUTO } \\
\text { DE DESTINAÇÃO }\end{array}$} & \multicolumn{5}{|c|}{ CLASSE DE USO * } \\
\hline & Inseticidas & Fungicidas & Herbicidas & Outros & Total \\
\hline ORNAMENTAIS & 72 & 65 & 4 & 4 & 145 \\
\hline SOJA & 56 & 18 & 63 & 6 & 143 \\
\hline ALGODĀO & 94 & 11 & 21 & 8 & 134 \\
\hline TOMATE & 67 & 41 & 4 & 4 & 116 \\
\hline CITROS & 59 & 24 & 23 & 6 & 112 \\
\hline MILHO & 59 & 7 & 38 & 3 & 107 \\
\hline FEIJÃO & 49 & 36 & 12 & 2 & 99 \\
\hline CAFE & 41 & 29 & 24 & 4 & 98 \\
\hline ARROZ & 35 & 11 & 33 & 4 & 83 \\
\hline BATATA & 34 & 38 & 5 & 6 & 83 \\
\hline TRIGO & 34 & 30 & 13 & 2 & 79 \\
\hline CANA-DE-AÇUCAR & 9 & 0 & 45 & 8 & 62 \\
\hline MAÇÄ & 19 & 27 & 11 & 4 & 61 \\
\hline AMENDOIM & 22 & 19 & 5 & 3 & 49 \\
\hline CEBOLA & 14 & 21 & 6 & 5 & 46 \\
\hline UVA & 4 & 30 & 10 & 2 & 46 \\
\hline FUMO & 32 & 4 & 3 & 3 & 42 \\
\hline PEPINO & 11 & 20 & 0 & 0 & 31 \\
\hline ALHO & 7 & 18 & 2 & 3 & 30 \\
\hline BANANA & 4 & 14 & 9 & 3 & 30 \\
\hline REPOLHO & 19 & 4 & 3 & 4 & 30 \\
\hline MELĀO & 12 & 16 & 0 & 0 & 28 \\
\hline PIMENTÃO & 11 & 13 & 1 & 2 & 27 \\
\hline CENOURA & 3 & 17 & 5 & 1 & 26 \\
\hline COUVE & 18 & 5 & 2 & 1 & 26 \\
\hline PÉSSEGO & 8 & 10 & 4 & 4 & 26 \\
\hline BERINJELA & 9 & 11 & 1 & 3 & 24 \\
\hline CACAU & 7 & 11 & 5 & 1 & 24 \\
\hline MELANCIA & 10 & 14 & 0 & 0 & 24 \\
\hline ABÓBORA & 6 & 12 & 0 & 0 & 18 \\
\hline MORANGO & 7 & 10 & 1 & 0 & 18 \\
\hline ALFACE & 5 & 5 & 2 & 5 & 17 \\
\hline OUTRAS & 0 & 4 & 1 & 12 & 17 \\
\hline PASTAGEM & 4 & 0 & 13 & 0 & 17 \\
\hline ABACAXI & 5 & 2 & 6 & 3 & 16 \\
\hline BRÓCOLIS & 9 & 5 & 2 & 0 & 16 \\
\hline CEVADA & 4 & 11 & 1 & 0 & 16 \\
\hline FIGO & 4 & 12 & 0 & 0 & 16 \\
\hline MANGA & 2 & 13 & 0 & 1 & 16 \\
\hline SORGO & 9 & 2 & 5 & 0 & 16 \\
\hline COUVE-FLOR & 9 & 4 & 2 & 0 & 15 \\
\hline EUCALIPTO & 5 & 0 & 8 & 0 & 13 \\
\hline GOIABA & 3 & 9 & 0 & 1 & 13 \\
\hline
\end{tabular}


Continuação da Tabela 40

CULTURAPRODUTO DE DESTINAÇÃO

CLASSE DE USO *

\begin{tabular}{|c|c|c|c|c|c|}
\hline PERA & 5 & 4 & 3 & 1 & 13 \\
\hline SERINGUEIRA & 1 & 4 & 8 & 0 & 13 \\
\hline ABACATE & 3 & 9 & 0 & 0 & 12 \\
\hline ÁREAS NÃO CULTIVADAS & 1 & 0 & 10 & 0 & 11 \\
\hline MARMELO & 4 & 7 & 0 & 0 & 11 \\
\hline ERVILHA & 3 & 7 & 0 & 0 & 10 \\
\hline ABOBRINHA & 4 & 5 & 0 & 0 & 9 \\
\hline FEIJAOO-VAGEM & 3 & 5 & 1 & 0 & 9 \\
\hline MAMÃO & 2 & 6 & 0 & 1 & 9 \\
\hline BETERRABA & 0 & 8 & 0 & 0 & 8 \\
\hline PINUS & 1 & 0 & 7 & 0 & 8 \\
\hline AMEIXA & 0 & 2 & 3 & 1 & 6 \\
\hline CAQUI & 2 & 4 & 0 & 0 & 6 \\
\hline FARINHAS & 6 & 0 & 0 & 0 & 6 \\
\hline JILÓ & 2 & 4 & 0 & 0 & 6 \\
\hline NÉSPERA & 0 & 6 & 0 & 0 & 6 \\
\hline CAJU & 2 & 3 & 0 & 0 & 5 \\
\hline NECTARINA & 0 & 0 & 4 & 1 & 5 \\
\hline QUIABO & 2 & 2 & 1 & 0 & 5 \\
\hline ALFAFA & 2 & 0 & 0 & 2 & 4 \\
\hline ALMEIRĀO & 3 & 1 & 0 & 0 & 4 \\
\hline AVEIA & 0 & 3 & 1 & 0 & 4 \\
\hline CHICÓRIA & 3 & 1 & 0 & 0 & 4 \\
\hline CỐCO & 3 & 1 & 0 & 0 & 4 \\
\hline PIMENTA & 1 & 3 & 0 & 0 & 4 \\
\hline AIPO & 1 & 1 & 0 & 0 & 2 \\
\hline GIRASSOL & 0 & 1 & 1 & 0 & 2 \\
\hline MARACUJÁ & 0 & 2 & 0 & 0 & 2 \\
\hline MENTA & 0 & 0 & 0 & 2 & 2 \\
\hline NABO & 0 & 2 & 0 & 0 & 2 \\
\hline OLIVEIRA & 2 & 0 & 0 & 0 & 2 \\
\hline PECAN & 0 & 2 & 0 & 0 & 2 \\
\hline ALGODÁO-ARBÓREO & 0 & 0 & 1 & 0 & 1 \\
\hline ALHO-PORRÓ & 0 & 1 & 0 & 0 & 1 \\
\hline CEBOLINHA & 0 & 1 & 0 & 0 & 1 \\
\hline $\mathrm{CHÁ}$ & 0 & 0 & 1 & 0 & 1 \\
\hline ESTUFAS & 1 & 0 & 0 & 0 & 1 \\
\hline GRAMADOS & 0 & 1 & 0 & 0 & 1 \\
\hline GRAO DE BICO & 1 & 0 & 0 & 0 & 1 \\
\hline HORTALIÇAS FOLHOSAS & 1 & 0 & 0 & 0 & 1 \\
\hline HORTALIÇAS NÃO FOLHO & 1 & 0 & 0 & 0 & 1 \\
\hline PIMENTA-DO-REINO & 0 & 0 & 1 & 0 & 1 \\
\hline SISAL & 0 & 0 & 1 & 0 & 1 \\
\hline
\end{tabular}

* Classes de Uso

- Inseticidas: inseticidas, acaricidas, formicidas, fumigantes, moluscicidas, nematicidas;

- Fungicidas: fungicidas, antibióticos, bactericidas;

- Herbicidas: herbicidas, dessecantes;

- Outros: adjuvantes, antibrotantes, espalhantes adesivos, estimulantes, feromônios, reguladores de crescimento, surfactantes agrícolas.

Fontes: Agrofit $/ 98^{48}$, Agrotis ${ }^{1}$ 
A Tabela 41 mostra que, de modo geral, a maioria dos produtos registrados foram classificados nas Classes Toxicológicas de menor periculosidade, mas para 9 culturas, a maior parte dos produtos registrados foi classificada nas Classes I e II , que indicam maior periculosidade. São elas: fumo $(61,9 \%)$, algodão $(56,7 \%)$, arroz $(56,6 \%)$, sorgo $(56,3 \%)$, abacaxi $(56,3 \%)$, couve $(53,8 \%)$, couve-flor $(53,3 \%)$, amendoim $(53,1 \%)$ e feijão $(52,5 \%)$. Nas culturas sublinhadas a Classe I superou a Classe II. No caso de 34 outras culturas/produtos de destinação, embora o maior número de produtos registrados tenha ocorrido nas Classes III e IV, a Classe I também sobrepujou ou se igualou à Classe II: ornamentais, tomate, citros, milho, café, trigo, cana-de-açúcar, maçã, uva, pepino, banana, repolho, melão, pimentão, cenoura, pêssego, berinjela, cacau, melancia, abóbora, brócolis, cevada, figo, manga, goiaba, pêra, abacate, beterraba, caqui, farinhas, jiló, caju, almeirão e chicória.

Tabela 41 - Distribuição dos Produtos Comerciais registrados posteriormente à "Lei dos Agrotóxicos" (Lei 7802/89), segundo a cultura/produto de destinação e a Classe Toxicológica.

\begin{tabular}{|c|c|c|c|c|c|}
\hline \multirow{2}{*}{$\begin{array}{l}\text { CULTURAVPRODUTO } \\
\text { DE DESTINAÇÃO }\end{array}$} & \multicolumn{5}{|c|}{ CLASSE TOXICOLÓGICA* } \\
\hline & 1 & II & III & IV & Total \\
\hline ORNAMENTAIS & 32 & 15 & 39 & 59 & 145 \\
\hline SOJA & 31 & 32 & 45 & 35 & 143 \\
\hline ALGODÃO & 43 & 33 & 32 & 26 & 134 \\
\hline TOMATE & 28 & 28 & 31 & 29 & 116 \\
\hline CITROS & 20 & 18 & 23 & 51 & 112 \\
\hline MILHO & 28 & 21 & 32 & 26 & 107 \\
\hline FEIJĀO & 31 & 21 & 31 & 16 & 99 \\
\hline CAFE & 26 & 18 & 19 & 35 & 98 \\
\hline ARROZ & 23 & 24 & 18 & 18 & 83 \\
\hline BATATA & 17 & 18 & 28 & 20 & 83 \\
\hline TRIGO & 20 & 10 & 26 & 23 & 79 \\
\hline CANA-DE-AÇÚCAR & 12 & 9 & 19 & 22 & 62 \\
\hline MAÇÃ & 14 & 8 & 16 & 23 & 61 \\
\hline AMENDOIM & 22 & 4 & 10 & 13 & 49 \\
\hline CEBOLA & 9 & 11 & 14 & 12 & 46 \\
\hline UVA & 8 & 5 & 11 & 22 & 46 \\
\hline FUMO & 16 & 10 & 9 & 7 & 42 \\
\hline PEPINO & 5 & 3 & 9 & 14 & 31 \\
\hline ALHO & 5 & 6 & 7 & 12 & 30 \\
\hline BANANA & 7 & 2 & 11 & 10 & 30 \\
\hline REPOLHO & 9 & 6 & 9 & 6 & 30 \\
\hline MELÃO & 8 & 2 & 6 & 12 & 28 \\
\hline PIMENTÃO & 11 & 2 & 4 & 10 & 27 \\
\hline CENOURA & 7 & 6 & 8 & 5 & 26 \\
\hline
\end{tabular}


continuação da Tabela 41

\section{CULTURAPRODUTO DE DESTINAÇÃO}

\section{CLASSE TOXICOLÓGICA*}

\begin{tabular}{|c|c|c|c|c|c|}
\hline COUVE & 6 & 8 & 6 & 6 & 26 \\
\hline PESSEGO & 5 & 3 & 7 & 11 & 26 \\
\hline BERINJELA & 7 & 4 & 3 & 10 & 24 \\
\hline $\mathrm{CACAU}$ & 7 & - & 5 & 12 & 24 \\
\hline MELANCIA & 9 & 2 & 3 & 10 & 24 \\
\hline ABÓBORA & 2 & 2 & 3 & 11 & 18 \\
\hline MORANGO & 2 & 7 & 4 & 5 & 18 \\
\hline ALFACE & 2 & 3 & 4 & 8 & 17 \\
\hline OUTRAS & 0 & 3 & 5 & 9 & 17 \\
\hline PASTAGEM & 1 & 7 & 1 & 8 & 17 \\
\hline ABACAXI & 5 & 4 & 5 & 2 & 16 \\
\hline BRÓCOLIS & 4 & 4 & 4 & 4 & 16 \\
\hline CEVADA & 3 & 2 & 7 & 4 & 16 \\
\hline $\mathrm{FIGO}$ & 2 & 0 & 4 & 10 & 16 \\
\hline MANGA & 4 & 1 & 3 & 8 & 16 \\
\hline SORGO & 8 & 1 & 6 & 1 & 16 \\
\hline COUVE-FLOR & 4 & 4 & 3 & 4 & 15 \\
\hline EUCALIPTO & 0 & 2 & 3 & 8 & 13 \\
\hline GOIABA & 2 & 0 & 3 & 8 & 13 \\
\hline PERA & 2 & 0 & 2 & 9 & 13 \\
\hline SERINGUEIRA & 0 & 1 & 6 & 6 & 13 \\
\hline ABACATE & 2 & $0-$ & 3 & 7 & 12 \\
\hline ÁREAS NÃO CULTIVADAS & 1 & 2 & 2 & 6 & 11 \\
\hline MARMELO & 1 & 1 & 0 & 9 & 11 \\
\hline ERVILHA & 1 & 0 & 4 & 5 & 10 \\
\hline ABOBRINHA & 1 & 0 & 1 & 7 & 9 \\
\hline FEIJÃO-VAGEM & 1 & 1 & 3 & 4 & 9 \\
\hline MAMAO & 0 & 1 & 1 & 7 & 9 \\
\hline BETERRABA & 1 & 0 & 4 & 3 & 8 \\
\hline PINUS & 0 & 0 & 2 & 6 & 8 \\
\hline AMEIXA & 0 & 0 & 2 & 4 & 6 \\
\hline CAQUI & 2 & 0 & 1 & 3 & 6 \\
\hline FARINHAS & 6 & 0 & 0 & 0 & 6 \\
\hline JILÓ & 1 & 0 & 0 & 5 & 6 \\
\hline NESPERA & 0 & 0 & 0 & 6 & 6 \\
\hline CAJU & 2 & 0 & 1 & 2 & 5 \\
\hline NECTARINA & 0 & 0 & 1 & 4 & 5 \\
\hline QUIABO & 1 & 1 & 0 & 3 & 5 \\
\hline ALFAFA & 0 & 1 & 1 & 2 & 4 \\
\hline ALMEIRAO & 2 & 0 & 0 & 2 & 4 \\
\hline AVEIA & 0 & 1 & 2 & 1 & 4 \\
\hline CHICÓRIA & 2 & 0 & 0 & 2 & 4 \\
\hline $\mathrm{CÓCO}$ & 0 & 1 & 1 & 2 & 4 \\
\hline PIMENTA & 0 & 0 & 0 & 4 & 4 \\
\hline AIPO & 0 & 0 & 1 & 1 & 2 \\
\hline GIRASSOL & 0 & 1 & 1 & 0 & 2 \\
\hline MARACUJÁ & 0 & 0 & 2 & 0 & 2 \\
\hline MENTA & 0 & 0 & 1 & 1 & 2 \\
\hline NABO & 0 & 0 & 0 & 2 & 2 \\
\hline OLIVEIRA & 0 & 0 & 0 & 2 & 2 \\
\hline
\end{tabular}


continuação da Tabela 41

\begin{tabular}{|c|c|c|c|c|c|}
\hline \multirow{2}{*}{$\begin{array}{l}\text { CULTURAVRODUTO } \\
\text { DE DESTINAÇÃOO }\end{array}$} & \multicolumn{5}{|c|}{ CLASSE TOXICOLÓGICA* } \\
\hline & I & II & III & IV & Total \\
\hline PECAN & 0 & 0 & 0 & 2 & 2 \\
\hline ALGODÄO-ARBÓREO & 0 & 1 & 0 & 0 & 1 \\
\hline ALHO-PORRÓ & 0 & 0 & 0 & 1 & 1 \\
\hline CEBOLINHA & 0 & 0 & 0 & 1 & 1 \\
\hline $\mathrm{CHA}$ & 0 & 1 & 0 & 0 & 1 \\
\hline ESTUFAS & 0 & 0 & 1 & 0 & 1 \\
\hline GRAMADOS & 0 & 0 & 1 & 0 & 1 \\
\hline GRAO DE BICO & 0 & 0 & 1 & 0 & 1 \\
\hline HORTALICCAS FOLHOSAS & 0 & 0 & 1 & 0 & 1 \\
\hline HORTALIÇAS NĀO FOLH & 0 & 0 & 1 & 0 & 1 \\
\hline PIMENTA-DO-REINO & 0 & 0 & 1 & 0 & 1 \\
\hline SISAL & 0 & 0 & 1 & 0 & 1 \\
\hline
\end{tabular}

\footnotetext{
Classes Toxicológicas: I - extremamente tóxico; II - altamente tóxico;

Fontes: Ministério da Saúde, Agrofit $/ 98^{48}$, Agrotis ${ }^{1}$

A Tabela 42, a respeito da classificação ambiental dos produtos comerciais, mostra que para 42 culturas/produtos de destinação não foi possível obter a Classificação de Potencial de Periculosidade Ambiental referente a 50\% ou mais dos produtos registrados. Das 76 culturas/produtos de destinação em que foi possível identificar ao menos um produto registrado com classificação ambiental, 37 tinham $50 \%$ ou mais dos produtos registrados classificados nas Classes I e II, de maior periculosidade: algodão, alho, ameixa, amendoim, áreas não cultivadas, arroz, aveia, banana, batata, berinjela, cacau, café, cana-de-açúcar, cebola, cenoura, cevada, citros, couve, ervilha, farinhas, feijão, fumo, girassol, maçã, maracujá, melancia, milho morango, nectarina, ornamentais, pastagem, pinus, soja, sorgo, tomate, trigo e uva. 
Tabela 42 - Distribuição dos Produtos Comerciais registrados posteriormente à "Lei dos Agrotóxicos" (Lei 7802/89), segundo a cultura/produto de destinação e a Classe de Potencial de Periculosidade Ambiental.

\begin{tabular}{|c|c|c|c|c|c|c|}
\hline \multirow{2}{*}{$\begin{array}{l}\text { CULTURAPRODUTO } \\
\text { DE DESTINAÇÃO }\end{array}$} & \multirow{2}{*}{$\frac{\text { CLASSE }}{\mathrm{I}}$} & \multicolumn{5}{|c|}{ POTENCIAL DE PERICULOSIDADE AMBIENTAL* } \\
\hline & & II & III & IV & s/ inf. & Total \\
\hline ORNAMENTAIS & 7 & 42 & 33 & 1 & 62 & 145 \\
\hline SOJA & 16 & 48 & 40 & 9 & 30 & 143 \\
\hline ALGODĀO & 13 & 51 & 25 & 4 & 41 & 134 \\
\hline TOMATE & 9 & 41 & 29 & 5 & 32 & 116 \\
\hline CITROS & 8 & 38 & 25 & 15 & 26 & 112 \\
\hline MILHO & 13 & 43 & 18 & 2 & 31 & 107 \\
\hline FEIJÃO & 9 & 38 & 21 & 3 & 28 & 99 \\
\hline CAFE & 8 & 30 & 20 & 4 & 36 & 98 \\
\hline ARROZ & 10 & 26 & 18 & 3 & 26 & 83 \\
\hline BATATA & 6 & 34 & 20 & 2 & 21 & 83 \\
\hline TRIGO & 7 & 24 & 19 & 4 & 25 & 79 \\
\hline CANA-DE-AÇÚCAR & 1 & 31 & 17 & 2 & 11 & 62 \\
\hline$\overline{M A C ̧ A ̄ ~}$ & 7 & 22 & 13 & 4 & 15 & 61 \\
\hline AMENDOIM & 5 & 12 & 10 & 3 & 19 & 49 \\
\hline CEBOLA & 3 & 17 & 10 & 2 & 14 & 46 \\
\hline UVA & 0 & 18 & 14 & 2 & 12 & 46 \\
\hline FUMO & 6 & 6 & 4 & 6 & 20 & 42 \\
\hline PEPINO & 0 & 8 & 11 & 4 & 8 & 31 \\
\hline$\overline{A L H O}$ & 2 & 7 & 7 & 1 & 13 & 30 \\
\hline BANANA & 1 & 11 & 7 & 1 & 10 & 30 \\
\hline REPOLHO & 0 & 5 & 5 & 4 & 16 & 30 \\
\hline MELÁO & 0 & 8 & 9 & 2 & 9 & 28 \\
\hline PIMENTĀO & 0 & 5 & 5 & 2 & 15 & 27 \\
\hline$\overline{\text { CENOURA }}$ & 2 & 12 & 6 & 0 & 6 & 26 \\
\hline COUVE & 3 & 5 & 4 & 2 & 12 & 26 \\
\hline PESSEGO & 1 & 6 & 5 & 4 & 10 & 26 \\
\hline BERINJELA & 1 & 5 & 4 & 2 & 12 & 24 \\
\hline CACAU & 2 & 3 & 5 & 0 & 14 & 24 \\
\hline MELANCIA & 0 & 9 & 6 & 2 & 7 & 24 \\
\hline$\overline{A B O ́ B O R A}$ & 0 & 2 & 5 & 4 & 7 & 18 \\
\hline MORANGO & 3 & 6 & 4 & 1 & 4 & 18 \\
\hline$\overline{A L F A C E}$ & 1 & 3 & 4 & 1 & 8 & 17 \\
\hline OUTRAS & 0 & 0 & 5 & 7 & 5 & 17 \\
\hline PASTAGEM & 0 & 8 & 3 & 1 & 5 & 17 \\
\hline ABACAXI & 1 & 2 & 4 & 0 & 9 & 16 \\
\hline BRÓCOLIS & 0 & 1 & 3 & 2 & 10 & 16 \\
\hline CEVADA & 1 & 8 & 2 & 1 & 4 & 16 \\
\hline FIGO & 0 & 1 & 5 & 1 & 9 & 16 \\
\hline MANGA & 0 & 4 & 3 & 2 & 7 & 16 \\
\hline SORGO & 1 & 5 & 1 & 0 & 9 & 16 \\
\hline COUVE-FLOR & 0 & 1 & 3 & 1 & 10 & 15 \\
\hline
\end{tabular}


Continuação da Tabela 42

\begin{tabular}{|c|c|c|c|c|c|c|}
\hline CULTURAPRODUTO & CLASSE & POTEN & $\mathbf{D E}$ & ULO & DE AM & ENTAL* \\
\hline DE DESTINAÇÃO & 1 & II & III & IV & s/ inf. & Total \\
\hline EUCALIPTO & 0 & 3 & 3 & 2 & 5 & 13 \\
\hline GOIABA & 0 & 1 & 4 & 1 & 7 & 13 \\
\hline PERA & 0 & 2 & 2 & 1 & 8 & 13 \\
\hline SERINGUEIRA & 0 & 1 & 5 & 1 & 6 & 13 \\
\hline ABACATE & 0 & 0 & 4 & 0 & 8 & 12 \\
\hline ÁREAS NÃO CULTIVADAS & 0 & 4 & 4 & 0 & 3 & 11 \\
\hline MARMELO & 1 & 0 & 3 & 2 & 5 & 11 \\
\hline ERVILHA & 3 & 0 & 1 & 1 & 5 & 10 \\
\hline ABOBRINHA & 0 & 1 & 2 & 4 & 2 & 9 \\
\hline FEIJÃO-VAGEM & 0 & 0 & 2 & 1 & 6 & 9 \\
\hline MAMÃO & 1 & 0 & 2 & 3 & 3 & 9 \\
\hline BETERRABA & 0 & 2 & 3 & 0 & 3 & 8 \\
\hline PINUS & 0 & 3 & 3 & 0 & 2 & 8 \\
\hline AMEIXA & 0 & 2 & 1 & 0 & 3 & 6 \\
\hline CAQUI & 0 & 0 & 1 & 0 & 5 & 6 \\
\hline FARINHAS & 1 & 0 & 0 & 0 & 5 & 6 \\
\hline JILÓ & 0 & 1 & 2 & 0 & 3 & 6 \\
\hline NÊSPERA & 0 & 0 & 3 & 0 & 3 & 6 \\
\hline CAJU & 0 & 0 & 1 & 0 & 4 & 5 \\
\hline NECTARINA & 0 & 2 & 2 & 0 & 1 & 5 \\
\hline QUIABO & 0 & 1 & 1 & 1 & 2 & 5 \\
\hline ALFAFA & 0 & 0 & 0 & 2 & 2 & 4 \\
\hline ALMEIRÃO & 0 & 0 & 1 & 0 & 3 & 4 \\
\hline AVEIA & 1 & 1 & 1 & 0 & 1 & 4 \\
\hline CHICÓRIA & 0 & 0 & 1 & 0 & 3 & 4 \\
\hline Côco & 0 & 1 & 0 & 2 & 1 & 4 \\
\hline PIMENTA & 0 & 0 & 0 & 1 & 3 & 4 \\
\hline AIPO & 0 & 0 & 1 & 0 & 1 & 2 \\
\hline GIRASSOL & 0 & 1 & 0 & 0 & 1 & 2 \\
\hline MARACUJÁ & 0 & 2 & 0 & 0 & 0 & 2 \\
\hline MENTA & 0 & 0 & 0 & 1 & 1 & 2 \\
\hline NABO & 0 & 0 & 1 & 0 & 1 & 2 \\
\hline OLIVEIRA & 0 & 0 & 1 & 0 & 1 & 2 \\
\hline PECAN & 0 & 0 & 1 & 0 & 1 & 2 \\
\hline ALGODÃO-ARBÓREO & 0 & 0 & 0 & 0 & 1 & 1 \\
\hline ALHO-PORRÓ & 0 & 0 & 0 & 0 & 1 & 1 \\
\hline CEBOLINHA & 0 & 0 & 0 & 0 & 1 & 1 \\
\hline CHÁ & 0 & 0 & 0 & 0 & 1 & 1 \\
\hline ESTUFAS & 0 & 0 & 0 & 0 & 1 & 1 \\
\hline GRAMADOS & 0 & 0 & 0 & 0 & 1 & 1 \\
\hline GRAO DE BICO & 0 & 0 & 1 & 0 & 0 & 1 \\
\hline HORTALIÇAS FOLHOSAS & 0 & 0 & 0 & 0 & 1 & 1 \\
\hline HORTALIÇAS NÃO FOLHO & 0 & 0 & 0 & 0 & 1 & 1 \\
\hline PIMENTA-DO-REINO & 0 & 0 & 0 & 0 & 1 & 1 \\
\hline SISAL & 0 & 0 & 0 & 0 & 1 & 1 \\
\hline
\end{tabular}

* Classes de Potencial de Periculosidade Ambiental: I - Produto Altamente Perigoso; II - Produto Muito Perigoso; III - Produto Perigoso; IV-Produto Pouco Perigoso Fontes: IBAMA, Agrofit $/ 98^{48}$, Agrotis ${ }^{1}$ 


\section{Objetivo específico $n^{0} 6$}

\section{Pulgão do Algodoeiro (Aphis gossypii)}

As Tabelas 43, 44 e 45 apresentam os dados referentes aos produtos comerciais registrados para o controle do "pulgão do algodoeiro".

A Tabela 43 mostra que em 1990 havia 77 produtos comerciais registrados para o controle do pulgão, com $84,4 \%$ deles classificados nas Classes I e II, de maior periculosidade ( $53,2 \%$ na Classe I). Os demais $15,6 \%$ se encontravam na Classe III. Não havia produtos de Classe IV registrados. Há a indicação de que 18 produtos deixaram de ser registrados para essa finalidade até o ano de 2000, implicando em uma diminuição de $25 \%$ de produtos na Classe III e 25\% na Classe II. Para a Classe I essa diminuição foi de $22 \%$ no período.

Tabela 43 - Distribuição dos Produtos Comerciais que estavam registrados para o controle do "pulgão do algodoeiro" (Aphis gossypii) em 1990 e dos produtos que deixaram de ser registrados para essa finalidade após essa data e até 2000, segundo a Classe Toxicológica.

\begin{tabular}{|c|c|c|c|c|c|}
\hline \multirow{2}{*}{$\begin{array}{c}\text { CLASSE } \\
\text { TOXICOLÓGICA* }\end{array}$} & \multicolumn{2}{|c|}{1990} & \multicolumn{2}{|c|}{$\begin{array}{c}\text { SAÍDA até } \\
2000\end{array}$} & \multirow{2}{*}{$\begin{array}{c}\% \text { DE } \\
\text { PRODUTOS } \\
\text { QUE } \\
\text { SAÍRAM }\end{array}$} \\
\hline & № & $\%$ & № & $\%$ & \\
\hline I & 41 & 53,2 & 9 & 50,0 & 22,0 \\
\hline II & 24 & 31,2 & 6 & 33,3 & 25,0 \\
\hline III & 12 & 15,6 & 3 & 16,7 & 25,0 \\
\hline IV & - & - & - & - & - \\
\hline TOTAL & 77 & 100,0 & 18 & 100,0 & - \\
\hline
\end{tabular}

Classes Toxicológicas (Port. 4/80):

I - altamente tóxico; II - medianamente tóxico;

III - pouco tóxico; IV - praticamente não tóxico

Fontes: Compêndio ${ }^{4}$, Agrofit $/ 98^{48}$, Agrotis ${ }^{1}$ 
Como pode ser observado na Tabela 44, além dos 59 produtos comerciais que permaneceram registrados no período após a Lei para o controle do "pulgão do algodoeiro", foram acrescentados mais 40 novos produtos para a mesma finalidade, no período de referência, a maior parte na Classe I $(40,0 \%)$, seguida de forma decrescente pela Classe II (32,5\%), Classe III (20,0\%) e Classe IV (7,5\%). Estatisticamente, não há diferença significativa entre a distribuição da classificação toxicológica dos produtos que permaneceram registrados e a dos novos produtos $(Z=-0,5509$ e $\mathrm{p}<0,5817)$. Tampouco há diferença significativa entre a distribuição da classificação toxicológica dos produtos que permaneceram registrados e a do total constante em $2000(Z=-0,2805$ e $p=0,7791)$.

Tabela 44 - Distribuição dos Produtos Comerciais que
permaneceram registrados após a "Lei dos Agrotóxicos" (Lei
7802/89) para o controle do "pulgão do algodoeiro" (Aphis gossypii),
dos novos* produtos e do total que estava registrado em 2000,
segundo a Classe Toxicológica.

\begin{tabular}{|c|c|c|c|c|c|c|}
\hline \multirow[t]{2}{*}{$\begin{array}{c}\text { CLASSE } \\
\text { TOXICOLÓGICA }{ }^{\star *}\end{array}$} & \multicolumn{2}{|c|}{$\begin{array}{c}\text { Permaneceram } \\
\text { registrados } \\
\text { (reclassificados) }\end{array}$} & \multicolumn{2}{|c|}{ Novos* } & \multicolumn{2}{|c|}{$\begin{array}{l}\text { Total } \\
2000\end{array}$} \\
\hline & № & $\%$ & № & $\%$ & № & $\%$ \\
\hline I & 25 & 42,4 & 16 & 40,0 & 41 & 41,4 \\
\hline II & 21 & 35,6 & 13 & 32,5 & 34 & 34,3 \\
\hline III & 10 & 16,9 & 8 & 20,0 & 18 & 18,2 \\
\hline IV & 3 & 5,1 & 3 & 7,5 & 6 & 6,1 \\
\hline TOTAL & 59 & 100,0 & 40 & 100,0 & 99 & 100,0 \\
\hline
\end{tabular}

* novos: Produtos Comerciais registrados após a Lei

** Classes Toxicológicas (Portaria 3/92):

I - extremamente tóxico; II - altamente tóxico;

III - medianamente tóxico; IV - pouco tóxico

Fontes: Ministério da Saúde, Agrofit $/ 98^{48}$, Agrotis ${ }^{1}$ 
Pela Tabela 45 podemos observar que $26(65 \%)$ dos 40 novos produtos comerciais registrados para o controle do pulgão do algodoeiro são derivados de ingredientes ativos que já eram registrados antes da "Lei dos Agrotóxicos" e são proporcionalmente classificados em maior número $(84,6 \%)$ nas Classes I e II, de maior periculosidade. No entanto, embora a comparação das distribuições dos produtos segundo a Classe Toxicológica seja significativamente diferente entre os derivados de ingredientes ativos "antigos" e "novos" $(Z=-2,6943$ e $p<0,0071)$, os derivados destes "novos" ingredientes ativos, registrados no periodo após a Lei, também contam com grande proporção (50\%) de produtos comerciais nessas mesmas classes.

Tabela 45 - Distribuição dos Produtos Comerciais registrados após a "Lei dos Agrotóxicos" (Lei 7802/89), para o controle do "pulgão do algodoeiro" (Aphis gossypii), segundo a Classe Toxicológica e a época de registro do Ingrediente Ativo.

\begin{tabular}{|c|c|c|c|c|}
\hline \multirow[t]{2}{*}{ CLASSE TOXICOLÓGICA* } & \multicolumn{2}{|c|}{$\begin{array}{l}\text { IA registrado } \\
\text { antes da Lei }\end{array}$} & \multicolumn{2}{|c|}{$\begin{array}{l}\text { IA registrado } \\
\text { após a Lei }\end{array}$} \\
\hline & № & $\%$ & № & $\%$ \\
\hline I & 13 & 50,0 & 3 & 21,4 \\
\hline II & 9 & 34,6 & 4 & 28,6 \\
\hline III & 4 & 15,4 & 4 & 28,6 \\
\hline IV & - & - & 3 & 21,4 \\
\hline TOTAL & 26 & 100,0 & 14 & 100,0 \\
\hline
\end{tabular}

* Classes Toxicológicas (Portaria 3/92):

$$
\begin{aligned}
& \text { I - extremamente tóxico; II - altamente tóxico; } \\
& \text { III - medianamente tóxico; IV - pouco tóxico }
\end{aligned}
$$

Fontes: Ministério da Saúde, Agrofit $/ 98^{48}$, Agrotis $^{1}$ 
Hipóteses

A análise das hipóteses propostas se apresentou como segue:

Hipótese 1 - considerando que apesar do aumento das exigências toxicológicas foi observado aumento das ocorrências de intoxicações agudas no período estudado, a hipótese foi aceita.

Hipótese 2 - considerando que as alterações ocorridas nos critérios de classificação toxicológica podem ter proporcionado mudanças de Classes Toxicológicas de maior risco para classes de menor risco na maioria dos produtos que estavam registrados, implicando mudanças na comunicação de riscos utilizada nos rótulos que podem ter possibilitado o agravamento dos impactos à saúde provocados pelo uso de agrotóxicos, a hipótese foi aceita.

Hipótese $n^{0} 3$ - considerando que não foram encontradas diferenças significativas entre a distribuição, segundo a Classe Toxicológica, dos ingredientes ativos registrados sob a antiga legislação e a dos que se encontram registrados sob a nova legislação, a hipótese foi rejeitada.

Hipótese $n^{0} 4$ - considerando que não foram encontradas diferenças significativas entre a distribuição, segundo a Classe Toxicológica, dos ingredientes ativos registrados sob a antiga legislação e a dos que se encontram registrados sob a nova legislação, nas diferentes Classes de Uso (inseticidas, fungicidas e herbicidas), a hipótese foi rejeitada.

Hipótese $\mathbf{n}^{0} 5$ - considerando que na classe dos inseticidas foi observada diferença significativa entre a distribuição, segundo a Classe Toxicológica, dos ingredientes ativos registrados sob a antiga legislação e a dos que 
foram registrados sob a nova legislação, apontando para um maior aumento relativo de registros de ingredientes ativos de menor toxicidade aguda, a hipótese foi rejeitada.

Hipótese $n^{0} 6$ - considerando que o registro de produtos comerciais derivados dos ingredientes ativos que já estavam registrados antes da "Lei dos Agrotóxicos" sobrepujou o registro de produtos derivados dos "novos" ingredientes ativos, registrados no período após a Lei, a hipótese foi aceita.

Hipótese $\mathbf{n}^{0} 7$ - considerando que as culturas que já eram grandes consumidoras de agrotóxicos foram, de modo geral, as que tiveram maior número de registros, a hipótese foi aceita.

Hipótese $\mathrm{n}^{\circ} \mathbf{8}$ - considerando que foram constatados registros de produtos comerciais com classificação toxicológica de maior periculosidade que outros já registrados para a mesma finalidade, a hipótese foi aceita. 


\section{DISCUSSÃO}

Os aspectos relacionados ao controle dos agrotóxicos são diversos e envolvem questões políticas, sociais, econômicas e técnicas. A legislação é apenas um dos fatores essenciais para o controle dessas substâncias e geralmente reflete a evolução dessas questões na sociedade. A implementação da legislação, por sua vez, permite identificar a viabilidade prática e as necessidades técnicas e administrativas para que sua aplicação ocorra de forma eficaz e traz como conseqüência a necessidade de constantes revisões e complementações dos instrumentos legais. Nesse sentido, a "Lei dos Agrotóxicos" se encontra em um constante processo de implantação e vem passando por modificações e complementações, com a edição de novas portarias e decretos de regulamentação.

Mas entre os aspectos que já foram regulamentados, a legislação estabeleceu mecanismos que deveriam favorecer o registro de produtos de menor impacto à saúde e ao ambiente. No entanto, após dez anos da promulgação da Lei, os parâmetros analisados neste trabalho não refletiram a eficácia esperada.

No que se refere aos aspectos de saúde, apenas indicadores de toxicidade aguda foram analisados. Esta limitação ocorreu pela quase indisponibilidade de informações sobre outros tipos de agravos à saúde decorrentes da exposição aos agrotóxicos. Também é preciso considerar que o universo de fatores que interfere nas intoxicações é grande e poderia ser estudado sob vários enfoques (epidemiológico, toxicológico, vigilância à saúde, segurança no trabalho, previdenciário, econômico etc.), mas este estudo buscou apenas analisar a correlação entre vendas de agrotóxicos e ocorrências de intoxicações agudas e a evolução do registro de agrotóxicos com relação à periculosidade à saúde e ao ambiente das substâncias e produtos comerciais registrados, neste aspecto empregando como indicadores os dados de classificação toxicológica e ambiental disponíveis.

Era de se esperar que a aplicação da Lei resultasse em uma diminuição dos casos de intoxicações agudas. Entretanto, os dados analisados apontam para o 
inverso: houve um crescimento quase contínuo de casos que acompanhou diretamente a expansão do mercado desses insumos no período imediatamente anterior e posterior à Lei, no caso, de 1985 a 1999.

A similaridade das curvas de crescimento dos registros de intoxicações e das vendas de agrotóxicos e a relação direta entre eles são, no mínimo, preocupantes. É evidente que é preciso considerar que os números de registro de intoxicações pelo SINITOX utilizados no estudo não são coeficientes, que, se pudessem ser calculados, dariam maior confiabilidade aos dados e à curva da série histórica analisada. Afinal, o aumento seqüencial de casos poderia estar refletindo, por exemplo, o crescimento e melhoria do sistema de registros e não necessariamente o aumento de casos.

Mas desconsiderar que deve haver, de fato, uma relação direta entre vendas e intoxicações seria um raciocinio reducionista, na medida em que o crescimento nos valores de vendas têm significado maiores quantidades de ingredientes ativos e de produtos comercializados ${ }^{2}$, provavelmente implicando em trabalhadores mais expostos ou maior número de trabalhadores expostos, podendo, portanto, levar a um maior número de intoxicações, principalmente quando se fala em países em desenvolvimento $^{26,38}$. Um estudo sobre uso de agrotóxicos e impactos à saúde conduzido pelo World Resources Institute, realizado nas Filipinas, concluiu que os gastos com saúde (medicamentos, consultas etc.) dos agricultores expostos aos agrotóxicos aumentam $0,74 \%$ para cada $1 \%$ de aumento na quantidade utilizada de agrotóxico $^{64}$.

O crescimento paralelo das vendas e intoxicações indica ainda que é preciso se conhecer o que está sendo vendido, porque essa relação direta aponta para um provável aumento de vendas de produtos de maior toxicidade. O que, segundo apurado neste trabalho, é bastante provável, pois, conforme discutido adiante, produtos de maior toxicidade aguda não só permaneceram registrados como continuaram a ser registrados após a Lei.

Outro dado que pode reforçar a relação direta entre vendas e intoxicações é a queda no valor de vendas de agrotóxicos em 1999 e a queda no número de 
intoxicações registradas no mesmo ano. Segundo o Instituto de Economia Agrícola ${ }^{\mathbf{2 0}}$, essa queda nas vendas foi decorrente da menor utilização de agrotóxicos em culturas como cana-de-açúcar, citros, soja, fumo, batata, arroz irrigado, feijão e tomate, devido a fatores como o aumento nos preços desses insumos provocado por desvalorização cambial, queda nos preços de commodities e fatores climáticos que prejudicaram as lavouras em algumas regiões e dificultaram a evolução de doenças em alguns cultivos pelo clima frio e seco, reduzindo o uso de agrotóxicos. Essa diminuição no uso pode ter sido uma causa direta da redução no registro de casos de intoxicações.

Outro fator importante a ser considerado com relação às ocorrências de intoxicações no país e o seu registro é o problema da subnotificação. É preciso considerar que algumas limitações do SINITOX, reconhecidas pelo próprio Sistema ${ }^{8}$, como a irregularidade no envio de dados pelas unidades participantes, a localização da maioria dos Centros nas capitais e o número insuficiente deles para cobrir todo o país, apontam para esse fator. No estado da Califórnia, nos EUA, que possui um bom sistema de registro de ocorrência de intoxicações, estima-se que somente 1 a $2 \%$ dos casos de intoxicações agudas ocorridos com agricultores sejam notificados ${ }^{18}$. Assim, em uma estimativa bastante conservadora, considerando que a cada bilhão de dólares vendidos poderiam ser registrados de 2042 a 2678 casos de intoxicação, poderia ser estimado que ocorreriam, de fato, entre 102.100 e 133.900 casos, ou seja, ao menos uma intoxicação a cada US\$10,000.00 de agrotóxicos vendidos.

Entretanto, mais do que servir para calcular possíveis números de casos de intoxicações, essas estimativas indicam que é preciso investir em mecanismos mais efetivos de controle de riscos relacionados aos agrotóxicos. Em especial aqueles que possibilitem um maior controle dos produtos de maior periculosidade, como preconizado pelas agências internacionais que têm interface com essa questão (OIT, OMS e FAO) e conforme amplamente discutido em trabalho anterior ${ }^{26}$. Essas medidas incluem: restrições de ordem técnica e administrativa para a indicação, a comercialização e o uso; taxações e controle de preços; entre outras. 
A classificação toxicológica e a classificação de periculosidade ambiental são bons instrumentos para essa finalidade, pois possibilitariam definir medidas de controle em diversos níveis: na indicação do produto, na comercialização e no uso. Classificar os produtos segundo a periculosidade dos mesmos possibilita uma rotulagem adequada, com informações necessárias para alertar o usuário sobre os riscos na sua utilização e os meios para controlá-los, e também permite a restrição da comercialização e do uso dos mais perigosos. No entanto, a alternativa da restrição com base nessas classificações não vem sendo adotada.

Antes da "Lei dos Agrotóxicos" os critérios de classificação toxicológica empregados no Brasil estabeleciam faixas de maior amplitude para definir as classes de maior periculosidade à saúde, deixando-as com maior abrangência que as definidas pelos critérios da OMS. Mas, em 1992, o Ministério da Saúde modificou as faixas, talvez para equipará-las às da OMS. Assim, a Portaria $\mathrm{n}^{\mathbf{0}} 3 / 92$, conforme mostrou este estudo, deve ter provocado a reclassificação toxicológica, para classes identificadas como de menor periculosidade, da maioria dos produtos comerciais registrados. O maior impacto dessa medida deve ter se dado com as formulações líquidas, que, além de ser a forma de apresentação da maior parte dos produtos, de modo geral, por suas características de uso e capacidade de exposição, auferem maior risco ao trabalhador. No caso das formulações sólidas, produtos classificados na Classe I podem ter sido deslocados não apenas para a faixa seguinte (Classe II), mas também para a faixa subseqüente (Classe III).

Se o objetivo do legislador foi apenas o de fazer com que o critério de classificação toxicológica adotado pelo Brasil fosse equivalente ao da OMS, ele ignorou que a classificação da Organização é somente uma recomendação e negligenciou a finalidade de classificar, qual seja, distinguir entre os mais e menos perigosos visando estabelecer medidas de controle e alertar os usuários quanto ao perigo no uso daquele produto. $\mathrm{Na}$ prática, a medida criou confusão: o principal problema foi a mudança das cores de sinalização das faixas de advertência dos rótulos dos produtos que já estavam registrados. 
Talvez um impacto imediato mais ameno pudesse ter ocorrido se o legislador não tivesse alterado as denominações e respectivas cores já consolidadas da classificação, adotando apenas uma faixa adicional com uma nova cor específica para a Classe Toxicológica intitulada "extremamente tóxico" e estabelecendo, assim, uma classificação toxicológica com cinco faixas. Dessa forma, seguindo uma tendência contrária ao que ocorreu, haveria o reenquadramento de alguns produtos da classe "altamente tóxico" na classe adicional sugerida, intitulada "extremamente tóxico", de maior periculosidade à saúde. Além disso, considerando as faixas de classificação que foram adotadas, teriam ocorrido apenas alguns deslocamentos de produtos de formulações sólidas da Classe I (altamente tóxico) para a Classe II (medianamente tóxico). Assim, a maioria dos produtos poderia ter sido mantida nas mesmas classes anteriores, com as mesmas denominações e as mesmas cores nas faixas de advertência.

De qualquer forma, porém, a menor "rigidez" provocada pelas mudanças não se justifica, pois pode ter prejudicado o entendimento das faixas de advertência pelos usuários e reduziu a capacidade de se empregar o critério da classificação como um meio mais abrangente de controle de riscos, como a restrição de comercialização ou do uso dos produtos mais perigosos, como recomenda a própria $\mathrm{OMS}^{80}$. Restrições essas que, independente das mudanças, poderiam ser adotadas não só em nível federal, mas também nos âmbitos estaduais e municipais.

Com relação ao comportamento do registro de ingredientes ativos, embora tenham ocorrido crescimentos diferenciados no número de registros nas diferentes Classes de Uso, a proporção de registros entre as classes de inseticidas, herbicidas, fungicidas e "outros" não foi significativamente alterada após a promulgação da "Lei dos Agrotóxicos". A classe dos inseticidas, mesmo com o menor crescimento relativo, se manteve com o maior número de registros, seguida pelos herbicidas, fungicidas e "outros".

Os dados analisados indicam, ainda, que a aplicação da Lei também não gerou diferenças importantes em relação às proporções de substâncias classificadas nas diferentes classes de periculosidade à saúde propostas pela OMS, quando 
considerados os conjuntos de ingredientes ativos que estavam registrados em $1990 \mathrm{e}$ em 2000, mesmo quando as Classes de Uso (inseticidas, fungicidas e herbicidas) são analisadas separadamente.

Já quando comparado o conjunto de substâncias que estava registrado anteriormente à lei (1990) apenas com o conjunto registrado posteriormente à lei ("novas") pôde ser identificada uma certa melhoria, com um perfil de distribuição mais favorável às classes de menor periculosidade à saúde. Mas quando analisadas as Classes de Uso separadamente, isto ocorre apenas com os inseticidas, diferentemente das demais classes e ao contrário do esperado por este estudo. Neste caso, indicando uma tendência que, se consolidada, propiciaria grandes beneficios, pois trata-se da Classe de Uso que mais provoca intoxicações agudas ${ }^{26,31}$.

No entanto alguns fatores podem estar prejudicando este possivel beneficio: é importante observar que, embora o conjunto de novos ingredientes ativos de inseticidas registrados no período após a Lei tenha apresentado um maior número proporcional de registros de menor periculosidade à saúde, foi a única Classe de Uso para a qual foi possível identificar registros de substâncias classificadas pela OMS nas Classes Ia e Ib, de maior periculosidade. Pela classificação toxicológica do Ministério da Saúde, também foi a classe dos inseticidas que apresentou maior proporção de registros de ingredientes ativos nas Classes I e II (somadas), de maior periculosidade. Essa continuidade de registros de substâncias nas classes de maior periculosidade e, especialmente, a permanência do registro das substâncias "antigas", determinam ao conjunto de substâncias que estava registrado em 2000 um perfil de classificação de periculosidade à saúde ainda bastante semelhante ao que existia anteriormente à lei.

Foi observado que $41,5 \%$ dos ingredientes ativos registrados no período posterior à lei não constavam da classificação de periculosidade à saúde da OMS. Este fato apenas indica que, até a edição de 1998-99, essas substâncias ainda não haviam sido incluídas pela Organização na relação de substâncias do guia de classificação da entidade ${ }^{82}$, que é periodicamente revisado e ampliado. Mas um aspecto que chama a atenção nos resultados apurados, em relação às substâncias para 
as quais foi possivel obter a classificação de periculosidade da Organização Mundial da Saúde e a do Ministério da Saúde, é a baixa concordância encontrada entre as duas classificações, considerando o conjunto das substâncias que se encontravam registradas em 2000 ("antigas" + "novas"), e a total discordância estatística entre elas quando considerado apenas o subconjunto dos "novos" ingredientes ativos (registrados no período após a Lei). Essa diferença não era esperada pois, desde 1992 (Portaria $\left.n^{\circ} 3 / 92\right)^{54}$, os parâmetros básicos de classificação das duas entidades, baseados na $\mathrm{DL}_{50}$, são iguais.

Os resultados encontrados indicam que o Ministério da Saúde tende a classificar mais substâncias em classes de maior periculosidade à saúde do que a OMS. Como o critério de classificação do Ministério da Saúde leva em consideração outros fatores além da $\mathrm{DL}_{50}$ (Tabela 5, pg. 19), isto talvez pudesse explicar essa maior freqüência nas classes de maior periculosidade. No entanto, também é possível que parte da informação disponível sobre a classificação toxicológica dos ingredientes ativos, que se encontra nas monografias técnicas das substâncias registradas, publicadas pelo Ministério da Saúde, ainda não tivesse sido atualizada com relação à Portaria $n^{0} 3 / 92^{54}$ quando foi consultada, em julho de 2000. Para averiguar estas possibilidades, os dados encontrados neste estudo foram encaminhados para aquele Ministério, em 04/07/01, para conhecimento, análise e manifestação do órgão responsável pela classificação toxicológica. Até a conclusão deste trabalho, em 25/03/02, não houve resposta.

Com relação à análise do perfil dos produtos comerciais registrados, em termos de Classes de Uso, assim como ocorreu no caso dos ingredientes ativos, também não houve modificação significativa na proporcionalidade de registros entre as classes (inseticidas, fungicidas, herbicidas e "outros"). A classe com maior número absoluto de registros de produtos comerciais no período de referência após a Lei foi a dos inseticidas. Entretanto, o maior crescimento proporcional de registros se deu na classe dos herbicidas. Classe, esta, que desde a década de 1980 detém a maior parte do mercado, em termos de valores de vendas ${ }^{2}$. 
Os resultados apurados mostraram também que $78,2 \%$ dos 863 produtos comerciais que se encontravam registrados após dez anos da promulgação da "Lei dos Agrotóxicos" eram derivados de ingredientes ativos que haviam sido registrados antes da Lei (aqui denominados “antigos"). Mesmo considerando apenas os 461 produtos comerciais identificados como registrados no período após a Lei, a maioria $(59,2 \%)$ deles era derivada de ingredientes ativos "antigos". Quando as Classes de Uso foram analisadas separadamente, apenas na classe "outros" o número de registros dos produtos comerciais derivados dos ingredientes ativos "novos", registrados no período após a Lei, superou os derivados dos "antigos". Entre os inseticidas, fungicidas e herbicidas, os "antigos" prevaleceram, notadamente nesta última classe $(65,8 \%)$.

O perfil da classificação toxicológica dos agrotóxicos registrados no período após a Lei mostra que, apesar do crescimento relativo do número de registros nas classes de menor periculosidade à saúde, para o qual as mudanças que aconteceram nos critérios de classificação toxicológica devem ter contribuído bastante, dois aspectos são preocupantes:

1. as proporções de registros nas diferentes Classes Toxicológicas ainda não foram modificadas a ponto de constituir diferença significativa entre o perfil da classificação toxicológica dos produtos comerciais derivados dos "novos" ingredientes ativos, registrados no periodo após a Lei, em relação ao perfil dos derivados dos "antigos", registrados antes da Lei;

2. ainda houve uma grande proporção de registros $(41,4 \%)$ nas Classes I e II, de maior periculosidade à saúde.

Quando as Classes de Uso foram analisadas separadamente, observou-se que, entre os inseticidas, quase a metade dos produtos $(49,5 \%)$ foi registrada nas Classes Toxicológicas I e II. Ou seja, mesmo apresentando uma tendência de vir a registrar cada vez mais produtos de menor periculosidade, a classe dos inseticidas ainda é a que oferece maior potencial de risco para agravos agudos à saúde. No caso dos produtos comerciais, isto parece decorrer, principalmente, do registro de inseticidas 
derivados dos ingredientes ativos "antigos", que já estavam registrados antes da "Lei dos Agrotóxicos", que quando analisados separadamente tiveram 59,4\% dos registros nas Classes I e II, contra $36,2 \%$ dos inseticidas derivados dos "novos" ingredientes ativos, registrados no período após a Lei. A tendência de menor periculosidade à saúde dos "novos" ingredientes ativos de inseticidas também pode ser observada quando essa proporção de registros de inseticidas nas Classes Toxicológicas I e II $(36,2 \%)$ é comparada às proporções de registros, nessas mesmas Classes Toxicológicas, dos fungicidas $(38,5 \%)$ e herbicidas $(39,2 \%)$ derivados dos "novos" ingredientes ativos.

No caso dos herbicidas, comparando-se os produtos comerciais registrados derivados dos "antigos" ingredientes ativos com os derivados dos "novos" ingredientes ativos, a proporção de registros nas Classes Toxicológicas I e II praticamente se manteve, mostrando que não houve muita evolução nesse aspecto. Já com os fungicidas ocorreu o inverso do esperado: os produtos comerciais derivados dos "novos" ingredientes ativos apresentaram uma proporção de registros nas Classes I e II quase duas vezes maior (38,5\%) do que os derivados dos "antigos" $(19,6 \%)$, indicando que, do ponto de vista dos agravos agudos à saúde, os novos fungicidas derivados dos novos ingredientes ativos podem apresentar um maior potencial de risco do que os "antigos".

Com relação à destinação dos produtos registrados no período após a Lei, as culturas que já eram destinatárias de grande número de produtos, de maneira geral, continuaram a receber um grande número de registros e conseqüentes grandes percentuais de crescimento de registros, destacando-se: ornamentais, soja, algodão, tomate, citros, milho, feijão, café, arroz, batata, trigo e cana-de-açúcar. Essas culturas, de modo geral, também são as destinatárias das maiores vendas de agrotóxicos ${ }^{69}$. Em contraste com o alto número de registros para essas culturas, chama a atenção o baixo número e até o decréscimo de registros para outras destinações.

Esses dados mostram claramente o peso do mercado dos agrotóxicos na definição da "cesta" de ofertas de novos registros: muitas alternativas químicas para 
as "grandes" culturas e poucas ou nenhuma para as culturas minoritárias. No caso das "grandes" talvez haja até um certo exagero de oferta, o que se por um lado pode ser bom por permitir alguma concorrência e possibilidade de escolha, por outro lado pode impulsionar o técnico que indica ou o usuário a escolher um produto de maior periculosidade por razões econômicas, pois, geralmente, produtos mais antigos, de patente vencida, tendem a ser mais baratos ${ }^{25}$. Daí a necessidade de estabelecer estratégias econômicas de taxações e controle de preços visando direcionar o interesse do produtor para os produtos de menor periculosidade ${ }^{\mathbf{2 6}}$.

Já no caso das culturas minoritárias, a escassez de alternativas químicas induz ao uso de produtos não registrados para aquela finalidade, com todos os riscos que isso representa para o usuário e para a população consumidora. É preciso estabelecer estratégias para amenizar esta carência, como fez a Agência de Proteção Ambiental $(E P A)^{79}$ dos EUA, que até criou, em 1998, um departamento especialmente para lidar com este tema. Em conjunto com o Departamento de Agricultura (USDA), a agência estabeleceu canais de comunicação com produtores rurais visando possibilitar discussões sobre suas necessidades e preocupações e estimular a produção e a submissão de dados e informações sobre o uso, quantidades empregadas e resíduos obtidos pelo "uso real" de agrotóxicos, para subsidiar avaliações de risco detalhadas, principalmente com o intuito de promover o registro e uso de produtos de menor periculosidade para culturas minoritárias e acelerar a disponibilidade de alternativas aos organofosforados, carbamatos e alguns produtos classificados como possíveis carcinógenos pela $\mathrm{EPA}^{79}$. A expectativa da EPA para o ano 2000 era avaliar mais de 100 solicitações, envolvendo cerca de 40 ingredientes ativos, que poderiam resultar em 300 novos registros para culturas minoritárias.

Com relação à classificação toxicológica dos novos produtos registrados, quando analisada por destinação, pôde ser observada uma tendência de menor periculosidade à saúde na maioria dos casos. No entanto, algumas das principais culturas/produtos de destinação, mesmo com grande número de registros, ainda tiveram a maior parte dos novos produtos classificados nas classes de maior periculosidade, como ocorreu no fumo, no algodão e no feijão. Nestas culturas a Classe I, inclusive, superou a Classe II. 
Isto também ocorre com outras culturas/produtos de destinação, onde, mesmo contando com a maioria dos registros nas classes de menor periculosidade à saúde, foram identificados mais registros na Classe I, ou até números iguais ou muito próximos de registros, do que na Classe II. Nos casos onde o número total de registros é baixo, talvez, analisando caso a caso, este fato possa ser relevado devido à necessidade de oferecer um meio para controlar determinada praga ou doença. No entanto, nas culturas/produtos de destinação onde o número de registros foi relativamente alto o fato já merece uma atenção maior, como por exemplo nos casos da soja, ornamentais, tomate, citros, milho, café, batata, trigo, cana-de-açúcar, maçã, cebola e uva.

A classificação do potencial de periculosidade ambiental - CPA - apresenta uma complexidade maior do que a classificação toxicológica, do ponto de vista do número de parâmetros envolvidos na avaliação que a determina. Por esta razão, também dificulta uma análise mais específica dos impactos potenciais de produtos classificados nas suas diferentes classes. A sua gradação, porém, deve permitir diferenciar entre os de maior e menor capacidade potencial de produzir danos ao ambiente.

Considerando-se as diferentes Classes de Uso, é a dos inseticidas que apresenta maior proporção e maior número absoluto de registros na Classe I Produto Altamente Perigoso, indicando que, além da saúde, também no caso do ambiente se faz necessário uma atenção especial para com estes produtos.

Mas em quase $50 \%$ das 76 culturas/produtos de destinação para as quais foi possivel identificar ao menos um produto com CPA, a proporção do total de registros na Classe I (produto altamente perigoso) e II (produto muito perigoso) se iguala ou supera a proporção do total nas Classes III (produto perigoso) e IV (produto pouco perigoso), indicando grande potencial de periculosidade ambiental.

Causa preocupação o fato de que, tanto entre os produtos derivados dos "antigos" ingredientes ativos, registrados antes da Lei, como entre os derivados dos 
"novos" ingredientes ativos, registrados no periodo após a Lei, a maior proporção deles está registrada na Classe II - Produto Muito Perigoso, mostrando que, quanto aos danos potenciais ao ambiente, não há muita diferença entre eles.

Talvez um dos motivos para que haja maior proporção de produtos classificados nessa classe seja a aplicação do Artigo 29 da Portaria Normativa ${ }^{\circ}$ 84/96 do $\mathrm{IBAMA}^{37}$ que diz: "Tendo o solicitante cumprido o estabelecido nesta portaria e seus anexos, a não manifestação deste IBAMA dentro do prazo previsto na legislação, implicará na imediata expedição da avaliação do potencial de periculosidade ambiental, enquadrando o produto na Classe II - Muito perigoso."

Mas cabe aqui uma questão maior: afinal, de que serve classificar toxicologicamente e ambientalmente os agrotóxicos se isso não implica qualquer tipo de controle? Que diferença faz um produto ser Classe I ou Classe IV se eles podem ser disponibilizados e comercializados da mesma forma? Não se leva em consideração que os produtos mais perigosos requerem mais conhecimento e capacidade técnica, além de melhor estrutura tecnológica, para seu emprego. Portanto, não poderiam ser indicados, receitados ou comercializados para qualquer usuário. É preciso definir quais devem ser as implicações de ordem técnica, administrativa, econômica e legal na recomendação, na comercialização e no uso, correspondentes a cada Classe Toxicológica e de Periculosidade Ambiental. Caso contrário, essas classificações não cumprem outro papel senão o de alertar para a periculosidade de uma determinada substância, deixando a desejar, porém, quanto a finalidade de proteção da saúde e do ambiente.

Com relação ao exemplo do comportamento dos registros de produtos para o controle do "pulgão do algodoeiro" temos a considerar que a cultura do algodão é a destinação que contava com o maior número de registros (196) em 1990 e no ano 2000 (274) e que contou com o maior número de registros de inseticidas (94) no período após a Lei. Boa parte desses "novos" inseticidas (40) inclui o "pulgão do algodoeiro" entre as pragas controladas. Dos 77 inseticidas que estavam registrados antes da Lei para o controle do "pulgão", a maioria estava na Classe Toxicológica I $(53,2 \%)$, que juntamente com a Classe II somavam $84,4 \%$ dos produtos para essa 
finalidade nas classes de maior periculosidade à saúde. Os demais $(15,6 \%)$ estavam classificados na Classe III. Não havia produtos registrados na Classe IV.

Entre 1990 e 2000 há a indicação que 18 inseticidas deixaram de ser registrados para essa finalidade. A metade deles pertencia a Classe I, porém, proporcionalmente, esta foi a Classe Toxicológica que menos perdeu, $22 \%$, quando comparada às demais classes, que perderam $25 \%$ cada.

Aos 59 produtos comerciais que ainda restaram para o controle do "pulgão do algodoeiro" foram somados mais 40 novos inseticidas, até o ano 2000 . No entanto, a distribuição dos novos registros segundo as Classes Toxicológicas praticamente não se alterou e, conseqüentemente, também não implicou mudanças nas proporções entre as Classes Toxicológicas do conjunto de inseticidas que estavam registrados para o controle do "pulgão do algodoeiro" em 2000, se comparadas a 1990. Mesmo considerando a mudança nos critérios da classificação toxicológica provocada pela Portaria $\mathrm{n}^{0} 3 / 92^{54}$, ainda foram registrados $40 \%$ dos produtos na Classe I extremamente tóxico e $32,5 \%$ na Classe II - altamente tóxico e somente $20 \%$ na Classe III e 7,5\% na Classe IV. Ou seja, observou-se comportamento inversamente proporcional ao que seria interessante para que, de fato, pudesse ser formado um conjunto de alternativas químicas com melhor perfil de toxicidade para o controle de uma das principais pragas de uma das culturas que mais consome agrotóxicos de alta toxicidade aguda.

Verificou-se, ainda, que $65 \%$ dos produtos comerciais registrados no período após a Lei para o controle do "pulgão" eram derivados dos "antigos" ingredientes ativos, registrados antes da Lei, influenciando bastante nas proporções de registros nas Classes Toxicológicas I e II anteriormente mencionadas, que juntas totalizaram $72,5 \%$. Já considerando apenas os inseticidas derivados de ingredientes ativos "novos", registrados no período após a Lei, observou-se uma menor proporção de produtos nas Classes I $(21,4 \%)$ e II $(28,6 \%)$. Mesmo assim, ainda somaram $50 \%$ dos produtos nessas classes. 
Estes dados do exemplo do "pulgão do algodoeiro" evidenciam, pelo menos, três aspectos importantes, que também estão relacionados aos demais resultados comentados anteriormente e que passamos a discutir.

O primeiro é sobre o cumprimento dos artigos da legislação ${ }^{10,12,54}$ que só permitem o registro de novo agrotóxico se o produto for comprovadamente igual ou de menor toxicidade aos já registrados para o mesmo fim. Afinal, como mostra o exemplo do "pulgão", registrar 16 novos produtos na Classe Toxicológica I quando já havia 25 nessa classe e registrar mais 13 na Classe II quando já havia 21 registrados na mesma classe, seguramente deveria levar a uma reflexão sobre a real necessidade desses registros, do ponto de vista agronômico e da necessidade fitossanitária dos mesmos, e não apenas de mercado. Isto sem considerar a ordem cronológica em que esses registros ocorreram, devido à indisponibilidade da informação sobre a data exata dos registros dos agrotóxicos, pois é possível que, mesmo considerando apenas os produtos registrados no período após a Lei, tenham ocorrido registros de produtos de maior toxicidade após outros de menor toxicidade, contrariando a Lei em um dos seus pontos que foi considerado dos mais importantes para diminuir os problemas relacionados aos agrotóxicos.

O segundo é que essa prevalência de produtos "antigos", registrados antes da Lei, e de produtos registrados após a Lei porém derivados de ingredientes ativos “antigos", de certo modo, mostra o impacto negativo do Decreto $n^{\circ} 991 / 93^{11}$, que revogou a necessidade de renovação periódica de registro. Os resultados discutidos indicam que, na prática, conforme comentado na introdução deste trabalho, a ausência da reavaliação periódica, à luz de novos conhecimentos e testes mais modernos e precisos, permite a permanência de registros de produtos que, talvez, por suas características toxicológicas e ambientais de maior periculosidade, já pudessem ter sido eliminados.

Os EUA, bem antes do Brasil, passaram por um processo semelhante ao que vem ocorrendo aqui. A FIFRA, principal lei dos EUA sobre pesticidas, baixada em 1947, previa renovação de registro de pesticidas a cada cinco anos ${ }^{\mathbf{3 0}}$, como a nossa legislação antes do Decreto $991 / 93^{11}$. Mas essa renovação, assim como a nossa, tinha 
mais um caráter burocrático, para identificar quais produtos os registrantes queriam manter, do que de reavaliação técnica visando atualização de dados. Na década de 1960, à medida que mais informações eram requeridas e mais registros solicitados o Departamento de Agricultura dos EUA (USDA) foi cada vez mais deixando de lado a renovação até que abandonou o procedimento no final da década. Mesmo porque, em 1964, a legislação foi emendada, passando a permitir abertura de processos para o cancelamento de registros de produtos por riscos considerados inaceitáveis.

Porém, segundo GRAY ${ }^{30}$....O processo de cancelamento adotado pelo Congresso protegia bastante os direitos processuais dos registrantes; ele permitia que eles recorressem a um comitê consultivo e também a uma espécie de julgamento formal. Esses procedimentos fizeram com que fosse abandonada ....a idéia de que o registro é um direito temporário para vender um agrotóxico, que pode ser renovado periodicamente, mas apenas se ele é reavaliado e considerado que satisfaz os requisitos atualizados. No seu lugar surgiu a idéia do registro como um tipo de direito de propriedade permanente, que só pode ser retirado por meio de um processo judicial, uma idéia que ainda é familiar com a atual legislação e prática. Pode-se dizer que também é bastante similar ao que ocorreu aqui para justificar o fim da renovação de registro: a alegação de que a renovação periódica sobrecarregava os órgãos registrantes e a salvaguarda de que a legislação permite a solicitação de reavaliação de qualquer produto a qualquer tempo.

Entretanto, no caso dos EUA foi estabelecido um programa chamado de reregistro, com prazos e metas estabelecidas para reavaliar todas as substâncias que foram registradas antes de novembro de 1988, com o objetivo de ....assegurar que os agrotóxicos antigos atendam aos padrões contemporâneos de saúde, segurança $e$ rotulagem e que seus riscos sejam adequadamente mitigados ${ }^{79}$. Em 1996, uma nova legislação, a FQPA (Food Quality Protection Act) acrescentou novas dimensões ao programa, estabelecendo novos padrões para resíduos em alimentos e solicitando a reavaliação das tolerâncias existentes num prazo de $10 \operatorname{anos}^{79}$.

Segundo a $\operatorname{EPA}^{79}$ o programa de reregistro vem conseguindo avanços significativos na redução de riscos, permitindo que produtos reavaliados possam ser 
utilizados de maneira mais segura, com maior proteção de usuários, da população em geral e do ambiente, com medidas como: estabelecimento de limites para quantidades, freqüência e épocas de aplicação; melhoria das instruções de utilização e de aplicações; salvaguardas para águas subterrâneas e superficiais; requisitos para uso de equipamentos de proteção individual durante a aplicação; programas especiais para aumentar a proteção de crianças; cancelamento de usos de agrotóxicos. De novembro de 1988 até o final de 1999, o programa cumpriu $70 \%$ da meta de rever as 612 substâncias inicialmente propostas, sendo 198 realizadas pela EPA e 231 voluntariamente canceladas pelos registrantes ${ }^{79}$. Após o término do reregistro a legislação prevê que a EPA terá que estabelecer um programa de reavaliação periódica de todos os pesticidas registrados.

Aqui no Brasil o Ministério da Saúde tomou a iniciativa de reavaliar algumas substâncias de grande periculosidade e seus produtos, como o paration metílico e o metamidofós $^{52}$, por exemplo. No entanto, provavelmente devido à limitada capacidade de trabalho desses órgãos, o número de revisões de registros ainda é pequeno, considerando os resultados discutidos neste trabalho, mostrando, por um lado, as grandes proporções de produtos de maior periculosidade ainda registrados e por outro o aumento expressivo de intoxicações nos últimos anos.

O terceiro aspecto suscitado pelos resultados obtidos é o da provável maior facilidade e conseqüente agilidade (e talvez menor custo) em se registrar produtos derivados de substâncias já registradas, mesmo que essas substâncias sejam de maior toxicidade que outras novas, ainda não registradas. No exemplo do "pulgão do algodoeiro", a proporção é de quase dois registros de produtos comerciais derivados de substâncias "antigas" para cada registro de produto derivado dos "novos" ingredientes ativos. Os dados gerais também mostraram que, no período após a Lei, houve mais registros de produtos derivados dos "antigos" $(59,2 \%)$ ingredientes ativos do que de "novos" (40,8\%).

Considerando esses aspectos, se faz necessário discutir mecanismos administrativos que agilizem o registro de novas substâncias de menor impacto, em detrimento das "antigas", como também vem fazendo a Agência de Proteção 
Ambiental dos Estados Unidos (EPA). A agência ${ }^{79}$ vem dando alta prioridade ao registro de agrotóxicos considerados de menor periculosidade à saúde e ao ambiente, que geralmente é feito na metade do tempo de um registro de um agrotóxico "convencional". Esta estratégia também vem sendo adotada para substitutos de produtos organofosforados. Isto tem permitido um maior número proporcional de registros dos chamados safer-pesticides. No biênio 98-99, por exemplo, dos 53 ingredientes ativos registrados pela EPA, 33 eram safer-pesticides, que incluem biopesticidas (microbiológicos, feromônios etc.) e novos agroquímicos convencionais de baixa-periculosidade ${ }^{79}$. Para ser enquadrado nesta última categoria é necessário que a substância atenda, pelo menos, a uma das seguintes condições: apresente baixo risco à saúde humana, baixa toxicidade para organismos não-alvos e baixo potencial de contaminação de águas subterrâneas e superficiais ou de outros valiosos recursos naturais; possibilite a ampliação do uso e maior efetividade de sistemas de manejo integrado de pragas.

Estratégias semelhantes às adotadas pela EPA deveriam ser estudadas e adotadas pelos nossas autoridades responsáveis pelo registro de agrotóxicos, pois a pouca especificidade dos agrotóxicos de maior toxicidade tende a provocar maiores desequilíbrios nos agro-ecossistemas, trazendo como conseqüência o aumento no número e na severidade da infestação de pragas e doenças e a resistência das espécies combatidas $^{59}$, contribuindo para o aumento no consumo de agrotóxicos e no número de registros de substâncias e produtos comerciais.

Além desses aspectos relacionados ao registro é preciso que os estados e municípios façam valer de forma mais efetiva as suas atribuições de controle, especialmente sobre o uso, o consumo e o comércio dos agrotóxicos, previstas na legislação, conforme reconhece o próprio governo em sua "Proposta" Preliminar para um Programa Nacional de Racionalização do Uso de Agrotóxicos", que foi discutida no âmbito do programa Protocolo Verde, do Governo Federal:

"Os recursos financeiros disponiveis para a implementação dessas ações governamentais (de controle dos agrotóxicos), assim como as capacidades operacionais dos órgãos envolvidos, por serem insuficientes, têm ocasionado um 
acúmulo de sinais de ineficiência do poder público no cumprimento de suas atribuições. Isso se verifica através do agravamento do quadro de contaminação ambiental, do desequilíbrio ecológico, da contaminação de alimentos $e$ intoxicação humana, e de práticas irregulares de comércio e uso de agrotóxicos. Reconhece-se que, dentre os diversos instrumentos que integram o processo de controle governamental sobre esses produtos, os órgãos federais têm desenvolvido uma ação mais intensa em torno do instrumento básico, qual seja o do seu registro, cabendo aos órgãos setoriais respectivos a incumbência de estudar e avaliar as peculiaridades agronômicas, toxicológicas e ambientais de cada produto, para a tomada de decisão quanto à conveniência ou não da concessão daquele registro, e para o estabelecimento das restrições $e$ recomendações de uso que se façam necessárias, visando a maior segurança no seu emprego e a defesa dos interesses da coletividade."

Também é importante introduzir nesta discussão outros fatores que, embora não tenham sido objetos específicos de estudo neste trabalho, certamente tiveram grande peso em seu desenvolvimento: a falta e desatualização de dados sobre registros e os produtos registrados, até mesmo entre os órgãos responsáveis; a ausência de publicidade e transparência sobre os processos de registro, onde nem mesmo a publicação da aprovação do registro é realizada; a ausência de padronização de informações essenciais, como o nome técnico de ingredientes ativos e a identificação precisa das substâncias registradas, por exemplo, por meio da utilização do número de registro do CAS (Chemical Abstracts Service), que é mundialmente reconhecido. Estes e outros fatores dessa natureza não só dificultam o desenvolvimento de pesquisas como a que foi aqui realizada, como, certamente, limitam a capacidade de controle dos próprios órgãos registrantes, dos órgãos de controle e da sociedade em geral, no sentido de conhecer, identificar e acompanhar tudo o que já esteve, está e virá a ser registrado e utilizado como agrotóxico.

Embora os órgãos de governo, tanto federais como alguns estaduais, venham procurando organizar e disponibilizar informações, isto ainda se dá de forma limitada. Tanto que, para atender a demanda, há oferta de informação por empresas privadas, dirigida principalmente a técnicos e usuários de agrotóxicos. Essas 
empresas dispõem de uma melhor capacidade de acompanhamento, atualização e disponibilização de informações, que em sua maioria são geradas pelos próprios órgãos responsáveis por isso. Isto não é novidade: desde 1985 a Editora Andrei publica o Compêndio de Defensivos Agrícolas ${ }^{4}$, com informações técnicas sobre os agrotóxicos registrados, obtidas junto aos próprios órgãos responsáveis pelo registro.

Hoje os meios eletrônicos prevalecem e há um pequeno número de empresas que trabalham com isso, também valendo-se de informações oficiais. $\mathrm{O}$ que, em si, não é um problema, afinal as empresas são mais ágeis na atualização e disponibilização das informações do que o próprio governo, que também disponibiliza informações digitalizadas, embora de forma bem menos ágil. $\mathrm{O}$ problema é que as próprias fontes de informação (órgãos públicos responsáveis) não conseguem manter a informação atualizada, o que se reflete na qualidade da informação oferecida pelas empresas que prestam serviço de divulgação, que por sua vez procuram complementá-las com as empresas que registram e comercializam os produtos.

O interessante é que, no final da década de 1970 e início da seguinte, quando os meios eletrônicos atuais ainda não existiam, o governo federal conseguia publicar - Catálogo dos Defensivos Agrícolas", bem mais completo e detalhado, do que qualquer uma das publicações gráficas ou eletrônicas atuais, mostrando que havia, na época, uma maior capacidade de controle e organização de informação do que hoje. Se faz necessário, então, capacitar e instrumentalizar os órgãos de registro e controle com os meios necessários para exercerem as suas funções de forma ágil, transparente e eficiente.

\footnotetext{
${ }^{*}$ Galvão DM, Pires EA. Catálogo dos defensivos agrícolas. Ministério da Agricultura; 1980.
} 


\section{CONCLUSÕES E SUGESTÕES}

Os dados analisados indicam que após dez anos da promulgação da "Lei dos Agrotóxicos", contrariando as expectativas geradas na ocasião, sua aplicação não trouxe alguns dos avanços esperados, notadamente no que se refere ao controle das ocorrências de intoxicações agudas e nos indicadores de periculosidade à saúde (classificação toxicológica) e ao ambiente (classificação de potencial de periculosidade ambiental) relacionados aos agrotóxicos registrados.

Segundo os dados com abrangência nacional disponíveis sobre o número de intoxicações agudas causadas por agrotóxicos, a aplicação da Lei parece não ter ocasionado interferência no sentido de refrear o crescimento de casos dos últimos 15 anos, o qual provavelmente foi impulsionado pelo expressivo aumento de vendas que ocorreu no período.

O crescimento praticamente contínuo no número de casos de intoxicações possivelmente associado ao aumento das vendas de agrotóxicos indica que é preciso conhecer melhor o que está sendo vendido, ou seja, identificar quais são as substâncias e os produtos mais comercializados, pois é provável que os de maior toxicidade estejam ganhando mercado em detrimento dos de menor periculosidade à saúde. Assim, se faz necessário definir mecanismos de restrição de comercialização e uso e de controle de fatores econômicos que influenciem o consumo de agrotóxicos de maior periculosidade.

$\mathrm{O}$ uso das classificações toxicológica e de potencial de periculosidade ambiental é recomendável para esse fim. Entretanto, no caso da classificação toxicológica a regulamentação da "Lei dos Agrotóxicos" prejudicou essa possibilidade pela mudança nos critérios de classificação determinada pela Portaria 3/92, que, sob a ótica da segurança e saúde no trabalho, teve um forte impacto negativo, por dois fatores principais: 
1. pela reclassificação da maioria dos produtos que estavam registrados para classes de menor periculosidade à saúde, o que pode ter gerado confusão entre os usuários devido às mudanças das faixas coloridas de advertência dos rótulos, levando a comportamentos que podem ter implicado maiores riscos $\mathrm{e}$ maior incidência de intoxicações;

2. por diminuir a probabilidade de um produto ser enquadrado em classes de maior periculosidade à saúde e, portanto, de sofrer restrições de comercialização ou uso, prejudicando assim a capacidade de se empregar o critério da classificação como um meio mais abrangente de controle de riscos.

Tendo em vista que o emprego de agrotóxicos só deveria se dar sob condições bastante controladas, especialmente os de maior periculosidade, é preciso dar o devido valor à finalidade precípua das classificações toxicológica e ambiental, que é definir legalmente quais devem ser as implicações de ordem técnica, administrativa e econômica na recomendação, na comercialização e no uso, correspondentes a cada Classe Toxicológica e de Periculosidade Ambiental. Essa discussão e definição poderia se dar no nível federal, estadual e municipal.

A aplicação da Lei também não atendeu à expectativa de propiciar um conjunto de agrotóxicos registrados que fosse significativamente de menor impacto potencial à saúde (agravos agudos) e ao ambiente.

A permanência do registro de ingredientes ativos e de produtos comerciais de maior periculosidade, que já estavam registrados antes da Lei, e a entrada de registros desse mesmo tipo após a Lei, notadamente de produtos derivados de ingredientes ativos que já estavam registrados antes da Lei, mesmo em culturas para as quais já havia um grande número de produtos registrados, não permitiram, no período estudado, a formação de um conjunto expressivo de ingredientes ativos e de produtos comerciais de agrotóxicos com perfil toxicológico e ambiental de menor impacto. Isto mostra a necessidade de estabelecer mecanismos administrativos que priorizem e agilizem o registro de substâncias e produtos menos impactantes. 
A revogação do procedimento de renovação periódica de registro (Decreto 991/93) e a não aplicação dos instrumentos legais que permitem apenas o registro de agrotóxicos de igual ou menor toxicidade para as mesmas finalidades (parágrafo $5^{\circ}$ do artigo $3^{\circ}$ da Lei $7.802 / 89$ e o artigo $14^{\circ}$ do Decreto $98.816 / 90$ ) podem ter sido determinantes nesses resultados. Re-estabelecer a reavaliação periódica obrigatória das substâncias e produtos registrados e regulamentar melhor os aspectos que proíbem o registro de produtos de maior periculosidade para o mesmo fim, visando uma aplicação eficaz dos mesmos, são recomendados.

Com relação à destinação dos agrotóxicos registrados, a legislação também parece não ter tido nenhum papel preponderante: ela não só não interferiu no crescimento das vendas, como não interferiu no fato do mercado continuar a ser o fator principal de definição da entrada de novos registros, pois as culturas de maior expressão econômica que já eram destinatárias dos maiores números de registros continuaram a sê-lo no período após a Lei e as culturas de menor expressão continuaram a receber menos registros ou até a não receber registro algum.

Isto mostra a necessidade de definir estratégias e mecanismos no processo de registro que permitam avaliar e ponderar a necessidade agronômica de novos registros para culturas que já dispõem de muitos registros, assim como para as culturas que dispõem de poucos ou nenhum registro, privilegiando substâncias e produtos comerciais de menor impacto e considerando também aspectos econômicos.

Por fim, é preciso ressaltar que todos os aspectos analisados e discutidos neste trabalho sofreram grandes limitações pela carência, fragilidade, desatualização, dispersão, desorganização, discrepância e pequena acessibilidade das informações técnicas necessárias para desenvolver estudos desta natureza, que, certamente, também devem prejudicar os próprios órgãos responsáveis, dificultando o necessário controle dos agrotóxicos. Embora seja possível reconhecer um esforço desses órgãos, em âmbito federal e, em alguns poucos casos, também no estadual, no sentido de resgatar, organizar e disponibilizar informações, ainda há muito por fazer para alcançar a agilidade e transparência atualmente exigidas pela sociedade. É preciso garantir as condições necessárias aos órgãos oficiais de controle para esse fim. 
Apesar das dificuldades observadas, entendemos que análises de caráter geral sobre os agrotóxicos registrados, como as realizadas neste trabalho, são necessárias e deveriam ser realizadas com freqüência por entidades de pesquisa e pelos próprios órgãos de controle. Essa prática permitiria enfrentar a pressão econômica de flexibilização das exigências de caráter restritivo oferecendo subsídios para o aprimoramento da legislação e para o desenvolvimento de uma política de registro e de controle dessas substâncias que visasse atender aos anseios da sociedade por um maior controle dos agentes e condições que degradam a saúde e o ambiente na busca de melhor qualidade de vida. 


\section{REFERÊNCIAS}

1. Agrotis. Sistema de Receituário Agronômico. [programa de computador]. Versão 4.0 . Curitiba: Agrotis; atualização Fev./2000.

2. Alves Filho JP. Receituário agronômico: a construção de um instrumento de apoio à gestão dos agrotóxicos e sua controvérsia. São Paulo; 2000. [Dissertação de mestrado - Programa de pós-graduação em ciência ambiental - PROCAM USP].

3. Alves HT. Legislação Básica e controle dos defensivos agrícolas no Brasil. In: ABEAS. Os defensivos agrícolas, utilização, toxicologia e legislação específica. módulo 6 - legislação e normas. Brasília: ABEAS; 1983. (anexo 7).

4. Andrei E. Compêndio de defensivos agrícolas. $3^{\text {a }}$ ed. São Paulo: Andrei; 1990.

5. Aspelin $\mathrm{AL}$, Grube $\mathrm{AH}$. Pesticides industry sales and usage: 1996 and 1997 market estimates. Washington (DC): USEPA; 1999.

6. Associação Nacional de Defesa Vegetal - ANDEF. Vendas 1988 a 1998 [estatísticas on line]. Disponível em <URL: http://www.andef.com.br/ dentro/bmercado.htm >. [2000 jul 31].

7. Batista GC. A nova "Lei dos Agrotóxicos". Notesalq 1990; 3 (14): 7.

8. Bortoletto ME, Marques MB, Bezerra MCC, Santana RAL, Bochner R. Análise epidemiológica dos casos registrados de intoxicação humana no Brasil no período de 1985 - 1993. Rev Bras Toxicol 1996; 9(2): 1-12.

9. Brasil. Decreto $\mathrm{n}^{\circ}$ 24.114, de 14 de abril de 1934. Aprova o Regulamento de Defesa Sanitária Vegetal. In: Gelmini GA, Novo JPS. Defensivos agrícolas: informações básicas e legislação. Campinas: Fundação Cargill; 1987. p. 416423. 
10. Brasil. Decreto $\mathrm{n}^{\circ} 98.816$, de 11 de janeiro de 1990. Regulamenta a Lei 7.802, de 11 de julho de 1989, que dispõe sobre a pesquisa, a produção, a embalagem e rotulagem, o transporte, o armazenamento, a comercialização, a propaganda comercial, a utilização, a importação, a exportação, o destino final dos resíduos e embalagens, o registro, a classificação, o controle, a inspeção e a fiscalização de agrotóxicos, seus componentes e afins, e dá outras providências Legislação federal de agrotóxicos e afins, Brasília, Ministério da Agricultura e do Abastecimento. 1998. p. 15-53.

11. Brasil. Decreto $n^{\circ} 991$, de 24 de novembro de 1993. Altera o Decreto $n^{\circ} 98.816$, de 11/01/1990. Legislação federal de agrotóxicos e afins, Brasília, Ministério da Agricultura e do Abastecimento. 1998. p. 57-59.

12. Brasil. Lei $\mathrm{n}^{\circ} 7.802$, de 11 de julho de 1989. Dispõe sobre a pesquisa, a produção, a embalagem e rotulagem, o transporte, o armazenamento, a comercialização, a propaganda comercial, a utilização, a importação, a exportação, o destino final dos resíduos e embalagens, o registro, a classificação, o controle, a inspeção e a fiscalização de agrotóxicos, seus componentes e afins, e dá outras providências. Legislação federal de agrotóxicos e afins, Brasília, Ministério da Agricultura e do Abastecimento. 1998. p. 7-13.

13. Campanhola C, Rodrigues GS, Bettiol W. Evolução, situação atual, projeção e perspectiva de sucesso de um programa de racionalização do uso de agrotóxicos no Brasil. [Apresentado no Seminário Internacional de Racionalização do Uso de Pesticidas no Cone Sul; 1997 set 17 e 18; Campinas, SP].

14. Cohen J. A coefficient of agreement for nominal scales. Educ Psych Meas 1960; 20:37-46.

15. Contaminação na lavoura. Proteção 1996; 55(jul.): 28-29. 
16. Copplestone JF. The development of the WHO Recommended Classification of Pesticides by Hazard. Bulletin of the World Health Organization 1988; 66(5): $545-551$.

17. Costa Neto PLO. Estatística. São Paulo: Edgard Blücher;1977. Correlação e regressão; p. 178-228.

18. Coye MJ. The health effects of agricultural production: I - the health of agricultural workers. J Publ Health Policy 1985; 6: 349-70.

19. Dean AG, Dean JA, Coulombier D, Brendel KA, Smith DC, Burton AH, Dicker RC, Sullivan K, Fagan RF, Arner TG. Epi Info, Version 6: A Word-Processing, Database, and Statistics Program for Public Health on IBM-compatible Microcomputers. [programa de computador]. Versão 6.04b. Atlanta: Centers for Disease Control and Prevention; 1995.

20. Ferreira CRRPT. Defensivos agrícolas: situação de mercado. Inf Econ 2000; 30 (10): $57-60$.

21. Ferreira CRRPT e Carvalho FC. O setor de defensivos agrícolas no Brasil: evolução e tendências. Inf Econ 1985; 15 (5): 23-33.

22. Ferreira Lima LC. Evolução na história dos agrotóxicos. Defesa Vegetal 1991; 29: 12 .

23. Fragomeni G. Prevention of pesticide-related risks: role of the European Union regulation harmonization. Pesticide Safety News 1997; 1 (jun): 6-7.

24. Fundação IBGE. Censo agropecuário: 1995-1996. Rio de Janeiro; 1998. n.1, Brasil.

25. Futino AM e Silveira JMJF. A indústria de defensivos agrícolas no Brasil. Agricultura em São Paulo 1991; 38 (Tomo esp.): 1-43. 
26. Garcia EG. Segurança e saúde no trabalho rural: a questão dos agrotóxicos. São Paulo: Fundacentro; 2001.

27. Garcia EG. Pesticide control experiences in Brazil. Pesticide Safety News 1997; 2 (Sept): 5 .

28. Garcia EG, Almeida WF. Exposição de trabalhadores rurais aos agrotóxicos no Brasil. Rev. Bras. Saúde Ocup 1991; 19 (72): 7-11.

29. Garçoni C. Agrotóxicos. Casa da Agricultura 1989; 11(jul./ago.): 8-10.

30. Gray EC. A short history of pesticide reregistration. In: Marco GJ, Hollingworth RM, Plimmer JR, editors. Regulation of agrochemicals: a driving force in their evolution. Washington (DC): ACS; 1991. p.45-54.

31. Henao S, Corey G. Plaguicidas inhibidores de las colinesterasas. Metepec, México: ECO/OPS; 1991. (Serie Vigilancia - 11).

32. Hora de agir com bom senso. Defesa Vegetal 1985; $2(7): 3$.

33. International Labour Office - ILO. Safety and health in the use of agrochemicals: a guide. Geneva; 1991.

34. Infortúnio no campo. Proteção 1990; 2 (9): 172-188.

35. Instituto Brasileiro do Meio Ambiente e dos Recursos Naturais Renováveis IBAMA. Portaria Normativa $\mathrm{n}^{\circ} 349$, de 14 de março de 1990. Estabelece os procedimentos a serem seguidos junto ao IBAMA para efeito de registro, renovação de registro e extensão de uso para agrotóxicos. Diário Oficial da União, Brasília, 14 de mar. 1990. Seção I, p. 5256-5257. 
36. Instituto Brasileiro do Meio Ambiente e dos Recursos Naturais Renováveis IBAMA. Portaria Normativa $n^{\circ} 139$, de 21 de dezembro de 1994. Estabelece procedimentos a serem adotados junto ao IBAMA para efeito de avaliação do potencial de periculosidade ambiental de produtos químicos considerados como agrotóxicos. Legislação federal de agrotóxicos e afins, Brasília, Ministério da Agricultura, do Abastecimento e da Reforma Agrária. 1995. p. 77-87.

37. Instituto Brasileiro do Meio Ambiente e dos Recursos Naturais Renováveis IBAMA. Portaria Normativa $\mathrm{n}^{\circ} 84$, de 15 de outubro de 1996. Estabelece procedimentos a serem adotados junto ao IBAMA para efeito de registro e avaliação do potencial de periculosidade ambiental (ppa) de agrotóxicos. Legislação federal de agrotóxicos e afins, Brasília, Ministério da Agricultura e do Abastecimento. 1998. p. 91-131.

38. Jeyaratnam J. Occupational health issues in developing countries. Environmental Research 1993; 60: 207-212.

39. Kohn GK. Agrochemicals and the regulatory process before 1970. In: Marco GJ, Hollingworth RM, Plimmer JR, editors. Regulation of agrochemicals: a driving force in their evolution. Washington (DC): ACS; 1991. p.1-7.

40. Landis JR, Koch GG. The measurement of observer agreement for categorical data. Biometrics 1977; 33: 159-74.

41. Lazzarini W. Uma vitória dos consumidores. Casa da Agricultura 1989; 11(jul./ago.): 11-12.

42. Levitan L. An overview of pesticide impact assessment systems based on indexing or ranking pesticides by environmental impact. [Background paper prepared for the Organization of Economic Cooperation and Development (OECD) workshop on pesticide risk indicators; 1997 April 21-23 (revised May 19, 1997); Copenhagen]. 
43. Menezes FAF. Antes tarde do que nunca. Ciência Hoje 1986; 4 (22): 57.

44. Ministério da Agricultura. Secretaria de Defesa Sanitária Vegetal - SDSV. Portaria $\mathrm{n}^{\circ} 06$, de 8 de fevereiro de 1985. Aprova normas sobre registro e renovação de produtos fitossanitários ou defensivos agrícolas. In: Gelmini GA, Novo JPS. Defensivos agrícolas: informações básicas e legislação. Campinas: Fundação Cargill; 1987. p. 511-523.

45. Ministério da Agricultura. Secretaria Nacional de Defesa Agropecuária - SNDA. Portaria $\mathrm{n}^{\circ} 45$, de 10 de dezembro de 1990 . Estabelece os procedimentos para obtenção do registro de agrotóxicos e os testes sobre a eficiência e praticabilidade agronômica. Legislação federal de agrotóxicos e afins, Brasília, Ministério da Agricultura e do Abastecimento. 1998. p. 63-66.

46. Ministério da Agricultura. Secretaria de Defesa Agropecuária - SDA. Portaria $n^{\circ}$ 67, de 30 de maio de 1995. Dispõe sobre a mistura em tanque de agrotóxicos. Legislação federal de agrotóxicos e afins, Brasília, Ministério da Agricultura e do Abastecimento. 1998. p. 71-73.

47. Ministério da Agriculutra. Vendas de Defensivos Agrícolas, por Tipos - Brasil 1990/1999. [estatística on line] Disponivel em <URL: http://www. agricultura.gov.br/ /Estatísticas/343htm $>$ [2000 jul 23]

48. Ministério da Agricultura e Abastecimento. Agrofit 98. Informações de produtos fitossanitários registrados no MA. [programa de computador]. Brasília, Coordenação de Fiscalização de Agrotóxicos; 1998.

49. Ministério da Agricultura e Ministério da Saúde. Portaria n² 220, de 14/03/79. Disciplina rotulagem de defensivos agrícolas. In: Gelmini GA e Novo JPS. Defensivos agrícolas: informações básicas e legislação. Campinas: Fundação Cargill; 1987. p.436-445. 
50. Ministério da Saúde. Agência Nacional de Vigilância Sanitária. Monografias de produtos agrotóxicos [monografias on line]. ANVISA. Brasília: ANVISA; 2000. Disponível em <URL:http://www.anvisa.gov.br/ legis/resol/05_99rdc.htm>. [2000 Jul 10]

51. Ministério da Saúde. Agência Nacional de Vigilância Sanitária. Resolução RDC $n^{0} 5$, de 14/10/99. Suspende a aprovação e a avaliação toxicológica para registro de novas formulações de produtos agrotóxicos com a mistura de princípios ativos considerados potencialmente carcinogênicos. [legislação on line]. ANVISA. Brasília: ANVISA; 1999. Disponível em <URL:http://anvs1.saude.gov.br/, toxicologia/toxicologia/leis\%20html/L-61.htm>. [2000 Mar 28]

52. Ministério da Saúde. Agência Nacional de Vigilância Sanitária. Resolução RDC $n^{\circ} 6$, de 14/10/99. Suspende a aprovação e a avaliação toxicológica para registro de novos produtos técnicos e/ou formulações de agrotóxicos à base de Paration Metílico e Metamidofós. [legislação on line]. ANVISA. Brasília: ANVISA; 1999. Disponível em <URL:http://anvs1.saude.gov.br/toxicologia/toxicologia/leis\%20 $\mathrm{html} / \mathrm{L}-62 . \mathrm{htm}>$. [2000 Mar 28]

53. Ministério da Saúde. Divisão Nacional de Vigilância Sanitária de Produtos Saneantes Domissanitários - DISAD. Portaria $n^{\circ} 4$, de 30 de abril de 1980. Estabelece normas para a classificação toxicológica de defensivos agrícolas. In: Gelmini GA, Novo JPS. Defensivos agrícolas: informações básicas e legislação. Campinas: Fundação Cargill; 1987. p. 453-464.

54. Ministério da Saúde. Secretaria Nacional de Vigilância Sanitária - SNVS. Portaria $\mathrm{n}^{\circ} 03$, de 16 de janeiro de 1992. Ratifica os termos das "Diretrizes e orientações referentes à autorização de registros, renovação de registro e extensão de uso de produtos agrotóxicos e afins - $\mathrm{n}^{\circ} 1$, de 09/12/91". Legislação federal de agrotóxicos e afins, Brasília, Ministério da Agricultura e do Abastecimento. 1998. p. $153-177$. 
55. Organización de las Naciones Unidas para la Agricultura y la Alimentación FAO. Código internacional de conducta para la distribución y utilización de plaguicidas (versión enmendada). Roma; 1990.

56. Organización Internacional del Trabajo - OIT. Situación reciente del trabajo en las plantaciones. Ginebra; 1994. (Comissión del trabajo en las plantaciones, décima reunión, informe I).

57. Osteen C. Pesticide use trends and issues in the United States. In: Pimentel D. e Lehman $\mathrm{H}$, editors. The pesticide question - environment, economics, and ethics. New York: Chapman \& Hall; 1993. p. 307-336.

58. Pan American Health Organization - PAHO. Pesticides and health in the Americas. Washington, DC; 1993. (Environmental Series $\mathrm{n}^{\circ} 12$ ).

59. Paschoal, A.D. Pragas, praguicidas e a crise ambiental: problemas e soluções. Rio de Janeiro: Fundação Getúlio Vargas; 1979.

60. Pessanha BMR e Menezes FAF. A questão dos agrotóxicos. Agroanalysis 1985; 9 (9): 2-22.

61. Poltroniéri LC. O custo social do uso de praguicidas na agricultura por intoxicações: identificação de áreas de risco no Estado de São Paulo no período 1992/1994. Rio Claro; 1997. [Tese de livre-docência - Departamento de Geografia, do Instituto de Geociências e Ciências Exatas da UNESP, Campus de Rio Claro].

62. Receita agronômica: nova ameaça ao setor. Química e Derivados 1979; julho: 12-26.

63. Registro: mercado interno e Mercosul. Defesa Vegetal 1997; jan: 2. 
64. Rola A, Pingali P. Pesticides, rice productivity and health impacts in the Philippines. In: Faeth P. Agricultural policy and sustainability. Washington: World Resources Institute; 1993. p. 47-62.

65. SAS Institute. SAS/STAT [programa de computador]. Release 8. N.C.: Cary; 1999.

66. Selvin S. Statistical analysis of epidemiologic data. 2th ed. New York: Oxford University; 1996. p.174-178.

67. Silva EF, Pereira MG. Avaliação das estruturas de concordância e discordância nos estudos de confiabilidade. Rev Saúde Pública 1998; 32: 383-93.

68. Simon W. Retrocesso preocupante no Mercosul. Defesa Vegetal 1997; out: 4.

69. Sindicato Nacional da Indústria de Produtos para Defesa Agrícola - SINDAG. Vendas de defensivos agrícolas por culturas de destinação e classes - 1997/2000 [estatísticas on line]. Disponível em <URL: http://www.sindag.com.br/db/arqs/ CULTURAS-9700.xls $>$. [2001 jul 17].

70. Sistema Nacional de Informações Tóxico-Farmacológicas - SINITOX. Estatística anual de casos de intoxicação e envenenamento. Brasil, 1994. Rio de Janeiro: FIOCRUZ, 1996.

71. Sistema Nacional de Informações Tóxico-Farmacológicas - SINITOX. Estatística anual de casos de intoxicação e envenenamento. Brasil, 1995. Rio de Janeiro: FIOCRUZ, 1997.

72. Sistema Nacional de Informações Tóxico-Farmacológicas - SINITOX. Revisão da Estatística de 1995. Casos de intoxicação e envenenamento. Brasil, 1995. Rio de Janeiro: FIOCRUZ, 1998. 
73. Sistema Nacional de Informações Tóxico-Farmacológicas - SINITOX. Estatística anual de casos de intoxicação e envenenamento. Brasil, 1996. Rio de Janeiro: FIOCRUZ, 1998.

74. Sistema Nacional de Informações Tóxico-Farmacológicas - SINITOX. Casos Registrados de Intoxicação Humana por Agente Tóxico e Causa Determinante. Brasil, 1997 [Estatística on line]. Rio de Janeiro: FIOCRUZ; 2001. Disponivel em <URL: http://www.fiocruz.br/cict/sinitox/ tabela011997.htm>. [31 julho 2001].

75. Sistema Nacional de Informações Tóxico-Farmacológicas - SINITOX. Casos Registrados de Intoxicação Humana por Agente Tóxico e Causa Determinante. Brasil, 1998 [Estatística on line]. Rio de Janeiro: FIOCRUZ; 2001. Disponível em <URL: http://www.fiocruz.br/cict/sinitox/ tabela011998.htm>. [31 julho 2001].

76. Sistema Nacional de Informações Tóxico-Farmacológicas - SINITOX. Casos Registrados de Intoxicação Humana por Agente Tóxico e Circunstância. Brasil, 1999. [Estatística on line]. Rio de Janeiro: FIOCRUZ; 2001. Disponível em <URL: http://www.fiocruz.br/cict/sinitox/tabela011999.htm>. [31 julho 2001].

77. Soares PR. Protocolo Verde / Brasil - PNRUA - Proposta Preliminar para um Programa Nacional de Racionalização do Uso de Agrotóxicos. [Apresentado no Seminário Internacional de Racionalização do Uso de Pesticidas no Cone Sul; 1997 set 17 e 18; Campinas, SP].

78. Thomas B. Pesticide Registration in Europe. In: Marco GJ, Hollingworth RM, Plimmer JR, editors. Regulation of agrochemicals: a driving force in their evolution. Washington, DC: ACS; 1991. p.73-9.

79. United States Environmental Protection Agency. Office of pesticide programs biennial report for fiscal year 1998 and 1999. Washington (DC); 1999. 
80. World Health Organization - WHO. Public health impact of pesticides used in agriculture. Geneva; 1990.

81. World Health Organization - WHO. The WHO recommended classification of pesticides by hazard and guidelines to classification 1990-1991. [documento on line]. International Programme on Chemical Safety - IPCS. Document WHO/PCS/90.1 Rev1. Disponível em <URL: http://whqlibdoc.who.int/hq/1990/ /WHO_PCS_90.1_REV.1.pdf $>$ [2000 Mai 19].

82. World Health Organization - WHO. The WHO recommended classification of pesticides by hazard and guidelines to classification 1998-1999. [documento on line]. International Programme on Chemical Safety - IPCS. Document WHO/PCS/90.1 Rev.1. Disponível em <URL: http://whqlibdoc.who.int/hq/1998/ /WHO_PCS_98.21.pdf>[2000 Mai 19]. 
8. ANEXOS 


\section{ANEXO 1 - banco de dados no 1 - Ingrediente Ativo}

\section{LEGENDA:}

- USO ( Classe de Uso): I - inseticida ; F - Fungicida ; H - Herbicida ; $\mathrm{O}$ - "outros".

- 1990 (confirma registro em 1990): Y - Sim ; N - Não

- 2000 (confirma registro em 2000): Y - Sim ; N - Não

- OMS90 (classe de periculosidade atribuída pela OMS, 1990):

$\mathrm{Ia}$ - extremely hazardous ; $\mathrm{Ib}$ - highly hazardous ; II - moderately hazardous ;

III - slightly hazardous ; $U$ - unlikely to present acute hazard in normal use

- OMS98 (classe de periculosidade atribuída pela OMS, 1998): hazardous ;

Ia - extremely hazardous ; lb - highly hazardous ; II - moderately

III - slightly hazardous ; U - unlikely to present acute hazard in normal use

- CTMS (Classe Toxicológica atribuída pelo Ministério da Saúde, 2000):

I - extremamente tóxico ; II - altamente tóxico ; III - medianamente tóxico ; IV - pouco tóxico

\begin{tabular}{|c|c|c|c|c|c|c|}
\hline INGREDIENTES ATIVOS & USO & 1990 & 2000 & OMS90 & OMS98 & CTMS \\
\hline 2,4-D & $\mathrm{H}$ & $Y$ & $Y$ & 11 & 11 & II \\
\hline ABAMECTIN & 1 & Y & Y & & & 1 \\
\hline ACEPHATE & 1 & $\mathrm{Y}$ & $Y$ & III & III & III \\
\hline ACETAMIPRID & 1 & $\mathrm{~N}$ & Y & & & III \\
\hline ACETOCHLOR & $\mathrm{H}$ & $N$ & $Y$ & & III & III \\
\hline ACIDO GIBERELICO & 0 & $N$ & $Y$ & & $\mathrm{U}$ & IV \\
\hline ACIDO PROPIONICO & 0 & Y & $\mathbf{N}$ & & & \\
\hline ACIFLUORFEN SODIUM & $\mathrm{H}$ & Y & Y & III & III & 1 \\
\hline ACRINATHRIN & 1 & $\mathrm{~N}$ & Y & & $U$ & II \\
\hline AGENTE TENSOATIVO ANIONICO & 0 & Y & Y & & & \\
\hline
\end{tabular}


(continuação do Anexo I)

\begin{tabular}{|c|c|c|c|c|c|c|}
\hline INGREDIENTES ATIVOS & USO & 1990 & 2000 & OMS90 & OMS98 & CTMS \\
\hline ALACHLOR & $\mathrm{H}$ & $\mathrm{Y}$ & $\mathrm{Y}$ & III & la & III \\
\hline ALCOOFENOIS & 0 & $\mathrm{Y}$ & Y & & & \\
\hline ALCOOL ISOPROPILICO & 0 & $Y$ & Y & & & \\
\hline ALCOOL POLIVINILICO & 0 & $Y$ & Y & . & 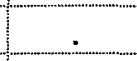 & 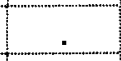 \\
\hline ALDICARB & 1 & Y & Y & la & la & 1 \\
\hline ALDRIN & 1 & $Y$ & $N$ & $\mathrm{Ib}$ & 0 & II \\
\hline ALFACIPERMETRINA & 1 & $N$ & Y & & II & II \\
\hline ALLOXYDIM-SODIUM & $\mathrm{H}$ & Y & Y & $U$ & $U$ & III \\
\hline ALQUIL ESTER ETOXILADO AC.FOSF & 0 & $N$ & Y &. & . & 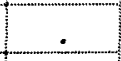 \\
\hline ALQUIL FENOL ETER POLIOXIETILENO & $\mathrm{O}$ & $Y$ & Y & & . & \\
\hline ALQUIL-FENOL-POLIGLICOLETER & 0 & Y & $\bar{Y}$ & & & \\
\hline AMETRINA & $\mathrm{H}$ & Y & Y & III & III & III \\
\hline AMINA GRAXA ETOXILADA & 0 & $\mathrm{Y}$ & $\mathrm{Y}$ & & & \\
\hline AMITRAZ & 1 & $\mathrm{~N}$ & $\mathrm{Y}$ & & III & III \\
\hline ANIDRO NAFTALICO & 0 & $N$ & $\mathrm{Y}$ & $U$ & 0 & III \\
\hline ANILAZINE & $F$ & $\mathrm{Y}$ & $\mathrm{Y}$ & $u$ & 0 & III \\
\hline ASULAM & $\mathrm{H}$ & $\mathrm{Y}$ & $\mathrm{Y}$ & $U$ & $\mathrm{U}$ & III \\
\hline ATRAZINE & $\mathrm{H}$ & $\mathrm{Y}$ & $\mathrm{Y}$ & $u$ & $u$ & III \\
\hline AZINPHOS ETHYL & $\mathrm{I}$ & $\mathrm{Y}$ & $\mathrm{Y}$ & $\mathrm{Ib}$ & $\mathrm{Ib}$ & $\mathrm{I}$ \\
\hline AZOCYCLOTIN & 1 & $\mathrm{~N}$ & $\mathrm{Y}$ &. & II & 1 \\
\hline AZOXYSTROBIN & $F$ & $\mathrm{~N}$ & Y & . & $U$ & III \\
\hline BACILLUS THURINGIENSIS & 1 & Y & Y &. &. & IV \\
\hline BACULOVIRUS ANTICARSIA & 1 & $\mathrm{~N}$ & Y & . & . & IV \\
\hline BENFURACARB & 1 & $\mathrm{~N}$ & $Y$ & & II & II \\
\hline BENOMYL & $F$ & Y & Y & $U$ & $\mathrm{U}$ & III \\
\hline BENTAZONE & $\mathrm{H}$ & Y & Y & III & III & III \\
\hline BETACYFLUTRIN & 1 & $N$ & $\mathrm{Y}$ & & II & II \\
\hline BIFENOX & $\mathrm{H}$ & Y & Y & $U$ & $\mathrm{U}$ & III \\
\hline BIFENTHRIN & 1 & Y & $Y$ & II & II & II \\
\hline BINAPACRIL & 1 & Y & Y & II & $\mathrm{O}$ & II \\
\hline BISPYRIBAC-SODIUM & $\mathrm{H}$ & $\mathrm{N}$ & Y & . & $\mathrm{U}$ & III \\
\hline BITERTANOL & $F$ & Y & Y & $U$ & $\mathrm{U}$ & III \\
\hline BROMACIL & $\mathrm{H}$ & $Y$ & Y & $u$ & U & III \\
\hline BROMETO DE METILA & 1 & $Y$ & $Y$ & $F$ & $F$ & 1 \\
\hline BROMOFOS & 1 & Y & $Y$ & III & 0 & 11 \\
\hline BROMOFOS ETILICO & 1 & Y & Y & $\mathrm{Ib}$ & 0 & 1 \\
\hline BROMOPROPYLATE & 1 & $Y$ & $Y$ & $U$ & $U$ & III \\
\hline BROMOXINIL & $\mathrm{H}$ & $Y$ & $Y$ & II & 11 & II \\
\hline BROMUCONAZOLE & $F$ & $\mathrm{~N}$ & Y & . & II & III \\
\hline BUPROFENZIN & 1 & $\mathrm{~N}$ & $Y$ &. & U & IV \\
\hline BUTACHLOR & $\mathrm{H}$ & $Y$ & $Y$ & U & $\mathrm{U}$ & III \\
\hline
\end{tabular}


(continuação do Anexo I)

\begin{tabular}{|c|c|c|c|c|c|c|}
\hline INGREDIENTES ATIVOS & USO & 1990 & 2000 & OMS90 & OMS98 & CTMS \\
\hline BUTRALIN & $\mathrm{H}$ & Y & Y & $U$ & $U$ & II \\
\hline BUTROXYDIM & $\mathrm{H}$ & $\mathrm{N}$ & $\mathrm{Y}$ & & III & IV \\
\hline BUTYLATE & $\mathrm{H}$ & $\mathrm{Y}$ & $\mathrm{Y}$ & $\mathrm{U}$ & $\mathrm{U}$ & III \\
\hline CALDA BORDALEZA & $F$ & Y & $Y$ & & & IV \\
\hline CAPTAN & $F$ & $Y$ & Y & U & $U$ & IV \\
\hline CARBARYL & 1 & $Y$ & $\mathrm{Y}$ & II & II & II \\
\hline CARBENDAZIM & $F$ & $Y$ & Y & $\mathrm{U}$ & U & III \\
\hline CARBOFENOTION & 1 & $Y$ & $Y$ & Ib & 0 & 1 \\
\hline CARBOFURAN & 1 & $Y$ & Y & $\mathrm{Ib}$ & $\mathrm{lb}$ & 1 \\
\hline CARBOSULFAN & 1 & $Y$ & $Y$ & II & II & II \\
\hline CARBOXIN & $F$ & $Y$ & Y & $U$ & $\mathrm{U}$ & III \\
\hline CARTAP, CLORIDRATO & 1 & Y & Y & 11 & II & III \\
\hline CHLORFENAPYR & 1 & $\mathrm{~N}$ & $Y$ & & II & II \\
\hline CHLORFENVINPHOS & 1 & Y & Y & la & Ib & 1 \\
\hline CHLORIMURON ETHYL & $\mathrm{H}$ & $Y$ & Y & & $\mathrm{U}$ & III \\
\hline CHLORMEQUAT & 0 & $Y$ & $Y$ & III & III & III \\
\hline CHLORTHAL DIMETHYL & $\mathrm{H}$ & $\mathrm{N}$ & $Y$ & . & $u$ & III \\
\hline CIPRODINIL & $F$ & $\mathrm{~N}$ & $Y$ & $\cdot$ & $\cdot$ & III \\
\hline CLEFOXYDIM & $\mathrm{H}$ & $N$ & Y &. & . & IV \\
\hline CLETHODIM & $\mathrm{H}$ & $\mathrm{N}$ & $Y$ & . & 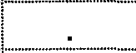 & II \\
\hline CLOFENTEZINE & 1 & $Y$ & $Y$ & $u$ & $u$ & III \\
\hline CLOMAZONE (EX-FENOXAN) & $\mathrm{H}$ & Y & Y & . & II & III \\
\hline CLOR.DEALQUIL DIM.BENZ.AMONEA & $F$ & $N$ & Y & & & \\
\hline CLORAMBEM & $\mathrm{H}$ & Y & Y & $U$ & $U$ & III \\
\hline CLORANSULAM METIL & $\mathrm{H}$ & $N$ & $Y$ & . & $\mathrm{U}$ & \\
\hline CLORETO DE MEPIQUAT & 0 & $N$ & Y & 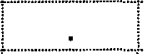 & III & III \\
\hline CLORFLUAZURON & 1 & $\mathrm{~N}$ & $Y$ & 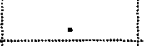 & $U$ & IV \\
\hline CLOROBENZILATO & 1 & $Y$ & $N$ & III & 0 & II \\
\hline CLOROPICRINA & 1 & Y & Y & $F$ & $\mathrm{~F}$ & \\
\hline CLOROTHALONIL & $\mathrm{F}$ & Y & $Y$ & $U$ & $U$ & III \\
\hline CLORPYRIFOS & 1 & Y & Y & II & II & II \\
\hline COBRE, HIDROXIDO DE & $F$ & Y & Y & & III & IV \\
\hline COBRE, OXICLORETO DE & $F$ & Y & Y & III & III & IV \\
\hline COPOLIM.MONOM.ACRIL+DIOCTIL SU & 0 & $\mathrm{~N}$ & Y & . & . & \\
\hline COPOLIMERO DE POLIETER E SILIC & 0 & $N$ & Y & 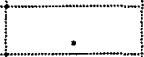 & . & \\
\hline CYANAMIDE & 0 & N & Y & . & . & 1 \\
\hline CYANAZINE & $H$ & $Y$ & Y & II & II & II \\
\hline CYCLANILIDE & 0 & $N$ & Y & . & . & 1 \\
\hline CYCLOSULFAMURON & $\mathrm{H}$ & $N$ & Y & 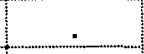 & U & III \\
\hline CYFLUTHRIN & 1 & $\mathrm{Y}$ & $Y$ & II & 11 & 11 \\
\hline CYHEXATIN & 1 & Y & $Y$ & III & III & III \\
\hline
\end{tabular}


(continuação do Anexo I)

\begin{tabular}{|c|c|c|c|c|c|c|}
\hline INGREDIENTES ATIVOS & USO & 1990 & 2000 & OMS90 & OMS98 & CTMS \\
\hline CYMOXANIL & $F$ & $Y$ & $Y$ & III & III & III \\
\hline CYPERMETHRIN & 1 & $Y$ & $Y$ & II & II & II \\
\hline CYPROCONAZOLE & $F$ & $N$ & $Y$ & & III & IIII \\
\hline CYROMAZINE & 1 & $Y$ & Y & U & $U$ & IV \\
\hline DALAPON & $\mathrm{H}$ & Y & $Y$ & $\mathrm{U}$ & $U$ & III \\
\hline DAMINOZIDE & 0 & $N$ & $Y$ & & $U$ & IV \\
\hline DAZOMET & $\mathrm{F}$ & $\mathrm{N}$ & $Y$ & & III & III \\
\hline DECANOL & 0 & Y & Y & & & III \\
\hline DELTAMETHRINE & 1 & $Y$ & Y & II & II & III \\
\hline DEMETON-S-METIL & 1 & $Y$ & Y & $\mathrm{lb}$ & $\mathrm{Ib}$ & 1 \\
\hline DIAFENTIURON & 1 & $N$ & Y & & $U$ & III \\
\hline DIAZINON & 1 & Y & Y & II & II & 11 \\
\hline DICAMBA & $\mathrm{H}$ & Y & Y & U & III & III \\
\hline DICLOBENIL & $\mathrm{H}$ & $Y$ & $Y$ & U & $\mathrm{U}$ & III \\
\hline DICLOFOP-METHIL & $\mathrm{H}$ & Y & Y & III & III & III \\
\hline DICLORAN & $\mathrm{F}$ & $\mathrm{Y}$ & $\mathrm{Y}$ & $\mathrm{U}$ & $U$ & III \\
\hline DICLORVOS (DDVP) & 1 & $Y$ & $\mathrm{Y}$ & Ib & $\mathrm{lb}$ & 11 \\
\hline DICLOSULAM & $\mathrm{H}$ & $N$ & Y & & $U$ & III \\
\hline DICOFOL & I & $\mathrm{Y}$ & Y & III & III & II \\
\hline DICROTOFOS & 1 & $Y$ & $Y$ & Ib & Ib & 1 \\
\hline DIFENAMIDA & $\mathrm{H}$ & Y & Y & la & III & III \\
\hline DIFENOCONAZOLE & $F$ & $\mathrm{~N}$ & Y & 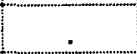 & III & III \\
\hline DIFLUBENZURON & 1 & $Y$ & Y & $U$ & U & IV \\
\hline DIMETHENAMID & $\mathrm{H}$ & $N$ & $Y$ & . & . & IV \\
\hline DIMETHOMORPH & $F$ & $\mathrm{~N}$ & Y & - & $U$ & III \\
\hline DIMETOATO & 1 & $\mathrm{Y}$ & $Y$ & II & II & II \\
\hline DINICONAZOLE & $\mathrm{F}$ & $Y$ & $\mathrm{Y}$ & 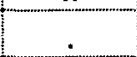 & III & \\
\hline DINOCAP & 1 & N & $Y$ & & III & II \\
\hline DIOXIDO DE SILICA & 1 & $\bar{N}$ & $Y$ & & . & . \\
\hline DIQUAT & $\mathrm{H}$ & $Y$ & $\mathrm{Y}$ & II & II & II \\
\hline DISULFOTON & 1 & $Y$ & $\mathrm{Y}$ & la & la & 1 \\
\hline DITHIANON & $F$ & $Y$ & $\mathrm{Y}$ & III & III & 11 \\
\hline DIURON & $\mathrm{H}$ & $Y$ & $\mathrm{Y}$ & $U$ & $U$ & III \\
\hline DODECACLORO OCTAHIDRO (MIREX) & 1 & $Y$ & $N$ & 0 & 0 & \\
\hline DODECILBENZENOSULFONICO & 0 & Y & Y & & & \\
\hline DODINE & $\mathrm{F}$ & Y & Y & III & III & III \\
\hline EDIFENPHOS & $\mathrm{F}$ & Y & $\mathrm{Y}$ & $\mathrm{lb}$ & lb & II \\
\hline ENDOSULFAN & 1 & $Y$ & Y & 11 & II & 1 \\
\hline ENXOFRE & $F$ & Y & Y & $U$ & $U$ & IV \\
\hline EPOXICONAZOLE & $\mathrm{F}$ & $\mathrm{N}$ & Y & & . & III \\
\hline EPTC (S-ETIL-DIPROPIL) (TIOCARBAMATO) & $\mathrm{H}$ & $Y$ & $Y$ & II & II & II \\
\hline
\end{tabular}


(continuação do Anexo I)

\begin{tabular}{|c|c|c|c|c|c|c|}
\hline INGREDIENTES ATIVOS & USO & 1990 & 2000 & OMS90 & OMS98 & CTMS \\
\hline ESFENVALERATE & 1 & $\mathrm{~N}$ & $\mathrm{Y}$ & . & II & II \\
\hline ESTERES METILICOS,HIDROCARBONE & 0 & $\mathrm{~N}$ & Y & 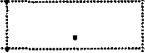 & & \\
\hline ESTREPTOMICINA, SULFATO DE & $\mathrm{F}$ & Y & $Y$ & $\cdot$ & $\cdot$ & II \\
\hline ETENO, OXIDO DE & 0 & $Y$ & Y & $\therefore$ & 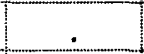 & \\
\hline ETER POLIGLICOLICO AROMATICO & 0 & $\bar{Y}$ & Y & . & . & \\
\hline ETER POLIGLICOLICO DE NONILFENOL & 0 & Y & Y & 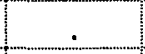 & me & \\
\hline ETHEPHON & 0 & $Y$ & $Y$ & $U$ & $U$ & III \\
\hline ETHION & 1 & $Y$ & $Y$ & II & 11 & 11 \\
\hline ETHOXYSULFURON & $H$ & $\mathrm{~N}$ & Y & & $\because$ & III \\
\hline ETIL-TRINEXAPAC & 0 & $N$ & $Y$ &. & . & IV \\
\hline ETOFENPROX & 1 & $N$ & $Y$ & 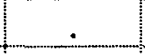 & $\underline{U}$ & IV \\
\hline ETOPROPHOS & 1 & $Y$ & $\mathrm{Y}$ & la & la & 1 \\
\hline ETRIDIAZOLE & $\mathrm{F}$ & $Y$ & $Y$ & III & III & III \\
\hline FAMOXADONE & $F$ & $\mathrm{~N}$ & $Y$ & & & III \\
\hline FENAMIPHOS & 1 & $\mathrm{Y}$ & Y & la & la & 1 \\
\hline FENARIMOL & $F$ & $Y$ & $Y$ & $u$ & $U$ & III \\
\hline FENBUTATIN OXIDE & 1 & $Y$ & $Y$ & $U$ & $\mathrm{U}$ & III \\
\hline FENITROTHION & 1 & $Y$ & Y & II & II & 11 \\
\hline FENOXAPROP-ETHIL & $\mathrm{H}$ & $Y$ & $Y$ & $\underline{U}$ & 0 & 11 \\
\hline FENOXAPROP-P-ETIL & $\mathrm{H}$ & $\mathrm{Y}$ & $\mathrm{Y}$ & & & II \\
\hline FENPROPATHRIN & 1 & $\mathrm{Y}$ & $\mathrm{Y}$ & II & II & 11 \\
\hline FENPROPIMORPH & $F$ & $\mathrm{~N}$ & $Y$ & . & U & II \\
\hline FENPYROXIMATE & 1 & $\mathrm{~N}$ & $Y$ & . & & II \\
\hline FENSULFOTION & 1 & $Y$ & $Y$ & la & 0 & 1 \\
\hline FENTHION & 1 & $Y$ & $Y$ & lb & II & II \\
\hline FENTIN ACETATO & $F$ & $Y$ & $Y$ & 11 & II & \\
\hline FENTIN HIDROXIDE & $\mathrm{F}$ & $Y$ & $Y$ & II & II & \\
\hline FENTOATO & 1 & $\mathrm{~N}$ & $Y$ & & II & III \\
\hline FENVALERATE & 1 & $Y$ & $Y$ & II & II & II \\
\hline FIPRONIL & 1 & $N$ & $Y$ & . & II & II \\
\hline FLAZASULFURON & $\mathrm{H}$ & $\mathrm{N}$ & $Y$ &. & & III \\
\hline FLUAZIFOP-P-BUTIL & $\mathrm{H}$ & $Y$ & $Y$ & . & III & III \\
\hline FLUAZINAM & $F$ & $\mathrm{~N}$ & $Y$ & & & 1 \\
\hline FLUCYTHRINATE & 1 & $Y$ & $Y$ & $\mathrm{lb}$ & $\mathrm{Ib}$ & 1 \\
\hline FLUDIOXONIL & $F$ & $N$ & Y & & & III \\
\hline FLUFENOXURON & 1 & $\mathrm{~N}$ & Y & . & $\mathrm{U}$ & IV \\
\hline FLUMETRALIN & 0 & $Y$ & $Y$ & u & $\mathrm{u}$ & IV \\
\hline FLUMETSULAN & $\mathrm{H}$ & $\mathrm{N}$ & $Y$ & . & $\mathrm{U}$ & IV \\
\hline FLUMICLORAC-PENTIL & $\mathrm{H}$ & $N$ & $Y$ & . &. & IV \\
\hline FLUMIOXAZIN & $H$ & $N$ & Y & & & IV \\
\hline FLUQUINCONAZOLE & $F$ & $\mathrm{~N}$ & $Y$ & & & III \\
\hline
\end{tabular}


(continuação do Anexo I)

\begin{tabular}{|c|c|c|c|c|c|c|}
\hline INGREDIENTES ATIVOS & USO & 1990 & 2000 & OMS90 & OMS98 & CTMS \\
\hline FLUROXIPIR MHE & $H$ & $N$ & $y$ & & 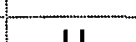 & III \\
\hline FLUTRIAFOL & $\frac{H}{F}$ & $\frac{N}{N}$ & $\frac{Y}{Y}$ & . & III & IIII \\
\hline FLUVALINATE & 1 & Y & $\mathrm{Y}$ & II & 0 & II \\
\hline FOLPET & $F$ & Y & $Y$ & $U$ & $U$ & IV \\
\hline FOMESAFEN & $\mathrm{H}$ & Y & Y & III & III & III \\
\hline FORMETANATE HIDROCLORETO & 1 & $\mathrm{~N}$ & $\bar{Y}$ & & $\mathrm{Ib}$ & 11 \\
\hline FORMOTHION & 1 & $Y$ & Y & II & II & II \\
\hline FOSETYL-AL & $\mathrm{F}$ & Y & $\mathrm{Y}$ & & & III \\
\hline FOSFINA E FOSFETOS METALICOS & 1 & $Y$ & Y & $F$ & $F$ & 1 \\
\hline FOSTHIAZATE & 1 & $N$ & Y & & & II \\
\hline FTALIDE & $F$ & $\mathrm{Y}$ & Y & $u$ & $\mathrm{U}$ & IV \\
\hline FURATHIOCARB & 1 & Y & Y & Ib & $\mathrm{Ib}$ & II \\
\hline GLUFOSINATO DE AMONIO & $\mathrm{H}$ & $N$ & Y & . & III & III \\
\hline GLYPHOSATE & $\mathrm{H}$ & $Y$ & $Y$ & $\mathrm{U}$ & $U$ & IV \\
\hline GRANDLURE & 1 & $\mathrm{~N}$ & Y & . & 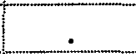 & II \\
\hline GUAZATINE & $\mathrm{F}$ & $N$ & Y & . & II & II \\
\hline HALOSULFURON & $\mathrm{H}$ & $\mathrm{N}$ & $\mathrm{Y}$ & & & IV \\
\hline HALOXYFOP METHYL & $\mathrm{H}$ & $Y$ & $\mathrm{Y}$ & II & II & III \\
\hline HALOXYFOP-R, ESTER METILICO & $\mathrm{H}$ & $\mathrm{N}$ & $Y$ & . & - & III \\
\hline HEXACONAZOLE & $F$ & $\mathrm{~N}$ & $Y$ & & $U$ & III \\
\hline HEXAZINONE & $\mathrm{H}$ & $Y$ & $Y$ & III & III & III \\
\hline HEXYTHIAZOX & 1 & $Y$ & $\mathrm{Y}$ & $\mathrm{U}$ & $\mathrm{U}$ & IIII \\
\hline HIDRAZINA MALEICA & 0 & $Y$ & $Y$ & $\mathrm{U}$ & $\mathbf{U}$ & IV \\
\hline IBP & $\mathrm{F}$ & Y & $Y$ & III & III & II \\
\hline IMAZALIL & $F$ & $\mathrm{~N}$ & $Y$ & II & II & III \\
\hline IMAZAMOX & $\mathrm{H}$ & $\mathrm{N}$ & $Y$ &. & . & II \\
\hline IMAZAPIC & $H$ & $\mathrm{~N}$ & $Y$ & & & II \\
\hline IMAZAPYR & $H$ & $Y$ & Y & $\mathrm{U}$ & U & III \\
\hline IMAZAQUIM & $\mathrm{H}$ & $Y$ & $Y$ & $U$ & $\mathrm{U}$ & III \\
\hline IMAZETHAPYR & $\mathrm{H}$ & N & Y & & $\mathrm{U}$ & III \\
\hline IMIBENCONAZOLE & $F$ & $N$ & $Y$ & . & U & IV \\
\hline IMIDACLOPRID & 1 & $N$ & $Y$ & 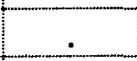 & II & III \\
\hline OXYNIL & $H$ & $Y$ & $\bar{Y}$ & 11 & II & II \\
\hline IPRODIONE & $F$ & $Y$ & $Y$ & $\mathrm{U}$ & $\mathrm{U}$ & IV \\
\hline ISODECANOL & 0 & $\mathrm{~N}$ & Y & . & . & III \\
\hline ISOPROCARB & 1 & Y & $Y$ & II & II & II \\
\hline ISOURON & $\mathrm{H}$ & $N$ & Y & . & III & III \\
\hline ISOXAFLUTOLE & $\mathrm{H}$ & $N$ & $Y$ & & & III \\
\hline KASUGAMICINA, CLORIDRATO DE & $F$ & $Y$ & $Y$ & U & U & \\
\hline KRESOXIM-METHYL & $\mathrm{F}$ & $\mathrm{N}$ & $Y$ & & & IIII \\
\hline LACTOFEN & $H$ & $Y$ & Y & & & III \\
\hline
\end{tabular}


(continuação do Anexo I)

\begin{tabular}{|c|c|c|c|c|c|c|}
\hline INGREDIENTES ATIVOS & USO & 1990 & 2000 & OMS90 & OMS98 & CTMS \\
\hline LAMBDACYHALOTHRIN & 1 & $Y$ & $\mathrm{Y}$ & . & 11 & III \\
\hline LAURIL ETER SULFATO DE SODIO & 0 & $\mathrm{~N}$ & $\mathrm{Y}$ & & & \\
\hline LINURON & $\mathrm{H}$ & $Y$ & Y & $U$ & $U$ & III \\
\hline LUFENURON & 1 & $\mathrm{~N}$ & $\mathrm{Y}$ & & & III \\
\hline M.C.P.A. & $\mathrm{H}$ & Y & Y & III & III & III \\
\hline MALATHION & 1 & Y & Y & III & III & III \\
\hline MANCOZEB & $\mathrm{F}$ & $\mathrm{Y}$ & $\mathrm{Y}$ & u & U & III \\
\hline MANEB & $F$ & $Y$ & $Y$ & $\mathrm{U}$ & $\mathrm{U}$ & III \\
\hline METALAXYL & $F$ & Y & Y & III & III & III \\
\hline METALAXYL-M & $F$ & $\mathrm{~N}$ & $Y$ & & & II \\
\hline METALDEIDO & 1 & $\mathrm{Y}$ & Y & III & II & III \\
\hline METAM SODIUM & 1 & $N$ & $Y$ & & II & II \\
\hline METHAMIDOPHOS & 1 & $Y$ & $Y$ & $\mathrm{Ib}$ & $\mathrm{Ib}$ & 1 \\
\hline METHIDATHION & 1 & $\mathrm{Y}$ & $\mathrm{Y}$ & Ib & Ib & II \\
\hline METHIOCARB & 1 & $N$ & $Y$ & & II & II \\
\hline METHOPRENE & 1 & $Y$ & $Y$ & $U$ & $U$ & III \\
\hline METHOXYFENOZIDE & 1 & $\mathbf{N}$ & $Y$ & . & . & IV \\
\hline METOLACLOR & $\mathrm{H}$ & $Y$ & Y & III & III & III \\
\hline METOMYL & 1 & $Y$ & $Y$ & $\mathrm{Ib}$ & $\mathrm{Ib}$ & 1 \\
\hline METRIBUZIN & $\mathrm{H}$ & $\mathrm{Y}$ & $\mathrm{Y}$ & $\mathrm{U}$ & $\mathrm{U}$ & III \\
\hline METSULFURON METHYL & $\mathrm{H}$ & $\mathrm{N}$ & $\mathrm{Y}$ & . & . & III \\
\hline MEVINPHOS & 1 & $Y$ & $\mathrm{Y}$ & la & la & 1 \\
\hline MOLINATE & $\mathrm{H}$ & $Y$ & Y & II & II & II \\
\hline MONOCROTOPHOS & 1 & $Y$ & $Y$ & lb & Ib & 1 \\
\hline MSMA & $\mathrm{H}$ & $Y$ & Y & III & III & II \\
\hline MULTIMETIL ALQUENOL & 0 & $Y$ & Y & . &. & . \\
\hline MYCLOBUTANIL & $F$ & $\mathrm{~N}$ & $Y$ & . & III & 1 \\
\hline NALED & 1 & $Y$ & Y & II & II & III \\
\hline NAPROPAMIDA & $\mathrm{H}$ & $Y$ & Y & 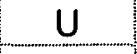 & $U$ & III \\
\hline NAPTALAM & $\mathrm{H}$ & Y & Y & 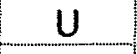 & $\underline{U}$ & II \\
\hline N-DECANOL & 0 & $Y$ & $Y$ & . & 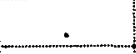 & IV \\
\hline NICOSULFURON & $\mathrm{H}$ & $\mathrm{N}$ & Y & . & U & III \\
\hline NON.FENOL POLI ETAN+SAL AC DOD & 0 & $\mathrm{~N}$ & Y & $-\therefore$ &. & 5 \\
\hline NONIL FENOXI POLI (ETILENOXI) ETANOL & 0 & $Y$ & $Y$ & & & \\
\hline NONILFENOL & 0 & $N$ & Y & &. & \\
\hline NONILFENOL ETOXILADO & 0 & $Y$ & Y & . & . & \\
\hline NONILFENOL OXIETILADO & 0 & Y & Y & 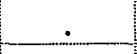 & 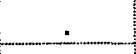 & 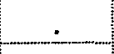 \\
\hline NONILFENOL POLIETILENO GLICOL ETER & 0 & $Y$ & Y & 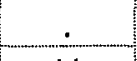 &. & \\
\hline NORFLURAZON & $\mathrm{H}$ & $Y$ & Y & $u$ & $\mathrm{U}$ & IV \\
\hline OLEO MINERAL & 1 & $Y$ & $Y$ & & & IV \\
\hline OLEO VEGETAL & 1 & $\mathrm{~N}$ & Y & & & IV \\
\hline
\end{tabular}


(continuação do Anexo I)

\begin{tabular}{|c|c|c|c|c|c|c|}
\hline INGREDIENTES ATIVOS & USO & 1990 & 2000 & OMS90 & OMS98 & CTMS \\
\hline OMETHOATE & 1 & $Y$ & $Y$ & $\mathrm{Ib}$ & $\mathrm{Ib}$ & 1 \\
\hline ORYZALINA & $\mathrm{H}$ & $Y$ & $Y$ & $\mathrm{U}$ & $u$ & III \\
\hline OXADIAZON & $\mathrm{H}$ & $Y$ & $Y$ & U & $U$ & III \\
\hline OXADIXIL & $F$ & $\mathrm{~N}$ & $Y$ & & III & IV \\
\hline OXAMIL & 1 & Y & $Y$ & $\mathrm{Ib}$ & $\mathrm{lb}$ & 1 \\
\hline OXASULFURON & $\mathrm{H}$ & $\mathrm{N}$ & $Y$ &. & & IV \\
\hline OXIDO CUPROSO & $F$ & $Y$ & $Y$ &. & 11 & IV \\
\hline OXITETRACICLINA & $F$ & Y & Y & 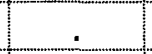 & & II \\
\hline OXYCARBOXIN & $F$ & $Y$ & $Y$ & $\mathrm{U}$ & $U$ & III \\
\hline OXYFLUORFEN & $\mathrm{H}$ & Y & $Y$ & $\mathrm{U}$ & $U$ & III \\
\hline PARAQUAT DICLORETO & $\mathrm{H}$ & Y & $Y$ & II & II & 1 \\
\hline PARATHION METIL & 1 & Y & $Y$ & la & la & 1 \\
\hline PARATION & 1 & $Y$ & $Y$ & la & la & 1 \\
\hline PEBULATE & $\mathrm{H}$ & Y & $Y$ & II & II & III \\
\hline PENCYCURON & $F$ & $N$ & $Y$ & & $U$ & IV \\
\hline PENDIMETHALIN & $\mathrm{H}$ & Y & $Y$ & III & III & III \\
\hline PERMETHRIN & 1 & $Y$ & $Y$ & II & 11 & III \\
\hline PHORATE & 1 & Y & $Y$ & la & la & 1 \\
\hline PHOSALONE & 1 & $Y$ & $Y$ & II & II & II \\
\hline PHOSMET & 1 & $Y$ & $Y$ & 11 & II & II \\
\hline PHOSPHAMIDON & 1 & Y & $Y$ & la & la & 1 \\
\hline PHOSTEBUPIRIM & 1 & $N$ & $Y$ & & . & 1 \\
\hline PICLORAM & $\mathrm{H}$ & $Y$ & $\bar{Y}$ & $U$ & $\mathrm{U}$ & III \\
\hline PIRACARBOLIDE & $\mathrm{F}$ & $Y$ & $Y$ & $\mathrm{U}$ & 0 & III \\
\hline PIRAZOSULFURON - ETIL & $\mathrm{H}$ & $\mathrm{N}$ & $Y$ & & $u$ & III \\
\hline PIRIMICARB & 1 & Y & $Y$ & 11 & II & II \\
\hline PIRIMIFOS METHYL & 1 & $Y$ & $Y$ & III & III & III \\
\hline POLI OXIETILENO ALQUIL FENOLE & 0 & $N$ & Y & & 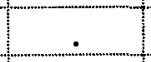 & 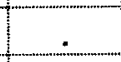 \\
\hline POLIETER & 0 & $\mathrm{~N}$ & $Y$ & & 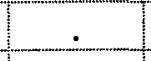 &. \\
\hline PROCHLORAZ & $\mathrm{F}$ & $\mathrm{N}$ & $Y$ & & III & 1 \\
\hline PROCIMIDONE & $F$ & $N$ & $Y$ & & 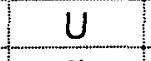 & IV \\
\hline PROFENOFOS & 1 & $Y$ & $Y$ & 11 & 11 & 11 \\
\hline PROMETON & $\mathrm{H}$ & $Y$ & $Y$ & $u$ & $\mathrm{U}$ & III \\
\hline PROMETRYNE & $\mathrm{H}$ & $Y$ & Y & U & U & III \\
\hline PROPAMOCARB HYDROCHLORIDE & $\mathrm{F}$ & $Y$ & $Y$ & & $\mathrm{U}$ & III \\
\hline PROPANIL & $\mathrm{H}$ & Y & $\bar{Y}$ & III & III & III \\
\hline PROPAQUIZAFOP & $\mathrm{H}$ & $\mathrm{N}$ & $Y$ & & $U$ & III \\
\hline PROPARGITE & 1 & $Y$ & Y & III & III & III \\
\hline PROPICONAZOLE & $F$ & Y & $Y$ & II & II & II \\
\hline PROPOXUR & 1 & $Y$ & $Y$ & II & II & II \\
\hline PROTHIOFOS & 1 & $N$ & $\mathrm{Y}$ & - & II & II \\
\hline
\end{tabular}


(continuação do Anexo I)

\begin{tabular}{|c|c|c|c|c|c|c|}
\hline INGREDIENTES ATIVOS & USO & 1990 & 2000 & OMS90 & OMS98 & CTMS \\
\hline PYRAZOPHOS & $\mathrm{F}$ & Y & $Y$ & II & II & II \\
\hline PYRIDABEN & 1 & $N$ & Y & . & III & II \\
\hline PYRIDAPHENTHION & 1 & $\mathrm{~N}$ & Y & & III & IV \\
\hline PYRIDATE & $H$ & $\mathrm{~N}$ & Y & . & III & III \\
\hline PYRIFENOX & $F$ & $\mathrm{~N}$ & $Y$ & . & III & II \\
\hline PYRIMETHANIL & $F$ & $N$ & Y & . & $\mathrm{U}$ & III \\
\hline PYRIPROXIFEN & 1 & $N$ & $Y$ & . & U & III \\
\hline PYRITHIOBAC-SODIUM & $\mathrm{H}$ & $\mathrm{N}$ & $Y$ &. & $\mathrm{U}$ & III \\
\hline PYROQUILON & $\mathrm{F}$ & $Y$ & $\mathrm{Y}$ & II & II & III \\
\hline QUINCLORAC & $\mathrm{H}$ & Y & $Y$ & & $U$ & III \\
\hline QUINOMETIONATO & 1 & $Y$ & Y & $\mathrm{U}$ & $\mathrm{U}$ & III \\
\hline QUINTOZENE & $F$ & $\mathrm{Y}$ & $\mathrm{Y}$ & $\mathrm{U}$ & $u$ & III \\
\hline QUIZALOFOP-P-ETHYL & $\mathrm{H}$ & $\mathrm{N}$ & $Y$ & & III & III \\
\hline QUIZALOFOP-P-TEFURIL & $\mathrm{H}$ & $\mathrm{N}$ & $Y$ & & II & III \\
\hline RESINA SINTETICA EMULSIONADA & 0 & $Y$ & Y & & & \\
\hline SERRICORNIN & 1 & $N$ & Y & & & III \\
\hline SETHOXYDIM & $\mathrm{H}$ & Y & Y & III & III & III \\
\hline SIMAZINE & $\mathrm{H}$ & $Y$ & Y & $\mathrm{U}$ & $\mathrm{U}$ & III \\
\hline S-METOLACHLOR & $\mathrm{H}$ & $N$ & Y & . & (at & \\
\hline SPINOSAD & 1 & $\mathrm{~N}$ & Y & . & $U$ & III \\
\hline SULFENTRAZONE & $\mathrm{H}$ & $N$ & $Y$ & . & & III \\
\hline SULFLURAMIDA & 1 & $N$ & Y & . & III & IV \\
\hline SULFOMETURON METIL & $\mathrm{H}$ & $N$ & Y & . & $u$ & . \\
\hline SULFONATOS ORGANICOS & 0 & $Y$ & $\mathrm{Y}$ & . & . & . \\
\hline SULFOPROS & 1 & $\mathrm{Y}$ & $Y$ & II & II & II \\
\hline SULFOSATE & $\mathrm{H}$ & $N$ & Y & 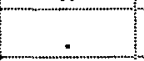 & 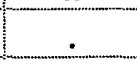 & III \\
\hline TEBUCONAZOLE & $\mathrm{F}$ & $Y$ & $Y$ &. & $u$ & IV \\
\hline TEBUFENOZIDE & 1 & $N$ & $Y$ & & -3 & IV \\
\hline TEBUTHIURON & $\mathrm{H}$ & $Y$ & Y & III & III & II \\
\hline TEFLUBENZURON & 1 & $\mathrm{~N}$ & $Y$ & 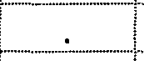 & $U$ & IV \\
\hline TERBACIL & $\mathrm{H}$ & $Y$ & Y & $U$ & $\mathrm{U}$ & III \\
\hline TERBUFOS & 1 & $N$ & $Y$ & 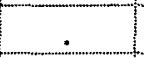 & la & 1 \\
\hline TERBUTILAZINA & $\mathrm{H}$ & $Y$ & $Y$ & U & $U$ & III \\
\hline TERRA DIATOMACEA & 1 & $N$ & $Y$ &. & 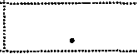 & III \\
\hline TERRAMICINA & $\mathrm{F}$ & $\mathrm{N}$ & Y & & . & $\cdot$ \\
\hline TETRACONAZOLE & $F$ & $N$ & Y & . & 11 & \\
\hline TETRADIFON & 1 & $Y$ & Y & U & $U$ & IV \\
\hline THIABENDAZOLE & $F$ & $\mathrm{Y}$ & $\mathrm{Y}$ & $\mathrm{U}$ & $U$ & IV \\
\hline THIAMETHOXAM & 1 & $\mathrm{~N}$ & $Y$ & - & . & \\
\hline THIAZOPYR & $\mathrm{H}$ & $N$ & Y & & & III \\
\hline THIDIAZURON & $\mathrm{H}$ & $\mathrm{N}$ & $Y$ & & $U$ & IV \\
\hline
\end{tabular}


(final do Anexo I)

\begin{tabular}{|c|c|c|c|c|c|c|}
\hline INGREDIENTES ATIVOS & USO & 1990 & 2000 & OMS90 & OMS98 & CTMS \\
\hline THIOBENCARB & $\mathrm{H}$ & $\mathrm{Y}$ & $\mathrm{Y}$ & II & II & IIII \\
\hline THIODICARB & 1 & $\mathrm{Y}$ & $\mathrm{Y}$ & II & II & II \\
\hline THIOMETON & 1 & $\mathrm{Y}$ & $\mathrm{Y}$ & Ib & Ib & II \\
\hline THIRAM & $F$ & $Y$ & Y & III & III & II \\
\hline TIAMINA & 0 & $\mathbf{N}$ & $Y$ & . & & IV \\
\hline TIOFANATO METILICO & $\mathrm{F}$ & $Y$ & Y & $U$ & U & IV \\
\hline TOLCLOFOS METIL & $F$ & $N$ & Y & $U$ & $\mathrm{U}$ & IV \\
\hline TOLYLFLUANID & $F$ & $\mathbf{N}$ & Y & & $U$ & 1 \\
\hline TRIADIMEFON & $F$ & $Y$ & Y & III & III & III \\
\hline TRIADIMENOL & $\mathrm{F}$ & Y & Y & III & III & III \\
\hline TRIAZOPHOS & 1 & $Y$ & Y & $\mathrm{Ib}$ & $\mathrm{Ib}$ & II \\
\hline TRICICLOHEXIL ESTANHO & 1 & Y & $Y$ & mes &. & . \\
\hline TRICLOPYR (ESTER BUTOXI ETILICO) & $\mathrm{H}$ & Y & Y & III & III & III \\
\hline TRICLORFON & 1 & Y & Y & III & III & II \\
\hline TRICYCLAZOLE & $F$ & Y & Y & II & II & II \\
\hline TRIDEMORPH & $F$ & Y & Y & II & II & III \\
\hline TRIFENIL ACETATO DE ESTANHO & $\mathrm{F}$ & Y & $\mathrm{Y}$ &. &. & II \\
\hline TRIFENIL HIDROXIDO DE ESTANHO & $\mathrm{F}$ & $\mathrm{Y}$ & $\mathrm{Y}$ & . & 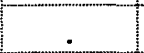 & II \\
\hline TRIFLUMIZOLE & $\mathrm{F}$ & $\mathrm{N}$ & $\mathrm{Y}$ & . & III & IV \\
\hline TRIFLUMURON & 1 & $\mathrm{~N}$ & $\mathrm{Y}$ & & $u$ & IV \\
\hline TRIFLURALINA & $\mathrm{H}$ & $Y$ & Y & U & $U$ & III \\
\hline TRIFORINE & $F$ & $\mathrm{Y}$ & $\mathrm{Y}$ & $U$ & $\mathrm{U}$ & IV \\
\hline TRITICONAZOLE & $F$ & $\mathrm{~N}$ & $Y$ & & $\mathrm{u}$ & III \\
\hline VAMIDOTHION & 1 & $\mathrm{Y}$ & Y & $\mathrm{lb}$ & $\mathrm{lb}$ & II \\
\hline VERNOLATE & $\mathrm{H}$ & Y & $Y$ & II & II & III \\
\hline VINCLOZOLIN & $\mathrm{F}$ & $Y$ & $Y$ & U & U & IV \\
\hline ZETACYPERMETHRIN & 1 & $\mathrm{~N}$ & Y & & $\mathrm{Ib}$ & II \\
\hline ZINEB & $F$ & $Y$ & $N$ & $U$ & $\mathrm{U}$ & \\
\hline ZIRAM & $\mathrm{F}$ & $Y$ & $\mathrm{Y}$ & III & III & III \\
\hline
\end{tabular}




\section{ANEXO 2 - banco de dados no 2 - Produtos Comerciais}

\section{LEGENDA}

- USO ( Classe de Uso): I - inseticida ; F - Fungicida ; H - Herbicida ;

$$
\text { O- "outros". }
$$

- 1990 (confirmação de registro em 1990): Y - Sim ; N - Não

- 2000 (confirmação de registro em 2000): Y - Sim ; N - Não

- CPA (Classe de Potencial de Periculosidade Ambiental atribuída pelo IBAMA. II - altamente perigoso ; II - muito perigoso ; III - perigoso ; IV - pouco perigoso ;

- CT90 (Classe Toxicológica constante no Compêndio de Defensivos Agrícolas, 1990):

I - altamente tóxico ; II - medianamente tóxico ; III - pouco tóxico ;

IV - praticamente não tóxico ; NA - classificação não atualizada ;

- CT98 (Classe Toxicológica constante no AGROFIT, 1998):

I - extremamente tóxico ; II - altamente tóxico ; III - medianamente tóxico ; IV - pouco tóxico ; NA - classificação não atualizada ;

\begin{tabular}{|c|c|c|c|c|c|c|}
\hline PRODUTOS COMERCIAIS & USO & 1990 & 2000 & CPA & CT90 & CT98 \\
\hline 2,4-D FERSOL & $\mathrm{H}$ & $\mathrm{Y}$ & $Y$ & NA & 1 & NA \\
\hline ACARDIFON & 1 & $Y$ & $\mathrm{~N}$ & & II & \\
\hline ACARISTOP $500 \mathrm{SC}$ & 1 & $\mathrm{Y}$ & $Y$ & $\mathrm{NA}$ & III & III \\
\hline ACEFATO FERSOL $50 \mathrm{P}$ & 1 & Y & $N$ & & III & 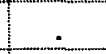 \\
\hline ACEFATO FERSOL 750 PS & 1 & $Y$ & $Y$ & III & III & IV \\
\hline ACETAMIPRID $20 \%$ PS & 1 & $N$ & Y & 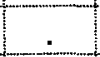 & . & 1 \\
\hline ACTARA 250 WG & 1 & $\mathrm{~N}$ & $Y$ & III & & III \\
\hline ACTELLIC $500 \mathrm{CE}$ & 1 & Y & Y & NA & II & III \\
\hline ADDIX & 0 & $Y$ & $Y$ & NA & IV & NA \\
\hline ADESIL & 0 & $\mathrm{~N}$ & $Y$ & NA & 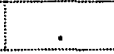 & IV \\
\hline
\end{tabular}


(continuação do Anexo II)

\begin{tabular}{|c|c|c|c|c|c|c|}
\hline PRODUTOS COMERCIAIS & USO & 1990 & 2000 & CPA & CT90 & CT98 \\
\hline ADESIN BR & 0 & $\mathrm{Y}$ & $\mathrm{N}$ & & IV & \\
\hline ADITIV & 0 & $Y$ & Y & NA & IV & NA \\
\hline ADVANCE & $\mathrm{H}$ & $\mathrm{N}$ & Y & II & & III \\
\hline AFALON 500 BR & $\mathrm{H}$ & Y & $Y$ & NA & III & NA \\
\hline AFALON SC & $\mathrm{H}$ & $Y$ & $Y$ & NA & III & III \\
\hline AFUGAN CE & $F$ & $Y$ & $Y$ & NA & II & NA \\
\hline AG-BEM & 0 & Y & Y & IV & IV & IV \\
\hline AGIMIX & $H$ & $Y$ & $Y$ & NA & II & NA \\
\hline AGR' OLEO & 0 & $\mathrm{~N}$ & Y & IV & & IV \\
\hline AGRAL & 0 & $Y$ & $Y$ & IV & IV & IV \\
\hline AGREE & 1 & $\mathrm{~N}$ & $Y$ & III & . & III \\
\hline AGREE N.A. & 1 & $\mathrm{~N}$ & $Y$ & IV & & III \\
\hline AGREX & 0 & $Y$ & $Y$ & NA & IV & NA \\
\hline AGREX'OIL VEGETAL & 1 & $\mathrm{~N}$ & $Y$ & IV & . & IV \\
\hline AGRICOL BR EC & 1 & $N$ & $Y$ & NA & - & IV \\
\hline AGRIDION 20 & 1 & $\mathrm{~N}$ & $Y$ & NA & . & IV \\
\hline AGRIMAICIN-500 & $\mathrm{F}$ & $\mathrm{N}$ & $Y$ & II &. & III \\
\hline AGRIMICINA & $F$ & $Y$ & $Y$ & NA & 1 & 1 \\
\hline AGRINOSE & $F$ & $\mathrm{~N}$ & $Y$ & NA & & IV \\
\hline AGRISATO $480 \mathrm{CS}$ & $\mathrm{H}$ & $\mathrm{N}$ & $Y$ & II & & IV \\
\hline AGRITOATO 400 & 1 & $\mathrm{~N}$ & $Y$ & NA & & 1 \\
\hline AGRITRIN SC & $\mathrm{H}$ & $Y$ & $Y$ & II & II & IV \\
\hline AGROPHOS 400 & 1 & $N$ & $Y$ & NA & & 1 \\
\hline AGROTENSIL & 0 & $Y$ & Y & NA & IV & NA \\
\hline ALACLOR NORTOX & $\mathrm{H}$ & $N$ & $Y$ & NA & & 1 \\
\hline ALIETTE & $F$ & $Y$ & $Y$ & 11 & III & IV \\
\hline ALLIANCE WG & $H$ & $N$ & $Y$ & II & & IV \\
\hline ALLISAN BR & $F$ & $Y$ & $\mathrm{~N}$ & 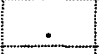 & III & \\
\hline ALLY & $\mathrm{H}$ & $N$ & $Y$ & III & . & III \\
\hline ALSYSTIN 250 PM & 1 & $N$ & Y & III & & IV \\
\hline ALTERNE & 0 & Y & $\mathrm{N}$ & . & III & \\
\hline ALTO 100 & $F$ & $N$ & $Y$ & II & & III \\
\hline ALTO GR 10 & $\mathrm{~F}$ & $\mathrm{~N}$ & $Y$ & 11 & & IV \\
\hline ALTOMIX 103,2 & $F$ & $N$ & $Y$ & 11 & . & III \\
\hline ALTOMIX 104 & $\mathrm{~F}$ & $\mathrm{~N}$ & $Y$ & II & & III \\
\hline AMBUSH $500 \mathrm{CE}$ & 1 & $Y$ & $Y$ & $\mathrm{NA}$ & $\Perp$ & NA \\
\hline AMETREX $500 \mathrm{SC}$ & $\mathrm{H}$ & $\mathrm{N}$ & $Y$ & 11 & . & IV \\
\hline AMETRON SC & $\mathrm{H}$ & $Y$ & $Y$ & NA & II & NA \\
\hline AMEX & 0 & $Y$ & $Y$ & 1 & II & II \\
\hline AMINAMAR & $H$ & $\mathrm{~N}$ & $Y$ & NA & . & 1 \\
\hline AMINOL & $\mathrm{H}$ & $Y$ & $Y$ & 1 & 1 & 1 \\
\hline AMISTAR & $F$ & $\mathrm{~N}$ & $Y$ & III & 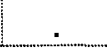 & IV \\
\hline
\end{tabular}


(continuação do Anexo II)

\begin{tabular}{|c|c|c|c|c|c|c|}
\hline PRODUTOS COMERCIAIS & USO & 1990 & 2000 & CPA & CT90 & CT98 \\
\hline AMISTAR 500 WG & $F$ & $\mathbf{N}$ & $Y$ & III & . & IV \\
\hline ANCHOR SC & $F$ & $\mathbf{N}$ & $Y$ & 1 & . & III \\
\hline ANTAK BR & 0 & $Y$ & $N$ &. & III &. \\
\hline ANTHIO & 1 & $Y$ & $\mathrm{~N}$ & . & 1 & \\
\hline ANTICAR & 1 & $Y$ & $\mathrm{~N}$ & . & II & \\
\hline ANVIL 100 SC & $F$ & $N$ & $Y$ & II & 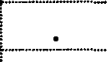 & II \\
\hline APPLAUD 250 & 1 & $N$ & Y & III & & IV \\
\hline APRON & $F$ & $Y$ & $Y$ & NA & III & NA \\
\hline AQUAMIX & 0 & $Y$ & $Y$ & NA & IV & NA \\
\hline ARRIVO $200 \mathrm{CE}$ & 1 & $Y$ & Y & 11 & 11 & NA \\
\hline ARROZAN & $\mathrm{H}$ & $Y$ & $Y$ & $\mathrm{NA}$ & II & NA \\
\hline ARSENAL 250 & $\mathrm{H}$ & $Y$ & $\mathrm{~N}$ & & II & \\
\hline ARSENAL N.A. & $H$ & $\mathrm{~N}$ & $Y$ & III & . & III \\
\hline ARVEST 480 & 0 & $\mathrm{~N}$ & $Y$ & III & . & 1 \\
\hline ASSIST & 1 & $Y$ & $Y$ & IV & IV & IV \\
\hline ASTRO & 1 & $N$ & $Y$ & 11 & & III \\
\hline ASULOX 400 & $\mathrm{H}$ & $Y$ & $Y$ & NA & III & III \\
\hline ATABRON $50 \mathrm{CE}$ & 1 & $\mathrm{~N}$ & $Y$ & II & 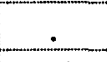 & 1 \\
\hline ATERBANE BR & 0 & $Y$ & $Y$ & NA & IV & IV \\
\hline ATRANEX $500 \mathrm{SC}$ & $\mathrm{H}$ & $N$ & $Y$ & III & & III \\
\hline ATRASIMEX $500 \mathrm{SC}$ & $\mathrm{H}$ & $\mathrm{N}$ & $Y$ & II & 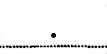 & III \\
\hline ATRAZINA NORTOX $500 \mathrm{SC}$ & $\mathrm{H}$ & $N$ & $Y$ & II & & III \\
\hline ATRAZINAX 500 & $\mathrm{H}$ & $Y$ & $Y$ & NA & III & NA \\
\hline ATTACH & 0 & $\mathrm{~N}$ & $Y$ & III & $\therefore$ & IV \\
\hline AURA & $\mathrm{H}$ & $\mathrm{N}$ & $Y$ & II & & 1 \\
\hline AURAM 700 & $\mathrm{~F}$ & $Y$ & $\mathrm{~N}$ & . & III & \\
\hline AZODRIN 400 & 1 & $Y$ & $Y$ & 1 & 1 & 1 \\
\hline AZODRIN 75 UBV & 1 & Y & $Y$ & 1 & 1 & 1 \\
\hline BAC CONTROL PM & 1 & $N$ & $Y$ & IV & . & IV \\
\hline BACTUR PM & 1 & $\mathrm{~N}$ & $Y$ & IV & 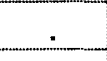 & III \\
\hline BACULOVIRUS NITRAL & 1 & $N$ & Y & IV & & IV \\
\hline BANIR & $\mathrm{H}$ & $Y$ & $Y$ & NA & II & II \\
\hline BANVEL 480 & $\mathrm{H}$ & $Y$ & $Y$ & III & III & III \\
\hline BASAGRAN 480 & $\mathrm{H}$ & $\mathrm{Y}$ & $Y$ & III & II & II \\
\hline BASAMID & $F$ & $N$ & $Y$ & III & . & III \\
\hline BASUDIN 140 GR & 1 & $Y$ & $N$ & - & III & . \\
\hline BASUDIN $25 \mathrm{P}$ & 1 & $Y$ & $N$ & & III & \\
\hline BAYCOR & $F$ & $Y$ & $Y$ & NA & III & NA \\
\hline BAYFIDAN 60 GR & $F$ & $\mathrm{~N}$ & $Y$ & III & 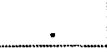 & IV \\
\hline BAYFIDAN CE & $\mathrm{F}$ & $Y$ & $Y$ & II & II & II \\
\hline BAYFIDAN PM & $F$ & $\mathrm{~N}$ & $Y$ & III & . & III \\
\hline
\end{tabular}


(continuação do Anexo II)

\begin{tabular}{|c|c|c|c|c|c|c|}
\hline PRODUTOS COMERCIAIS & USO & 1990 & 2000 & CPA & CT90 & СT98 \\
\hline BAYLETON BR & $\mathrm{F}$ & $\mathrm{Y}$ & $\mathrm{Y}$ & NA & III & NA \\
\hline BAYSISTON GR & 1 & Y & $\mathrm{Y}$ & II & 1 & NA \\
\hline BAYTAN 150 & $\mathrm{~F}$ & $\mathrm{Y}$ & $\mathrm{N}$ & & III & \\
\hline BAYTAN 250 & $F$ & $Y$ & $Y$ & NA & III & NA \\
\hline BAYTAN SC & $F$ & $Y$ & $\mathrm{Y}$ & 11 & III & NA \\
\hline BAYTROID CE & 1 & $Y$ & $\bar{Y}$ & II & 1 & NA \\
\hline BELMARK 25 UBV & 1 & $Y$ & $\mathrm{Y}$ & NA & II & NA \\
\hline BELMARK 75 CE & 1 & $Y$ & $Y$ & NA & 1 & 1 \\
\hline BENDAZOL & $\mathrm{F}$ & $Y$ & $Y$ & NA & III & NA \\
\hline BENLATE 500 & $F$ & $Y$ & $Y$ & NA & III & NA \\
\hline BENLATE TS & $F$ & $\mathrm{~N}$ & $Y$ & & & III \\
\hline BI-HEDONAL & $\mathrm{H}$ & $\mathrm{Y}$ & $\mathrm{N}$ & & II & \\
\hline BIM 500 SC & $F$ & $Y$ & $Y$ & NA & III & NA \\
\hline BIM 750 BR & $F$ & $\mathrm{Y}$ & $Y$ & $\mathrm{NA}$ & II & NA \\
\hline BIMATE PM & $\mathrm{H}$ & $Y$ & $Y$ & NA & II & III \\
\hline BIRLANE $250 \mathrm{P}$ & 1 & $\mathrm{Y}$ & $Y$ & NA & 1 & NA \\
\hline BIRLANE 50 PO & 1 & $\mathrm{~N}$ & $Y$ & & & 1 \\
\hline BISTAR & 1 & $\mathrm{~N}$ & Y & II & . & IV \\
\hline BISTAR UBV & 1 & $\mathrm{~N}$ & $\mathrm{Y}$ & II & & IV \\
\hline BLADAL 700 & $\mathrm{H}$ & $Y$ & $\mathrm{~N}$ & & III & \\
\hline BLADAL SC & $\mathrm{H}$ & $\mathrm{Y}$ & $Y$ & NA & II & III \\
\hline BLADEX 500 & $\mathrm{H}$ & $Y$ & $\bar{Y}$ & 1 & III & III \\
\hline BLASON $480 \mathrm{SC}$ & $F$ & $\mathrm{~N}$ & $Y$ & 11 & & II \\
\hline BLAZER SOL & $\mathrm{H}$ & $\mathrm{Y}$ & $Y$ & II & 1 & 1 \\
\hline BLAZINA SC & $H$ & $Y$ & $Y$ & NA & II & NA \\
\hline BLITZ & 1 & $\mathrm{~N}$ & $Y$ & III & & IV \\
\hline BLITZF & 1 & $\mathrm{~N}$ & $Y$ & III & & IV \\
\hline B-NINE 850 P.S. & 0 & $\mathrm{~N}$ & $Y$ & III & & IV \\
\hline BORAL $500 \mathrm{SC}$ & $\mathrm{H}$ & $\mathrm{N}$ & $Y$ & III & & IV \\
\hline BORDAMIL & $F$ & $\bar{Y}$ & $Y$ & NA & IV & NA \\
\hline BOTRAN 750 & $\mathrm{~F}$ & $\mathrm{~N}$ & $Y$ & II & & III \\
\hline BOXER & $\mathrm{H}$ & $\mathrm{Y}$ & $Y$ & NA & 1 & 11 \\
\hline BRAVIK $600 \mathrm{CE}$ & 1 & $\mathrm{~N}$ & $Y$ & NA & & 1 \\
\hline BRAVOCARB 500 SC & $F$ & $N$ & $Y$ & II & $\therefore$ & III \\
\hline BRAVONIL 500 & $F$ & $\mathrm{~N}$ & $Y$ & III & & 1 \\
\hline BRAVONIL 500 SDS & $\mathrm{F}$ & $Y$ & $Y$ & II & 1 & 1 \\
\hline BRAVONIL 750 PM & $\mathrm{F}$ & $Y$ & $Y$ & II & II & 11 \\
\hline BRAVONIL ULTREX & $\mathrm{F}$ & $N$ & $Y$ & II & & 1 \\
\hline BREAK THRU (SILICONE) & 0 & $\mathrm{~N}$ & $Y$ & III & & III \\
\hline & $\mathrm{F}$ & $Y$ & $N$ & & & \\
\hline
\end{tabular}


(continuação do Anexo II)

\begin{tabular}{|c|c|c|c|c|c|c|}
\hline PRODUTOS COMERCIAIS & USO & 1990 & 2000 & CPA & СТ90 & CT98 \\
\hline BRESTAN PM & $\mathrm{F}$ & $\mathrm{Y}$ & $Y$ & NA & II & NA \\
\hline BRESTANID SC & $F$ & $\mathrm{~N}$ & $Y$ & 1 & & 1 \\
\hline BRIGADE 25 CE & 1 & $\mathrm{~N}$ & $Y$ & II & 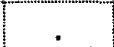 & II \\
\hline BROMETILA & 1 & $\mathrm{~N}$ & $Y$ & NA & 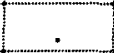 & 1 \\
\hline BROMEX & 1 & $Y$ & $\bar{Y}$ & NA & 1 & NA \\
\hline BROMO FLORA & 1 & $Y$ & Y & NA & 1 & NA \\
\hline BROMO-FERSOL & 1 & $Y$ & $Y$ & NA & 1 & NA \\
\hline BULLDOCK 125 SC & 1 & $\mathrm{~N}$ & $Y$ & 1 & . & 11 \\
\hline BUNEMA $330 \mathrm{CS}$ & 1 & $N$ & $Y$ & 1 & . & II \\
\hline CALIGUR & 1 & $N$ & $Y$ & 1 & . & 1 \\
\hline CAPRI & $\mathrm{H}$ & $N$ & $Y$ & II &. & 1 \\
\hline CAPTAN 200 FUNG. AGROCERES & $\mathrm{F}$ & $\mathrm{N}$ & Y & NA & & 1 \\
\hline CAPTAN 250 MOLY & $F$ & $Y$ & $Y$ & NA & III & NA \\
\hline CAPTAN 480 SC DEFENSA & $F$ & $Y$ & $Y$ & NA & III & NA \\
\hline CAPTAN 500 PM & $\mathrm{F}$ & Y & Y & NA & III & NA \\
\hline CAPTAN 750 TS & $F$ & Y & Y & NA & III & NA \\
\hline CAPTAN FERSOL 500 PM & $\mathrm{F}$ & Y & $Y$ & NA & III & NA \\
\hline CAPTAN SC & $\mathrm{F}$ & Y & Y & NA & III & NA \\
\hline CARBALATE $480 \mathrm{SC}$ & 1 & Y & N &. & II & \\
\hline CARBARIL 480 SC DEFENSA & 1 & $\mathrm{Y}$ & $\mathrm{N}$ & . & II & \\
\hline CARBARYL FERSOL $480 \mathrm{SC}$ & 1 & $Y$ & $Y$ & NA & II & NA \\
\hline CARBARYL FERSOL $50 \mathrm{P}$ & 1 & $\mathrm{Y}$ & $\mathrm{N}$ & & III & \\
\hline CARBARYL FERSOL 850 PM & 1 & $Y$ & $Y$ & NA & II & NA \\
\hline CARBARYL FERSOL PO 75 & 1 & $Y$ & $Y$ & NA & III & NA \\
\hline CARBAX & 1 & Y & Y & NA & II & II \\
\hline CARBION $75 \mathrm{P}$ & 1 & Y & $\mathrm{N}$ & . & III & \\
\hline CARBOFURAN SANACHEM 350 TS & 1 & $\mathrm{~N}$ & Y & 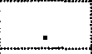 & . & 1 \\
\hline CARBORAN FERSOL $350 \mathrm{SC}$ & 1 & $Y$ & $Y$ & NA & 1 & NA \\
\hline CARBORAN FERSOL $50 \mathrm{G}$ & 1 & Y & Y & NA & 1 & NA \\
\hline CARTAP BR 500 & 1 & $Y$ & $Y$ & II & II & III \\
\hline CARVIN 850 PM & 1 & Y & $N$ & . & II & \\
\hline CASCADE 100 & 1 & $\mathrm{~N}$ & $Y$ & II & . & 1 \\
\hline CASORON 67,5 GR & $\mathrm{H}$ & $Y$ & $\mathrm{~N}$ & 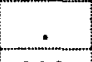 & III & \\
\hline CEFANOL & 1 & $Y$ & $Y$ & NA & III & NA \\
\hline CENTION 800 & $\mathrm{H}$ & $Y$ & $\mathrm{~N}$ & & III & \\
\hline CENTION SC & $\mathrm{H}$ & $Y$ & $Y$ & NA & III & III \\
\hline CERCOBIN 500 SC & $\mathrm{F}$ & $\mathrm{Y}$ & $Y$ & III & IV & NA \\
\hline CERCOBIN 700 PM & $F$ & $Y$ & $Y$ & II & IV & NA \\
\hline CERCONIL PM & $F$ & $Y$ & $Y$ & NA & 11 & NA \\
\hline CERCONIL SC & $F$ & $Y$ & $Y$ & II & III & NA \\
\hline CHART & $\mathrm{H}$ & $\mathrm{N}$ & $Y$ & III &. & II \\
\hline CHOPPER N.A. & $\mathrm{H}$ & $\mathrm{N}$ & Y & . & & III \\
\hline
\end{tabular}


(continuação do Anexo II)

\begin{tabular}{|c|c|c|c|c|c|c|}
\hline PRODUTOS COMERCIAIS & USO & 1990 & 2000 & CPA & CT90 & CT98 \\
\hline $\mathrm{CICOL}$ & 1 & $Y$ & $\mathrm{~N}$ & III & II & \\
\hline CIPERTRIN & 1 & $\mathrm{~N}$ & $Y$ & 1 & & 1 \\
\hline CITOWETT 200 & 0 & $\mathrm{Y}$ & $N$ & & IV & \\
\hline CITREX & 1 & $N$ & $Y$ & II & . & III \\
\hline CITROTEX & I & $\mathrm{N}$ & $Y$ & IV & . & IV \\
\hline CLASSIC & $\mathrm{H}$ & $Y$ & Y & III & III & NA \\
\hline CLEAN RICE & $\mathrm{H}$ & $N$ & Y & NA & 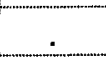 & II \\
\hline CLOROBENZILATO 500 CE FERSOL & 1 & Y & $N$ & & II & \\
\hline CLORPIRIFOS 480 CE DEFENSA & 1 & Y & $\mathrm{Y}$ & NA & II & NA \\
\hline CLORPIRIFOS FERSOL $480 \mathrm{CE}$ & 1 & N & $Y$ & 1 & . & II \\
\hline COACT $360 \mathrm{CE}$ & $\mathrm{H}$ & Y & $N$ & & 11 & \\
\hline COBOX & $F$ & $\mathrm{~N}$ & $Y$ & III & . & IV \\
\hline COBRA & $H$ & $Y$ & $Y$ & II & 1 & 1 \\
\hline COBRE FERSOL & $\mathrm{F}$ & Y & $\mathrm{N}$ & & IV & \\
\hline COBRE SANDOZ BR & $\mathrm{F}$ & $Y$ & $Y$ & NA & IV & NA \\
\hline COBRE SANDOZ P & $F$ & $Y$ & $\mathrm{~N}$ & 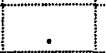 & IV & \\
\hline COBRE SANDOZ SC & $F$ & $Y$ & $\mathrm{Y}$ & NA & IV & NA \\
\hline COMBILAN PM & $F$ & $Y$ & $Y$ & NA & III & NA \\
\hline COMBINE 500 SC & $\mathrm{H}$ & $Y$ & $Y$ & NA & IV & IV \\
\hline COMMANCHE $200 \mathrm{CE}$ & 1 & $N$ & Y & II & & III \\
\hline COMMAND & $\mathrm{H}$ & $Y$ & $Y$ & NA & I & NA \\
\hline COMMENCE $630 \mathrm{CE}$ & $\mathrm{H}$ & $Y$ & $N$ & . & 11 & \\
\hline CONDOR $200 \mathrm{CE}$ & $F$ & $\mathrm{~N}$ & $Y$ & II & & II \\
\hline CONDOR 200 SC & $F$ & $N$ & $\mathrm{Y}$ & II & & III \\
\hline CONFIDOR 700 GRDA & 1 & $N$ & $Y$ & III & . & IV \\
\hline CONFIDOR S & 1 & $N$ & $Y$ & II & & IV \\
\hline CONTACT & $\mathrm{F}$ & $N$ & $Y$ & III & . & IV \\
\hline CONTAIN & $\mathrm{H}$ & $N$ & Y & III & . & III \\
\hline CONTROLER $500 \mathrm{SC}$ & $H$ & $N$ & $Y$ & 11 & & IV \\
\hline COOPERVIRUS PM & 1 & $\mathrm{~N}$ & $Y$ & IV & . & IV \\
\hline COPIDROL PM & $F$ & $Y$ & $Y$ & NA & IV & NA \\
\hline COPIDROL SC & $\mathrm{F}$ & $Y$ & $Y$ & NA & IV & NA \\
\hline COPRANTOL BR & $F$ & $Y$ & $N$ & - & IV & 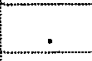 \\
\hline CORBEL & $F$ & $N$ & $Y$ & II & & II \\
\hline CORDIAL 100 & 1 & $N$ & $Y$ & II & & 1 \\
\hline CORSAIR $500 \mathrm{CE}$ & 1 & $N$ & $Y$ & NA & & II \\
\hline CORSUM & $\mathrm{H}$ & $Y$ & $Y$ & NA & III & NA \\
\hline COUNTER $150 \mathrm{G}$ & 1 & $\mathrm{~N}$ & $Y$ & II & & 1 \\
\hline COUNTER $50 \mathrm{G}$ & 1 & $N$ & $Y$ & 1 & & 1 \\
\hline CROP OIL & 1 & $N$ & Y & IV & & IV \\
\hline CRUISER 700 WS & 1 & $N$ & $Y$ & III & & III \\
\hline
\end{tabular}




\begin{tabular}{|c|c|c|c|c|c|c|}
\hline PRODUTOS COMERCIAIS & USO & 1990 & 2000 & CPA & CT90 & CT98 \\
\hline CUPRAVIT AZUL 500 & $F$ & $Y$ & $N$ & & IV & \\
\hline CUPRAVIT AZUL BR & $F$ & $Y$ & $Y$ & IV & IV & IV \\
\hline CUPRAVIT VERDE & $F$ & $Y$ & $Y$ & 11 & IV & NA \\
\hline CUPRODIL & $F$ & Y & $\bar{Y}$ & NA & II & III \\
\hline CUPROGARB 350 & $F$ & $N$ & $Y$ & II & . & IV \\
\hline CUPROGARB 500 & $\mathrm{~F}$ & $N$ & Y & III &. & IV \\
\hline CUPROSAN AZUL PM & $F$ & $Y$ & $N$ & & IV & \\
\hline CUPROZEB & $F$ & Y & Y & NA & III & NA \\
\hline CURACRON 500 & 1 & $Y$ & $Y$ & II & 11 & III \\
\hline CURAVIAL & 0 & $\mathrm{~N}$ & Y & II & . & III \\
\hline CURINGA & 1 & $N$ & $Y$ & II & & III \\
\hline CURZATE M + ZINCO & $F$ & $\mathrm{Y}$ & Y & NA & III & NA \\
\hline CYCOCEL $100 \mathrm{~A}$ & 0 & $Y$ & $N$ &. & III & . \\
\hline CYCOCEL $500 \mathrm{~A}$ & 0 & $Y$ & $\mathrm{~N}$ & . & III & \\
\hline CYMBUSH $250 \mathrm{CE}$ & 1 & Y & Y & 1 & II & II \\
\hline CYMBUSH 30 ED BICO BRANCO & 1 & $\mathrm{Y}$ & $Y$ & NA & III & NA \\
\hline CYMBUSH 40 ED BICO AMARELO & 1 & $\mathrm{Y}$ & $Y$ & NA & III & NA \\
\hline CYPTRIN $250 \mathrm{CE}$ & 1 & $\mathrm{~N}$ & $\mathrm{Y}$ & 1 & . & 1 \\
\hline CYTHION 1000 & 1 & Y & $\mathrm{N}$ & . & II & . \\
\hline CYTHION UBV & 1 & $Y$ & $Y$ & NA & III & IV \\
\hline DACOBRE PM & $F$ & $Y$ & $Y$ & NA & 11 & NA \\
\hline DACONATE 480 & $\mathrm{H}$ & $\mathbf{N}$ & $Y$ & II & . & II \\
\hline DACONIL 500 & $\mathrm{~F}$ & $N$ & $Y$ & II & . & 1 \\
\hline DACONIL BR & $F$ & $Y$ & $Y$ & NA & II & NA \\
\hline DACOSTAR 500 & $F$ & $\bar{Y}$ & $Y$ & $\mathrm{NA}$ & 1 & NA \\
\hline DACOSTAR 750 & $F$ & $Y$ & $Y$ & NA & II & II \\
\hline DACTHAL 750 PM & $\mathrm{H}$ & $\mathrm{N}$ & Y & II & & III \\
\hline DANIMEN $300 \mathrm{CE}$ & 1 & $Y$ & $Y$ & II & 1 & 1 \\
\hline DASH HC & 0 & $N$ & $Y$ & IV & . & II \\
\hline DDVP 1000 CE DEFENSA & 1 & Y & $Y$ & NA & 1 & NA \\
\hline DDVP 500 CE CALAIS & 1 & $Y$ & $N$ & & 1 & . \\
\hline DDVP 500 CE DEFENSA & 1 & $Y$ & $Y$ & NA & 1 & 1 \\
\hline DECIS $200 \mathrm{SC}$ & 1 & $N$ & $\mathrm{Y}$ & III & . & IV \\
\hline DECIS 25 CE & 1 & $Y$ & $Y$ & 1 & II & II \\
\hline DECIS 4 UBV & 1 & $Y$ & $Y$ & 1 & III & III \\
\hline DECIS 50 SC & 1 & $Y$ & $Y$ & 1 & III & IV \\
\hline DECIS FOG FORMICIDA & 1 & $Y$ & $Y$ & NA & III & NA \\
\hline DECIS FORMICIDA $4 \mathrm{P}$ & 1 & $Y$ & $Y$ & NA & IV & NA \\
\hline DECIS ULTRA $100 \mathrm{CE}$ & 1 & $\mathbf{N}$ & $Y$ & & . & 1 \\
\hline DECISDAN CE & 1 & $Y$ & $Y$ & NA & 1 & 1 \\
\hline DECIS-TAB & 1 & $N$ & Y & III &. & III \\
\hline
\end{tabular}




\begin{tabular}{|c|c|c|c|c|c|c|}
\hline \multirow[b]{2}{*}{ PRODUTOS COMERCIAIS } & \multicolumn{6}{|c|}{ (continuação do Anexo II) } \\
\hline & USO & 1990 & 2000 & CPA & CT90 & СТ98 \\
\hline DEFERON & $\mathrm{H}$ & $\bar{Y}$ & $\mathrm{Y}$ & NA & II & NA \\
\hline DELAN & $\mathrm{F}$ & $\mathrm{Y}$ & $\mathrm{Y}$ & NA & II & NA \\
\hline DELTAPHOS & 1 & $N$ & Y & & . & 1 \\
\hline DEROSAL 500 SC & $F$ & $N$ & Y & III & . & III \\
\hline DESSECAN & $\mathrm{H}$ & Y & $Y$ & NA & II & NA \\
\hline DEVRINOL 500 PM & $\mathrm{H}$ & $Y$ & $\mathrm{Y}$ & NA & III & NA \\
\hline DIAFURAN 50 & 1 & $Y$ & $Y$ & NA & 1 & NA \\
\hline DIAZINON 400 PM CIBA-GEIGY & 1 & $Y$ & $Y$ & II & III & 1 \\
\hline DIAZINON $600 \mathrm{CE}$ & 1 & $Y$ & $Y$ & NA & II & III \\
\hline DICAROL CE & 1 & $\mathrm{Y}$ & $\mathrm{N}$ & & IV & \\
\hline DICARZOL 500 PS & 1 & $\mathrm{~N}$ & $Y$ & 11 & & 1 \\
\hline DICOFOL AGRIPEC CE & 1 & $\mathrm{~N}$ & $\mathrm{Y}$ & II & " & II \\
\hline DICOFOL FERSOL $185 \mathrm{CE}$ & 1 & $Y$ & $Y$ & II & II & 11 \\
\hline DICOFOL FERSOL $480 \mathrm{CE}$ & 1 & $N$ & $Y$ & 11 & & II \\
\hline DICOFOL HERBITECNICA CE & 1 & $Y$ & $\mathbf{N}$ & & II & \\
\hline DICOFOL MILENIA CE & 1 & $N$ & $Y$ & 11 & & II \\
\hline DICOFOL NORTOX & 1 & $N$ & $Y$ & II & 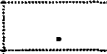 & II \\
\hline DIK $185 \mathrm{CE}$ & 1 & $Y$ & $Y$ & II & II & 1 \\
\hline DIMECRON 500 & 1 & $Y$ & $Y$ & NA & 1 & 1 \\
\hline DIMETHOATO FERSOL $400 \mathrm{CE}$ & 1 & $Y$ & $Y$ & NA & 1 & 1 \\
\hline DIMETOATO 200 GR NORTOX & 1 & $Y$ & Y & NA & II & 11 \\
\hline DIMETOATO 500 CE NORTOX & 1 & $Y$ & N & II & 1 & \\
\hline DIMETOATO CE & 1 & $Y$ & $\mathrm{Y}$ & NA & 1 & II \\
\hline DIMEXION & 1 & Y & $Y$ & 11 & 1 & II \\
\hline DIMILIN & 1 & $Y$ & $Y$ & III & IV & IV \\
\hline DIPEL & 1 & $\mathrm{~N}$ & $Y$ & IV & & IV \\
\hline DIPELF & 1 & $\mathrm{~N}$ & $Y$ & IV & & IV \\
\hline DIPELPM & 1 & $Y$ & $Y$ & NA & IV & NA \\
\hline DIPTEREX 500 & 1 & $Y$ & $Y$ & NA & II & 11 \\
\hline DIPTEREX PO 25 & 1 & $Y$ & $N$ & & III & \\
\hline DIRECT G.A.A. & $\mathrm{H}$ & $Y$ & $Y$ & II & IV & IV \\
\hline DISSECA 200 & $\mathrm{H}$ & $Y$ & $N$ & & 1 & \\
\hline DISSULFAN CE & 1 & $Y$ & $Y$ & 1 & 1 & NA \\
\hline DISSULFAN UBV & 1 & $Y$ & $Y$ & NA & 1 & 1 \\
\hline DISYSTON GR 100 & 1 & $Y$ & $Y$ & NA & 1 & NA \\
\hline DISYSTON GR 50 & 1 & $Y$ & $N$ & & 1 & \\
\hline DITHANE PM & $F$ & $Y$ & $N$ & II & III & \\
\hline DITHANE SC & $\mathrm{F}$ & $Y$ & $N$ & & III & \\
\hline DITHIOBIN 780 PM & $F$ & $Y$ & $Y$ & NA & II & NA \\
\hline DIUREX AGRICUR 500 SC & $\mathrm{H}$ & $\mathbf{N}$ & Y & NA & & II \\
\hline DIURON 480 + AMETRINA 310 NORTOX & $\mathrm{H}$ & $Y$ & $N$ & & III & \\
\hline
\end{tabular}




\begin{tabular}{|c|c|c|c|c|c|c|}
\hline PRODUTOS COMERCIAIS & USO & 1990 & 2000 & CPA & CT90 & CT98 \\
\hline DIURON 500 SC & $\mathrm{H}$ & $\mathrm{N}$ & Y & NA & . & II \\
\hline DIURON 500 SC DEFENSA & $\mathrm{H}$ & $\mathrm{Y}$ & $\mathrm{Y}$ & NA & II & II \\
\hline DIURON FERSOL 500 SC & $\mathrm{H}$ & $Y$ & $Y$ & NA & II & NA \\
\hline DIURON FERSOL 800 PM & $\mathrm{H}$ & $Y$ & $Y$ & NA & III & NA \\
\hline DIURON NORTOX & $\mathrm{H}$ & $Y$ & $Y$ & II & III & III \\
\hline DIURON NORTOX 500 SC & $\mathrm{H}$ & $\mathrm{N}$ & Y & II & & IV \\
\hline DIURON PM HOECHST & $\mathrm{H}$ & $\mathrm{Y}$ & $\mathrm{N}$ & & III & \\
\hline DIURON SC HOECHST & $\mathrm{H}$ & $\mathrm{Y}$ & $Y$ & $\mathrm{NA}$ & II & II \\
\hline DMA 480 BR & $\mathrm{H}$ & $Y$ & $\mathrm{~N}$ & & 1 & \\
\hline DMA 806 BR & $\mathrm{H}$ & $Y$ & $Y$ & NA & 1 & NA \\
\hline DOBLE & $\mathrm{H}$ & $\mathrm{N}$ & $\mathrm{Y}$ & II &. & II \\
\hline DODEX $450 \mathrm{SC}$ & $\mathrm{F}$ & $\mathrm{Y}$ & $\mathrm{Y}$ & NA & 1 & NA \\
\hline DOMARK $100 \mathrm{CE}$ & $F$ & $N$ & Y & II & & II \\
\hline DONTOR & $\mathrm{H}$ & Y & Y & NA & 1 & NA \\
\hline DORMEX & 0 & $N$ & $Y$ & II & . & 1 \\
\hline DOSER & 1 & $\mathrm{~N}$ & Y & 1 & . & II \\
\hline DROPP 500 PM & $\mathrm{H}$ & $N$ & $Y$ & NA & & III \\
\hline DROPP ULTRA SC & $\mathrm{H}$ & $N$ & Y & II & 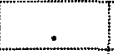 & IV \\
\hline DU FOL & 0 & $Y$ & $N$ &. & IV & \\
\hline DUAL $720 \mathrm{CE}$ & $\mathrm{H}$ & Y & $\mathrm{N}$ & . & II & \\
\hline DUAL $960 \mathrm{CE}$ & $\mathrm{H}$ & $Y$ & $Y$ & 1 & II & II \\
\hline DUPLEX & $\mathrm{H}$ & $N$ & $Y$ & 11 & 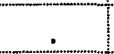 & III \\
\hline DYRENE 480 & $F$ & $Y$ & $Y$ & II & II & III \\
\hline DYTROL & 1 & $N$ & $Y$ & III & $\therefore$ & IV \\
\hline ECOTECH PRO & 1 & $\mathrm{~N}$ & $Y$ & IV &. & III \\
\hline EFFECT & $F$ & $\mathbf{N}$ & $Y$ & II & . & II \\
\hline EKATIN & 1 & $Y$ & $Y$ & NA & II & III \\
\hline ELOSAL SC & $\mathrm{F}$ & $\mathrm{Y}$ & $N$ & . & IV & \\
\hline ELSAN & 1 & $\mathrm{~N}$ & $\mathrm{Y}$ & NA & & 1 \\
\hline ENDOSULFAN 350 CE DEFENSA & 1 & $Y$ & $\mathrm{Y}$ & NA & 1 & NA \\
\hline ENDOSULFAN AG & 1 & $\mathrm{~N}$ & 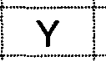 & NA & . & II \\
\hline ENDOSULFAN FERSOL $350 \mathrm{CE}$ & 1 & $Y$ & $Y$ & 1 & 1 & NA \\
\hline ENDOZOL & 1 & $Y$ & $\mathrm{Y}$ & NA & II & II \\
\hline ENERGIC & 0 & $Y$ & $Y$ & IV & IV & IV \\
\hline ENXOFRE FERSOL 520 SC & 1 & $\mathrm{~N}$ & $\mathrm{Y}$ & IV & & IV \\
\hline ENXOFRE PM AGRIPEC & $\mathrm{F}$ & $\mathrm{N}$ & Y & NA & 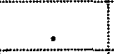 & IV \\
\hline EPTAM 720 CE & $\mathrm{H}$ & $Y$ & Y & NA & II & II \\
\hline EQUATION & $F$ & $N$ & Y &. &. & III \\
\hline ERADICANE & $\mathrm{H}$ & $Y$ & Y & NA & ॥I & II \\
\hline ERBAN 360 & $\mathrm{H}$ & $Y$ & $N$ & . & 11 & \\
\hline ERBAN 480 & $\mathrm{H}$ & $Y$ & $N$ &. & II & \\
\hline
\end{tabular}


(continuação do Anexo II)

\begin{tabular}{|c|c|c|c|c|c|c|}
\hline PRODUTOS COMERCIAIS & USO & 1990 & 2000 & CPA & CT90 & СТ98 \\
\hline ESPALHANTE ADESIVO BAYER & 0 & Y & $\mathrm{Y}$ & IV & IV & III \\
\hline ESPALHANTE ADESIVO DU FOL & 0 & $N$ & Y & IV & & III \\
\hline ESPALHANTE ADESIVO FERSOL & 0 & $Y$ & $Y$ & NA & IV & NA \\
\hline ESPALHANTE ADESIVO FERTIBRAS & 0 & Y & $\mathrm{Y}$ & NA & IV & IV \\
\hline ESTERON $400 \mathrm{BR}$ & $\mathrm{H}$ & $N$ & $\mathrm{Y}$ & NA & & II \\
\hline ETHEPHON 480 CS SANACHEN & 0 & $N$ & Y & III & & I \\
\hline ETHION 500 RHODIA AGRO & 1 & $Y$ & Y & NA & I & NA \\
\hline ETHION 500 RPA & 1 & $N$ & $\bar{Y}$ & & & 1 \\
\hline ETHREL & 0 & Y & Y & III & III & III \\
\hline ETHREL 2,5 PT & 0 & $Y$ & $\mathrm{~N}$ & III & III & \\
\hline ETHREL 720 & 0 & $\mathrm{~N}$ & $\mathrm{Y}$ & III & & II \\
\hline ETHREL PT & 0 & $Y$ & $\mathrm{~N}$ & III & III & \\
\hline EUPAREN M 500 PM & $\mathrm{F}$ & $\mathrm{N}$ & Y & II & & III \\
\hline EXTRAVON & 0 & $Y$ & $\mathrm{Y}$ & NA & IV & NA \\
\hline EXTRAZIN SC & $\mathrm{H}$ & $\mathrm{N}$ & $Y$ & NA & & III \\
\hline FACET DF & $\mathrm{H}$ & $N$ & $Y$ & II & & III \\
\hline FACET PM & $\mathrm{H}$ & $\bar{Y}$ & Y & NA & III & NA \\
\hline FACTOR & $\mathrm{H}$ & $Y$ & $N$ & & . & \\
\hline FALCON 250WG & $\mathrm{H}$ & $\mathrm{N}$ & $Y$ & II & . & III \\
\hline FARO & 1 & $N$ & $\mathrm{Y}$ & II & . & $\|$ \\
\hline FASTAC 100 & 1 & $\mathrm{~N}$ & $Y$ & 1 & . & 1 \\
\hline FASTAC $100 \mathrm{SC}$ & 1 & $\mathrm{~N}$ & $Y$ & II & 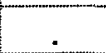 & III \\
\hline FAZOR CS & 0 & $\mathrm{~N}$ & $Y$ & III & . & II \\
\hline FENIX & 1 & $Y$ & $\mathrm{~N}$ & . & 1 & \\
\hline FENVALERATE 200 CE DEFENSA & 1 & Y & Y & NA & 1 & II \\
\hline FERMAG & 1 & $Y$ & Y & 1 & 1 & NA \\
\hline FERRAX 400 ED BICO AMARELO & 1 & $Y$ & $Y$ & NA & III & III \\
\hline FERTOXIN BR & 1 & Y & $\mathrm{N}$ & & 1 & \\
\hline FINALE & $\mathrm{H}$ & $N$ & Y & III & . & III \\
\hline FINISH & 0 & $N$ & $\mathrm{Y}$ & II & 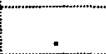 & 1 \\
\hline FIST CE & $\mathrm{H}$ & $\mathbf{N}$ & Y & II & 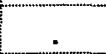 & 11 \\
\hline FIXADE & 0 & $Y$ & Y & NA & IV & NA \\
\hline FLEX & $\mathrm{H}$ & $\bar{Y}$ & $Y$ & II & 1 & 1 \\
\hline FLOUCOBRE FERSOL & $F$ & $Y$ & $Y$ & NA & IV & NA \\
\hline FLOUGURAN & $F$ & $Y$ & $\mathrm{~N}$ & & IV & \\
\hline FLUMYZIN 500 & $\mathrm{H}$ & $N$ & $Y$ & III & & III \\
\hline FLURAMIM & 1 & $\mathrm{~N}$ & $Y$ & II & & IV \\
\hline FLURAMIM N.A. & 1 & $\mathrm{~N}$ & $Y$ & II & & IV \\
\hline FOLICUR $200 \mathrm{CE}$ & $F$ & $N$ & $Y$ & II & & III \\
\hline FOLICUR CE & $F$ & Y & $Y$ & II & III & NA \\
\hline FOLICUR PM & $\mathrm{F}$ & $N$ & Y & III & . & III \\
\hline
\end{tabular}


(continuação do Anexo II)

\begin{tabular}{|c|c|c|c|c|c|c|}
\hline PRODUTOS COMERCIAIS & USO & 1990 & 2000 & CPA & CT90 & CT98 \\
\hline FOLIDOL 600 & I & $\mathrm{Y}$ & $\mathrm{N}$ & . & I & \\
\hline FOLIMAT 1000 & 1 & Y & $\mathrm{N}$ & 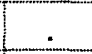 & 1 & \\
\hline FOLIO & $F$ & $N$ & Y & II & . & 11 \\
\hline FOLISUPER $600 \mathrm{BR}$ & 1 & $\mathrm{~N}$ & Y & NA & & 1 \\
\hline FOLPAN AGRICUR 500 PM & $F$ & $N$ & Y & NA & & IV \\
\hline FOLPET 500 PM & $F$ & $Y$ & Y & NA & IV & NA \\
\hline FONGORENE & $F$ & $Y$ & Y & NA & III & NA \\
\hline FORMICIDA DEFENSA GR 45 & 1 & $\mathrm{Y}$ & $\mathrm{N}$ & & II & \\
\hline FORMICIDA GRANULAD DINAGRO-S & 1 & $\mathrm{~N}$ & Y & III & . & IV \\
\hline FORMICIDA GRANULAD PIKAPAU-S & 1 & $N$ & $Y$ & III & & IV \\
\hline FORMICIDA GRANULADO LANDRIN & 1 & $\mathrm{Y}$ & $\mathrm{N}$ & $\cdot$ & III & \\
\hline FORMILIN & 1 & $Y$ & $\mathrm{~N}$ & . & IV & \\
\hline FORMIREX & 1 & $Y$ & N & . & II & \\
\hline FORMULA 480 BR & $\mathrm{H}$ & $\mathrm{Y}$ & $\mathrm{N}$ & . & 1 & \\
\hline FORTEX SC & $\mathrm{H}$ & $\mathrm{Y}$ & $\mathrm{N}$ & 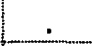 & II & \\
\hline FORUM & $F$ & $\mathbf{N}$ & $Y$ & III & & III \\
\hline FOSFERNO 500 ED BICO AMARELO & 1 & $\mathrm{Y}$ & $Y$ & NA & III & III \\
\hline FRIGATE & 0 & $\mathrm{Y}$ & $\mathrm{N}$ &. & IV & \\
\hline FRONT PM & $\mathrm{H}$ & Y & $\mathrm{N}$ & . & IV & \\
\hline FROWNCIDE 500 SC & $\mathrm{F}$ & $\mathrm{N}$ & $\mathrm{Y}$ & 1 & & II \\
\hline FRUITONE & 0 & $Y$ & $N$ & & III & \\
\hline FRUMIN & 1 & $Y$ & $\mathrm{Y}$ & NA & 1 & 1 \\
\hline FUNGINEB 800 & $\mathrm{~F}$ & Y & $\mathrm{N}$ & $-F$ & III & . \\
\hline FUNGINIL & $F$ & Y & $\mathrm{N}$ & 1 & 1 & \\
\hline FUNGISCAN 500 SC & $F$ & $Y$ & $N$ & 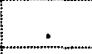 & IV & \\
\hline FUNGISCAN 700 PM & $F$ & Y & $Y$ & III & IV & NA \\
\hline FUNGITOL AZUL & $F$ & $\mathrm{~N}$ & $Y$ & & & IV \\
\hline FUNGITOL VERDE & $F$ & $N$ & $Y$ & & & IV \\
\hline FUNGITOX & $F$ & $\mathbf{N}$ & $Y$ & & & III \\
\hline FUNGITOX 500 SC & $F$ & $Y$ & $\mathrm{~N}$ & . & III & \\
\hline FURADAN $100 \mathrm{G}$ & 1 & $N$ & $Y$ & II & & 1 \\
\hline FURADAN 350 SC & 1 & $Y$ & $Y$ & II & 1 & 1 \\
\hline FURADAN 350 TS & 1 & $Y$ & $Y$ & 11 & 1 & 1 \\
\hline FURADAN $50 \mathrm{G}$ & 1 & $Y$ & $Y$ & II & 1 & 1 \\
\hline FURAZIN 310 TS & 1 & $Y$ & $Y$ & II & 1 & 1 \\
\hline FURORE & $\mathrm{H}$ & $Y$ & $Y$ & 1 & II & III \\
\hline FURY $180 \mathrm{EW}$ & 1 & $N$ & $Y$ & II & & II \\
\hline FURY $200 \mathrm{EW}$ & 1 & $N$ & $Y$ & II & & III \\
\hline FUSIFLEX & $\mathrm{H}$ & $Y$ & $Y$ & NA & II & NA \\
\hline FUSILADE 125 & $\mathrm{H}$ & $Y$ & $Y$ & II & II & 11 \\
\hline FUSILADE 250 EW & $\mathrm{H}$ & $\mathrm{N}$ & $Y$ & II & & III \\
\hline
\end{tabular}


(continuação do Anexo II)

\begin{tabular}{|c|c|c|c|c|c|c|}
\hline PRODUTOS COMERCIAIS & USO & 1990 & 2000 & CPA & Ст90 & CT98 \\
\hline FUTUR 300 & 1 & $N$ & Y & III & . & III \\
\hline GALGOPER & 1 & $\mathrm{~N}$ & Y & & . & 1 \\
\hline GALGOTRIN & 1 & $\mathrm{~N}$ & $\mathrm{Y}$ & NA & . & II \\
\hline GALIGAN 240 CE & $\mathrm{H}$ & $N$ & Y & II &. & II \\
\hline GALLANT 240 BR & $\mathrm{H}$ & $Y$ & Y & NA & 1 & NA \\
\hline GALLERY & 1 & $\mathrm{~N}$ & $Y$ & & & III \\
\hline GAMIT & $\mathrm{H}$ & $Y$ & Y & II & 1 & II \\
\hline GAMIT $360 \mathrm{CS}$ & $\mathrm{H}$ & $N$ & $Y$ & III &. & III \\
\hline GARANT & $F$ & $N$ & Y & III &. & IV \\
\hline GARLON 480 & $\mathrm{H}$ & $\mathrm{N}$ & Y & NA &. & 11 \\
\hline GARLON 480 BR & $\mathrm{H}$ & $Y$ & $Y$ & NA & 11 & II \\
\hline GASTOXIN & 1 & $Y$ & $\mathrm{Y}$ & 1 & 1 & 1 \\
\hline GASTOXIN (PASTILHA DE 3g) & 1 & $N$ & $\bar{Y}$ & &. & 1 \\
\hline GASTOXIN (SACHET 34g) & 1 & $N$ & $Y$ & 1 & 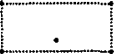 & 1 \\
\hline GASTOXIN PASTA & 1 & Y & Y & NA & 1 & NA \\
\hline GASTOXIN(PASTILHA DE 0,6g) & 1 & N & Y & & 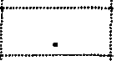 & 1 \\
\hline GAUCHO & 1 & $N$ & Y & III & . & IV \\
\hline GEMINI & 1 & $N$ & Y & II & & III \\
\hline GESAGARD 800 CIBA-GEIGY & $\mathrm{H}$ & $\mathrm{Y}$ & $\mathrm{N}$ & & III & \\
\hline GESAPAX 500 CIBA-GEIGY & $\mathrm{H}$ & $\mathrm{Y}$ & $Y$ & $\mathrm{NA}$ & III & NA \\
\hline GESAPAX 800 PM & $\mathrm{H}$ & $N$ & Y & NA & & III \\
\hline GESAPAX 800 PM CIBA-GEIGY & $\mathrm{H}$ & $Y$ & $Y$ & NA & III & III \\
\hline GESAPAX GRDA & $\mathrm{H}$ & $\mathrm{N}$ & $\mathrm{Y}$ & II & 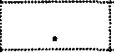 & IV \\
\hline GESAPRIM 500 CIBA-GEIGY & $\mathrm{H}$ & $\bar{Y}$ & $Y$ & 11 & III & NA \\
\hline GESAPRIM 800 PM & $\mathrm{H}$ & Y & $\mathbf{N}$ & & III & \\
\hline GESAPRIN GRDA & $\mathrm{H}$ & $\mathrm{N}$ & $Y$ & II & & III \\
\hline GESATOP 500 & $\mathrm{H}$ & Y & $N$ & & III & \\
\hline GESATOP 800 PM & $\mathrm{H}$ & Y & Y & NA & III & NA \\
\hline GESAVEROL 40 & 1 & Y & $Y$ & $N A$ & III & NA \\
\hline GLADIUM & $\mathrm{H}$ & $N$ & $Y$ & III & . & III \\
\hline GLIFOS & $\mathrm{H}$ & $\mathrm{N}$ & $Y$ & III &. & IV \\
\hline GLIFOSATO 480 AGRIPEC & $\mathrm{H}$ & $N$ & $Y$ & 11 & & IV \\
\hline GLIFOSATO FERSOL & $\mathrm{H}$ & Y & $Y$ & III & II & NA \\
\hline GLIFOSATO FERSOL 480 N.A. & $\mathrm{H}$ & $\mathrm{N}$ & $Y$ & & 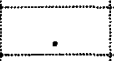 & III \\
\hline GLIFOSATO NORTOX & $\mathrm{H}$ & Y & $\mathrm{Y}$ & III & II & IV \\
\hline GLIFOSATO NORTOX N.A. & $\mathrm{H}$ & $\mathrm{N}$ & Y & III & 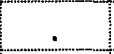 & IV \\
\hline GLION & $\mathrm{H}$ & $\mathbf{N}$ & $Y$ & II & & IV \\
\hline GLIPHOGAN 480 & $\mathrm{H}$ & $N$ & Y & III & . & III \\
\hline GLIZ $480 \mathrm{CS}$ & $\mathrm{H}$ & $\mathrm{N}$ & $Y$ & III & . & IV \\
\hline GOAL BR & $\mathrm{H}$ & Y & $Y$ & II & 11 & NA \\
\hline GOTAFIX & 0 & Y & $Y$ & NA & IV & NA \\
\hline
\end{tabular}


(continuação do Anexo II)

\begin{tabular}{|c|c|c|c|c|c|c|}
\hline PRODUTOS COMERCIAIS & USO & 1990 & 2000 & CPA & СТ90 & CT98 \\
\hline GRAMOCIL & $\mathrm{H}$ & Y & Y & II & 1 & NA \\
\hline GRAMOXONE 200 & $\mathrm{H}$ & $\mathrm{Y}$ & $\mathrm{Y}$ & 11 & 1 & NA \\
\hline GRANUTOX & $\mathrm{I}$ & $\mathrm{Y}$ & $\mathrm{Y}$ & NA & 1 & 1 \\
\hline GRANUTOX $150 \mathrm{G}$ & $\mathrm{I}$ & $N$ & $\mathrm{Y}$ & II & & 11 \\
\hline GRASCARB & $\mathrm{H}$ & $\mathrm{N}$ & $Y$ & 1 & & IV \\
\hline GRASLAN 100 PELETIZADO & $\mathrm{H}$ & $\mathrm{Y}$ & $\mathrm{Y}$ & NA & IIII & NA \\
\hline GRASLAN 200 PELETIZADO & $\mathrm{H}$ & $Y$ & $\mathrm{Y}$ & NA & III & III \\
\hline GRASLAN 400 PELETIZADO & $\mathrm{H}$ & $Y$ & $\mathrm{~N}$ & & III & \\
\hline GRASSAID & $\mathrm{H}$ & $Y$ & $\mathrm{Y}$ & NA & 11 & II \\
\hline GRASSAID $540 \mathrm{CE}$ & $\mathrm{H}$ & $\mathrm{N}$ & $Y$ & 1 & . & II \\
\hline GRAXOL & 1 & $\mathrm{~N}$ & $\mathrm{Y}$ & IV &. & IV \\
\hline GUNNER & $H$ & $\mathrm{~N}$ & $Y$ & II & 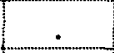 & 1 \\
\hline GUSATHION 400 & 1 & $\mathrm{Y}$ & $\mathrm{N}$ & . & 1 & \\
\hline HAMIDOP 600 & 1 & $\mathrm{~N}$ & $\mathrm{Y}$ & & & 1 \\
\hline HERBADOX $500 \mathrm{CE}$ & $H$ & $\mathrm{Y}$ & $Y$ & NA & 11 & III \\
\hline HERBAMINA BR & $\mathrm{H}$ & $\mathrm{Y}$ & $Y$ & NA & 1 & NA \\
\hline HERBANIL 368 & $\mathrm{H}$ & $N$ & $Y$ & NA &. & II \\
\hline HERBAZIN 500 BR & $H$ & $\mathrm{~N}$ & $Y$ & NA & . & III \\
\hline HERBI D-480 & $H$ & $Y$ & $Y$ & NA & 1 & NA \\
\hline HERBIFLAN & $\mathrm{H}$ & $\mathrm{Y}$ & $Y$ & II & II & II \\
\hline HERBIMIX SC & $\mathrm{H}$ & $Y$ & $Y$ & NA & III & NA \\
\hline HERBIPAK 500 BR & $\mathrm{H}$ & $Y$ & $Y$ & NA & III & III \\
\hline HERBI-PROPANIN & $\mathrm{H}$ & $N$ & Y & NA & 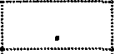 & II \\
\hline HERBIPROPANIN $450 \mathrm{CE}$ & $\mathrm{H}$ & $\mathrm{N}$ & $Y$ & & 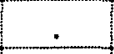 & 1 \\
\hline HERBITENSIL & 0 & $Y$ & $Y$ & NA & IV & NA \\
\hline HERBITRIN 500 BR & $\mathrm{H}$ & $N$ & $Y$ & NA & & III \\
\hline HERBURON 500 BR & $\mathrm{H}$ & $Y$ & $Y$ & NA & 11 & NA \\
\hline HIGHCROP $680 \mathrm{SC}$ & 1 & $N$ & $Y$ & IV & & IV \\
\hline HINOSAN 500 & $\mathrm{~F}$ & $Y$ & $Y$ & II & 1 & 1 \\
\hline HINOSAN $500 \mathrm{CE}$ & $F$ & $\mathrm{~N}$ & $Y$ & II & . & 1 \\
\hline HOEFIX & 0 & $N$ & $Y$ & NA & . & IV \\
\hline HOKKO CUPRA 500 & $F$ & $N$ & $Y$ & III & 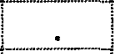 & IV \\
\hline HOKKO CYHEXATIN 500 & 1 & $Y$ & $\mathrm{~N}$ & & III & \\
\hline HOKKO HAITEN & 0 & $N$ & $Y$ & IV & & III \\
\hline HOKKO KASUMIN & $F$ & $Y$ & $Y$ & NA & III & NA \\
\hline HOKKO PLANTVAX 750 & $F$ & $Y$ & $Y$ & II & III & III \\
\hline HOKKO SUZU 200 & $F$ & $Y$ & $Y$ & NA & II & NA \\
\hline HOSTATHION 400 BR & 1 & $Y$ & $Y$ & II & 1 & 1 \\
\hline HYVAR 800 & $\mathrm{H}$ & $Y$ & $\mathrm{~N}$ & - & III & \\
\hline IHARA DIMETHOATE 500 & 1 & $Y$ & $\mathrm{~N}$ & & 1 & \\
\hline IHARAGUEN-S & 0 & $Y$ & $Y$ & IV & IV & IV \\
\hline
\end{tabular}


(continuação do Anexo II)

\begin{tabular}{|c|c|c|c|c|c|c|}
\hline PRODUTOS COMERCIAIS & Uso & 1990 & 2000 & CPA & CT90 & CT98 \\
\hline IHAROL & 1 & Y & $\mathrm{Y}$ & III & IV & IV \\
\hline ILOXAN CE & $\mathrm{H}$ & Y & $N$ & III & III & \\
\hline IMIDAN 500 PM & 1 & $Y$ & $Y$ & NA & II & II \\
\hline IMPACT & $\mathbf{F}$ & $\mathrm{N}$ & $Y$ & 11 & - & II \\
\hline INSECTO & 1 & $N$ & Y & IV & . & IV \\
\hline INTREPID 240 SC & 1 & $\mathbf{N}$ & Y & III & . & IV \\
\hline INVEST & $\mathrm{H}$ & $N$ & $Y$ & II &. & II \\
\hline ISATALONIL & $F$ & $Y$ & $Y$ & NA & II & NA \\
\hline ISATALONIL 500 SC & $\mathrm{F}$ & $\mathrm{Y}$ & $Y$ & NA & 1 & 1 \\
\hline ISCA 7 BELO & 1 & $Y$ & $N$ & $\cdot$ & II & 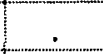 \\
\hline ISCA FERMEX & 1 & Y & $N$ & . & II & \\
\hline ISCA FORMICIDA AGROCERES & 1 & $\mathrm{Y}$ & $N$ & & II & \\
\hline ISCA FORMICIDA ATTA MEX-S & 1 & $N$ & $Y$ & III & . & IV \\
\hline ISCA FORMICIDA ATTA-MEX & 1 & $Y$ & $\mathrm{~N}$ & . & II & \\
\hline ISCA FORMICIDA LANDRIN & 1 & $N$ & $Y$ & II & & III \\
\hline ISCA FORMICIDA MIRIM & 1 & Y & $\mathrm{N}$ & 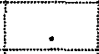 & II & \\
\hline ISCA FORMICIDA PYRINEX & 1 & $N$ & Y & II & & III \\
\hline ISCA FORMIFOS & 1 & $\mathrm{~N}$ & $Y$ & II & & III \\
\hline ISCA MIRENEX & 1 & $\mathrm{Y}$ & $\mathrm{N}$ & . & II &. \\
\hline ISCA TAMANDUA BANDEIRA & 1 & $Y$ & $\mathrm{~N}$ & & II & \\
\hline ISCA TAMANDUA BANDEIRA-S & 1 & $N$ & $Y$ & III & & IV \\
\hline ISOURON 400 & $\mathrm{H}$ & $\mathrm{N}$ & $Y$ & II & . & II \\
\hline JADE & $F$ & $\mathrm{~N}$ & $Y$ & II & & IV \\
\hline JOINT & 1 & $Y$ & Y & NA & IV & IV \\
\hline JUNO & $F$ & $\mathrm{~N}$ & Y & II & & III \\
\hline KABAT & 1 & $\mathrm{Y}$ & Y & NA & III & III \\
\hline KADETT CE & $\mathrm{H}$ & $N$ & $Y$ & 1 & & 1 \\
\hline KAETAN & 1 & $\mathrm{Y}$ & $\mathrm{N}$ & . & 11 & . \\
\hline KARATE 15 ED BICO AMARELO & 1 & $Y$ & $\mathrm{~N}$ & . & II & 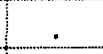 \\
\hline KARATE $50 \mathrm{CE}$ & 1 & $Y$ & $Y$ & 1 & II & II \\
\hline KARATE ZEON 250 CS & 1 & $\mathrm{~N}$ & Y &. & . & III \\
\hline KARATHANE CE & 1 & $N$ & $Y$ & 1 & 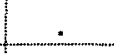 & 1 \\
\hline KARMEX & $\mathrm{H}$ & $Y$ & $Y$ & NA & IV & NA \\
\hline KARMEX $500 \mathrm{SC}$ & $\mathrm{H}$ & $Y$ & $Y$ & NA & II & II \\
\hline KARMEX 800 & $\mathrm{H}$ & $Y$ & $Y$ & NA & III & IV \\
\hline KATANA & $\mathrm{H}$ & $\mathrm{N}$ & $Y$ & III & & IV \\
\hline KELTHANE 480 & 1 & Y & Y & II & II & II \\
\hline KELTHANE CE & 1 & $Y$ & $\mathrm{~N}$ & 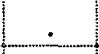 & 11 & \\
\hline KENDO $50 \mathrm{SC}$ & 1 & $N$ & $Y$ & 1 & & 11 \\
\hline KILVAL 300 & 1 & $Y$ & $Y$ & NA & 11 & III \\
\hline KITAZIN $480 \mathrm{CE}$ & $F$ & $Y$ & $\mathrm{~N}$ & 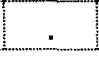 & 11 & . \\
\hline
\end{tabular}




\begin{tabular}{|c|c|c|c|c|c|c|}
\hline \multirow[b]{2}{*}{ PRODUTOS COMERCIAIS } & \multicolumn{6}{|c|}{ (continuação do Anexo II) } \\
\hline & USO & 1990 & 2000 & CPA & CT90 & CT98 \\
\hline KITAZIN GRANULAR & $\mathrm{F}$ & $\mathrm{Y}$ & $\mathrm{N}$ & . & III & \\
\hline KLAP & 1 & $\mathrm{~N}$ & $Y$ & . &. & 1 \\
\hline KLORPAN $480 \mathrm{CE}$ & 1 & $N$ & $Y$ & & & II \\
\hline K-OBIOL $2 \mathrm{P}$ & 1 & $\mathrm{Y}$ & $Y$ & II & IV & IV \\
\hline K-OBIOL 25 CE & 1 & Y & $Y$ & 1 & II & III \\
\hline KOBUTOL 750 & $\mathrm{~F}$ & $Y$ & $Y$ & NA & III & NA \\
\hline KOLOSSUS & $F$ & $\mathrm{Y}$ & $Y$ & $N A$ & IV & NA \\
\hline KONTROLE & $\mathrm{H}$ & $Y$ & $N$ & & II & \\
\hline K-OTHRINE $2 \mathrm{P}$ & 1 & $N$ & $Y$ & II & . & IV \\
\hline K-OTHRINE FORMICIDA 2P N.A. & 1 & $\mathrm{~N}$ & $Y$ & . & & IV \\
\hline KROVAR & $\mathrm{H}$ & $\mathrm{Y}$ & $\mathbf{N}$ & . & III & \\
\hline KROVAR BR & $\mathrm{H}$ & Y & $\mathbf{N}$ & . & III & $\cdot$ \\
\hline KUMULUSS & $F$ & $Y$ & $N$ & IV & IV & \\
\hline KUMULUS-DF & $\mathrm{F}$ & $N$ & $Y$ & IV & & IV \\
\hline KUMULUS-DF AG & $\mathrm{F}$ & $\mathrm{N}$ & $Y$ & IV & & IV \\
\hline LAEO CE & $\mathrm{H}$ & $\mathrm{Y}$ & $Y$ & II & 1 & II \\
\hline LAKREE FOGGING & 1 & $\mathrm{~N}$ & $Y$ & 1 & & III \\
\hline LANCE & $\mathrm{H}$ & $\mathrm{Y}$ & $\bar{Y}$ & NA & 1 & NA \\
\hline LANDRIN PO & 1 & Y & $N$ &. & II & \\
\hline LANNATE BR & 1 & $Y$ & $Y$ & NA & 1 & NA \\
\hline LANZAR & 0 & $N$ & $Y$ & IV &. & 11 \\
\hline LARVIN 350 RA & 1 & $Y$ & Y & NA & II & II \\
\hline LARVIN 800 WG & 1 & $N$ & $Y$ & III & & II \\
\hline LASER $100 \mathrm{G}$ & 1 & $N$ & $Y$ & III & . & III \\
\hline LASER $350 \mathrm{CE}$ & 1 & $Y$ & $N$ &. & 1 &. \\
\hline LASER $400 \mathrm{SC}$ & 1 & $N$ & $Y$ & II & . & II \\
\hline LEBAYCID 500 & 1 & $Y$ & $Y$ & NA & 11 & NA \\
\hline LEBAYCID PO & 1 & $Y$ & Y & II & III & III \\
\hline LENTAGRAN 450 CE & $\mathrm{H}$ & $\mathbf{N}$ & Y & II & & II \\
\hline LEPIDIN 600 & 1 & $Y$ & $N$ & & III & \\
\hline LESMICIDA PIKAPAU & 1 & $N$ & $Y$ & $N A$ & & III \\
\hline LESMIX & I & $\mathrm{Y}$ & $N$ & . & III & \\
\hline LEXONE SC & $\mathrm{H}$ & $\mathrm{Y}$ & $Y$ & NA & IV & NA \\
\hline LIFALIN BR & $\mathrm{H}$ & $Y$ & $Y$ & NA & II & NA \\
\hline LINUREX AGRICUR 500 PM & $\mathrm{H}$ & $N$ & $Y$ & NA & & III \\
\hline LORSBAN $10 \mathrm{G}$ & 1 & $\mathrm{~N}$ & $Y$ & II & & IV \\
\hline LORSBAN 240 UBV & 1 & $Y$ & $N$ & . & II & 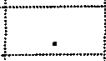 \\
\hline LORSBAN 480 BR & 1 & $Y$ & $Y$ & II & II & 11 \\
\hline MACHETE CE & $H$ & $Y$ & $Y$ & $\mathrm{NA}$ & II & II \\
\hline MALAFOG & 1 & $\mathrm{Y}$ & $\mathrm{N}$ & & II & \\
\hline MALAGRAN & 1 & $Y$ & $\mathrm{~N}$ & & III & \\
\hline
\end{tabular}




\begin{tabular}{|c|c|c|c|c|c|c|}
\hline PRODUTOS COMERCIAIS & USO & 1990 & 2000 & CPA & CT90 & CT98 \\
\hline MALATHION 40 PIKAPAU & 1 & $N$ & $\mathrm{Y}$ & III & & III \\
\hline MALATHION 500 CE PIKAPAU & 1 & $\mathrm{~N}$ & Y & III & 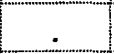 & III \\
\hline MALATHION 500 CE SULTOX & 1 & $Y$ & $Y$ & NA & III & NA \\
\hline MALATOL $1000 \mathrm{CE}$ & 1 & $Y$ & $Y$ & NA & II & 11 \\
\hline MALATOL $20 \mathrm{P}$ & 1 & $Y$ & $Y$ & NA & III & III \\
\hline MALATOL 250 & 1 & $Y$ & $Y$ & NA & III & NA \\
\hline MALATOL 250 PM & 1 & $Y$ & $\mathrm{~N}$ & & III & \\
\hline MALATOL $40 \mathrm{P}$ & 1 & Y & $Y$ & NA & III & IV \\
\hline MALATOL $500 \mathrm{CE}$ & 1 & $Y$ & $Y$ & $\mathrm{NA}$ & III & III \\
\hline MALATOL UBV & 1 & Y & $Y$ & NA & III & III \\
\hline MANCOZEB SANACHEN 800 PM & $F$ & $\mathrm{~N}$ & Y & II & . & II \\
\hline MANNEJO & $\mathrm{H}$ & $\mathrm{N}$ & $Y$ & 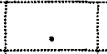 & 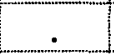 & 1 \\
\hline MANZATE 800 & $F$ & $\mathrm{~N}$ & $Y$ & NA &. & III \\
\hline MANZATE BR & $\mathrm{F}$ & $\mathrm{Y}$ & $\mathrm{N}$ & . & III & \\
\hline MARCAP CE & $\mathrm{H}$ & $\mathrm{Y}$ & $Y$ & II & II & II \\
\hline MARSHAL 200 SC & 1 & $\mathrm{~N}$ & $Y$ & II & & 11 \\
\hline MARSHAL $250 \mathrm{CE}$ & 1 & Y & $\mathrm{N}$ & . & 1 & 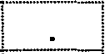 \\
\hline MARSHAL 250 TS & 1 & $Y$ & $N$ & 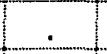 & II & \\
\hline MARSHAL 350 TS & 1 & $Y$ & $Y$ & NA & II & II \\
\hline MARSHAL $50 \mathrm{G}$ & 1 & $Y$ & $Y$ & II & III & III \\
\hline MARSHAL T.S & 1 & $\mathrm{~N}$ & $Y$ & II &. & II \\
\hline MARZINC 250 TS & 1 & $\mathrm{~N}$ & $Y$ & II &. & II \\
\hline MATCH CE & 1 & $\mathrm{~N}$ & $\mathrm{Y}$ & II & . & IV \\
\hline MAVRIK & 1 & $Y$ & $Y$ & 11 & 1 & 1 \\
\hline MAVRIK AQUAFLOW & 1 & $Y$ & $Y$ & NA & 11 & NA \\
\hline MAX OLEO & 0 & $N$ & $Y$ & IV &. & IV \\
\hline MAXIM & $F$ & $\mathrm{~N}$ & Y & III & & IV \\
\hline MAYRAN & $F$ & $Y$ & $Y$ & NA & III & NA \\
\hline MELPREX 650 PM & $F$ & $Y$ & $Y$ & NA & II & NA \\
\hline MENTOX $600 \mathrm{CE}$ & 1 & $N$ & $Y$ & NA & 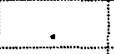 & 1 \\
\hline MEOTHRIN 300 & 1 & $\mathrm{~N}$ & $Y$ & II & . & 1 \\
\hline MERTIN 400 & $\mathrm{~F}$ & Y & $\bar{Y}$ & II & 1 & NA \\
\hline MESUROL 500 SC & 1 & $\mathrm{~N}$ & $Y$ & II &. & II \\
\hline METAFOS & 1 & $\mathrm{~N}$ & $Y$ & 1 & & 1 \\
\hline METAMIDOFOS 600 DEFENSA & 1 & $Y$ & $Y$ & NA & 1 & NA \\
\hline METAMIDOFOS FERSOL 600 & 1 & $\mathrm{~N}$ & Y & II & & II \\
\hline METASIP & 1 & $\mathrm{~N}$ & $Y$ & NA & & 1 \\
\hline METASYSTOX (I) CE 250 & 1 & Y & $N$ & 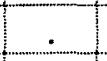 & 1 & 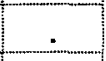 \\
\hline METHIL PARATHION 600 CE INSETICIDA AGROCERES & 1 & Y & Y & NA & 1 & 1 \\
\hline METHOMEX 215 LS & 1 & $\mathrm{~N}$ & Y & II & & II \\
\hline METILTIOFAN & $F$ & $\mathrm{Y}$ & $\bar{Y}$ & NA & IV & NA \\
\hline
\end{tabular}


(continuação do Anexo II)

\begin{tabular}{|c|c|c|c|c|c|c|}
\hline PRODUTOS COMERCIAIS & USO & 1990 & 2000 & CPA & CT90 & CT98 \\
\hline METRIMEX $500 \mathrm{SC}$ & $\mathrm{H}$ & $N$ & $Y$ & NA & 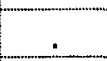 & III \\
\hline MICRONOL 810 PM & 1 & $N$ & $Y$ & IV & & IV \\
\hline MICROSULFAN 800 PM & 1 & Y & $Y$ & IV & IV & IV \\
\hline MICROTHIOL 750 SC & $F$ & $Y$ & $\mathrm{~N}$ & & IV & \\
\hline MICROZOL & $F$ & $Y$ & $Y$ & NA & IV & NA \\
\hline MILDEX BR & $F$ & $Y$ & $Y$ & NA & IV & NA \\
\hline MIMIC 240 SC & 1 & $\mathrm{~N}$ & $Y$ & III & & IV \\
\hline MIREX & 1 & $Y$ & $\mathrm{~N}$ & & II & \\
\hline MIREX-S & 1 & $\mathrm{~N}$ & $Y$ & III & 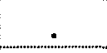 & IV \\
\hline MIREX-S MAX & 1 & $\mathrm{~N}$ & $Y$ & III & . & IV \\
\hline MODDUS & 0 & $N$ & $Y$ & 11 & 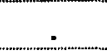 & III \\
\hline MONCEREN PM & $\mathrm{F}$ & $\mathbf{N}$ & $Y$ & II & . & IV \\
\hline MONITRAP & 1 & $N$ & $Y$ & IV & 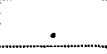 & III \\
\hline MORESTAN 500 SC & 1 & $Y$ & N & & II & \\
\hline MORESTAN 700 & 1 & $N$ & $Y$ & II & & II \\
\hline MORESTAN BR & 1 & $Y$ & $Y$ & II & III & NA \\
\hline MOSPILAN & 1 & $\mathrm{~N}$ & Y & II &. & III \\
\hline MSMA SANACHEN 720 CS & $\mathrm{H}$ & $\mathrm{N}$ & $Y$ & 11 & & III \\
\hline MYCOSHIELD & $F$ & $Y$ & Y & NA & II & NA \\
\hline MYTHOS & $F$ & $N$ & Y & II &. & III \\
\hline NALED 860 & 1 & $N$ & $Y$ & 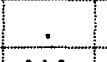 & . & II \\
\hline NATUR'L OLEO & 1 & $N$ & $Y$ & NA & 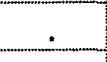 & IV \\
\hline N-DEC & 0 & $Y$ & $N$ & & III & es \\
\hline NEMACUR & 1 & $Y$ & $Y$ & II & 1 & 1 \\
\hline NEMACUR CE & 1 & $Y$ & $Y$ & 1 & 1 & 1 \\
\hline NEORON 500 CE & 1 & $Y$ & $\mathrm{Y}$ & NA & III & IV \\
\hline NETUN $800 \mathrm{SC}$ & $\mathrm{H}$ & $N$ & $\mathrm{Y}$ & 11 & 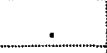 & III \\
\hline NIMBUS & 0 & $\mathrm{~N}$ & $\mathrm{Y}$ & III & . & IV \\
\hline NITROSIL $600 \mathrm{CE}$ & 1 & $\mathrm{~N}$ & $\mathrm{Y}$ & NA & . & 1 \\
\hline NOCAUTE & 1 & $\mathrm{~N}$ & $Y$ & 11 & . & II \\
\hline NOMINEE $400 \mathrm{SC}$ & $\mathrm{H}$ & $\mathrm{N}$ & $Y$ & III & . & 11 \\
\hline NOMOLT 150 & 1 & $N$ & $\bar{Y}$ & 11 & . & IV \\
\hline NOR-TRIN $250 \mathrm{CE}$ & 1 & $Y$ & $Y$ & NA & II & NA \\
\hline NOVOLATE & $\mathrm{H}$ & $\mathrm{N}$ & $Y$ & II & & 1 \\
\hline NURELLE $250 \mathrm{CE}$ & 1 & $Y$ & $\mathrm{~N}$ & & II & \\
\hline NUTRIXOFRE 800 & $\mathrm{~F}$ & $\mathrm{~N}$ & $Y$ & IV & 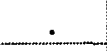 & IV \\
\hline NUVACRON 250 UBV BR & 1 & $Y$ & $\mathrm{~N}$ & & 1 & \\
\hline NUVACRON 400 & 1 & $Y$ & $Y$ & 11 & 1 & NA \\
\hline NUVAN $1000 \mathrm{CE}$ & 1 & $Y$ & $N$ &. & 1 & \\
\hline OFUNACK $400 \mathrm{CE}$ & 1 & $N$ & $Y$ & II & & III \\
\hline OLEO MINERAL FERSOL & 1 & $Y$ & $Y$ & IV & IV & IV \\
\hline
\end{tabular}


(continuação do Anexo II)

\begin{tabular}{|c|c|c|c|c|c|c|}
\hline PRODUTOS COMERCIAIS & Uso & 1990 & 2000 & CPA & CT90 & CT98 \\
\hline OLEO VEGETAL NORTOX & 1 & $\mathrm{~N}$ & $\mathrm{Y}$ & IV & & IV \\
\hline OMITE 300 PM & 1 & $\mathrm{~N}$ & $\mathrm{Y}$ & II & & II \\
\hline OMITE 300 PM BR & 1 & $Y$ & $\mathrm{~N}$ & $x^{*}$ & II & \\
\hline OMITE $720 \mathrm{CE}$ & 1 & $\mathrm{~N}$ & $Y$ & & & II \\
\hline OMITE 720 CE BR & 1 & $Y$ & Y & NA & III & NA \\
\hline ONCOL 10 G SIPCAM & 1 & $N$ & $Y$ & III & . & III \\
\hline ONCOL SIPCAM & 1 & $N$ & $Y$ & II &. & II \\
\hline ONDUTY & $\mathrm{H}$ & $\mathrm{N}$ & $Y$ & & . & III \\
\hline OPPABR CE & 1 & $N$ & $Y$ & NA & & IV \\
\hline OPUS & $F$ & $N$ & $Y$ & II & 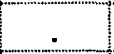 & 1 \\
\hline ORDRAM $200 \mathrm{GR}$ & $\mathrm{H}$ & $Y$ & $Y$ & NA & III & NA \\
\hline ORDRAM $720 \mathrm{CE}$ & $\mathrm{H}$ & $Y$ & $Y$ & NA & II & NA \\
\hline ORDRAM GR & $\mathrm{H}$ & $\bar{Y}$ & $Y$ & NA & III & NA \\
\hline ORIUS $250 \mathrm{CE}$. & $F$ & $\mathrm{~N}$ & $Y$ & III & & III \\
\hline ORTHENE $750 \mathrm{BR}$ & 1 & Y & $Y$ & III & III & IV \\
\hline ORTHENE 750 BR PARA SEMENTES & 1 & Y & $Y$ & III & III & IV \\
\hline ORTHO HAMIDOP 600 & 1 & $\mathrm{Y}$ & Y & NA & 1 & NA \\
\hline ORTHO NALED 860 & 1 & $\mathrm{Y}$ & $\mathrm{Y}$ & NA & II & NA \\
\hline ORTHOCIDE 500 & $F$ & $\mathrm{Y}$ & $\mathrm{N}$ &. & IIII & \\
\hline ORTUS $50 \mathrm{SC}$ & 1 & $\mathrm{~N}$ & $\mathrm{Y}$ & 1 & . & II \\
\hline PACTO & $\mathrm{H}$ & $\mathrm{N}$ & Y & III & . & III \\
\hline PADRON & $\mathrm{H}$ & $\mathrm{N}$ & Y & II & . & III \\
\hline PALISADE & $\mathrm{F}$ & $\mathrm{N}$ & $Y$ & II & - & III \\
\hline PANOCTINE PO & $\mathrm{F}$ & $N$ & $Y$ & NA & & III \\
\hline PANTHER $120 \mathrm{CE}$ & $\mathrm{H}$ & $\mathrm{N}$ & $Y$ & II & . & 1 \\
\hline PARATHION 600 CE PIKAPAU & 1 & $\mathrm{~N}$ & $Y$ & NA & & 1 \\
\hline PARSEC & 1 & $\mathrm{~N}$ & Y & II & & III \\
\hline PARTNER & 1 & Y & $Y$ & NA. & III & IV \\
\hline PAX-HCE & $\mathrm{H}$ & Y & $Y$ & NA & II & II \\
\hline PAXPLUS & $\mathrm{H}$ & Y & $N$ & 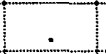 & II & \\
\hline PAXPRIM PM & $\mathrm{H}$ & $\mathrm{Y}$ & $\mathrm{Y}$ & NA & III & $\mathrm{NA}$ \\
\hline PECENOL PM & $F$ & Y & $N$ & & III & \\
\hline PENDINIL & $\mathrm{H}$ & $\mathrm{Y}$ & $\mathrm{Y}$ & NA & II & II \\
\hline PEPROSAN & $F$ & $\mathrm{Y}$ & $N$ & . & II & \\
\hline PERFEKTHION & 1 & $Y$ & $Y$ & II & 1 & NA \\
\hline PERFLAN 800 BR & $\mathrm{H}$ & $N$ & $Y$ & II & 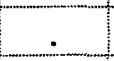 & III \\
\hline PERFORM $360 \mathrm{CE}$ & $\mathrm{H}$ & $Y$ & $\mathrm{~N}$ & 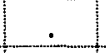 & II & \\
\hline PERMETRINA FERSOL 384 CE & 1 & Y & Y & II & II & 1 \\
\hline PERSIST SC & $F$ & $N$ & $Y$ & NA & . & III \\
\hline PHOSDRIN $185 \mathrm{CE}$ & 1 & $Y$ & $Y$ & NA & 1 & 1 \\
\hline PHOSTEK (PASTILHA DE $0.6 \mathrm{~g}$ ) & 1 & N & $Y$ &. & . & 1 \\
\hline
\end{tabular}


(continuação do Anexo II)

\begin{tabular}{|c|c|c|c|c|c|c|}
\hline PRODUTOS COMERCIAIS & USO & 1990 & 2000 & CPA & Ст90 & CT98 \\
\hline PHOSTEK (PASTILHA DE 3g) & 1 & $N$ & $\bar{Y}$ & & & 1 \\
\hline PHOSTEK (SACHET 34g) & 1 & $\mathrm{~N}$ & Y & & 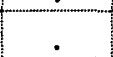 & 1 \\
\hline PHOTON & $F$ & $\mathrm{~N}$ & $\mathrm{Y}$ & III & . & IV \\
\hline PIRATE & 1 & $\mathrm{~N}$ & $\mathrm{Y}$ & II & & III \\
\hline PIREDAN & 1 & $\mathrm{Y}$ & Y & 1 & II & II \\
\hline PIREPHOS CE & 1 & $\mathrm{~N}$ & Y & II & & II \\
\hline PI-RIMOR 500 PM & 1 & $\bar{Y}$ & $\mathrm{Y}$ & NA & II & NA \\
\hline PIVOT & $\mathrm{H}$ & $\mathrm{N}$ & $\mathrm{Y}$ & NA & & IV \\
\hline PIVOT 70 DG & $H$ & $\mathrm{~N}$ & $Y$ & & . & III \\
\hline PIX & 0 & $\mathrm{~N}$ & $Y$ & III & & IV \\
\hline PLANTACOL & $F$ & $Y$ & $\mathrm{Y}$ & III & III & III \\
\hline PLANTVAX 750 PM BR & $\mathrm{F}$ & $\mathrm{Y}$ & $Y$ & $\mathrm{NA}$ & III & NA \\
\hline PLATEAU & $\mathrm{H}$ & $\mathrm{N}$ & $\mathrm{Y}$ & III & & III \\
\hline PLENUM & $H$ & $\mathrm{~N}$ & $Y$ & II & . & II \\
\hline POAST & $\mathrm{H}$ & $\mathrm{N}$ & $Y$ & NA & 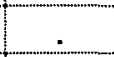 & II \\
\hline POAST BASF & $\mathrm{H}$ & $Y$ & $\mathrm{Y}$ & NA & II & NA \\
\hline PODIUM & $\mathrm{H}$ & $Y$ & $Y$ & II & III & III \\
\hline PODIUM S & $\mathrm{H}$ & $\mathrm{N}$ & Y & III & & II \\
\hline POLO 500 PM & 1 & $\mathrm{~N}$ & $Y$ & II & & 1 \\
\hline POLYDIAL CE & 1 & $\mathrm{Y}$ & $\mathrm{N}$ & & II & \\
\hline POLYDIAL UBV & 1 & $Y$ & $\mathrm{~N}$ & & II & \\
\hline POLYTRIN 400/40 CE & 1 & Y & $\mathrm{Y}$ & NA & II & NA \\
\hline POSMAT & $\mathrm{H}$ & $\mathrm{Y}$ & $\mathrm{N}$ & & II & \\
\hline POSMIL & $\mathrm{H}$ & $\mathrm{N}$ & $Y$ & II & & IV \\
\hline POSSE 200 ED BICO BRANCO & 1 & $\mathrm{Y}$ & $\mathrm{N}$ & & II & \\
\hline POUNCE 250 SC & 1 & $\mathrm{~N}$ & $Y$ & II & & IV \\
\hline POUNCE 384 CE & 1 & $\mathrm{Y}$ & $\mathrm{Y}$ & II & II & NA \\
\hline PRAMATO & $\mathrm{H}$ & $Y$ & Y & III & 1 & 1 \\
\hline PREGLONE & $\mathrm{H}$ & $Y$ & $\mathrm{~N}$ & & 1 & \\
\hline PREMERLIN $600 \mathrm{CE}$ & $\mathrm{H}$ & $Y$ & $Y$ & NA & II & NA \\
\hline PREMERLIN N.A. & $\mathrm{H}$ & $\mathrm{N}$ & $Y$ & & & 11 \\
\hline PREMIS & $\mathrm{F}$ & $\mathrm{N}$ & $Y$ & & & IV \\
\hline PREP & 0 & $\mathrm{~N}$ & $Y$ & III & & II \\
\hline PREVICUR N & $\mathrm{F}$ & $Y$ & $Y$ & III & III & NA \\
\hline PRIMAIZ & $\mathrm{H}$ & $Y$ & $\mathrm{~N}$ & & II & \\
\hline PRIMAIZ 500 SC & $\mathrm{H}$ & $\mathrm{N}$ & $Y$ & 1 & & III \\
\hline PRIMATOL & $\mathrm{H}$ & $Y$ & $\mathrm{~N}$ & & III & \\
\hline PRIMATOP & H & $Y$ & $\mathrm{~N}$ & & III & \\
\hline PRIMATOP SC & $\mathrm{H}$ & $Y$ & $\mathrm{~N}$ & & III & \\
\hline PRIME PLUS & 0 & $Y$ & $\mathrm{~N}$ & & II & \\
\hline PRIMESTRA GOLD & $\mathrm{H}$ & $\mathrm{N}$ & $\mathrm{Y}$ & II & & II \\
\hline
\end{tabular}


(continuação do Anexo II)

\begin{tabular}{|c|c|c|c|c|c|c|}
\hline PRODUTOS COMERCIAIS & Uso & 1990 & 2000 & CPA & CT90 & СТ98 \\
\hline PRIMESTRA SC & $\mathrm{H}$ & $\mathrm{Y}$ & $\mathrm{N}$ & & II & \\
\hline PRIMOLEO & $\mathrm{H}$ & $Y$ & $Y$ & II & III & IV \\
\hline PRIORI & $\mathrm{F}$ & $\mathrm{N}$ & $Y$ & III & . & III \\
\hline PRO-GIBB & 0 & $\mathrm{~N}$ & $Y$ & IV & . & IV \\
\hline PROMET & 1 & $Y$ & $Y$ & NA & 1 & 1 \\
\hline PROMET $400 \mathrm{CS}$ & 1 & $N$ & $Y$ & II & . & III \\
\hline PROOF & $\mathrm{H}$ & $\mathrm{N}$ & Y & II & . & IV \\
\hline PROPANIL 360 AGRIPEC & $\mathrm{H}$ & $\mathrm{N}$ & Y & NA & . & II \\
\hline PROPANIL DEFENSA & $\mathrm{H}$ & Y & $Y$ & NA & II & NA \\
\hline PROPANIL FERSOL $360 \mathrm{CE}$ & $\mathrm{H}$ & $Y$ & $Y$ & NA & II & NA \\
\hline PROPANIL ICI 360 CE & $\mathrm{H}$ & Y & $Y$ & NA & II & II \\
\hline PROPANIL MILENIA & $\mathrm{H}$ & $\mathrm{N}$ & Y & . &. & II \\
\hline PROPANIN & $H$ & $\mathrm{~N}$ & $Y$ & 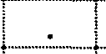 & 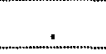 & II \\
\hline PROPANIN 450 & $\mathrm{H}$ & Y & Y & NA & II & II \\
\hline PROPANIN CNDA & $\mathrm{H}$ & $Y$ & $\mathrm{~N}$ &. & III & \\
\hline PROPARGITE FERSOL $720 \mathrm{CE}$ & 1 & $Y$ & $Y$ & NA & 11 & NA \\
\hline PROPOSE & $F$ & $\mathrm{~N}$ & Y & III & & IV \\
\hline PROSTORE $25 \mathrm{CE}$ & 1 & $\mathrm{~N}$ & Y & II & & III \\
\hline PROTEGE & 1 & $\mathrm{~N}$ & Y & IV & 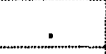 & IV \\
\hline PROVADO & 1 & $\mathrm{~N}$ & Y & III & . & IV \\
\hline PROVENCE $750 \mathrm{WG}$ & $\mathrm{H}$ & $\mathrm{N}$ & Y & II & . & III \\
\hline QUATERMON & $\mathrm{F}$ & $\mathbf{N}$ & Y & NA & . & IV \\
\hline RADIANT 100 & $\mathrm{H}$ & $\mathrm{N}$ & Y & 1 & 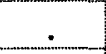 & 1 \\
\hline RALZER 350 SC & 1 & $Y$ & $\mathrm{~N}$ & & 1 & \\
\hline RALZER 50 GR & 1 & $Y$ & $Y$ & NA & 1 & NA \\
\hline RAMEXANE 850 PM & $F$ & Y & $Y$ & NA & IV & NA \\
\hline RAPID & 1 & Y & $Y$ & NA & IV & IV \\
\hline RAPTOR 70 DG & $\mathrm{H}$ & $N$ & $Y$ & III &. & III \\
\hline RAXIL 25 & $F$ & $Y$ & Y & NA & III & III \\
\hline RECONIL & $F$ & Y & Y & III & IV & NA \\
\hline RECOP & $\mathrm{F}$ & Y & Y & III & IV & NA \\
\hline RECOP SC & $F$ & $Y$ & Y & NA & IV & NA \\
\hline REDSHIELD 750 & $F$ & $N$ & $\mathrm{Y}$ & III & . & IV \\
\hline REGENT $20 \mathrm{G}$ & 1 & $N$ & $Y$ & 11 & & IV \\
\hline REGENT 800 WG & 1 & $N$ & $Y$ & II & . & II \\
\hline REGLONE & $\mathrm{H}$ & $Y$ & $Y$ & NA & $\underline{11}$ & NA \\
\hline RESIST & $\mathrm{F}$ & $\mathrm{N}$ & Y & II & 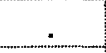 & 11 \\
\hline RHOCAP & 1 & $\mathrm{~N}$ & $\mathrm{Y}$ & NA & . & 1 \\
\hline RHODIAURAM 700 & $F$ & $Y$ & $Y$ & 1 & III & III \\
\hline RHODIAURAM SC & $F$ & $\mathrm{~N}$ & Y & 1 & & III \\
\hline RIDOMIL - MANCOZEB BR & $F$ & Y & $N$ & . & III & 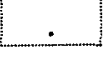 \\
\hline
\end{tabular}


(continuação do Anexo II)

\begin{tabular}{|c|c|c|c|c|c|c|}
\hline PRODUTOS COMERCIAIS & USO & 1990 & 2000 & CPA & CT90 & CT98 \\
\hline RIDOMIL 250 PM & $F$ & $\mathrm{Y}$ & $Y$ & NA & III & NA \\
\hline RIDOMIL 50 GR & $\mathrm{F}$ & $\mathrm{N}$ & $\mathrm{Y}$ & II & & IV \\
\hline RIDOXYLPM & $F$ & $\mathrm{Y}$ & $\mathrm{N}$ & 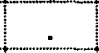 & II & \\
\hline RIPCORD 100 & 1 & $N$ & Y & 1 & . & 11 \\
\hline RIPCORD 100 SC & 1 & $N$ & Y & II & . & II \\
\hline RIPCORD 20 UBV & 1 & $N$ & $Y$ & 1 & . & II \\
\hline ROBUST & $\mathrm{H}$ & $N$ & $Y$ & 1 & . & III \\
\hline RODEO & $\mathrm{H}$ & $\mathrm{Y}$ & $Y$ & III & III & IV \\
\hline RODEO N.A. & $\mathrm{H}$ & $N$ & $Y$ & III & & IV \\
\hline RODISAN SC & $F$ & $\mathrm{Y}$ & $Y$ & NA & III & NA \\
\hline RONILAN & $F$ & $N$ & $Y$ & II & & III \\
\hline RONILAN 500 & $F$ & $Y$ & $\mathbf{N}$ & & III & \\
\hline RONSTAR $250 \mathrm{BR}$ & $\mathrm{H}$ & $Y$ & $Y$ & NA & II & NA \\
\hline RONSTAR SC & $\mathrm{H}$ & $Y$ & Y & NA & III & NA \\
\hline ROUNDUP & $\mathrm{H}$ & $Y$ & $Y$ & II & II & IV \\
\hline ROUNDUP MULTIACAO & $\mathrm{H}$ & $\mathrm{N}$ & Y & III & . & IV \\
\hline ROUNDUP N.A. & $\mathrm{H}$ & $\mathrm{N}$ & $Y$ & II & . & IV \\
\hline ROUNDUP ORIGINAL & $\mathrm{H}$ & $\mathrm{N}$ & $\mathrm{Y}$ & II & . & IV \\
\hline ROUNDUP TRANSORB & $\mathrm{H}$ & $\mathrm{N}$ & $Y$ & IIII & . & III \\
\hline ROUNDUP WG & $H$ & $\mathrm{~N}$ & $Y$ & II & . & IV \\
\hline ROUNDUP WG BR & $\mathrm{H}$ & $N$ & $Y$ & III & & IV \\
\hline ROVRAL & $F$ & Y & $Y$ & II & IV & IV \\
\hline ROVRAL SC & $F$ & $Y$ & $Y$ & III & IV & IV \\
\hline ROVRIN & $F$ & $Y$ & $Y$ & NA & III & NA \\
\hline ROYAL MH & 0 & $\mathbf{N}$ & $Y$ &. & . & II \\
\hline ROYAL MH-30 BR & 0 & $Y$ & $N$ & & II & \\
\hline ROYALTAC BR & 0 & Y & $\mathrm{N}$ & & III & \\
\hline RUBIGAN $120 \mathrm{CE}$ & $\mathrm{F}$ & $Y$ & $Y$ & NA & II & NA \\
\hline RUFAST 50 SC & 1 & $N$ & $Y$ & 1 & 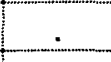 & IV \\
\hline SABRE & 1 & $N$ & Y & II & & III \\
\hline SANAGRAN & 1 & $Y$ & $\mathrm{~N}$ & 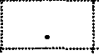 & III &. \\
\hline SANDOVIT & 0 & $Y$ & $Y$ & IV & IV & IV \\
\hline SANMITE & 1 & $\mathrm{~N}$ & $\mathrm{Y}$ & 1 & . & 1 \\
\hline SANSON 40 SC & $\mathrm{H}$ & $N$ & $Y$ & 11 &. & IV \\
\hline SAPROL & $F$ & $Y$ & $Y$ & NA & II & NA \\
\hline SATANIL CE & $\mathrm{H}$ & $Y$ & $Y$ & NA & III & III \\
\hline SATURN $500 \mathrm{CE}$ & $H$ & $\mathrm{~N}$ & $Y$ & 1 & 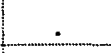 & $\|$ \\
\hline SATURN GR 100 & $\mathrm{H}$ & $Y$ & $Y$ & 1 & IV & IV \\
\hline SAURUS & 1 & $N$ & $Y$ & 11 & & III \\
\hline SAVEY PM & 1 & Y & Y & NA & III & NA \\
\hline SCEPTER & $\mathrm{H}$ & $Y$ & $Y$ & III & III & IV \\
\hline
\end{tabular}


(continuação do Anexo II)

\begin{tabular}{|c|c|c|c|c|c|c|}
\hline PRODUTOS COMERCIAIS & USO & 1990 & 2000 & CPA & CT90 & CT98 \\
\hline SCEPTER 70 DG & $\mathrm{H}$ & $\mathrm{N}$ & $\mathrm{Y}$ & III & . & III \\
\hline SCORE & $\mathrm{F}$ & $N$ & $Y$ & II & . & 1 \\
\hline SCORPION & $H$ & $\mathrm{~N}$ & $\mathrm{Y}$ & III & & IV \\
\hline SCOUT N.A. & $H$ & $N$ & Y & 11 & & IV \\
\hline SECAFIX 850 & $H$ & Y & $Y$ & 1 & III & III \\
\hline SECAMATO & $\mathrm{H}$ & Y & $Y$ & NA & 1 & 1 \\
\hline SELECT $240 \mathrm{CE}$ & $H$ & $\mathrm{~N}$ & $\mathrm{Y}$ & III & & III \\
\hline SEMEVIN 350 RA & 1 & $\mathrm{Y}$ & $Y$ & 1 & II & III \\
\hline SEMPRA & $\mathrm{H}$ & $N$ & $Y$ & III & & III \\
\hline SENCOR 480 & $H$ & $Y$ & $\mathrm{Y}$ & II & IV & IV \\
\hline SENCOR BR & $\mathrm{H}$ & $Y$ & $Y$ & II & IV & IV \\
\hline SERRICORNIN FERSOL & 1 & $N$ & $Y$ & IV & & III \\
\hline SEVIN 480 SC & 1 & $Y$ & $Y$ & NA & 11 & II \\
\hline SEVIN 50 & 1 & $Y$ & $\mathrm{~N}$ & . & III & \\
\hline SEVIN 75 & 1 & $Y$ & $\mathrm{Y}$ & NA & III & NA \\
\hline SEVIN 850 PM & 1 & $Y$ & $\mathrm{~N}$ & . & II & \\
\hline SHELLVIN 500 SC & 1 & $Y$ & $\mathrm{~N}$ &. & III &. \\
\hline SHERPA 200 & 1 & $\mathrm{~N}$ & $Y$ & NA & . & 11 \\
\hline SHOGUM $100 \mathrm{CE}$ & $\mathrm{H}$ & $\mathrm{N}$ & $Y$ & 11 & . & III \\
\hline SIALEX 500 & $\mathrm{~F}$ & $\mathrm{~N}$ & $Y$ & II & - & II \\
\hline SILWETT L-77 AG & 0 & $\mathrm{~N}$ & Y & III &. & II \\
\hline SIMANEX 500 SC & $\mathrm{H}$ & $N$ & $Y$ & IV & . & III \\
\hline SIMAZINAX SC & $\mathrm{H}$ & Y & Y & NA & III & NA \\
\hline SINBAR 800 & $\mathrm{H}$ & $Y$ & $N$ & & III & \\
\hline SINERGE CE & $\mathrm{H}$ & $N$ & Y & II & & II \\
\hline SIPAZINA 800 PM & $\mathrm{H}$ & $Y$ & Y & NA & III & NA \\
\hline SIPCAMOIL & 1 & $Y$ & $N$ & & IV & \\
\hline SIPCATIN 500 SC & 1 & $Y$ & $Y$ & NA & III & NA \\
\hline SIPTRAN 500 SC & $\mathrm{H}$ & $Y$ & $Y$ & III & III & NA \\
\hline SIRIUS 250 SC & $\mathrm{H}$ & $N$ & $Y$ & III &. & IV \\
\hline SMART & $\mathrm{H}$ & $\mathrm{N}$ & $Y$ & III & . & III \\
\hline SMASH & $\mathrm{H}$ & $N$ & $Y$ & NA &. & 1 \\
\hline SOLVIREX $250 \mathrm{CE}$ & 1 & $Y$ & $Y$ & NA & 1 & 1 \\
\hline SOLVIREX GR 100 & 1 & $Y$ & $Y$ & II & 1 & III \\
\hline SOLVIREX GR 50 & 1 & $Y$ & $\mathrm{~N}$ & 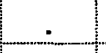 & 1 & \\
\hline SPARK CE & $\mathrm{H}$ & $Y$ & $N$ & 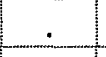 & II & \\
\hline SPECTRO & $\mathrm{F}$ & $\mathrm{N}$ & $Y$ & II & . & III \\
\hline SPIDER 840 GRDA & $\mathrm{H}$ & $\mathrm{N}$ & $Y$ & III & . & II \\
\hline SPINNER & 1 & $N$ & Y & & . & IV \\
\hline SPORTAK $450 \mathrm{CE}$ & $\mathrm{F}$ & $\mathrm{N}$ & Y & II &. & 1 \\
\hline SQUADRON & $\mathrm{H}$ & $\mathrm{N}$ & Y & 1 & . & III \\
\hline
\end{tabular}




\begin{tabular}{|c|c|c|c|c|c|c|}
\hline \multirow{2}{*}{ PRODUTOS COMERCIAIS } & \multicolumn{6}{|c|}{ (continuação do Anexo II } \\
\hline & USO & 1990 & 2000 & CPA & CT90 & CT98 \\
\hline STAM 360 & $\mathrm{H}$ & $Y$ & $Y$ & NA & II & II \\
\hline STAM 480 & $\mathrm{H}$ & $\mathrm{Y}$ & $\mathrm{Y}$ & NA & II & II \\
\hline STAM 800 GD & $\mathrm{H}$ & $N$ & $Y$ & II & . & II \\
\hline STAM BR & $\mathrm{H}$ & $Y$ & $N$ & & 11 & \\
\hline STAMPIR BR & $\mathrm{H}$ & $N$ & $\bar{Y}$ & 1 & . & 1 \\
\hline STANDAK $250 \mathrm{FS}$ & 1 & $N$ & $Y$ & II & . & IV \\
\hline STANDOUT & $\mathrm{H}$ & $\mathbf{N}$ & $Y$ & II & . & III \\
\hline STAPLE $280 \mathrm{CS}$ & $\mathrm{H}$ & $N$ & $Y$ & II & . & III \\
\hline STARANE 200 & $\mathrm{H}$ & $N$ & $Y$ & II & . & 11 \\
\hline STARICE & $\mathrm{H}$ & $N$ & $Y$ & II & . & II \\
\hline STARON SC & $\mathrm{H}$ & $Y$ & $Y$ & II & II & II \\
\hline STAUZINA 500 SC & $\mathrm{H}$ & $Y$ & $Y$ & NA & III & NA \\
\hline STAUZINA 800 PM & $\mathrm{H}$ & $Y$ & $\mathrm{Y}$ & NA & III & NA \\
\hline STIRRUP M & 0 & $Y$ & $Y$ & IV &. & \\
\hline STROBY SC & $F$ & $\mathrm{~N}$ & Y & II & . & III \\
\hline STRON & 1 & $\mathrm{~N}$ & $\mathrm{Y}$ & NA & . & 1 \\
\hline SULFICAMP & $\mathrm{F}$ & $Y$ & Y & NA & IV & NA \\
\hline SULFUR 800 & 1 & $\mathrm{~N}$ & $Y$ & IV & . & IV \\
\hline SULFURE 750 & 1 & $N$ & $Y$ & IV & & IV \\
\hline SUMICIDIN 10 UBV & 1 & $Y$ & $\mathrm{~N}$ & & II & \\
\hline SUMICIDIN 200 & 1 & $Y$ & $Y$ & NA & II & NA \\
\hline SUMICIDIN 25 UBV & 1 & $Y$ & $Y$ & NA & II & NA \\
\hline SUMIDAN $150 \mathrm{SC}$ & 1 & $\mathrm{~N}$ & Y & 11 & . & II \\
\hline SUMIDAN $25 \mathrm{CE}$ & 1 & $\mathrm{~N}$ & $Y$ & NA & & 1 \\
\hline SUMI-EIGHT PM & $F$ & $Y$ & $N$ & . & III &. \\
\hline SUMIFOG & 1 & $Y$ & $\mathrm{~N}$ & 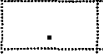 & III & \\
\hline SUMIFOG 70 & 1 & $Y$ & Y & NA & III & III \\
\hline SUMIGRAN $500 \mathrm{CE}$ & 1 & $N$ & $Y$ & NA & . & II \\
\hline SUMIGRANPLUS & 1 & $N$ & $Y$ & 1 & & II \\
\hline SUMILEX 500 PM & $\mathrm{F}$ & $\mathrm{N}$ & $\mathrm{Y}$ & II & . & II \\
\hline SUMISOYA & $\mathrm{H}$ & $\mathrm{N}$ & $\mathrm{Y}$ & III & . & IIII \\
\hline SUMITHION 400 PM & 1 & $Y$ & $Y$ & II & 11 & NA \\
\hline SUMITHION 500 CE & 1 & Y & $Y$ & NA & II & NA \\
\hline SUMITHION UBV & 1 & $\mathrm{~N}$ & $Y$ & NA & $\cdot$ & II \\
\hline SUPPORT & $\mathrm{F}$ & $Y$ & $Y$ & NA & IV & NA \\
\hline SUPRACID $400 \mathrm{CE}$ & 1 & $Y$ & $Y$ & II & 1 & II \\
\hline SUPRATHION FERSOL $400 \mathrm{CE}$ & 1 & $Y$ & $Y$ & NA & 1 & NA \\
\hline SURCOPUR & $\mathrm{H}$ & $Y$ & $\mathrm{~N}$ & . & II &. \\
\hline SURFLAN 480 & $\mathrm{H}$ & $Y$ & $\mathrm{~N}$ & 1 & III & \\
\hline SURFLAN 750 BR & $\mathrm{H}$ & $Y$ & $Y$ & NA & III & III \\
\hline
\end{tabular}


(continuação do Anexo II)

\begin{tabular}{|c|c|c|c|c|c|c|}
\hline PRODUTOS COMERCIAIS & USO & 1990 & 2000 & CPA & CT90 & CT98 \\
\hline SURPASS & $\mathrm{H}$ & $\mathrm{N}$ & $Y$ & 1 & & 1 \\
\hline SUTAN 720 CE & H & $Y$ & $\mathrm{Y}$ & NA & III & NA \\
\hline SUTAZIN $576+144$ SC & $\mathrm{H}$ & $Y$ & $Y$ & NA & 1 & NA \\
\hline SWEEPER & $\mathrm{H}$ & $\mathrm{N}$ & $Y$ & III & & III \\
\hline SWINGTOX MALATOL & 1 & $Y$ & $Y$ & NA & II & 11 \\
\hline SYSTHANE CE & $F$ & $N$ & Y & II & . & 1 \\
\hline SYSTHANE PM & $\mathrm{F}$ & $N$ & $Y$ & II & 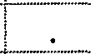 & III \\
\hline TACKLE 170 & $H$ & Y & Y & NA & 1 & 1 \\
\hline TALCORD $250 \mathrm{CE}$ & 1 & $Y$ & $Y$ & 1 & II & NA \\
\hline TALCORD 250 EC & 1 & $N$ & $Y$ & 1 & & III \\
\hline TALSTAR $100 \mathrm{CE}$ & 1 & $Y$ & $Y$ & NA & II & NA \\
\hline TAMARON BR & 1 & $Y$ & $Y$ & 11 & 1 & II \\
\hline TANGER & 1 & $Y$ & $\mathrm{~N}$ & . & III & 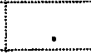 \\
\hline TARGA-50 CE & $\mathrm{H}$ & $N$ & $Y$ & II & . & 1 \\
\hline TATOO C & $F$ & $\mathbf{N}$ & $Y$ & II & . & 1 \\
\hline TEBUTHIURON SANACHEN 500 SC & $\mathrm{H}$ & $\mathrm{N}$ & Y & II & & III \\
\hline TECTO 100 & $F$ & $Y$ & Y & NA & IV & NA \\
\hline TECTO 450 & $\mathrm{~F}$ & $\mathrm{Y}$ & $\mathrm{N}$ & & III & \\
\hline TECTO 600 & $F$ & $Y$ & $Y$ & NA & IV & NA \\
\hline TECTO SC & $F$ & $N$ & Y & 11 & & III \\
\hline TEDION 80 & 1 & $Y$ & $\mathrm{~N}$ & & III & \\
\hline TEGRAN & $F$ & $\mathrm{~N}$ & $Y$ & II & . & II \\
\hline TEMIK 100 & 1 & $N$ & $Y$ & II & 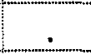 & 1 \\
\hline TEMIK 150 & 1 & $Y$ & $Y$ & II & 1 & NA \\
\hline TENTO 867 CS & $\mathrm{H}$ & $N$ & $Y$ & II & . & 1 \\
\hline TERMAZOL & $F$ & $Y$ & $N$ & . & III & . \\
\hline TERMICIDOL PO & 1 & $\mathrm{~N}$ & $Y$ &. & . & II \\
\hline TERRACLOR 750 PM & $\mathrm{F}$ & $N$ & $Y$ & 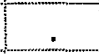 & & III \\
\hline TERRACLOR 750 PM BR UNIROYAL & $\mathrm{F}$ & $Y$ & $Y$ & NA & III & NA \\
\hline TERRACOAT UNIROYAL & $\mathrm{F}$ & $\mathrm{Y}$ & Y & NA & 11 & NA \\
\hline TERRAZOLE 350 PM & $\mathrm{F}$ & $Y$ & $Y$ & NA & III & NA \\
\hline THIAMETHOXAM & 1 & $N$ & $Y$ & . & . & 1 \\
\hline THIOBEL 500 & 1 & $Y$ & $Y$ & 11 & II & III \\
\hline THIODAN $20 \mathrm{P}$ & 1 & $Y$ & $N$ & . & III & \\
\hline THIODAN $30 \mathrm{P}$ & 1 & $Y$ & $Y$ & NA & III & III \\
\hline THIODAN $500 \mathrm{SC}$ & 1 & $Y$ & $N$ &. & 11 & \\
\hline THIODAN CE & 1 & $Y$ & $Y$ & 1 & 1 & II \\
\hline THIODAN SC & 1 & $Y$ & $N$ & & 11 & \\
\hline THIODAN UBV & 1 & $\mathrm{Y}$ & $Y$ & 1 & 1 & III \\
\hline THIONEX 350 CE & 1 & $\mathrm{~N}$ & $Y$ & 1 & . & 1 \\
\hline THIOVIT & $\mathrm{F}$ & $Y$ & $\mathrm{~N}$ & & IV & \\
\hline
\end{tabular}


(continuação do Anexo II)

\begin{tabular}{|c|c|c|c|c|c|c|}
\hline PRODUTOS COMERCIAIS & USO & 1990 & 2000 & CPA & CT9 & CT98 \\
\hline THIOVIT 800 SC & $\mathrm{F}$ & $\mathrm{Y}$ & $\mathrm{N}$ & & IV & \\
\hline THIOVIT SANDOZ & 1 & $\mathrm{~N}$ & Y & IV & 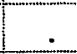 & IV \\
\hline THIRAM 480 T.S. & $F$ & $N$ & Y & 1 & & IV \\
\hline THURICIDE & 1 & $\mathrm{Y}$ & Y & IV & IV & IV \\
\hline TIFON 250 SC & 1 & $Y$ & Y & NA & III & NA \\
\hline TIGER $100 \mathrm{CE}$ & I & $\mathrm{N}$ & Y & II & & 1 \\
\hline TILT & $F$ & $Y$ & Y & II & II & III \\
\hline TIOFANATO SANACHEN 500 SC & $F$ & $N$ & Y & III & & IV \\
\hline TIOFANIL & $F$ & Y & $Y$ & NA & II & NA \\
\hline TIOMET $400 \mathrm{CE}$ & 1 & Y & Y & NA & 1 & NA \\
\hline TMB TUBO MATA BICUDO & 1 & N & Y & IV & & III \\
\hline TOKUTHION 500 CE & 1 & $\mathrm{~N}$ & $Y$ & 1 & & II \\
\hline TOPEZE & $\mathrm{H}$ & Y & Y & NA & III & III \\
\hline TOPEZE SC & $\mathrm{H}$ & Y & Y & NA & III & III \\
\hline TOPGAN & $\mathrm{H}$ & N & Y & III & & IV \\
\hline TOPGAN GRDA & $\mathrm{H}$ & $\mathrm{N}$ & $\mathrm{Y}$ & III & & III \\
\hline TORDON $10 \mathrm{GR}$ & $\mathrm{H}$ & Y & $\mathrm{N}$ & . & III & \\
\hline TORDON 2,4-D 64/240 TRIETANOLAMINA BR & $\mathrm{H}$ & Y & Y & NA & 1 & NA \\
\hline TORQUE 500 SC & 1 & Y & Y & II & III & NA \\
\hline TOTRIL & $\mathrm{H}$ & Y & $\mathrm{Y}$ & NA & 1 & 1 \\
\hline TOUCHDOWN & $H$ & $\mathrm{~N}$ & $Y$ & III & & IV \\
\hline TRACER & 1 & $\mathrm{~N}$ & Y & III & . & III \\
\hline TREBON $100 \mathrm{SC}$ & 1 & $\mathrm{~N}$ & Y & III & & IV \\
\hline TREBON $300 \mathrm{CE}$ & 1 & $\mathrm{~N}$ & Y & II & $=$ & III \\
\hline TREFLAN & $\mathrm{H}$ & Y & $\mathrm{N}$ & 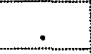 & II & \\
\hline TRIAMEX 500 SC & $\mathrm{H}$ & Y & Y & NA & III & NA \\
\hline TRIBAN & $\mathrm{H}$ & $Y$ & $\mathrm{~N}$ & . & II & \\
\hline TRICLORFON 500 DEFENSA & 1 & Y & $N$ &. & II & \\
\hline TRICLORFON 800 PS DEFENSA & 1 & Y & $N$ & . & II & \\
\hline TRICOFOL CE & 1 & $\mathrm{~N}$ & Y & 1 & & 1 \\
\hline TRIFLURALINA ATANOR 445 CE & $\mathrm{H}$ & $\mathrm{N}$ & Y & II & & II \\
\hline TRIFLURALINA DEFENSA & $\mathrm{H}$ & Y & Y & II & II & III \\
\hline TRIFLURALINA FERSOL $445 \mathrm{CE}$ & $\mathrm{H}$ & $\mathrm{N}$ & $\mathrm{Y}$ & II & & II \\
\hline TRIFLURALINA GR NORTOX & $\mathrm{H}$ & Y & $\mathrm{Y}$ & NA & III & NA \\
\hline TRIFLURALINA HOECHST & $\mathrm{H}$ & Y & $Y$ & II & 11 & 11 \\
\hline TRIFLURALINA MILENIA & $\mathrm{H}$ & $\mathrm{N}$ & $Y$ & II & . & III \\
\hline TRIFLURALINA NORTOX & $\mathrm{H}$ & Y & Y & II & II & II \\
\hline TRIFLURALINA NORTOX GOLD & $\mathrm{H}$ & $\mathrm{N}$ & Y & II & & $\|$ \\
\hline TRIFLURALINA SANACHEN 445 CE & $\mathrm{H}$ & $\mathrm{N}$ & $Y$ & . & & II \\
\hline TRIFMINE. & $F$ & $\mathrm{~N}$ & Y & III & & IV \\
\hline TRIGARD 750 PM & 1 & Y & $N$ & III & III & IV \\
\hline
\end{tabular}


(continuação do Anexo II)

\begin{tabular}{|c|c|c|c|c|c|c|}
\hline PRODUTOS COMERCIAIS & USO & 1990 & 2000 & CPA & СТ9C & СТ98 \\
\hline TRIONA & 1 & $Y$ & $Y$ & III & IV & IV \\
\hline TRI-SCEPT & $\mathrm{H}$ & $\mathrm{N}$ & Y & 1 & & II \\
\hline TRITAC & $\mathrm{H}$ & $\mathrm{Y}$ & $\mathrm{Y}$ & NA & III & NA \\
\hline TROP & $\mathrm{H}$ & $\mathrm{N}$ & $\mathrm{Y}$ & III & & IV \\
\hline TROPAZIN & $\mathrm{H}$ & $Y$ & $Y$ & NA & II & II \\
\hline TROPURON & $\mathrm{H}$ & $\mathrm{N}$ & $\mathrm{Y}$ & NA & . & III \\
\hline TRUCO $108 \mathrm{CE}$ & $\mathrm{H}$ & $\mathrm{N}$ & $Y$ & III & . & 1 \\
\hline TRUCO 18 & $\mathrm{H}$ & $\mathrm{N}$ & $Y$ & III & . & 1 \\
\hline TUFORDON & $\mathrm{H}$ & Y & $N$ & & 1 & \\
\hline TURBO & 1 & $\mathrm{~N}$ & $Y$ & II &. & II \\
\hline TUVAL & 0 & $\mathrm{~N}$ & $\mathrm{Y}$ & IIII & . & IV \\
\hline U 46 COMBI FLUID 550 & $\mathrm{H}$ & $Y$ & $Y$ & NA & II & NA \\
\hline U 46 D FLUID 2,4-D & $\mathrm{H}$ & $\mathrm{Y}$ & Y & NA & 1 & NA \\
\hline U 46 D-ESTER & $\mathrm{H}$ & $Y$ & $\mathrm{Y}$ & NA & II & NA \\
\hline U 46 M FLUID 625 MCPA & $\mathrm{H}$ & $\mathrm{Y}$ & $N$ & . & 11 & \\
\hline UNDEN PO & 1 & $Y$ & $\mathrm{~N}$ & 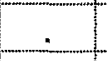 & III & \\
\hline VALIENT & 1 & N & Y & III & (a) & IV \\
\hline VALON 384 CE & 1 & $Y$ & $Y$ & NA & 11 & NA \\
\hline VANOX $500 \mathrm{SC}$ & $F$ & $Y$ & $Y$ & NA & 1 & NA \\
\hline VANOX 750 PM & $F$ & $Y$ & Y & NA & II & NA \\
\hline VEGET'OIL & 1 & N & $Y$ & IV & . & IV \\
\hline VELPAR K & $\mathrm{H}$ & $Y$ & $Y$ & NA & II & NA \\
\hline VELPAR K-GRDA & $H$ & $Y$ & $\mathrm{~N}$ & 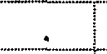 & III & $=$ \\
\hline VENTUROL & $\mathrm{F}$ & $Y$ & $Y$ & NA & II & NA \\
\hline VERDICT & $\mathrm{H}$ & $Y$ & $\mathrm{~N}$ & & 1 & \\
\hline VERDICT-R & $\mathrm{H}$ & $\mathrm{N}$ & Y & III &. & II \\
\hline VERNAM 720 CE & $\mathrm{H}$ & $Y$ & $N$ & 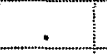 & II & \\
\hline VERTIMEC $18 \mathrm{CE}$ & 1 & $Y$ & $Y$ & II & 1 & III \\
\hline VETRAN & $F$ & Y & $\mathrm{N}$ &. & III & 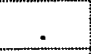 \\
\hline VEXTER & 1 & $\mathrm{~N}$ & $Y$ & II &. & II \\
\hline VEZIR & $\mathrm{H}$ & $\mathrm{N}$ & $Y$ & III & . & IV \\
\hline VEZIR GRDA & $\mathrm{H}$ & $\mathrm{N}$ & $Y$ & III &. & III \\
\hline VINCIT 2,5 DS & $F$ & $N$ & $Y$ & III & 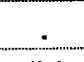 & IV \\
\hline VIRICOBRE PM & $F$ & $Y$ & $Y$ & NA & IV & NA \\
\hline VISOR $240 \mathrm{CE}$ & $\mathrm{H}$ & $\mathrm{N}$ & $Y$ & II &. & 11 \\
\hline VITAVAX - THIRAM PM UNIROYAL & $F$ & $Y$ & $\mathrm{~N}$ & 1 & II & . \\
\hline VITAVAX 750 PM BR & $F$ & Y & $N$ & & 11 & \\
\hline VITAVAX-THIRAN 200 SC & $F$ & $N$ & $Y$ & 1 & . & IV \\
\hline VITIGRAN AZUL BR & $F$ & $Y$ & $Y$ & NA & & NA \\
\hline VITIGRAN VERDE BR & $F$ & Y & $Y$ & NA & & NA \\
\hline VOLCANE & $H$ & $\mathrm{~N}$ & Y & III & . & III \\
\hline
\end{tabular}


(final do Anexo II)

\begin{tabular}{|c|c|c|c|c|c|c|}
\hline PRODUTOS COMERCIAIS & USO & 1990 & 2000 & CPA & CT90 & CT98 \\
\hline VOLT & $\mathrm{H}$ & $\mathbf{N}$ & $Y$ & 11 & . & 1 \\
\hline WHIP S & $\mathrm{H}$ & $\mathbf{N}$ & $Y$ & 11 & . & II \\
\hline WHITEREX & 0 & $N$ & $Y$ & IV & . & IV \\
\hline WIL FIX & 0 & $N$ & $Y$ & NA &. & IV \\
\hline WINNER & 1 & $\mathrm{~N}$ & $Y$ & III &. & III \\
\hline XENTARI & 1 & $N$ & $Y$ & IV & . & II \\
\hline ZAPP & $\mathrm{H}$ & $N$ & $Y$ & III & 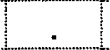 & IV \\
\hline ZETA 900 & $\mathrm{H}$ & $N$ & $Y$ & II &. & 1 \\
\hline ZOLONE $350 \mathrm{CE}$ & 1 & $Y$ & $N$ & . & II & . \\
\hline ZOLONE UBV & I & $Y$ & $N$ & . & 11 & . \\
\hline
\end{tabular}




\section{ANEXO 3 - banco de dados no 4 - Classificação Toxicológica}

A Classe Toxicológica dos produtos comerciais foi determinada de acordo com o descrito na metodologia referente ao objetivo específico $\mathrm{n}^{\circ} 2$.

\section{LEGENDA:}

- CT80E (Classe Toxicológica referente à Portaria DISAD nº 4/80): I - altamente tóxico ; II - medianamente tóxico ; III - pouco tóxico ; IV - praticamente não tóxico;

- CT92E (Classe Toxicológica referente à Portaria SNVS no 3/92): I - extremamente tóxico ; II - altamente tóxico ; III - medianamente tóxico ; IV - pouco tóxico;

\begin{tabular}{|l|c|c|}
\hline PRODUTOS COMERCIAIS & CT80E & CT92E \\
\hline 2,4-D FERSOL & & \\
\hline ACARDIFON & II & III \\
\hline ACARISTOP 500 SC & IV & IV \\
\hline ACEFATO FERSOL 50P & IV & IV \\
\hline ACEFATO FERSOL 750 PS & III & IV \\
\hline ACTELLIC 500 CE & III & IV \\
\hline ADDIX & $\cdot$ & $\cdot$ \\
\hline ADESIN BR & $\cdot$ & $\cdot$ \\
\hline ADITIV & $\cdot$ & $\cdot$ \\
\hline AFALON 500 BR & IV & IV \\
\hline AFALON SC & IV & IV \\
\hline AFUGAN CE & $\cdot$ & III \\
\hline AG-BEM & III & IV \\
\hline AGIMIX & $\cdot$ & $\cdot$ \\
\hline AGRAL & $\cdot$ & $\cdot$ \\
\hline AGREX & $\cdot$ & $\cdot$ \\
\hline AGRIMICINA & II & III \\
\hline AGRITRIN SC & $\cdot$ & $\cdot$ \\
\hline AGROTENSIL & &. \\
\hline
\end{tabular}


(continuação do Anexo III)

\begin{tabular}{|c|c|c|}
\hline PRODUTOS COMERCIAIS & CT80E & CT92E \\
\hline \multicolumn{3}{|l|}{ ALIETTE } \\
\hline ALLISAN BR & IV & IV \\
\hline \multicolumn{3}{|l|}{ ALTERNE } \\
\hline AMBUSH $500 \mathrm{CE}$ & II & III \\
\hline AMETRON SC & III & IV \\
\hline \multicolumn{3}{|l|}{ AMEX } \\
\hline AMINOL & II & III \\
\hline \multicolumn{3}{|l|}{ ANTAK BR } \\
\hline ANTHIO & II & III \\
\hline ANTICAR & II & III \\
\hline APRON & III & IV \\
\hline \multicolumn{3}{|l|}{ AQUAMIX } \\
\hline ARRIVO $200 \mathrm{CE}$ & $\|$ & III \\
\hline ARROZAN & II & III \\
\hline ARSENAL 250 & IV & IV \\
\hline \multicolumn{3}{|l|}{ ASSIST } \\
\hline ASULOX 400 & IV & IV \\
\hline \multicolumn{3}{|l|}{ ATERBANE BR } \\
\hline ATRAZINAX 500 & III & IV \\
\hline AURAM 700 & III & IV \\
\hline AZODRIN 400 & 1 & II \\
\hline AZODRIN 75 UBV & 1 & II \\
\hline BANIR & III & IV \\
\hline BANVEL 480 & III & IV \\
\hline BASAGRAN 480 & III & IV \\
\hline BASUDIN 140 GR & IV & IV \\
\hline BASUDIN 25 P & IV & IV \\
\hline BAYCOR & IV & IV \\
\hline BAYFIDAN CE & III & IV \\
\hline BAYLETON BR & IV & IV \\
\hline BAYSISTON GR & 1 & II \\
\hline BAYTAN 150 & IV & IV \\
\hline BAYTAN 250 & IV & IV \\
\hline BAYTAN SC & III & IV \\
\hline BAYTROID CE & III & IV \\
\hline BELMARK 25 UBV & IV & IV \\
\hline BELMARK 75 CE & III & IV \\
\hline BENDAZOL & IV & IV \\
\hline BENLATE 500 & IV & IV \\
\hline BI-HEDONAL & II & III \\
\hline $\mathrm{BIM} 500 \mathrm{SC}$ & II & III \\
\hline
\end{tabular}


(continuação do Anexo III)

\begin{tabular}{|c|c|c|}
\hline PRODUTOS COMERCIAIS & CT80E & СT92E \\
\hline BIM $750 \mathrm{BR}$ & II & III \\
\hline \multicolumn{3}{|l|}{ BIMATE PM } \\
\hline BIRLANE $250 \mathrm{P}$ & II & III \\
\hline BLADAL 700 & II & III \\
\hline BLADAL SC & 11 & III \\
\hline BLADEX 500 & II & III \\
\hline \multicolumn{3}{|l|}{ BLAZER SOL } \\
\hline BLAZINA SC & II & III \\
\hline \multicolumn{3}{|l|}{ BORDAMIL } \\
\hline BOXER & III & IV \\
\hline BRAVONIL 500 SDS & IV & IV \\
\hline BRAVONIL $750 \mathrm{PM}$ & IV & IV \\
\hline BREMAZIN & IV & IV \\
\hline BRESTAN PM & III & IV \\
\hline \multicolumn{3}{|l|}{ BROMEX } \\
\hline \multicolumn{3}{|l|}{ BROMO FLORA } \\
\hline \multicolumn{3}{|l|}{ BROMO-FERSOL } \\
\hline \multicolumn{3}{|l|}{ CAPTAN 250 MOLY } \\
\hline CAPTAN 480 SC DEFENSA & IV & IV \\
\hline CAPTAN 500 PM & IV & IV \\
\hline CAPTAN 750 TS & IV & IV \\
\hline CAPTAN FERSOL 500 PM & IV & IV \\
\hline CAPTAN SC & IV & IV \\
\hline CARBALATE $480 \mathrm{SC}$ & II & III \\
\hline CARBARIL 480 SC DEFENSA & II & III \\
\hline CARBARYL FERSOL $480 \mathrm{SC}$ & II & III \\
\hline CARBARYL FERSOL $50 \mathrm{P}$ & IV & IV \\
\hline CARBARYL FERSOL 850 PM & 11 & III \\
\hline CARBARYL FERSOL PO 75 & IV & IV \\
\hline CARBAX & IIII & IV \\
\hline CARBION $75 \mathrm{P}$ & IV & IV \\
\hline CARBORAN FERSOL 350 SC & 1 & II \\
\hline CARBORAN FERSOL $50 \mathrm{G}$ & II & III \\
\hline \multicolumn{3}{|l|}{ CARTAP BR 500} \\
\hline CARVIN 850 PM & II & III \\
\hline CASORON 67,5 GR & IV & IV \\
\hline CEFANOL & III & IV \\
\hline CENTION 800 & IV & IV \\
\hline CENTION SC & IV & IV \\
\hline CERCOBIN 500 SC & IV & IV \\
\hline CERCOBIN $700 \mathrm{PM}$ & IV & IV \\
\hline
\end{tabular}


(continuação do Anexo III)

\begin{tabular}{|c|c|c|}
\hline PRODUTOS COMERCIAIS & CT80E & CT92E \\
\hline CERCONIL PM & IV & IV \\
\hline CERCONIL SC & IV & IV \\
\hline $\mathrm{CICOL}$ & III & IV \\
\hline \multicolumn{3}{|l|}{ CITOWETT 200} \\
\hline \multicolumn{3}{|l|}{ CLASSIC } \\
\hline CLOROBENZILATO 500 CE FERSOL & II & III \\
\hline CLORPIRIFOS 480 CE DEFENSA & II & III \\
\hline COACT $360 \mathrm{CE}$ & IV & IV \\
\hline \multicolumn{3}{|l|}{ COBRA } \\
\hline COBRE FERSOL & III & IV \\
\hline COBRE SANDOZ BR & III & IV \\
\hline COBRE SANDOZ P & IV & IV \\
\hline COBRE SANDOZ SC & 11 & III \\
\hline COMBILAN PM & IV & IV \\
\hline COMBINE $500 \mathrm{SC}$ & II & III \\
\hline COMMAND & III & IV \\
\hline COMMENCE 630 CE & III & IV \\
\hline COPIDROL PM & III & IV \\
\hline COPIDROL SC & III & IV \\
\hline COPRANTOL BR & III & IV \\
\hline CORSUM & III & IV \\
\hline CUPRAVIT AZUL 500 & III & IV \\
\hline CUPRAVIT AZUL BR & IV & IV \\
\hline CUPRAVIT VERDE & III & IV \\
\hline CUPRODIL & IV & IV \\
\hline CUPROSAN AZUL PM & IV & IV \\
\hline CUPROZEB & IV & IV \\
\hline CURACRON 500 & II & III \\
\hline CURZATE M + ZINCO & IV & IV \\
\hline CYCOCEL $100 \mathrm{~A}$ & IV & IV \\
\hline CYCOCEL $500 \mathrm{~A}$ & II & III \\
\hline CYMBUSH $250 \mathrm{CE}$ & II & III \\
\hline CYMBUSH 30 ED BICO BRANCO & IV & IV \\
\hline CYMBUSH 40 ED BICO AMARELO & IV & IV \\
\hline CYTHION 1000 & III & IV \\
\hline CYTHION UBV & II & III \\
\hline DACOBRE PM & IV & IV \\
\hline DACONIL BR & IV & IV \\
\hline DACOSTAR 500 & IV & IV \\
\hline DACOSTAR 750 & IV & IV \\
\hline DANIMEN $300 \mathrm{CE}$ & II & III \\
\hline
\end{tabular}


(continuação do Anexo III)

\begin{tabular}{|c|c|c|}
\hline PRODUTOS COMERCIAIS & CT80E & CT92E \\
\hline DDVP 1000 CE DEFENSA & 1 & 11 \\
\hline DDVP 500 CE CALAIS & 1 & II \\
\hline DDVP 500 CE DEFENSA & 1 & II \\
\hline DECIS 25 CE & III & IV \\
\hline DECIS 4 UBV & IV & IV \\
\hline DECIS 50 SC & III & IV \\
\hline DECIS FOG FORMICIDA & III & IV \\
\hline DECIS FORMICIDA $4 \mathrm{P}$ & IV & IV \\
\hline DECISDAN CE & II & III \\
\hline DEFERON & II & III \\
\hline DELAN & III & IV \\
\hline DESSECAN & III & IV \\
\hline DEVRINOL 500 PM & IV & IV \\
\hline DIAFURAN 50 & II & III \\
\hline DIAZINON 400 PM CIBA-GEIGY & III & IV \\
\hline DIAZINON 600 CE & II & III \\
\hline DICAROL CE & III & IV \\
\hline DICOFOL FERSOL 185 CE & III & IV \\
\hline DICOFOL HERBITECNICA CE & III & IV \\
\hline DIK $185 \mathrm{CE}$ & III & IV \\
\hline DIMECRON 500 & 1 & 1 \\
\hline DIMETHOATO FERSOL $400 \mathrm{CE}$ & 11 & III \\
\hline DIMETOATO 200 GR NORTOX & III & IV \\
\hline DIMETOATO 500 CE NORTOX & II & III \\
\hline DIMETOATO CE & II & III \\
\hline DIMEXION & II & III \\
\hline DIMILIN & IV & IV \\
\hline \multicolumn{3}{|l|}{ DIPEL PM } \\
\hline DIPTEREX 500 & 11 & III \\
\hline DIPTEREX PO 25 & IV & IV \\
\hline DIRECT & IV & IV \\
\hline \multicolumn{3}{|l|}{ DISSECA 200} \\
\hline DISSULFAN CE & II & III \\
\hline DISSULFAN UBV & II & III \\
\hline DISYSTON GR 100 & 1 & II \\
\hline DISYSTON GR 50 & 1 & III \\
\hline DITHANE PM & IV & IV \\
\hline DITHANE SC & IV & IV \\
\hline DITHIOBIN 780 PM & IV & IV \\
\hline DIURON 480 + AMETRINA 310 NORTOX & IV & IV \\
\hline DIURON 500 SC DEFENSA & IV & IV \\
\hline
\end{tabular}


(continuação do Anexo III)

\begin{tabular}{|c|c|c|}
\hline PRODUTOS COMERCIAIS & CT80E & CT92E \\
\hline DIURON FERSOL 500 SC & IV & IV \\
\hline DIURON FERSOL 800 PM & IV & IV \\
\hline DIURON NORTOX & IV & IV \\
\hline DIURON PM HOECHST & IV & IV \\
\hline DIURON SC HOECHST & IV & IV \\
\hline DMA 480 BR & II & III \\
\hline DMA 806 BR & II & III \\
\hline DODEX 450 SC & III & IV \\
\hline DONTOR & II & III \\
\hline \multicolumn{3}{|l|}{ DU FOL } \\
\hline DUAL 720 CE & III & IV \\
\hline DUAL $960 \mathrm{CE}$ & III & IV \\
\hline DYRENE 480 & III & IV \\
\hline EKATIN & II & III \\
\hline ELOSAL SC & III & IV \\
\hline ENDOSULFAN 350 CE DEFENSA & 11 & IIII \\
\hline ENDOSULFAN FERSOL 350 CE & 11 & III \\
\hline ENDOZOL & 1 & II \\
\hline \multicolumn{3}{|l|}{ ENERGIC } \\
\hline EPTAM 720 CE & III & IV \\
\hline \multicolumn{3}{|l|}{ ERADICANE } \\
\hline ERBAN 360 & III & IV \\
\hline ERBAN 480 & III & IV \\
\hline \multicolumn{3}{|l|}{ ESPALHANTE ADESIVO BAYER } \\
\hline \multicolumn{3}{|l|}{ ESPALHANTE ADESIVO FERSOL } \\
\hline \multicolumn{3}{|l|}{ ESPALHANTE ADESIVO FERTIBRAS } \\
\hline ETHION 500 RHODIA AGRO & 11 & III \\
\hline ETHREL & IV & IV \\
\hline ETHREL 2,5 PT & IV & IV \\
\hline ETHRELPT & IV & IV \\
\hline \multicolumn{3}{|l|}{ EXTRAVON } \\
\hline FACET PM & IV & IV \\
\hline FACTOR & IV & IV \\
\hline FENIX & 11 & III \\
\hline FENVALERATE 200 CE DEFENSA & III & IV \\
\hline \multicolumn{3}{|l|}{ FERMAG } \\
\hline FERRAX 400 ED BICO AMARELO & IV & IV \\
\hline \multicolumn{3}{|l|}{ FERTOXIN BR } \\
\hline \multicolumn{3}{|l|}{ FIXADE } \\
\hline FLEX & III & IV \\
\hline FLOUCOBRE FERSOL & III & IV \\
\hline
\end{tabular}


(continuação do Anexo III)

\begin{tabular}{|c|c|c|}
\hline PRODUTOS COMERCIAIS & CT80E & CT92E \\
\hline FLOUGURAN & III & IV \\
\hline FOLICUR CE & IV & IV \\
\hline FOLIDOL 600 & 1 & II \\
\hline FOLIMAT 1000 & 1 & II \\
\hline FOLPET 500 PM & IV & IV \\
\hline FONGORENE & III & IV \\
\hline \multicolumn{3}{|l|}{ FORMICIDA DEFENSA GR 45} \\
\hline \multicolumn{3}{|l|}{ FORMICIDA GRANULADO LANDRIN } \\
\hline FORMILIN & IV & IV \\
\hline \multicolumn{3}{|l|}{ FORMIREX } \\
\hline FORMULA 480 BR & II & III \\
\hline FORTEX SC & III & IV \\
\hline FOSFERNO 500 ED BICO AMARELO & III & IV \\
\hline \multicolumn{3}{|l|}{ FRIGATE } \\
\hline \multicolumn{3}{|l|}{ FRONT PM } \\
\hline \multicolumn{3}{|l|}{ FRUITONE } \\
\hline FRUMIN & 1 & 1 \\
\hline FUNGINEB 800 & IV & IV \\
\hline FUNGINIL & IV & IV \\
\hline FUNGISCAN 500 SC & IV & IV \\
\hline FUNGISCAN 700 PM & IV & IV \\
\hline FUNGITOX $500 \mathrm{SC}$ & II & III \\
\hline FURADAN 350 SC & 1 & II \\
\hline FURADAN 350 TS & 1 & II \\
\hline FURADAN $50 \mathrm{G}$ & II & III \\
\hline FURAZIN 310 TS & 1 & 11 \\
\hline FURORE & IV & IV \\
\hline FUSIFLEX & IV & IV \\
\hline FUSILADE 125 & IV & IV \\
\hline \multicolumn{3}{|l|}{ GALLANT 240 BR } \\
\hline GAMIT & III & IV \\
\hline GARLON 480 BR & II & III \\
\hline \multicolumn{3}{|l|}{ GASTOXIN } \\
\hline \multicolumn{3}{|l|}{ GASTOXIN PASTA } \\
\hline GESAGARD 800 CIBA-GEIGY & IV & IV \\
\hline GESAPAX 500 CIBA-GEIGY & III & IV \\
\hline GESAPAX 800 PM CIBA-GEIGY & III & IV \\
\hline GESAPRIM 500 CIBA-GEIGY & III & IV \\
\hline GESAPRIM 800 PM & IV & IV \\
\hline GESATOP 500 & IV & IV \\
\hline GESATOP 800 PM & IV & IV \\
\hline
\end{tabular}


(continuação do Anexo III)

\begin{tabular}{|c|c|c|}
\hline PRODUTOS COMERCIAIS & СT80E & CT92E \\
\hline GESAVEROL 40 & IV & IV \\
\hline GLIFOSATO FERSOL & IV & IV \\
\hline GLIFOSATO NORTOX & IV & IV \\
\hline GOAL BR & IV & IV \\
\hline \multicolumn{3}{|l|}{ GOTAFIX } \\
\hline \multicolumn{3}{|l|}{ GRAMOCIL } \\
\hline \multicolumn{3}{|l|}{ GRAMOXONE 200} \\
\hline GRANUTOX & 1 & II \\
\hline GRASLAN 100 PELETIZADO & IV & IV \\
\hline GRASLAN 200 PELETIZADO & IV & IV \\
\hline GRASLAN 400 PELETIZADO & III & IV \\
\hline GRASSAID & III & IV \\
\hline GUSATHION 400 & 1 & II \\
\hline HERBADOX $500 \mathrm{CE}$ & III & IV \\
\hline HERBAMINA BR & II & III \\
\hline HERBI D-480 & II & III \\
\hline HERBIFLAN & IV & IV \\
\hline HERBIMIX SC & III & IV \\
\hline HERBIPAK 500 BR & III & IV \\
\hline \multicolumn{3}{|l|}{ HERBITENSIL } \\
\hline HERBURON 500 BR & IV & IV \\
\hline HINOSAN 500 & II & IIII \\
\hline HOKKO CYHEXATIN 500 & III & IV \\
\hline \multicolumn{3}{|l|}{ HOKKO KASUMIN } \\
\hline HOKKO PLANTVAX 750 & IV & IV \\
\hline HOKKO SUZU 200 & III & IV \\
\hline HOSTATHION $400 \mathrm{BR}$ & II & III \\
\hline HYVAR 800 & IV & IV \\
\hline IHARA DIMETHOATE 500 & II & III \\
\hline \multicolumn{3}{|l|}{ IHARAGUEN-S } \\
\hline \multicolumn{3}{|l|}{ IHAROL } \\
\hline \multicolumn{3}{|l|}{ ILOXAN CE } \\
\hline IMIDAN 500 PM & II & III \\
\hline ISATALONIL & IV & IV \\
\hline ISATALONIL 500 SC & IV & IV \\
\hline \multicolumn{3}{|l|}{ ISCA 7 BELO } \\
\hline \multicolumn{3}{|l|}{ ISCA FERMEX } \\
\hline \multicolumn{3}{|l|}{ ISCA FORMICIDA AGROCERES } \\
\hline \multicolumn{3}{|l|}{ ISCA FORMICIDA ATTA-MEX } \\
\hline \multicolumn{3}{|l|}{ ISCA FORMICIDA MIRIM } \\
\hline ISCA MIRENEX & 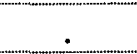 & . \\
\hline
\end{tabular}


(continuação do Anexo III)

\begin{tabular}{|c|c|c|}
\hline PRODUTOS COMERCIAIS & CT80E & CT92E \\
\hline \multicolumn{3}{|l|}{ ISCA TAMANDUA BANDEIRA } \\
\hline \multicolumn{3}{|l|}{ JOINT } \\
\hline KABAT & IV & IV \\
\hline KAETAN & III & IV \\
\hline KARATE 15 ED BICO AMARELO & III & IV \\
\hline KARATE $50 \mathrm{CE}$ & II & III \\
\hline KARMEX & IV & IV \\
\hline KARMEX $500 \mathrm{SC}$ & IV & IV \\
\hline KARMEX 800 & IV & IV \\
\hline KELTHANE 480 & II & III \\
\hline KELTHANE CE & III & IV \\
\hline KILVAL 300 & II & III \\
\hline KITAZIN 480 CE & II & III \\
\hline KITAZIN GRANULAR & IV & IV \\
\hline K-OBIOL $2 \mathrm{P}$ & IV & IV \\
\hline K-OBIOL 25 CE & III & IV \\
\hline KOBUTOL 750 & IV & IV \\
\hline KOLOSSUS & IV & IV \\
\hline KONTROLE & III & IV \\
\hline KROVAR & IV & IV \\
\hline KROVAR BR & IV & IV \\
\hline KUMULUSS & IV & IV \\
\hline$\angle A C O C E$ & II & III \\
\hline LANCE & III & IV \\
\hline \multicolumn{3}{|l|}{ LANDRIN PO } \\
\hline LANNATE BR & 1 & III \\
\hline LARVIN 350 RA & 1 & II \\
\hline LASER $350 \mathrm{CE}$ & II & III \\
\hline LEBAYCID 500 & II & III \\
\hline LEBAYCID PO & IV & IV \\
\hline LEPIDIN 600 & II & IIII \\
\hline LESMIX & IV & IV \\
\hline LEXONE SC & III & IV \\
\hline LIFALIN BR & IV & IV \\
\hline \multicolumn{3}{|l|}{ LORSBAN 240 UBV } \\
\hline \multicolumn{3}{|l|}{ LORSBAN 480 BR } \\
\hline MACHETE CE & III & IV \\
\hline MALAFOG & IV & IV \\
\hline MALAGRAN & IV & IV \\
\hline MALATHION 500 CE SULTOX & III & IV \\
\hline MALATOL $1000 \mathrm{CE}$ & III & IV \\
\hline
\end{tabular}


(continuação do Anexo III)

\begin{tabular}{|c|c|c|}
\hline PRODUTOS COMERCIAIS & CT80E & CT92E \\
\hline MALATOL $20 \mathrm{P}$ & IV & IV \\
\hline MALATOL 250 & IV & IV \\
\hline MALATOL 250 PM & IV & IV \\
\hline MALATOL $40 \mathrm{P}$ & IV & IV \\
\hline MALATOL $500 \mathrm{CE}$ & III & IV \\
\hline MALATOL UBV & 11 & III \\
\hline MANZATE BR & IV & IV \\
\hline MARCAP CE & IV & IV \\
\hline MARSHAL $250 \mathrm{CE}$ & II & III \\
\hline MARSHAL 250 TS & III & IV \\
\hline MARSHAL 350 TS & III & IV \\
\hline MARSHAL $50 \mathrm{G}$ & IV & IV \\
\hline MAVRIK & III & IV \\
\hline MAVRIK AQUAFLOW & III & IV \\
\hline MAYRAN & III & IV \\
\hline MELPREX 650 PM & III & IV \\
\hline MERTIN 400 & II & III \\
\hline METAMIDOFOS 600 DEFENSA & 1 & II \\
\hline METASYSTOX (1) CE 250 & 1 & II \\
\hline METHIL PARATHION 600 CE INSETICIDA AGROCERES & 1 & 11 \\
\hline METILTIOFAN & IV & IV \\
\hline MICROSULFAN 800 PM & IV & IV \\
\hline MICROTHIOL $750 \mathrm{SC}$ & III & IV \\
\hline MICROZOL & III & IV \\
\hline MILDEX BR &. &. \\
\hline \multicolumn{3}{|l|}{ MIREX } \\
\hline MORESTAN 500 SC & III & IV \\
\hline MORESTAN BR & IV & IV \\
\hline \multicolumn{3}{|l|}{ MYCOSHIELD } \\
\hline \multicolumn{3}{|l|}{ N-DEC } \\
\hline NEMACUR & II & III \\
\hline NEMACUR CE & 1 & II \\
\hline NEORON $500 \mathrm{CE}$ & IV & IV \\
\hline NOR-TRIN $250 \mathrm{CE}$ & II & III \\
\hline NURELLE $250 \mathrm{CE}$ & II & III \\
\hline NUVACRON 250 UBV BR & 1 & $\underline{11}$ \\
\hline NUVACRON 400 & 1 & II \\
\hline NUVAN $1000 \mathrm{CE}$ & 1 & II \\
\hline \multicolumn{3}{|l|}{ OLEO MINERAL FERSOL } \\
\hline OMITE 300 PM BR & IV & IV \\
\hline OMITE 720 CE BR & III & IV \\
\hline
\end{tabular}


(continuação do Anexo III)

\begin{tabular}{|c|c|c|}
\hline PRODUTOS COMERCIAIS & CT $80 E$ & CT92E \\
\hline ORDRAM $200 \mathrm{GR}$ & IV & IV \\
\hline ORDRAM $720 \mathrm{CE}$ & II & III \\
\hline ORDRAM GR & IV & IV \\
\hline ORTHENE $750 \mathrm{BR}$ & III & IV \\
\hline ORTHENE 750 BR PARA SEMENTES & III & IV \\
\hline ORTHO HAMIDOP 600 & 1 & II \\
\hline ORTHO NALED 860 & II & III \\
\hline ORTHOCIDE 500 & IV & IV \\
\hline PARTNER & III & IV \\
\hline PAX-HCE & II & IIII \\
\hline PAXPLUS & III & IV \\
\hline PAXPRIM PM & III & IV \\
\hline PECENOL PM & IV & IV \\
\hline PENDINIL & III & IV \\
\hline PEPROSAN & IV & IV \\
\hline PERFEKTHION & II & III \\
\hline PERFORM $360 \mathrm{CE}$ & III & IV \\
\hline PERMETRINA FERSOL $384 \mathrm{CE}$ & II & III \\
\hline PHOSDRIN $185 \mathrm{CE}$ & 1 & II \\
\hline PIREDAN & 11 & III \\
\hline PI-RIMOR 500 PM & II & III \\
\hline PLANTACOL & IV & IV \\
\hline PLANTVAX 750 PM BR & IV & IV \\
\hline POAST BASF & IV & IV \\
\hline \multicolumn{3}{|l|}{ PODIUM } \\
\hline POLYDIAL CE & 11 & III \\
\hline POLYDIAL UBV & IV & IV \\
\hline POLYTRIN 400/40 CE & II & III \\
\hline \multicolumn{3}{|l|}{ POSMAT } \\
\hline POSSE 200 ED BICO BRANCO & II & III \\
\hline POUNCE 384 CE & II & III \\
\hline \multicolumn{3}{|l|}{ PRAMATO } \\
\hline \multicolumn{3}{|l|}{ PREGLONE } \\
\hline PREMERLIN $600 \mathrm{CE}$ & IV & IV \\
\hline \multicolumn{3}{|l|}{ PREVICUR N } \\
\hline PRIMAIZ & III & IV \\
\hline PRIMATOL & IV & IV \\
\hline PRIMATOP & IV & IV \\
\hline PRIMATOP SC & III & IV \\
\hline PRIME PLUS & IV & IV \\
\hline PRIMESTRA SC & III & IV \\
\hline
\end{tabular}


(continuação do Anexo III)

\begin{tabular}{|c|c|c|}
\hline PRODUTOS COMERCIAIS & CT80E & CT92E \\
\hline PRIMOLEO & III & IV \\
\hline PROMET & 1 & II \\
\hline PROPANIL DEFENSA & III & IV \\
\hline PROPANIL FERSOL $360 \mathrm{CE}$ & III & IV \\
\hline PROPANIL ICI $360 \mathrm{CE}$ & III & IV \\
\hline PROPANIN 450 & III & IV \\
\hline PROPANIN CNDA & IIII & IV \\
\hline PROPARGITE FERSOL $720 \mathrm{CE}$ & III & IV \\
\hline RALZER 350 SC & 1 & II \\
\hline RALZER 50 GR & II & III \\
\hline RAMEXANE 850 PM & III & IV \\
\hline RAPID & IV & IV \\
\hline RAXIL 25 & IV & IV \\
\hline RECONIL & IV & IV \\
\hline RECOP & IIII & IV \\
\hline RECOP SC & III & IV \\
\hline REGLONE & 11 & III \\
\hline RHODIAURAM 700 & III & IV \\
\hline RIDOMIL - MANCOZEB BR & IV & IV \\
\hline RIDOMIL 250 PM & IV & IV \\
\hline RIDOXYL PM & III & IV \\
\hline RODEO & IV & IV \\
\hline RODISAN SC & III & IV \\
\hline RONILAN 500 & IV & IV \\
\hline RONSTAR $250 \mathrm{BR}$ & IV & IV \\
\hline RONSTAR SC & IV & IV \\
\hline ROUNDUP & IV & IV \\
\hline ROVRAL & IV & IV \\
\hline ROVRAL SC & IV & IV \\
\hline ROVRIN & III & IV \\
\hline ROYAL MH-30 BR & IV & IV \\
\hline \multicolumn{3}{|l|}{ ROYALTAC BR } \\
\hline RUBIGAN $120 \mathrm{CE}$ & IV & IV \\
\hline SANAGRAN & IV & IV \\
\hline \multicolumn{3}{|l|}{ SANDOVIT } \\
\hline SAPROL & IV & IV \\
\hline SATANIL CE & III & IV \\
\hline SATURN GR 100 & IV & IV \\
\hline SAVEY PM & IV & IV \\
\hline SCEPTER & IV & IV \\
\hline SECAFIX 850 & IV & IV \\
\hline
\end{tabular}


(continuação do Anexo III)

\begin{tabular}{|c|c|c|}
\hline PRODUTOS COMERCIAIS & CT80E & CT92E \\
\hline \multicolumn{3}{|l|}{ SECAMATO } \\
\hline SEMEVIN 350 RA & 1 & II \\
\hline SENCOR 480 & III & IV \\
\hline SENCOR BR & IV & IV \\
\hline SEVIN 480 SC & II & III \\
\hline SEVIN 50 & IV & IV \\
\hline SEVIN 75 & IV & IV \\
\hline SEVIN 850 PM & II & III \\
\hline SHELLVIN 500 SC & II & III \\
\hline SIMAZINAX SC & IV & IV \\
\hline SINBAR 800 & IV & IV \\
\hline SIPAZINA 800 PM & IV & IV \\
\hline \multicolumn{3}{|l|}{ SIPCAMOIL } \\
\hline SIPCATIN 500 SC & 11 & III \\
\hline SIPTRAN 500 SC & III & IV \\
\hline SOLVIREX $250 \mathrm{CE}$ & 1 & 1 \\
\hline SOLVIREX GR 100 & 1 & II \\
\hline SOLVIREX GR 50 & 1 & III \\
\hline SPARK CE & III & IV \\
\hline STAM 360 & III & IV \\
\hline STAM 480 & III & IV \\
\hline STAM BR & III & IV \\
\hline STARON SC & III & IV \\
\hline STAUZINA 500 SC & III & IV \\
\hline STAUZINA 800 PM & IV & IV \\
\hline \multicolumn{3}{|l|}{ STIRRUP M } \\
\hline SULFICAMP & IV & IV \\
\hline SUMICIDIN 10 UBV & IV & IV \\
\hline SUMICIDIN 200 & III & IV \\
\hline SUMICIDIN 25 UBV & IV & IV \\
\hline SUMI-EIGHT PM & IV & IV \\
\hline SUMIFOG & III & IV \\
\hline SUMIFOG 70 & IV & IV \\
\hline SUMITHION 400 PM & III & IV \\
\hline SUMITHION 500 CE & 11 & III \\
\hline SUPPORT & IV & IV \\
\hline SUPRACID $400 \mathrm{CE}$ & 1 & II \\
\hline SUPRATHION FERSOL $400 \mathrm{CE}$ & 1 & II \\
\hline SURCOPUR & III & IV \\
\hline SURFLAN 480 & IV & IV \\
\hline SURFLAN 750 BR & IV & IV \\
\hline
\end{tabular}


(continuação do Anexo III)

\begin{tabular}{|c|c|c|}
\hline PRODUTOS COMERCIAIS & CT80E & CT92E \\
\hline SUTAN $720 \mathrm{CE}$ & III & IV \\
\hline SUTAZIN $576+144$ SC & III & IV \\
\hline SWINGTOX MALATOL & III & IV \\
\hline \multicolumn{3}{|l|}{ TACKLE 170} \\
\hline TALCORD $250 \mathrm{CE}$ & II & III \\
\hline TALSTAR $100 \mathrm{CE}$ & II & III \\
\hline TAMARON BR & 1 & II \\
\hline TANGER & III & IV \\
\hline TECTO 100 & IV & IV \\
\hline TECTO 450 & IV & IV \\
\hline TECTO 600 & IV & IV \\
\hline TEDION 80 & IV & IV \\
\hline TEMIK 150 & 1 & II \\
\hline \multicolumn{3}{|l|}{ TERMAZOL } \\
\hline TERRACLOR 750 PM BR UNIROYAL & IV & IV \\
\hline TERRACOAT UNIROYAL & IV & IV \\
\hline TERRAZOLE 350 PM & IV & IV \\
\hline \multicolumn{3}{|l|}{ THIOBEL 500} \\
\hline THIODAN $20 \mathrm{P}$ & IV & IV \\
\hline THIODAN $30 \mathrm{P}$ & IV & IV \\
\hline THIODAN $500 \mathrm{SC}$ & 1 & II \\
\hline THIODAN CE & II & III \\
\hline THIODAN SC & II & III \\
\hline THIODAN UBV & II & III \\
\hline THIOVIT & IV & IV \\
\hline THIOVIT $800 \mathrm{SC}$ & III & IV \\
\hline \multicolumn{3}{|l|}{ THURICIDE } \\
\hline TIFON $250 \mathrm{SC}$ & II & III \\
\hline TILT & IV & IV \\
\hline TIOFANIL & IV & IV \\
\hline TIOMET $400 \mathrm{CE}$ & II & III \\
\hline TOPEZE & IV & IV \\
\hline TOPEZE SC & III & IV \\
\hline TORDON $10 \mathrm{GR}$ & IV & IV \\
\hline TORDON 2,4-D 64/240 TRIETANOLAMINA BR & 11 & III \\
\hline TORQUE 500 SC & III & IV \\
\hline TOTRIL & II & III \\
\hline TREFLAN & IV & IV \\
\hline TRIAMEX $500 \mathrm{SC}$ & III & IV \\
\hline TRIBAN & III & IV \\
\hline TRICLORFON 500 DEFENSA & II & III \\
\hline
\end{tabular}


(final do Anexo III)

\begin{tabular}{|l|c|c|}
\hline PRODUTOS COMERCIAIS & CT80E & CT92E \\
\hline TRICLORFON 800 PS DEFENSA & III & IV \\
\hline TRIFLURALINA DEFENSA & IV & IV \\
\hline TRIFLURALINA GR NORTOX & IV & IV \\
\hline TRIFLURALINA HOECHST & IV & IV \\
\hline TRIFLURALINA NORTOX & IV & IV \\
\hline TRIGARD 750 PM & IV & IV \\
\hline TRIONA & IV & IV \\
\hline TRITAC & IV & IV \\
\hline TROPAZIN & II & III \\
\hline TUFORDON & II & III \\
\hline U 46 COMBI FLUID 550 & II & III \\
\hline U 46 D FLUID 2,4-D & II & III \\
\hline U 46 D-ESTER & II & III \\
\hline U 46 M FLUID 625 MCPA & IV & IV \\
\hline UNDEN PO & II & III \\
\hline VALON 384 CE & IV & IV \\
\hline VANOX 500 SC & IV & IV \\
\hline VANOX 750 PM & IV & IV \\
\hline VELPAR K & IV & IV \\
\hline VELPAR K-GRDA & III & IV \\
\hline VENTUROL & $\cdot$ &. \\
\hline VERDICT & III & IV \\
\hline VERNAM 720 CE & $\cdot$ &. \\
\hline VERTIMEC 18 CE & III & IV \\
\hline VETRAN & III & IV \\
\hline VIRICOBRE PM & III & IV \\
\hline VITAVAX - THIRAM PM UNIROYAL & IV & IV \\
\hline VITAVAX 750 PM BR & $\cdot$ & $\cdot$ \\
\hline VITIGRAN AZUL BR & II & III \\
\hline VITIGRAN VERDE BR & II & III \\
\hline ZOLONE 350 CE & \\
\hline ZOLONE UBV & & \\
\hline
\end{tabular}




\section{ANEXO 4 - banco de dados no 5 - produtos registrados para controle do "pulgão do algodoeiro" (Aphis gossypii)}

\section{LEGENDA:}

PC1990 (confirma registro do produto comercial em 1990): Y - Sim ; N - Não

PC2000 (confirma registro do produto comercial em 2000): Y - Sim ; N - Não

IA1990 (confirma registro do ingrediente ativo em 1990): $\mathrm{Y}-\mathrm{Sim} ; \mathrm{N}-\mathrm{Não}$

IA2000 (confirma registro do ingrediente ativo em 2000): $\mathrm{Y}-\mathrm{Sim} ; \mathrm{N}$ - Não

CT1990 (Classe Toxicológica em 1990 - referente à Portaria DISAD nº 4/80):

I - altamente tóxico ; II - medianamente tóxico ; III - pouco tóxico ;

IV - praticamente não tóxico;

CT2000 (Classe Toxicológica em 2000 - referente à Portaria SNVS nº 3/92):

I - extremamente tóxico ; II - altamente tóxico ;

III - medianamente tóxico; IV - pouco tóxico;

\begin{tabular}{|c|c|c|c|c|c|c|}
\hline PRODUTO COMERCIAL & PC1990 & PC2000 & IA1990 & IA200 & CT1990 & CT2000 \\
\hline ACEFATO FERSOL 750 PS & $Y$ & $\mathrm{Y}$ & $\mathrm{Y}$ & $\mathrm{Y}$ & III & IV \\
\hline ACTARA 250 WG & $\mathrm{N}$ & Y & $\mathrm{N}$ & $\mathrm{Y}$ & & III \\
\hline AGRITOATO 400 & $\mathrm{~N}$ & $Y$ & Y & Y & & 1 \\
\hline AGROPHOS 400 & $\mathrm{~N}$ & $\mathrm{Y}$ & $\mathrm{Y}$ & $\mathrm{Y}$ & & 1 \\
\hline AMBUSH $500 \mathrm{CE}$ & $\mathrm{Y}$ & $Y$ & $Y$ & $Y$ & II & \\
\hline ARRIVO $200 \mathrm{CE}$ & $Y$ & $\mathrm{Y}$ & $\mathrm{Y}$ & $\mathrm{Y}$ & II & . \\
\hline AZODRIN 400 & $\mathrm{Y}$ & $\mathrm{Y}$ & Y & Y & 1 & 1 \\
\hline AZODRIN 75 UBV & $\bar{Y}$ & Y & $\mathrm{Y}$ & Y & 1 & 1 \\
\hline BAYTROID CE & $Y$ & $Y$ & $Y$ & Y & 1 & \\
\hline BELMARK 75 CE & $\mathrm{Y}$ & $Y$ & $\mathrm{Y}$ & Y & I & 1 \\
\hline BRAVIK $600 \mathrm{CE}$ & $\mathrm{N}$ & $\mathrm{Y}$ & $\mathrm{Y}$ & $\mathrm{Y}$ & ${ }^{2}$ & 1 \\
\hline BULLDOCK 125 SC & $N$ & $Y$ & $N$ & $Y$ &. & 11 \\
\hline CARBARYL FERSOL $50 \mathrm{P}$ & $\mathrm{Y}$ & $\mathrm{N}$ & $\mathrm{Y}$ & $\mathrm{Y}$ & III & 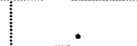 \\
\hline CARBOFURAN SANACHEM 350 TS & $\mathrm{N}$ & $\mathrm{Y}$ & $\mathrm{Y}$ & $\mathrm{Y}$ & & 1 \\
\hline CEFANOL & $Y$ & $Y$ & $Y$ & $\mathrm{Y}$ & III & \\
\hline COMMANCHE $200 \mathrm{CE}$ & $\mathrm{N}$ & $\mathrm{Y}$ & $\mathrm{Y}$ & $Y$ &. & III \\
\hline CONFIDOR 700 GRDA & $N$ & $Y$ & $N$ & $Y$ & & IV \\
\hline
\end{tabular}


(continuação do Anexo IV)

\begin{tabular}{|c|c|c|c|c|c|c|}
\hline $\mathrm{PC}$ & PC1990 & PC2000 & IA1990 & IA2000 & CT1990 & CT2000 \\
\hline COUNTER $50 \mathrm{G}$ & $\mathrm{N}$ & $\mathrm{Y}$ & $\mathrm{N}$ & $Y$ & . & 1 \\
\hline CRUISER $700 \mathrm{WS}$ & $N$ & $Y$ & $\mathrm{~N}$ & $Y$ & . & III \\
\hline CURINGA & $N$ & $Y$ & $Y$ & $Y$ & 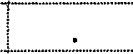 & III \\
\hline CYMBUSH 250 CE & $Y$ & $\mathrm{Y}$ & $\mathrm{Y}$ & $Y$ & II & II \\
\hline CYPTRIN $250 \mathrm{CE}$ & $\mathrm{N}$ & $\mathrm{Y}$ & $Y$ & $\mathrm{Y}$ & & 1 \\
\hline CYTHION 1000 & $\mathrm{Y}$ & $\mathrm{N}$ & $\mathrm{Y}$ & $\mathrm{Y}$ & II & \\
\hline DDVP 1000 CE DEFENSA & $\mathrm{Y}$ & $\mathrm{Y}$ & $\mathrm{Y}$ & $\mathrm{Y}$ & 1 & 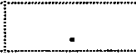 \\
\hline DDVP 500 CE CALAIS & $Y$ & $N$ & $Y$ & $\underline{Y}$ & 1 & . \\
\hline DDVP 500 CE DEFENSA & $\mathrm{Y}$ & $\mathrm{Y}$ & $Y$ & $\mathrm{Y}$ & 1 & 1 \\
\hline DECIS 25 CE & $Y$ & $Y$ & $Y$ & $\mathrm{Y}$ & II & II \\
\hline DECIS 4 UBV & $Y$ & $Y$ & $Y$ & $\mathrm{Y}$ & III & III \\
\hline DIAFURAN 50 & $Y$ & Y & $Y$ & $Y$ & 1 & \\
\hline DIMECRON 500 & $Y$ & $Y$ & $Y$ & $Y$ & 1 & 1 \\
\hline DIMETOATO 500 CE NORTOX & $\mathrm{Y}$ & $\mathrm{N}$ & $Y$ & $\mathrm{Y}$ & 1 & \\
\hline DIMETOATO CE & $Y$ & $Y$ & $Y$ & $Y$ & 1 & II \\
\hline DIMEXION & $Y$ & Y & $Y$ & Y & 1 & II \\
\hline DISSULFAN CE & $Y$ & $Y$ & $Y$ & $Y$ & 1 & \\
\hline DISSULFAN UBV & $Y$ & $Y$ & Y & Y & 1 & 1 \\
\hline DISYSTON GR 50 & $Y$ & $\mathrm{~N}$ & $Y$ & $Y$ & 1 & \\
\hline EKATIN & $\mathrm{Y}$ & Y & $Y$ & $Y$ & II & III \\
\hline ENDOSULFAN 350 CE DEFENSA & Y & Y & Y & Y & 1 & \\
\hline ENDOSULFAN AG & $\mathrm{N}$ & $Y$ & $Y$ & $\bar{Y}$ & & II \\
\hline FENVALERATE 200 CE DEFENSA & Y & $Y$ & $Y$ & Y & 1 & II \\
\hline FOLIDOL 600 & $Y$ & $\mathrm{~N}$ & Y & Y & 1 & . \\
\hline FOLIMAT 1000 & $Y$ & $N$ & $\mathrm{Y}$ & Y & 1 & . \\
\hline FOLISUPER $600 \mathrm{BR}$ & $\mathrm{N}$ & Y & Y & $\mathrm{Y}$ & $=$ & 1 \\
\hline FRUMIN & $Y$ & $Y$ & $Y$ & $Y$ & 1 & 1 \\
\hline FURADAN $100 \mathrm{G}$ & $\mathrm{N}$ & Y & Y & Y & . & 1 \\
\hline FURADAN 350 SC & $Y$ & $Y$ & $Y$ & $Y$ & 1 & 1 \\
\hline FURADAN 350 TS & Y & $Y$ & Y & $Y$ & 1 & 1 \\
\hline FURADAN $50 \mathrm{G}$ & $Y$ & $Y$ & $Y$ & $Y$ & 1 & 1 \\
\hline FURY $180 \mathrm{EW}$ & $N$ & $Y$ & $N$ & $Y$ & . & II \\
\hline GAUCHO & $\mathrm{N}$ & $Y$ & $N$ & $Y$ & & IV \\
\hline GRANUTOX & $Y$ & $Y$ & $Y$ & $Y$ & 1 & 1 \\
\hline GRANUTOX $150 \mathrm{G}$ & $N$ & $Y$ & $Y$ & $Y$ & $\cdot$ & II \\
\hline GUSATHION 400 & $Y$ & $N$ & $Y$ & $Y$ & 1 & 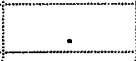 \\
\hline HAMIDOP 600 & $N$ & $Y$ & $Y$ & $Y$ & & 1 \\
\hline HOSTATHION 400 BR & $Y$ & Y & $Y$ & $Y$ & 1 & 1 \\
\hline HARA DIMETHOATE 500 & $Y$ & $\mathrm{~N}$ & $Y$ & $Y$ & 1 & \\
\hline KILVAL 300 & $Y$ & Y & $Y$ & Y & II & III \\
\hline LANNATE BR & $Y$ & $Y$ & $Y$ & $Y$ & 1 &. \\
\hline
\end{tabular}


(continuação do Anexo IV)

\begin{tabular}{|c|c|c|c|c|c|c|}
\hline $\mathrm{PC}$ & PC1990 & PC2000 & IA1990 & IA2000 & CT1990 & CT2000 \\
\hline LEBAYCID 500 & $\mathrm{Y}$ & $\bar{Y}$ & $\mathrm{Y}$ & $\mathrm{Y}$ & II & \\
\hline LORSBAN 480 BR & $\mathrm{Y}$ & $Y$ & Y & $Y$ & II & II \\
\hline MALATHION 500 CE PIKAPAU & $\mathrm{N}$ & $\mathrm{Y}$ & $\mathrm{Y}$ & $\mathrm{Y}$ & & IIII \\
\hline MALATHION 500 CE SULTOX & $\mathrm{Y}$ & Y & Y & $\mathrm{Y}$ & IIII & \\
\hline MALATOL $1000 \mathrm{CE}$ & $\mathrm{Y}$ & Y & $\mathrm{Y}$ & $\mathrm{Y}$ & II & II \\
\hline MALATOL $250 \mathrm{PM}$ & $\mathrm{Y}$ & $\mathrm{N}$ & Y & Y & III & \\
\hline MALATOL $40 \mathrm{P}$ & $\mathrm{Y}$ & $\mathrm{Y}$ & $\mathrm{Y}$ & $\mathrm{Y}$ & III & IV \\
\hline MALATOL 500 CE & $\mathrm{Y}$ & $\mathrm{Y}$ & $\mathrm{Y}$ & $\mathrm{Y}$ & III & III \\
\hline MALATOL UBV & $\mathrm{Y}$ & Y & Y & $\mathrm{Y}$ & III & III \\
\hline MARSHAL $200 \mathrm{SC}$ & $\mathrm{N}$ & Y & Y & Y & & II \\
\hline MARSHAL 250 TS & Y & $\mathrm{N}$ & $\mathrm{Y}$ & $\mathrm{Y}$ & II & \\
\hline MARSHAL 350 TS & Y & Y & Y & $\mathrm{Y}$ & II & II \\
\hline MENTOX $600 \mathrm{CE}$ & $\mathrm{N}$ & Y & Y & $\mathrm{Y}$ &. & 1 \\
\hline METAFOS & $\mathrm{N}$ & Y & Y & $\mathrm{Y}$ & . & 1 \\
\hline METAMIDOFOS 600 DEFENSA & Y & Y & Y & Y & 1 & \\
\hline METAMIDOFOS FERSOL 600 & $N$ & Y & $\mathrm{Y}$ & $\mathrm{Y}$ & $\cdot$ & II \\
\hline METASIP & $\mathrm{N}$ & $\mathrm{Y}$ & $Y$ & Y &. & 1 \\
\hline METASYSTOX (I) CE 250 & Y & $\mathrm{N}$ & Y & Y & 1 &. \\
\hline METHIL PARATHION 600 CE INSETICIDA A & $Y$ & $Y$ & Y & Y & 1 & 1 \\
\hline METHOMEX 215 LS & $\mathbf{N}$ & Y & Y & $\mathrm{Y}$ &. & II \\
\hline MOSPILAN & $\mathrm{N}$ & $Y$ & $N$ & $Y$ &. & III \\
\hline NALED 860 & $\mathrm{~N}$ & $Y$ & Y & Y & & II \\
\hline NOR-TRIN $250 \mathrm{CE}$ & $Y$ & $Y$ & $Y$ & $\mathrm{Y}$ & 11 & $\cdot$ \\
\hline NURELLE $250 \mathrm{CE}$ & Y & $\mathrm{N}$ & $\mathrm{Y}$ & $Y$ & II & $\cdot$ \\
\hline NUVACRON 400 & Y & $Y$ & $Y$ & $Y$ & 1 & \\
\hline ONCOL SIPCAM & $\mathrm{N}$ & $Y$ & $N$ & Y & & 11 \\
\hline ORTHENE $750 \mathrm{BR}$ & $Y$ & $Y$ & $Y$ & $Y$ & III & IV \\
\hline ORTHO HAMIDOP 600 & Y & Y & $\mathrm{Y}$ & $Y$ & 1 & .. \\
\hline ORTHO NALED 860 & Y & Y & $Y$ & $Y$ & 11 & 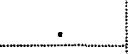 \\
\hline PERFEKTHION & Y & Y & Y & Y & 1 &. \\
\hline POLO 500 PM & $\mathrm{N}$ & Y & $\mathrm{N}$ & $Y$ & & 1 \\
\hline POSSE 200 ED BICO BRANCO & Y & $N$ & Y & $\bar{Y}$ & II &. \\
\hline POUNCE 384 CE & Y & Y & Y & $Y$ & II & 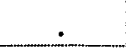 \\
\hline PROMET $400 \mathrm{CS}$ & $\mathrm{N}$ & $\mathrm{Y}$ & Y & Y & $\cdot$ & III \\
\hline PROVADO & $N$ & Y & $\mathrm{N}$ & Y &. & IV \\
\hline RALZER 50 GR & Y & $Y$ & Y & $\mathrm{Y}$ & 1 &. \\
\hline SAURUS & $\mathrm{N}$ & Y & $\mathrm{N}$ & Y & 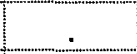 & III \\
\hline SHERPA 200 & $\mathrm{~N}$ & $Y$ & $\mathrm{Y}$ & $\mathrm{Y}$ & . & II \\
\hline SOLVIREX GR 100 & $Y$ & $\mathrm{Y}$ & $Y$ & $Y$ & 1 & III \\
\hline SOLVIREX GR 50 & Y & $\mathrm{N}$ & $\mathrm{Y}$ & $\mathrm{Y}$ & 1 & \\
\hline STRON & $\mathrm{N}$ & $Y$ & Y & $Y$ & -5 & 1 \\
\hline
\end{tabular}


(final do Anexo IV)

\begin{tabular}{|c|c|c|c|c|c|c|}
\hline PC & PC1990 & PC2000 & IA1990 & $1 \mathrm{~A} 200$ & CT19 & CT2000 \\
\hline SUMICIDIN 200 & $Y$ & $\mathrm{Y}$ & $\mathrm{Y}$ & $\mathrm{Y}$ & II & \\
\hline SUMICIDIN 25 UBV & $Y$ & Y & $Y$ & $Y$ & II & \\
\hline SUMIDAN $25 \mathrm{CE}$ & $N$ & $Y$ & $N$ & $Y$ & & 1 \\
\hline SUMITHION 400 PM & $Y$ & $Y$ & $Y$ & $Y$ & II & \\
\hline SUMITHION $500 \mathrm{CE}$ & $Y$ & $Y$ & $Y$ & $Y$ & 11 & \\
\hline SUMITHION UBV & $\mathrm{N}$ & $Y$ & $Y$ & $Y$ &. & II \\
\hline TAMARON BR & $Y$ & $Y$ & $Y$ & $Y$ & 1 & II \\
\hline TEMIK 100 & $N$ & $Y$ & $Y$ & $Y$ &. & 1 \\
\hline TEMIK 150 & $Y$ & $Y$ & $Y$ & $Y$ & 1 & \\
\hline THIODAN $30 \mathrm{P}$ & $Y$ & $Y$ & $Y$ & $Y$ & III & III \\
\hline THIODAN CE & $Y$ & $Y$ & $Y$ & $Y$ & 1 & II \\
\hline TIOMET $400 \mathrm{CE}$ & $Y$ & $Y$ & $Y$ & $Y$ & 1 & \\
\hline TOKUTHION 500 CE & $\mathrm{N}$ & $Y$ & $\mathrm{~N}$ & Y &. & II \\
\hline UNDEN PO & $Y$ & $\mathrm{~N}$ & $Y$ & $Y$ & III & \\
\hline VALON $384 \mathrm{CE}$ & $Y$ & $Y$ & $Y$ & $Y$ & II & \\
\hline VEXTER & $\mathrm{N}$ & $Y$ & $\mathrm{Y}$ & $Y$ & . & II \\
\hline ZOLONE $350 \mathrm{CE}$ & $Y$ & $\mathrm{~N}$ & $Y$ & $Y$ & II & \\
\hline ZOLONE UBV & $Y$ & $N$ & $Y$ & $Y$ & II & \\
\hline
\end{tabular}

